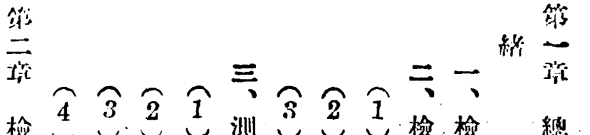

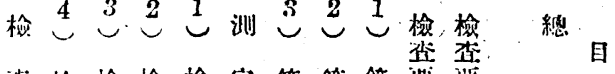

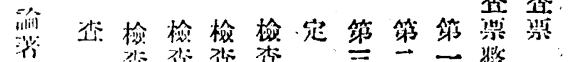

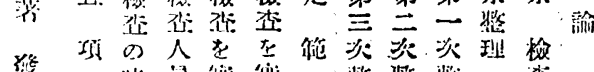

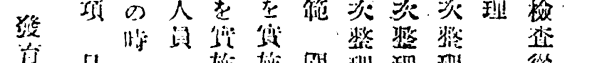

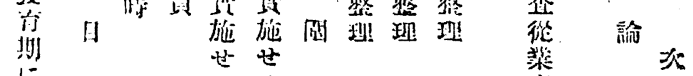
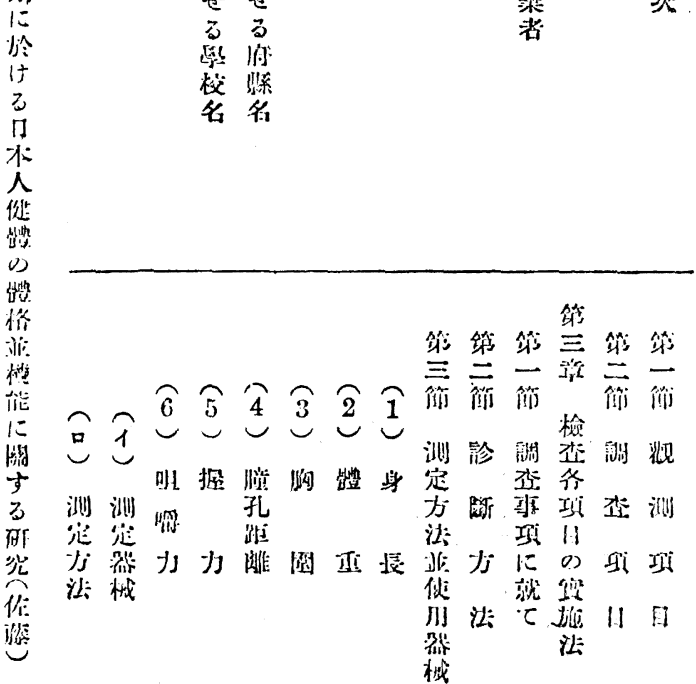

列 


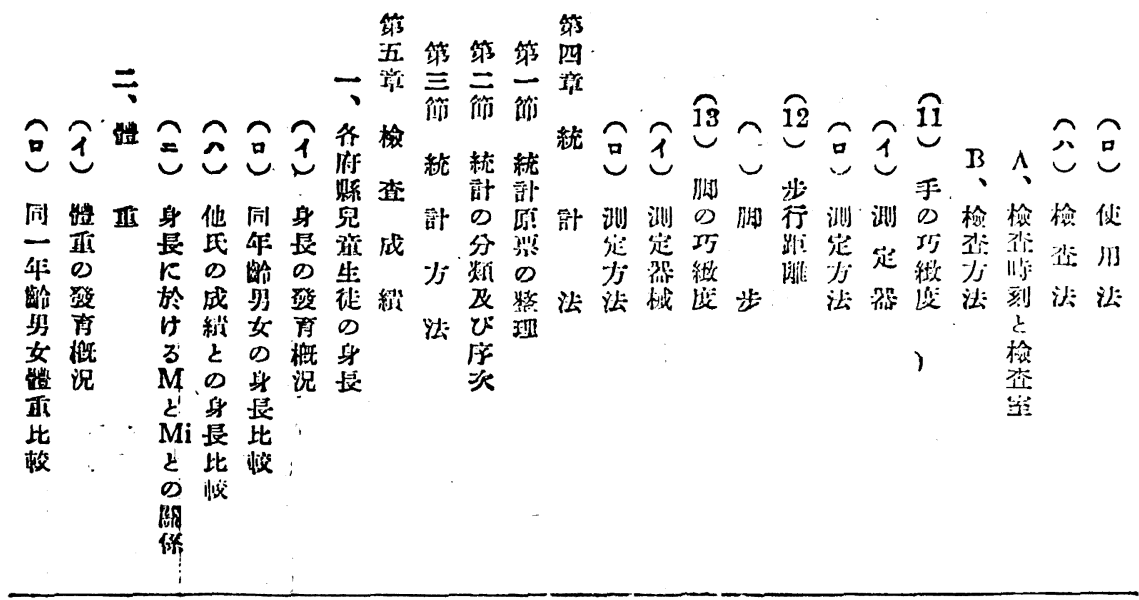

踊

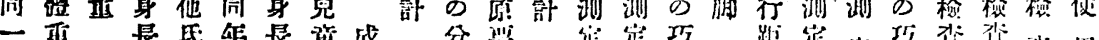

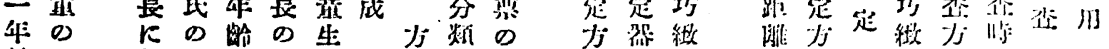

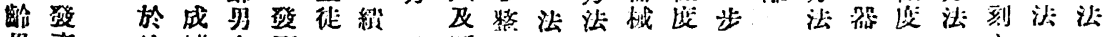

男者け釉女青の法び理

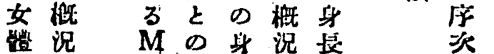

Mi 展 比

已 比恔

㬐

畒

架

(1)

日

㶱

侹

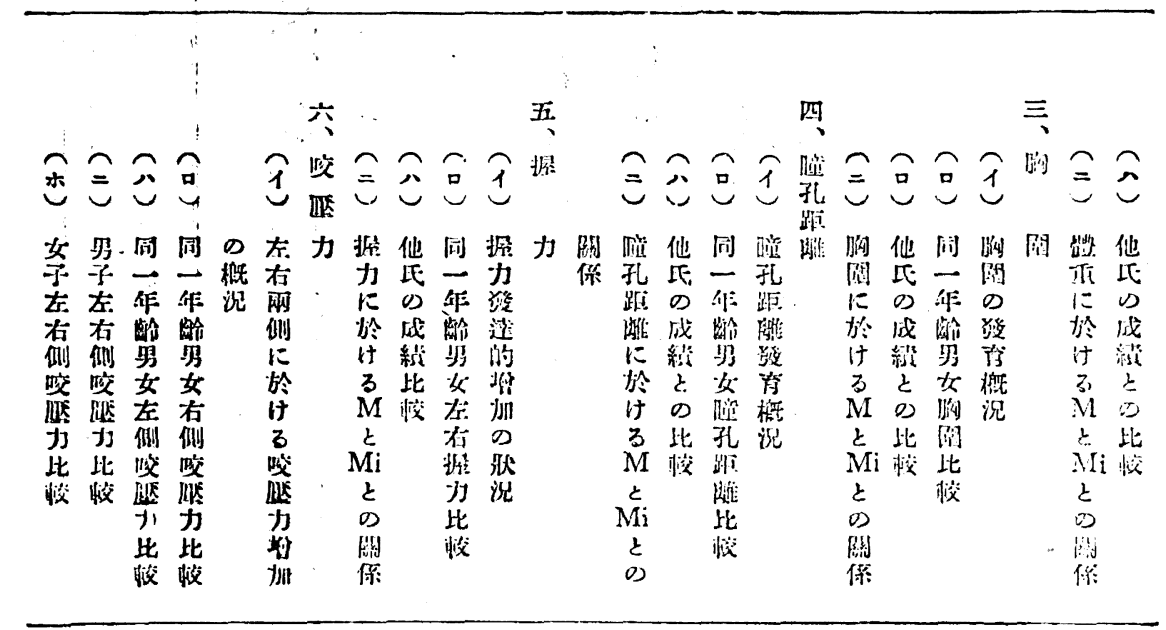

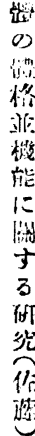

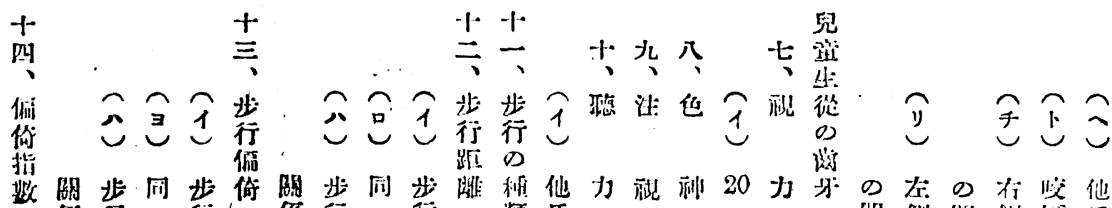

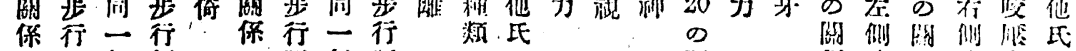

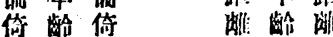

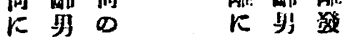

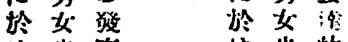

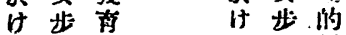

当行的行抬

3 何禁 $\mathrm{M}$ 距汌

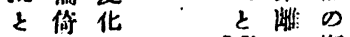

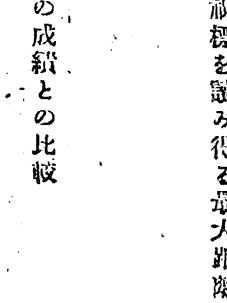

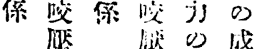

ㅁㄴ

Mi $の$ の

长比 概

Mi 少梅

の收涚

飞此況

备

力行絽

に

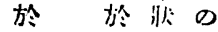

けけ掏咬

$\stackrel{3}{\mathrm{M}} \stackrel{3}{\mathrm{M}}$ 省

$\stackrel{2}{\mathrm{Mi}} \stackrel{2}{\mathrm{mi}}$ 椋 


\section{VI惢 10;}

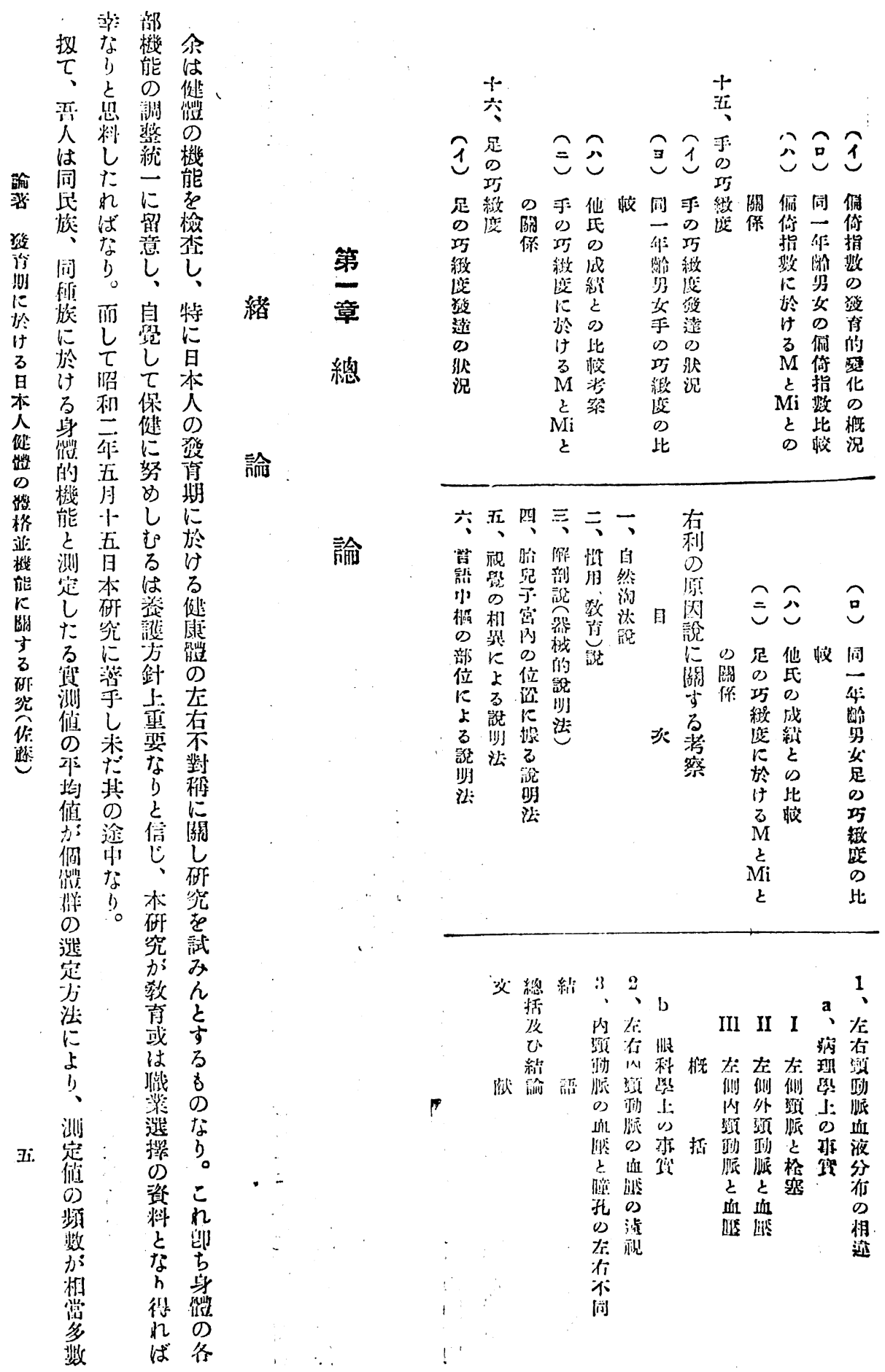


一镉

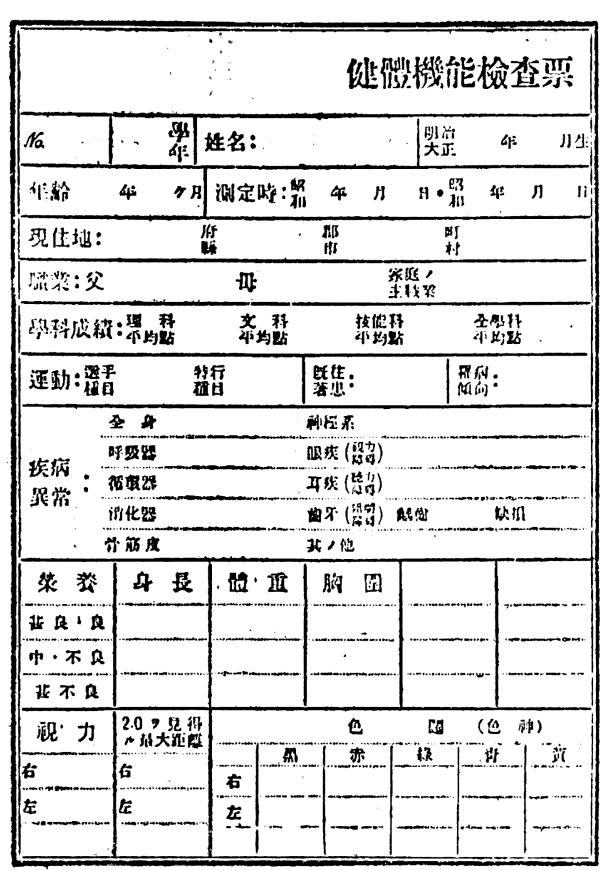

て 以な之悲余遵而

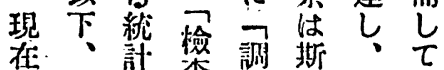
迄如法龺查の檢被

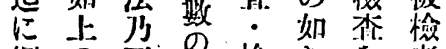

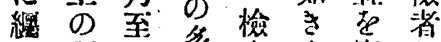

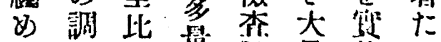

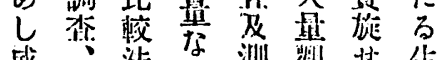

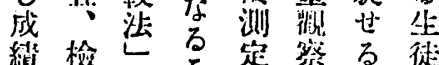

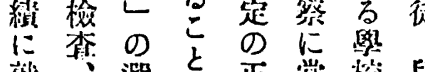

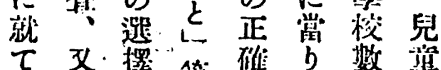

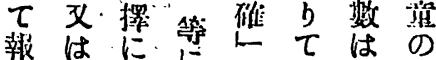
告 测努に一、一總

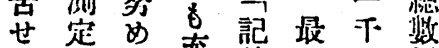

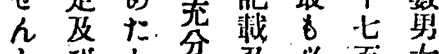
を恕。分文必百炎

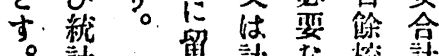

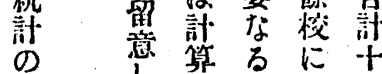

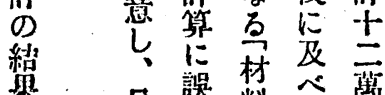

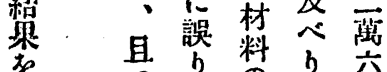

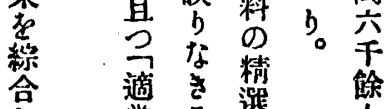

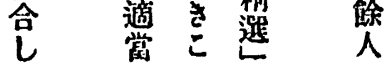

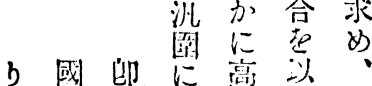
思似なへ非人施

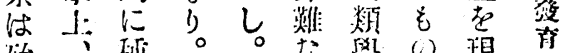

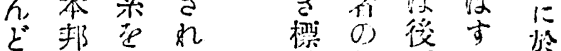

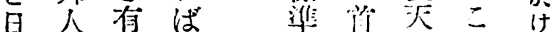

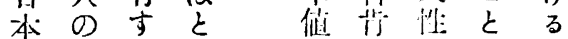

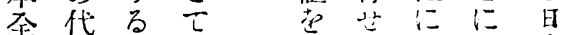

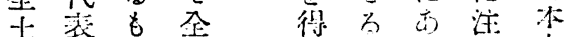

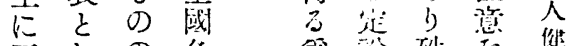

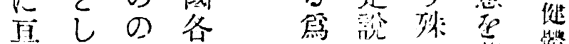

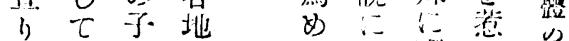

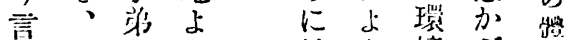
外天支地り境ざ格

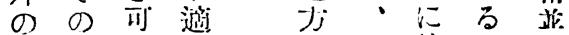

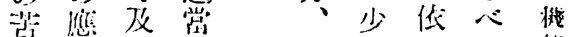
心用的な地人启市施

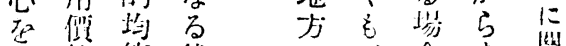

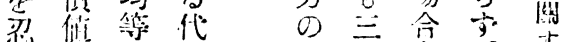
びのの表特和多。

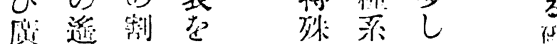
洮合求 0 占党 後尖倍裳 㤬 3 俆 儿北立各の影落

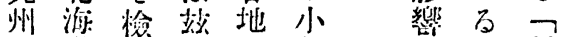

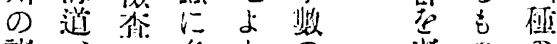

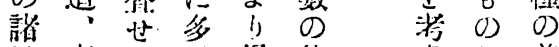

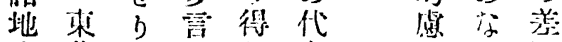
卢北。异た装 せ方心

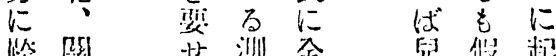

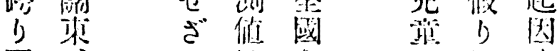

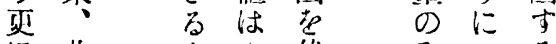
に北衣代み元

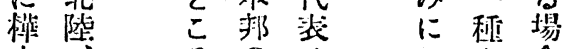
太方尔作せ 二 出意吉約定亦 部、手了古 に來他こ不吕な

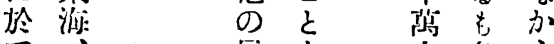

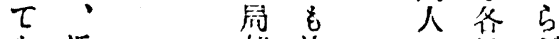
近部淌少地

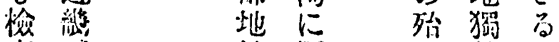
盗。域困特心 行國䄄篚茎外。 ひ我等间部因 た叫得题江市 


\section{VI㑻 107}

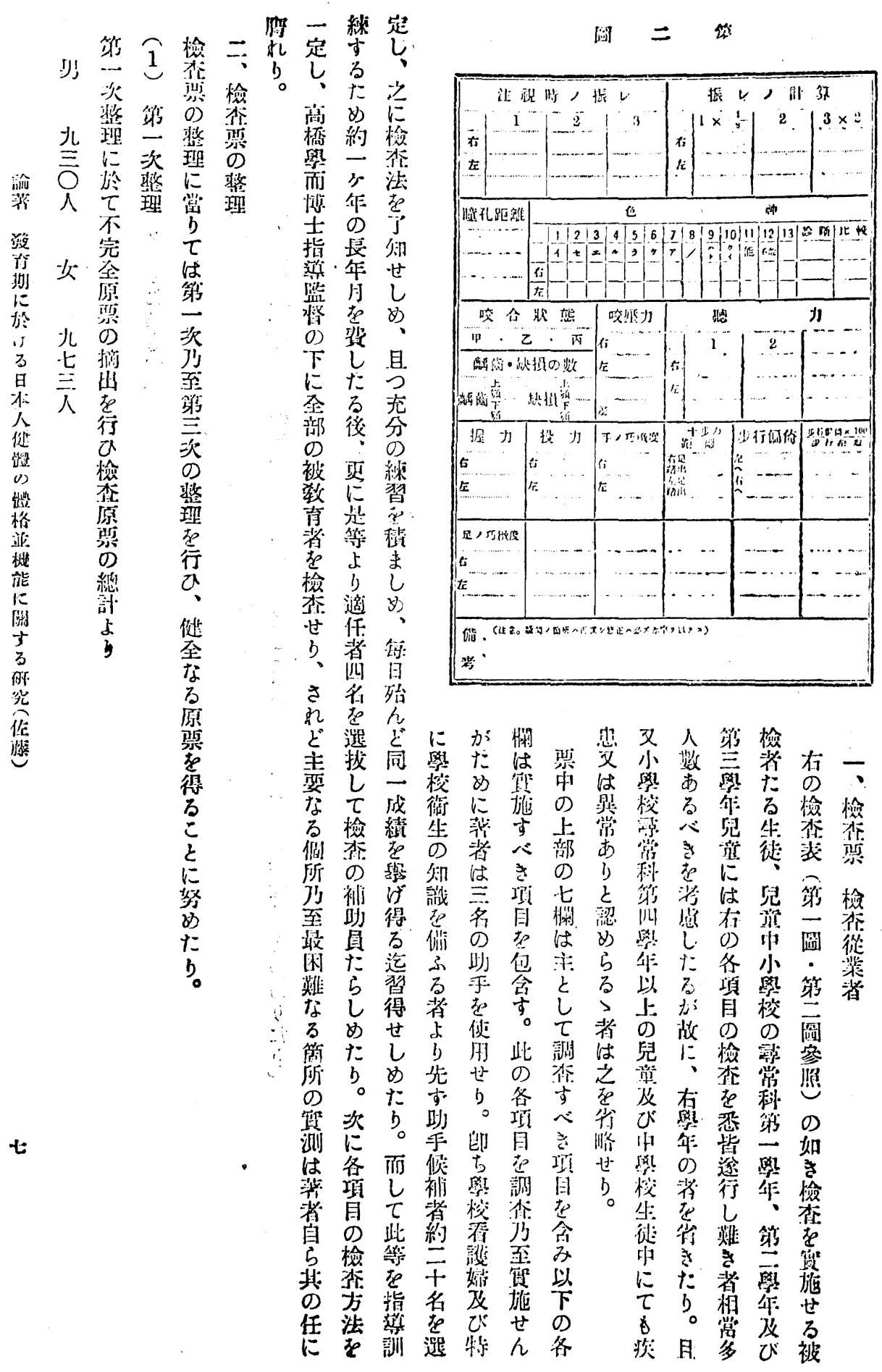


敄

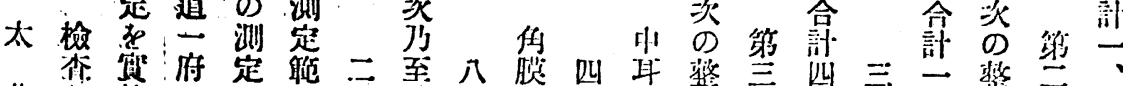

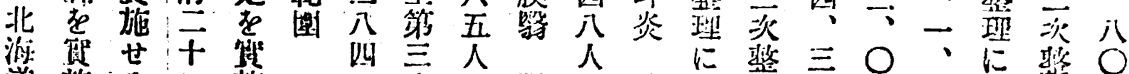

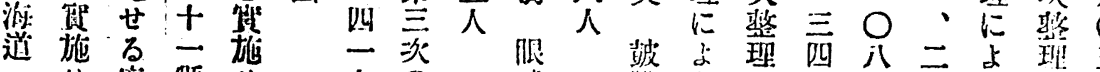

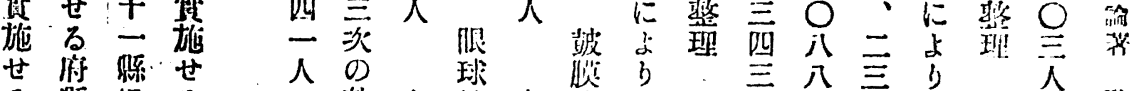

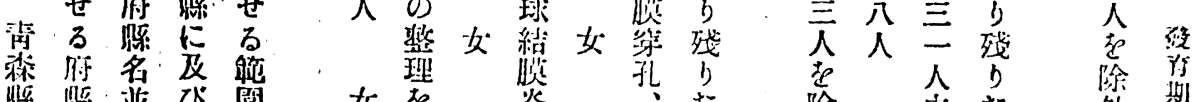

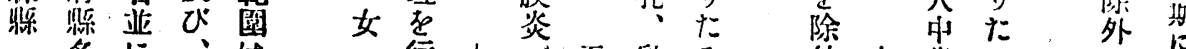

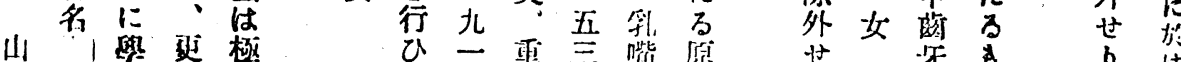

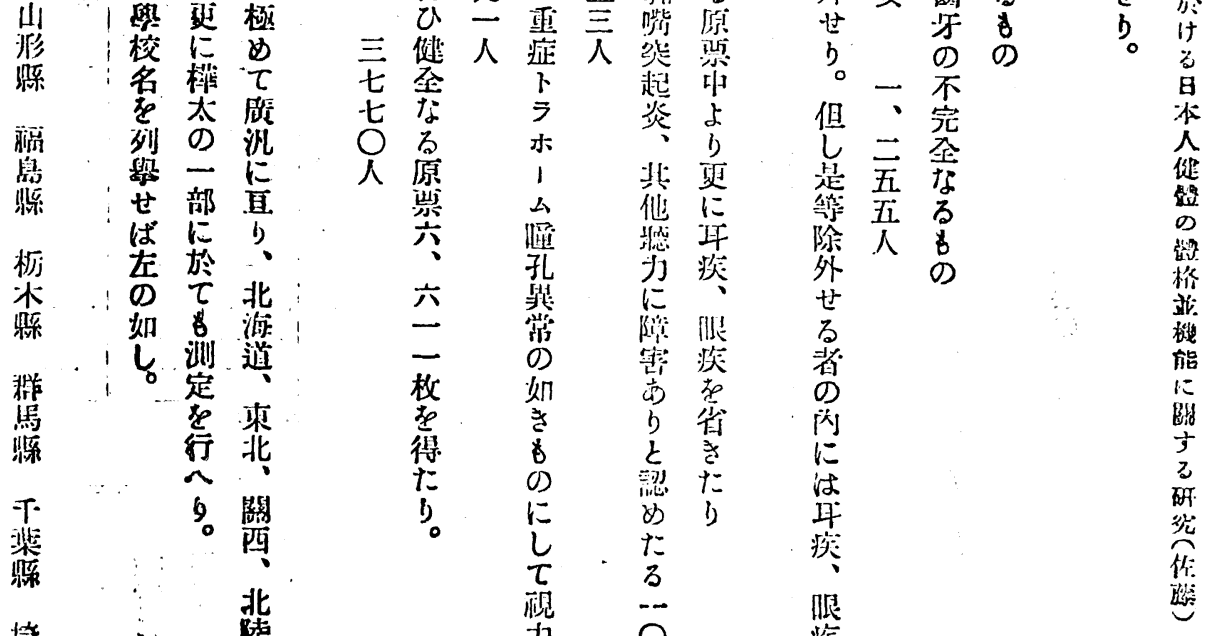
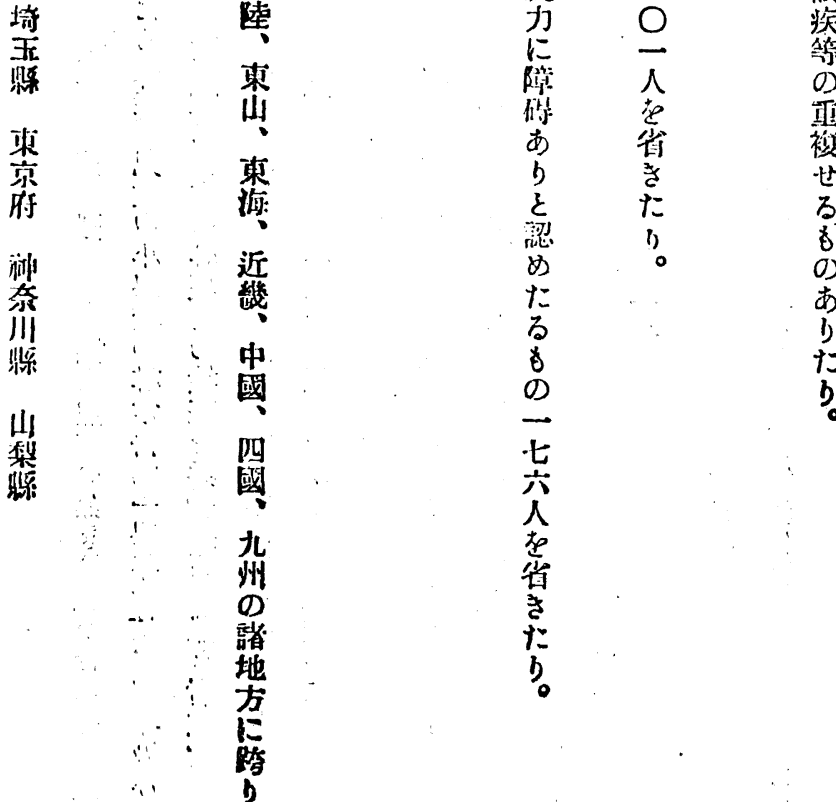

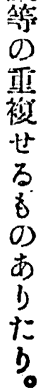

势

六 
䋧網宗等宗

走起谷谷

郡非 娜郡娜

縐約名名䄻

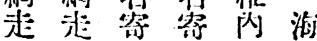

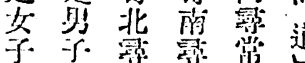

䟽

然

些

於

3

标

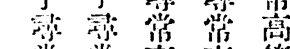

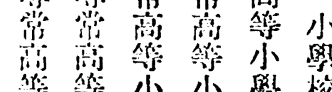

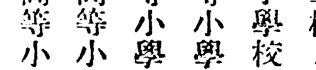

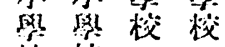

校 校

部

1

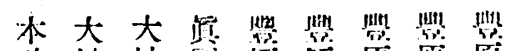

2

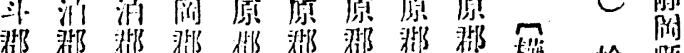

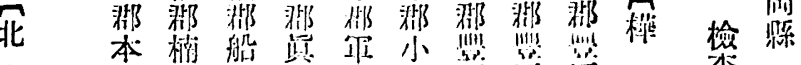

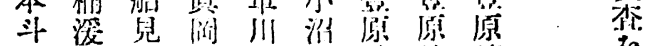

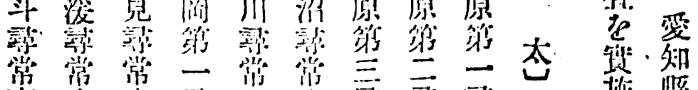

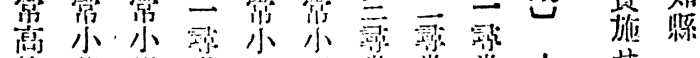

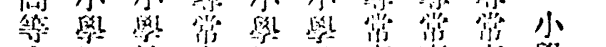

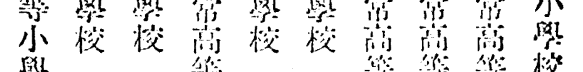
歌 校

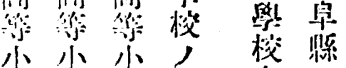

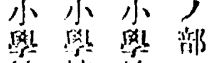
梲 校

校
せ

る 怶

名石

夘 川

船 步

せ

ば忿

灰 䇣

如

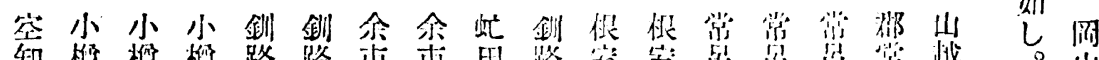

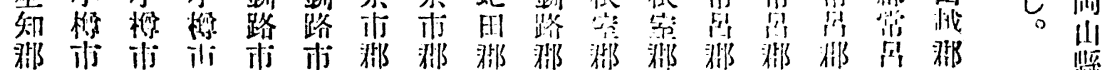

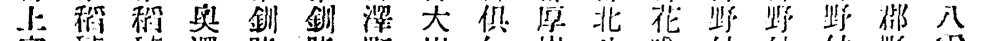

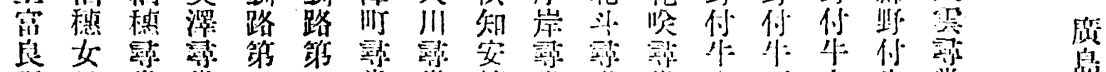

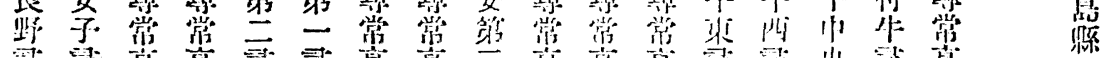

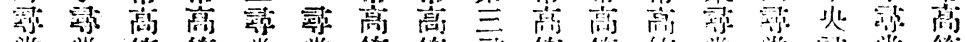

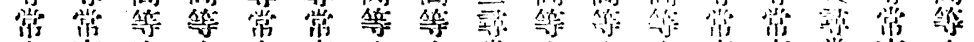

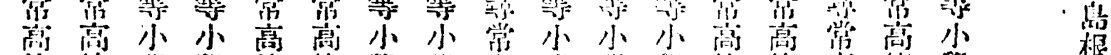

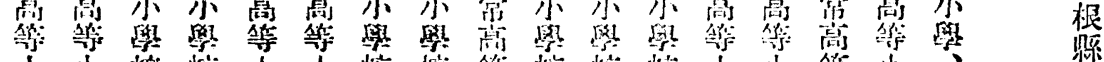

小小校校 小小校 校行校校校，小小行小

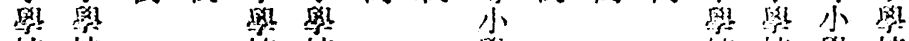

校 校

校 校

恔

校 校 霖 校

怒
嫒
踧

高

策

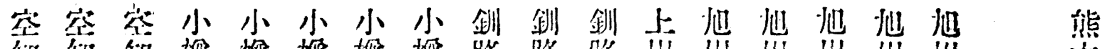

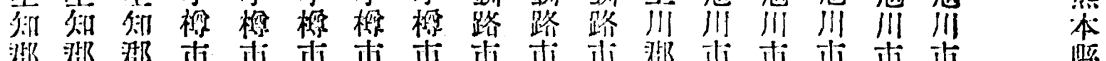

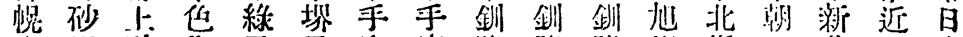

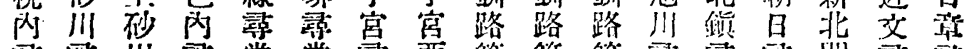

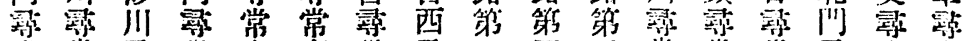

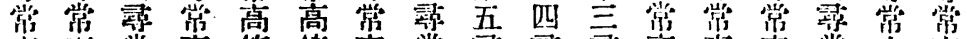

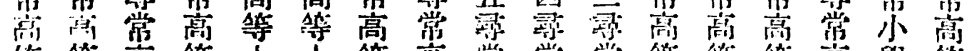

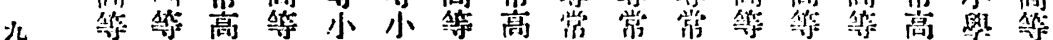

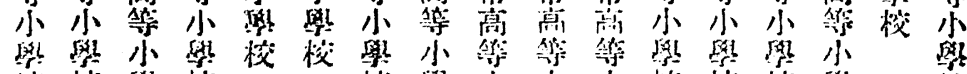
校 校 感校

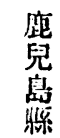


空宾宾網絀空空空紋紋炕夕夕夕夕夕空突挹

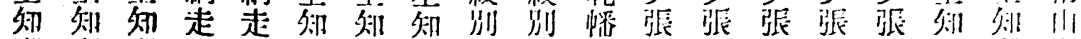

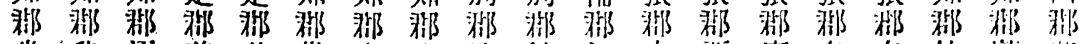

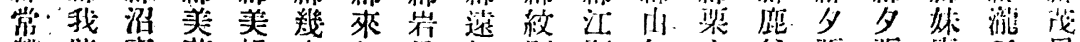

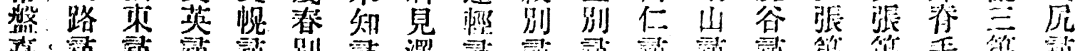

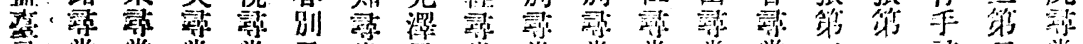

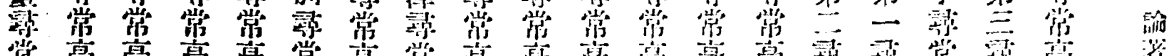

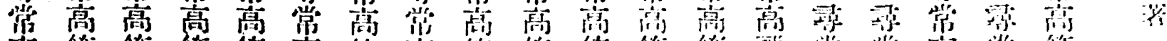

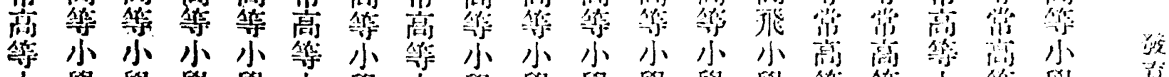

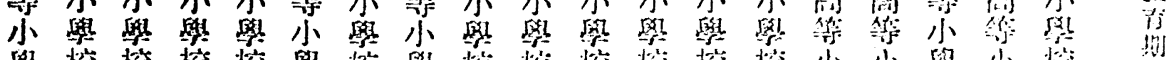

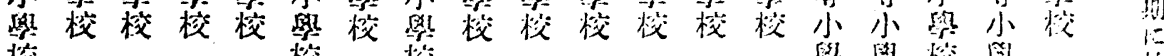

校

校 校 校

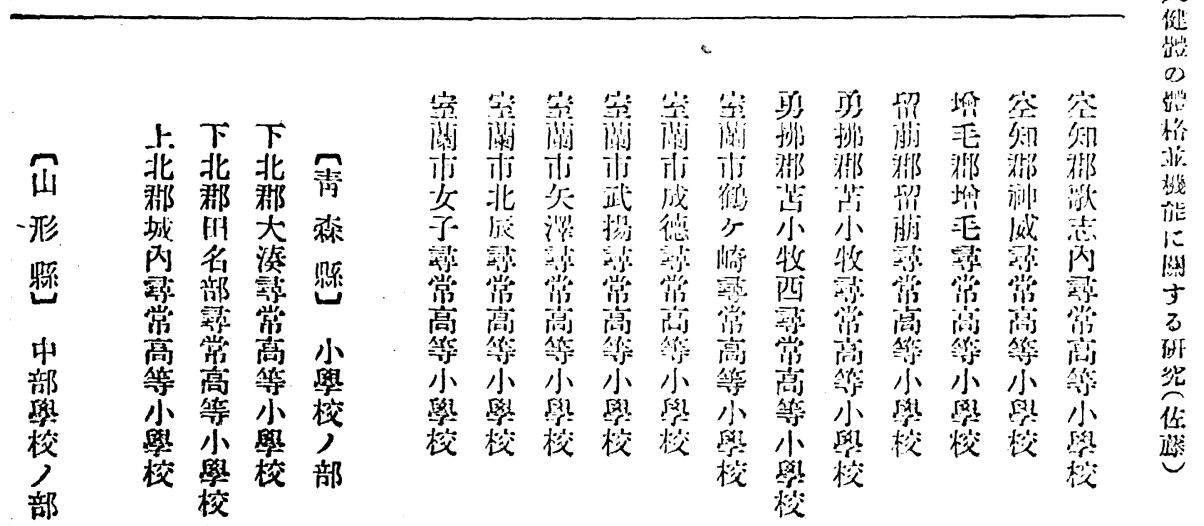

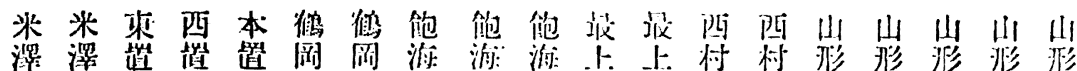

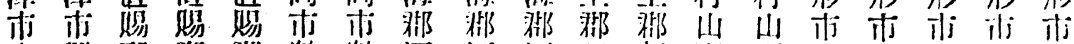

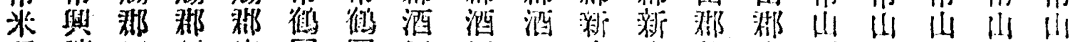

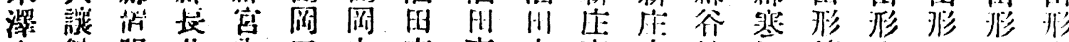

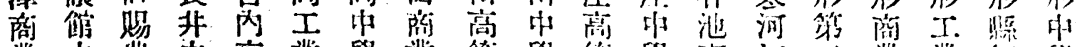

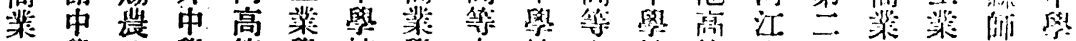

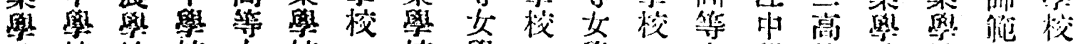

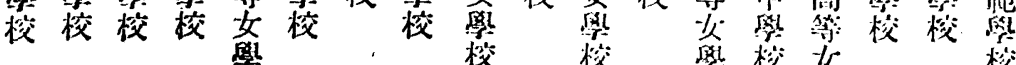

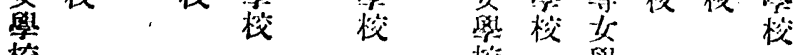


涌

倠

洺

人

濦

(1)

㥪

䍀

に

儑

5

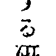

形

發

集

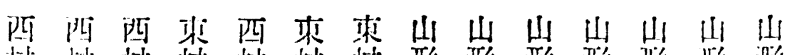

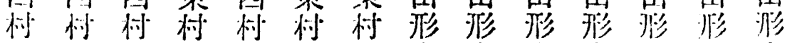

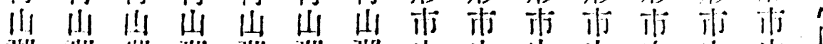

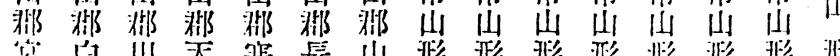

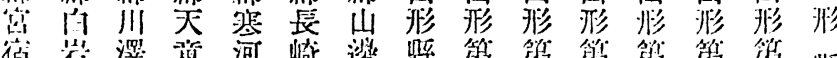

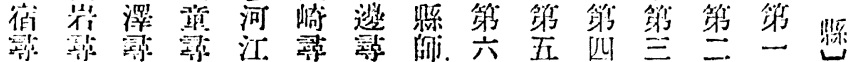

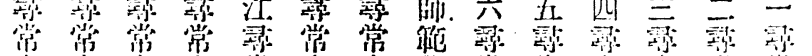

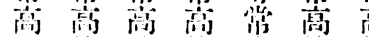

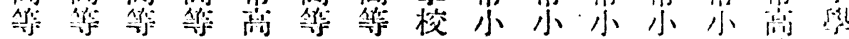

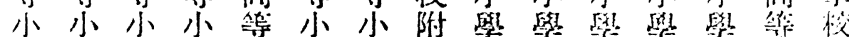

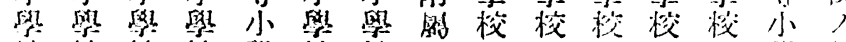

校 校 校 校 的 校 校 校
小

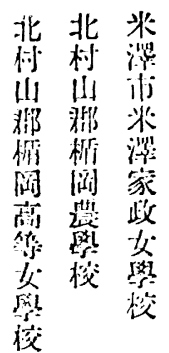

㽬

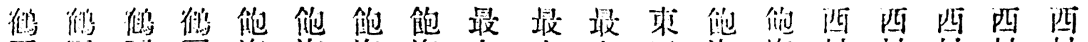

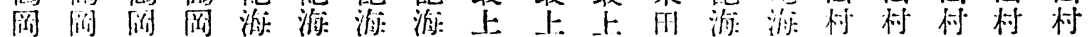

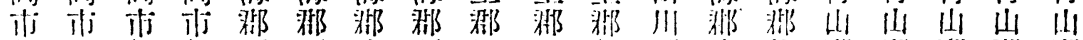

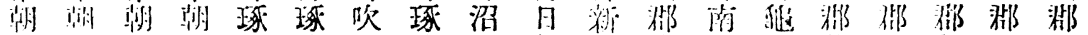

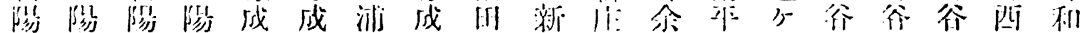

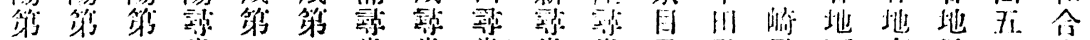

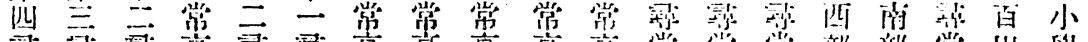

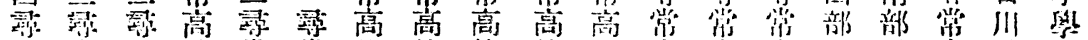

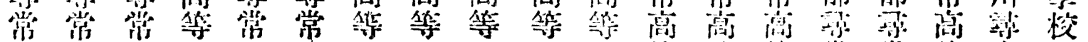

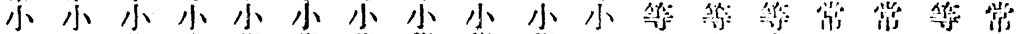

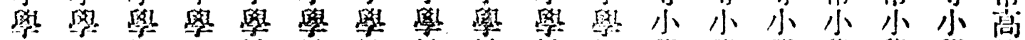

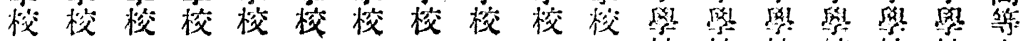

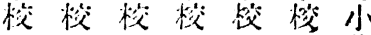

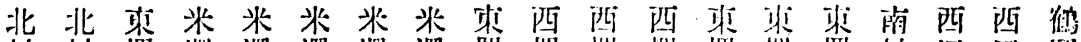

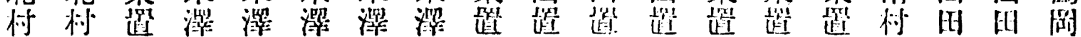

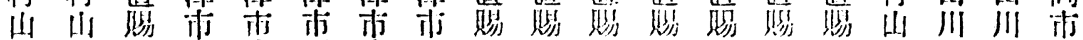

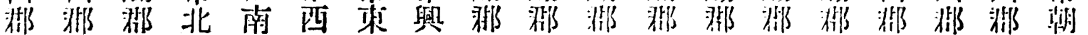

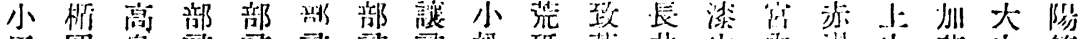

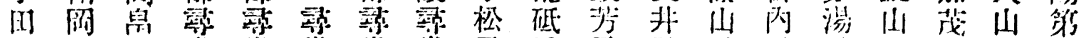

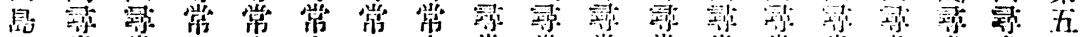

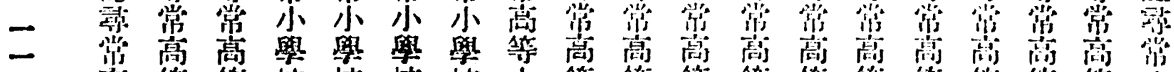

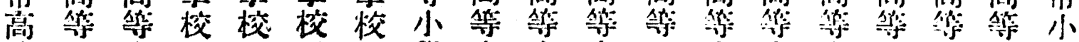

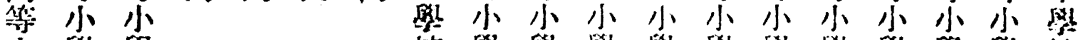

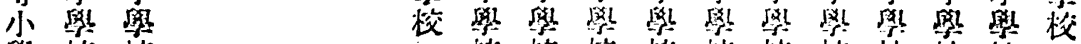

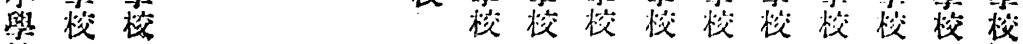




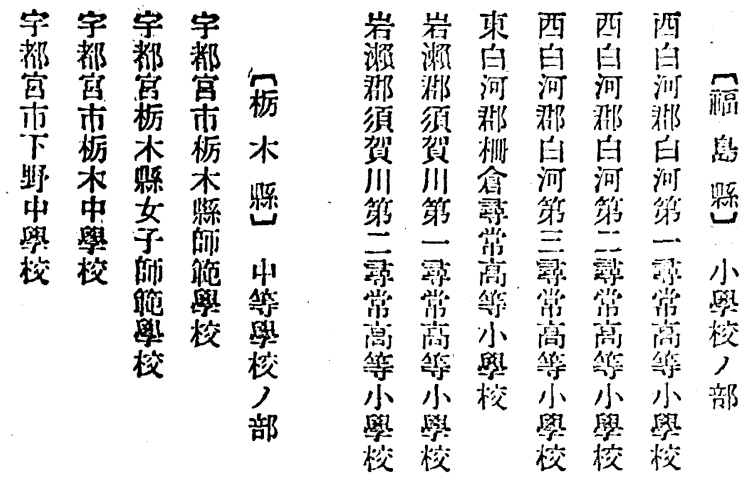

來北北北背

山 II II III III

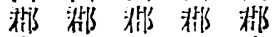

高增览大

籍潵 根花石

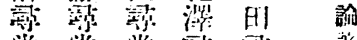

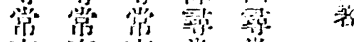

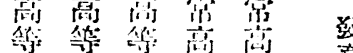

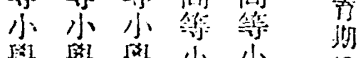

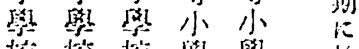

校校校罗鼠於

校

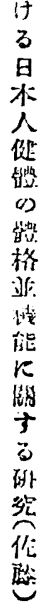

臨下古上安安安安宇宇综字

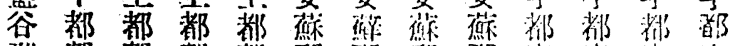

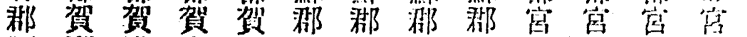

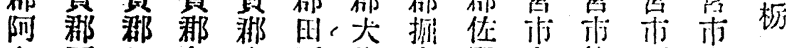

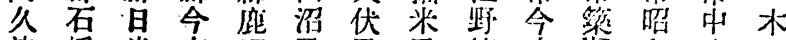

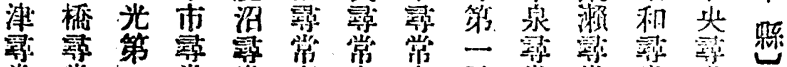

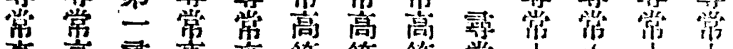

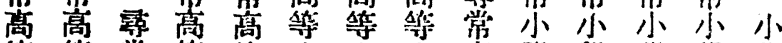

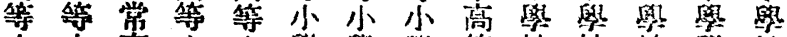

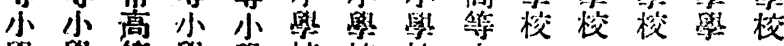

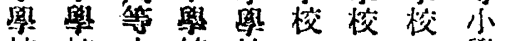

校 校 小校 校

學

學

部
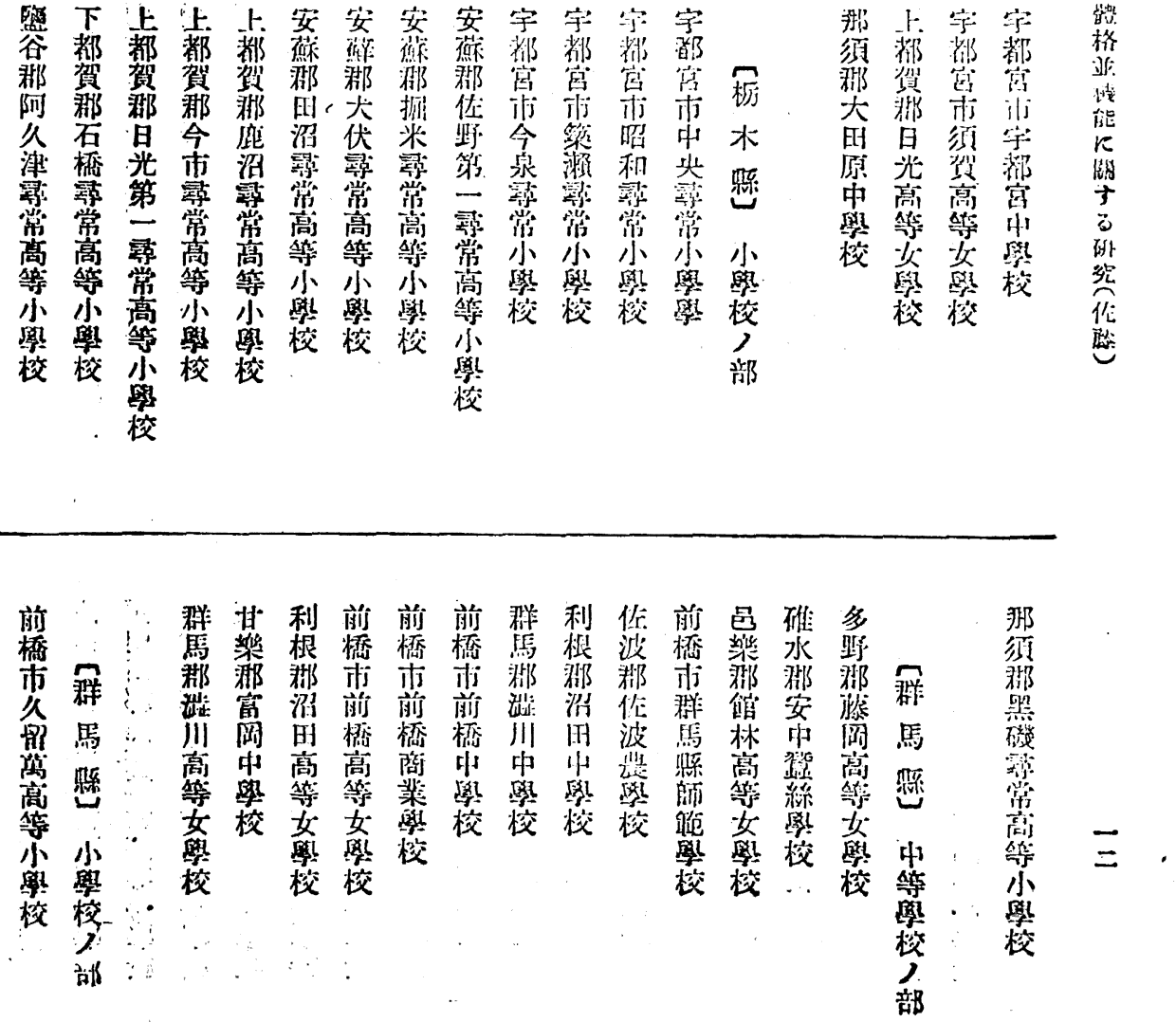


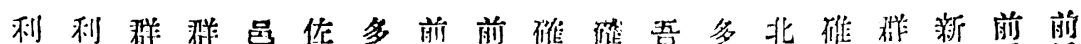

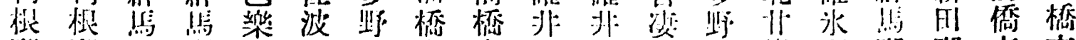

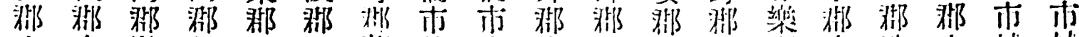

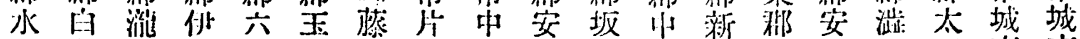

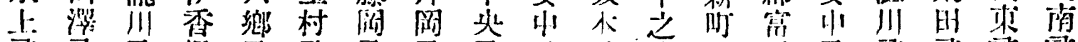

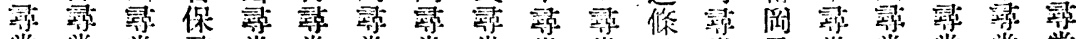

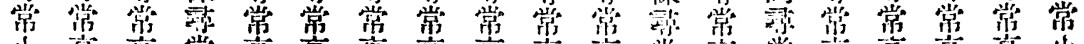

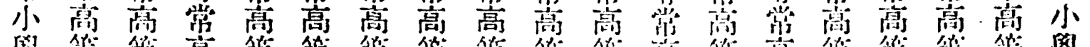

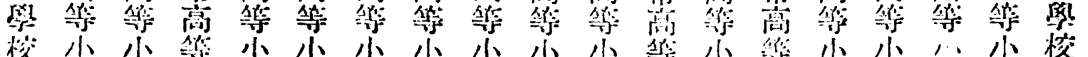

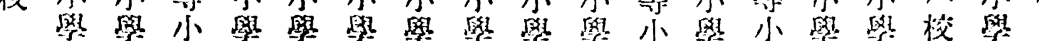

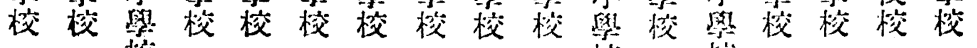

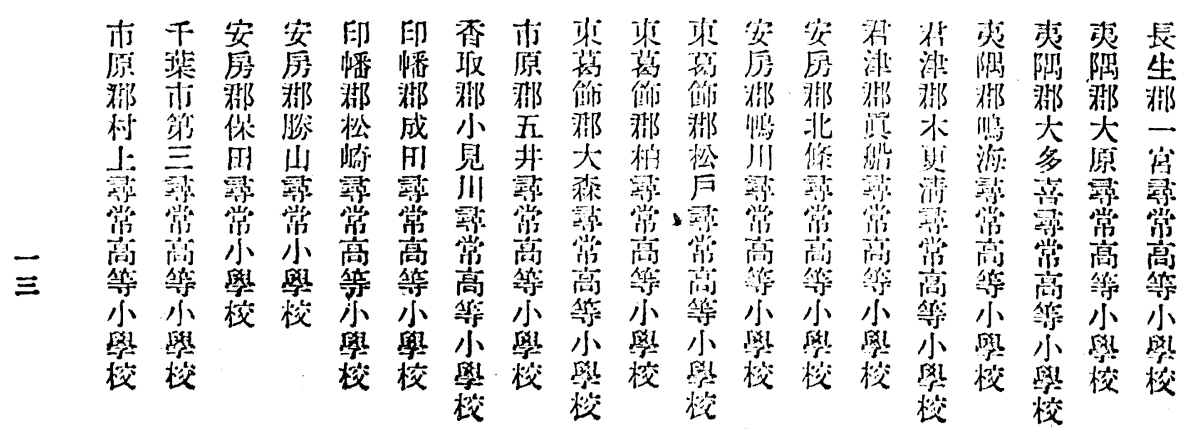


北北川

足足品方

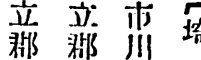

北比兒北北大大北比川北

藏海白王

符 谷靃惩

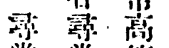

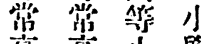

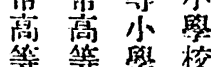

小尔校

残

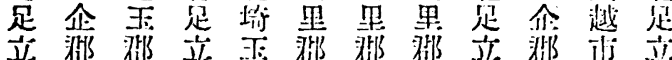

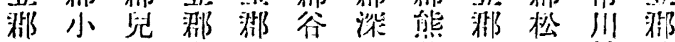

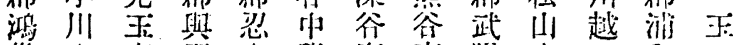

校 校

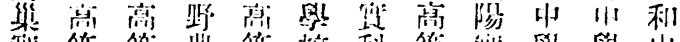

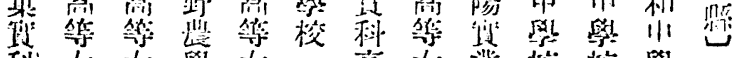

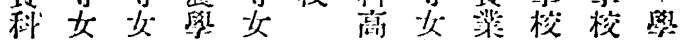

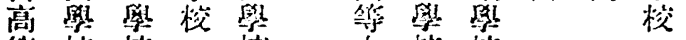

校校

女

女模校

校

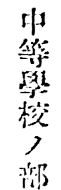

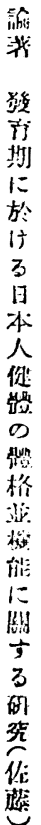

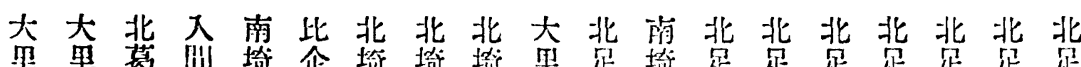

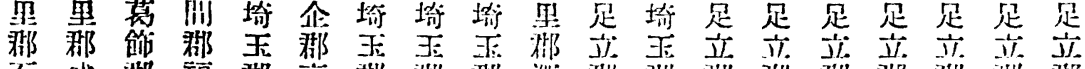

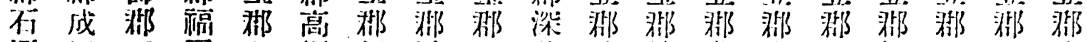

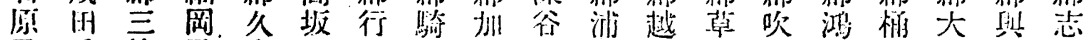

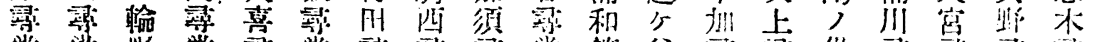

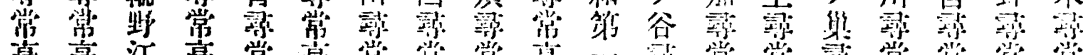

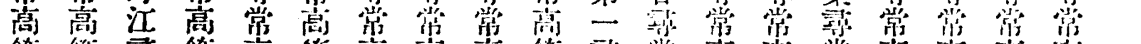

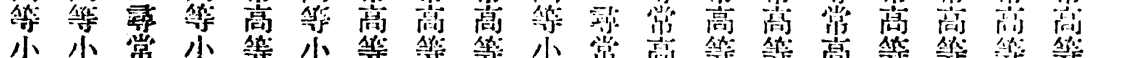

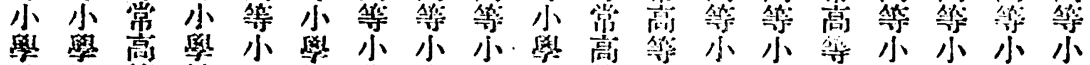

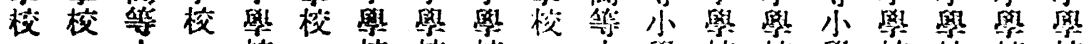
小校校校校少校校嶨校校校校

㬡

學 校校

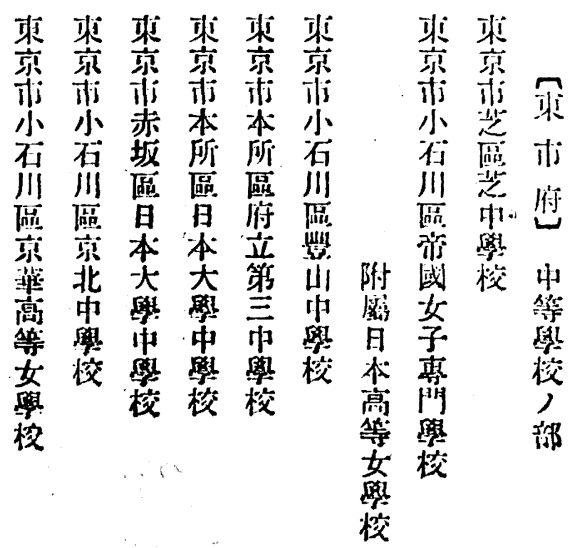

大 大 大 兒 兒大 大 大

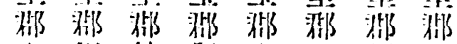

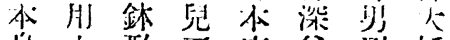

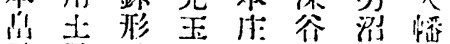

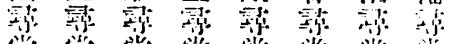

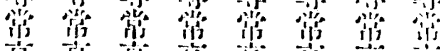

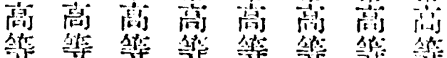

小小小小小小

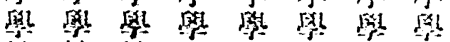

$\overrightarrow{\text { 四 }}$

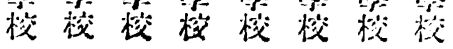




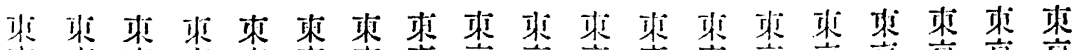

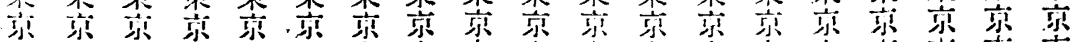

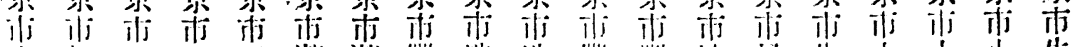

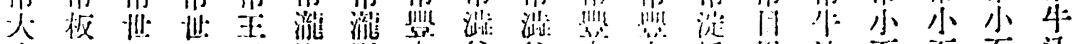

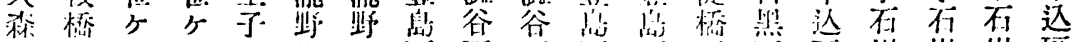

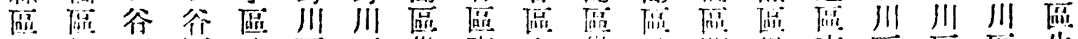

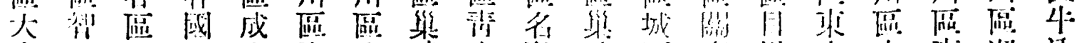

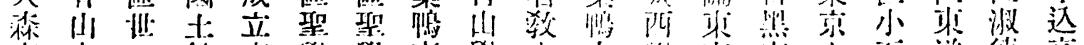

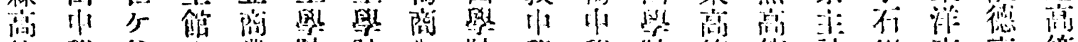

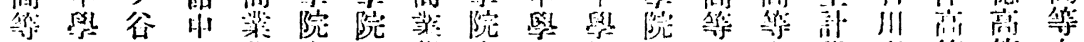

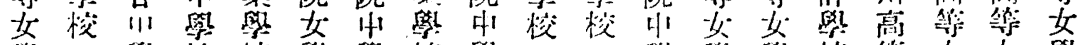

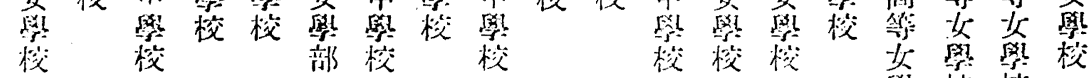

鼠校

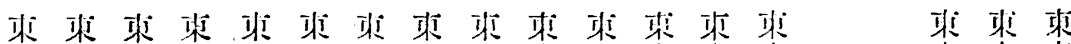

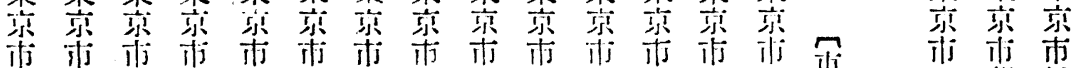

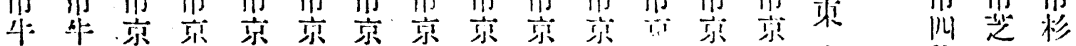

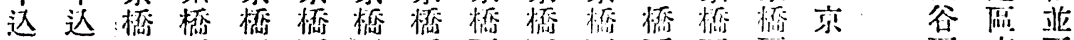

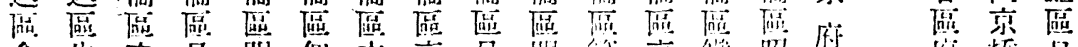

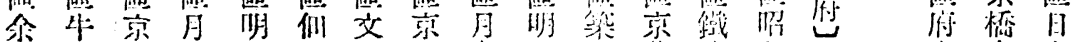

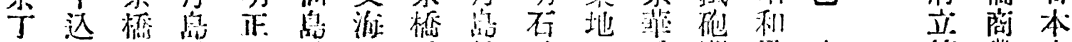

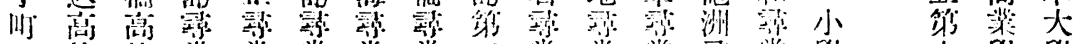

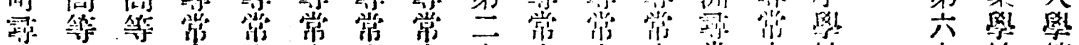

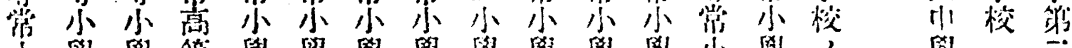

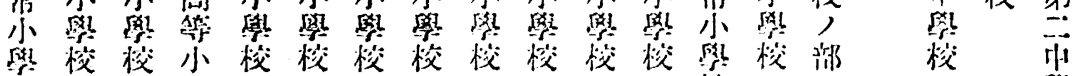

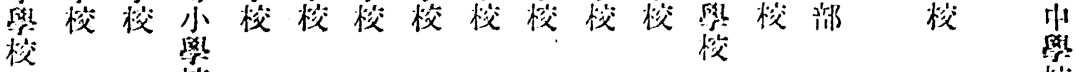

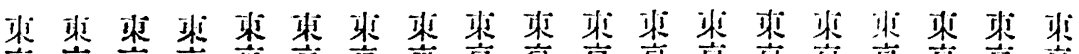

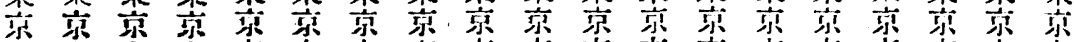

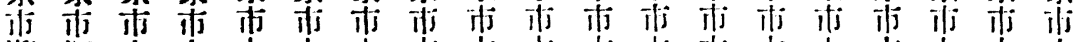

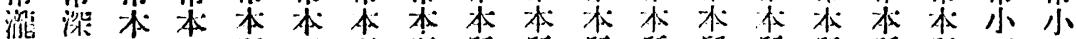

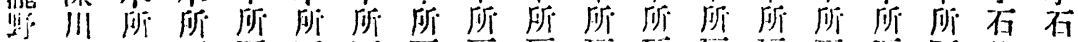

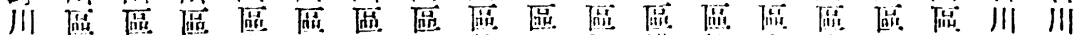

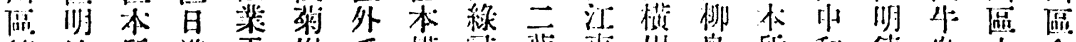

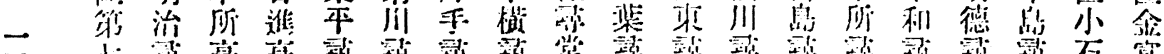

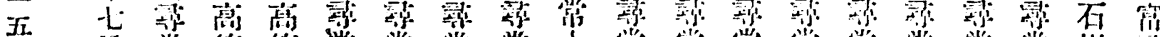

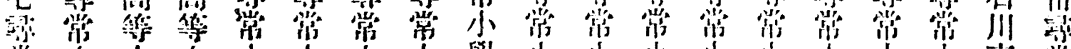

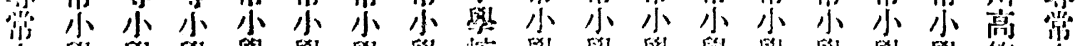

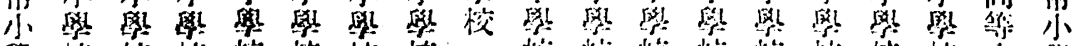

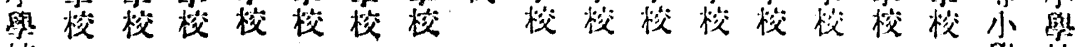
恔 


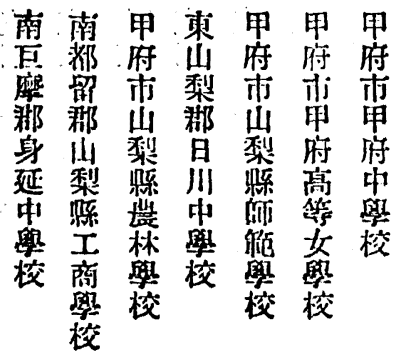

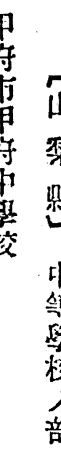

出

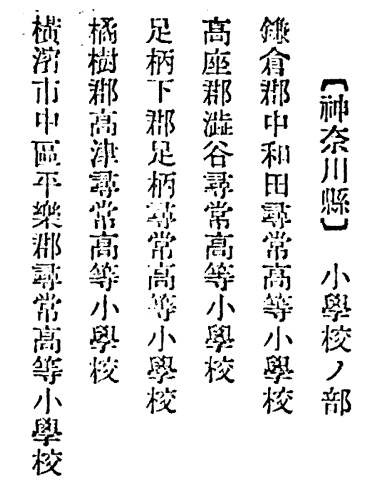

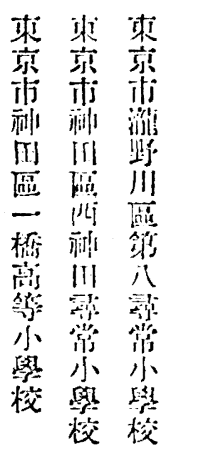

活

來東萠西西西北北北资资桨中中虫中

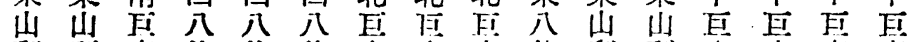

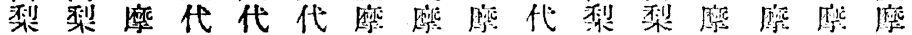

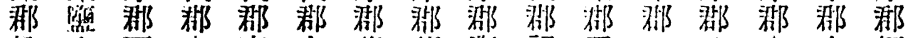

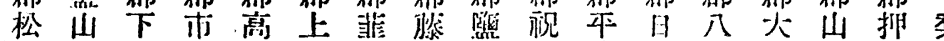

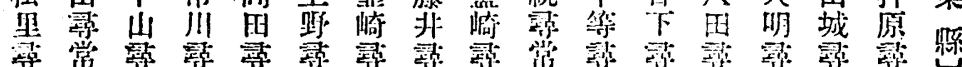

程 窟

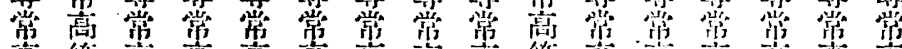

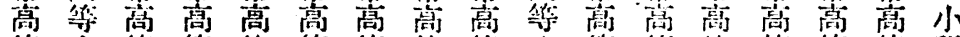

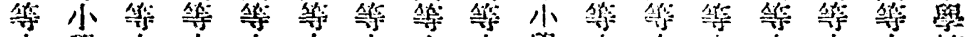

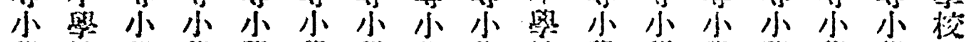

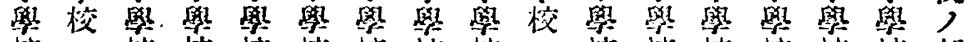

校校校校校校校校校 恔校 校 校校 部

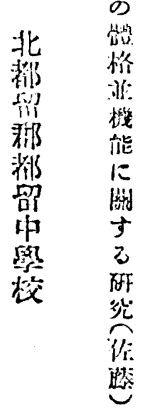

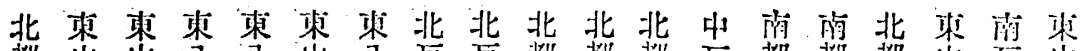

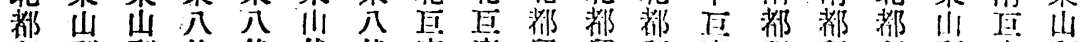

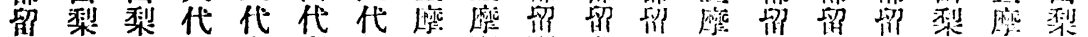

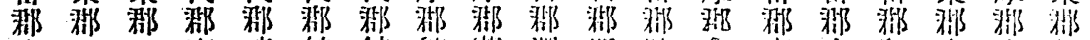

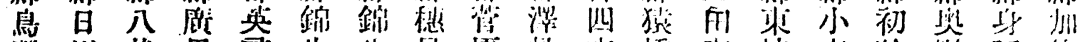

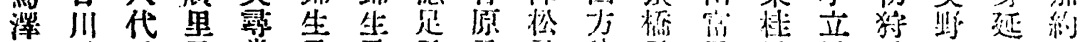

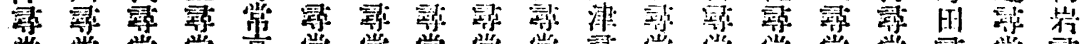

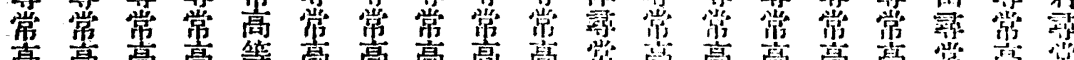

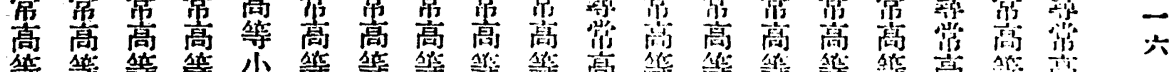

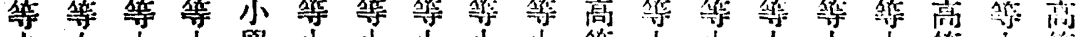

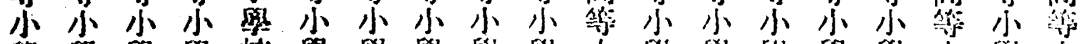

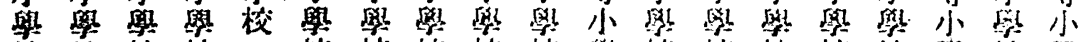

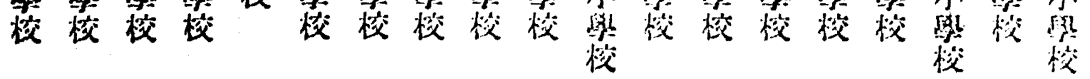



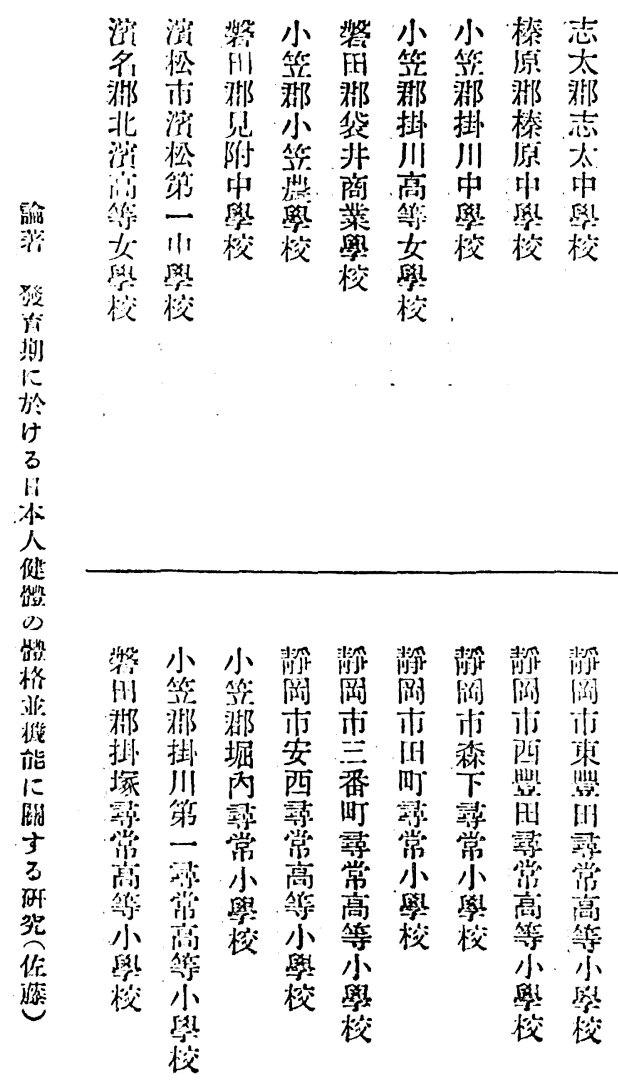

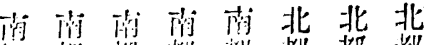

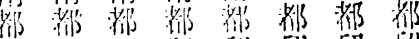
增留留監留留留

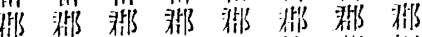

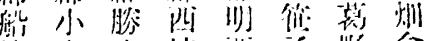

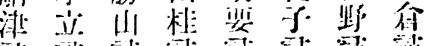

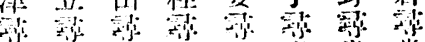

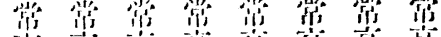

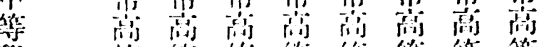
學维等 模 小小小小小少小

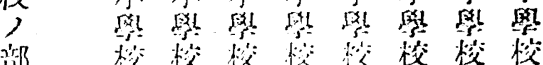

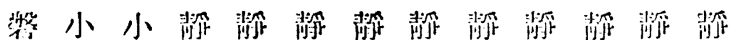

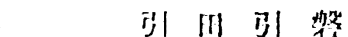

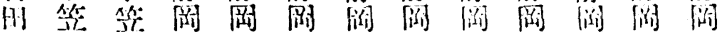
作师俈

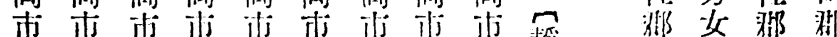

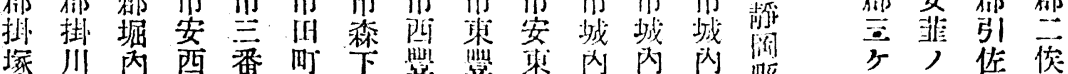

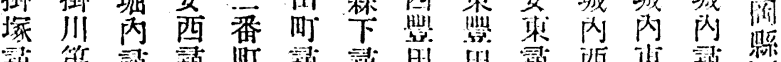

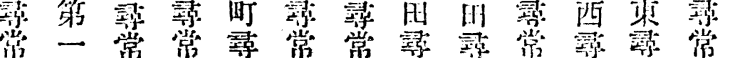

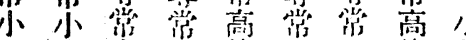

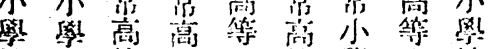
校 校等 等小等 學 小校

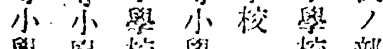

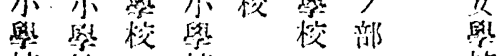
目山㢮管

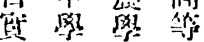
暞校 校 㰌 校 然

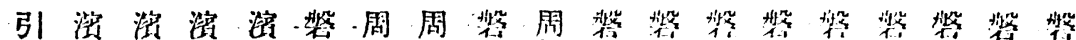

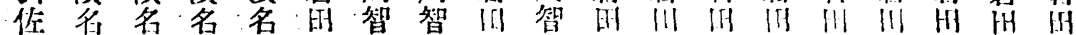

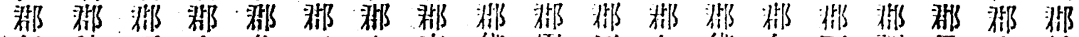

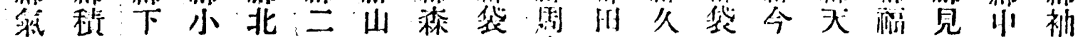

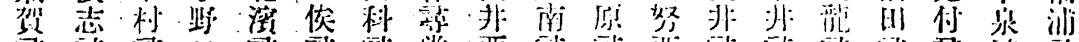

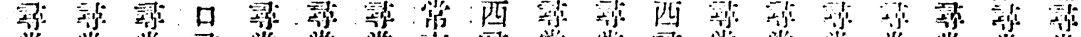

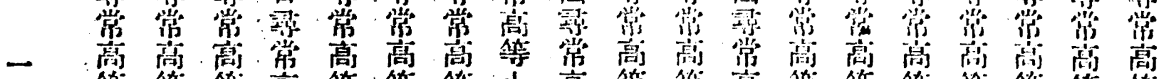

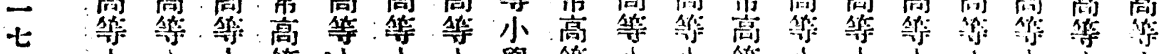
小小:小等少小少學小小等小小小小 小

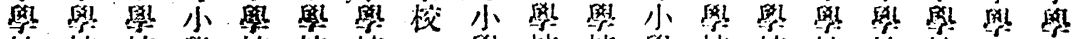

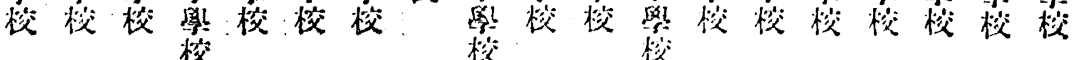




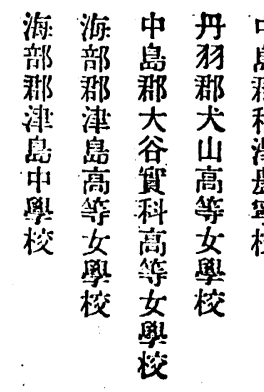

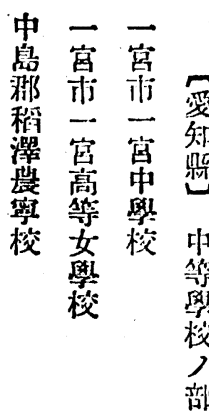

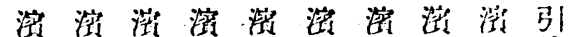

名名名名名名名界多住

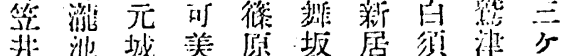

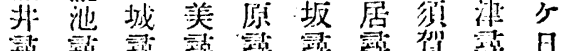

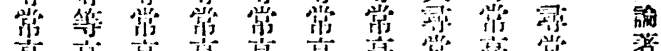

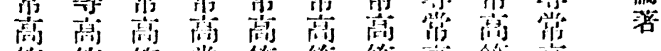

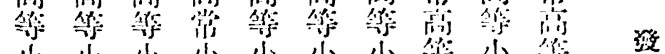

小小小小小小小篎小很留

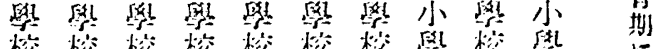

模模

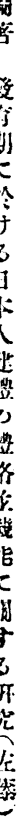

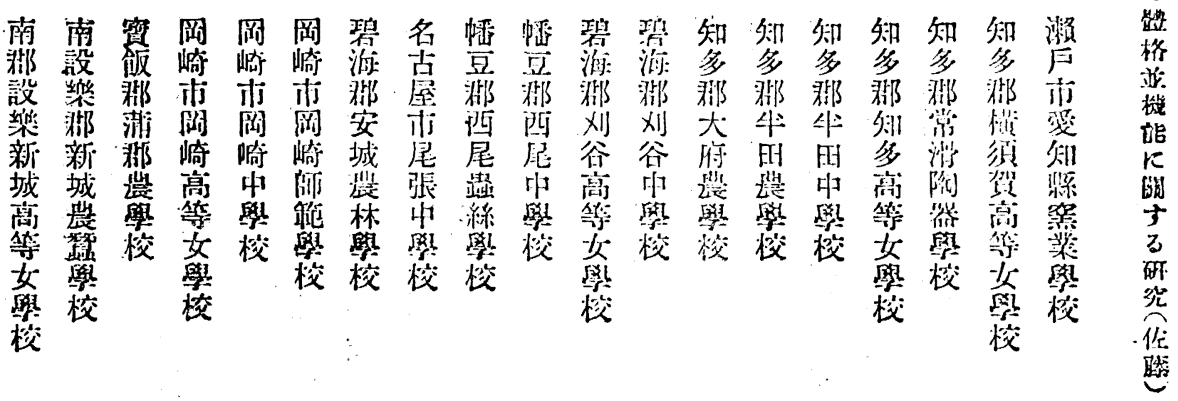

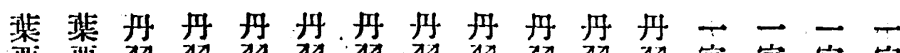

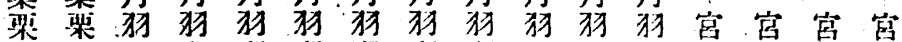

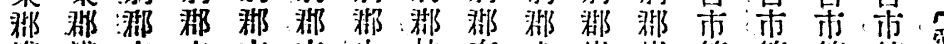

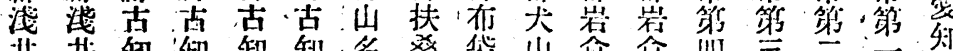

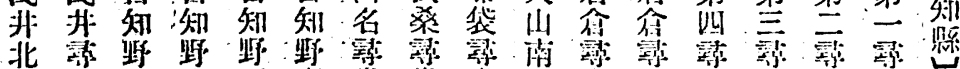

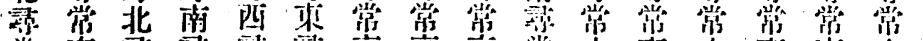

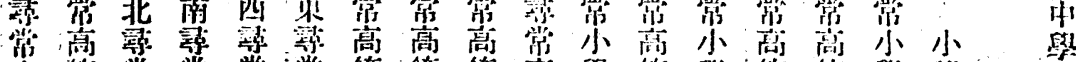

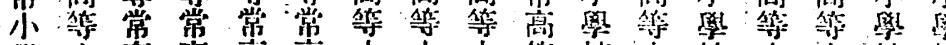

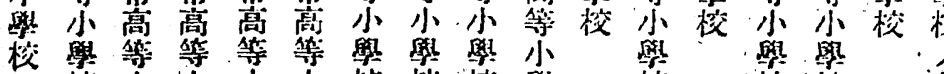
校 小少小校校校學

嶨 照

校榙部

校校校校 


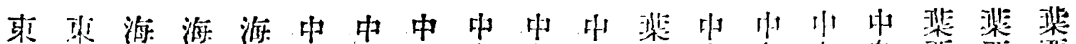

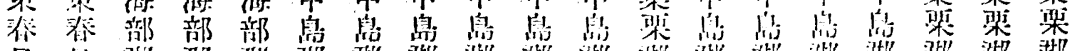

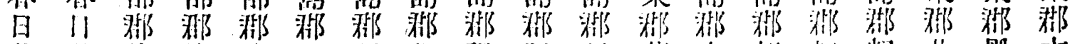

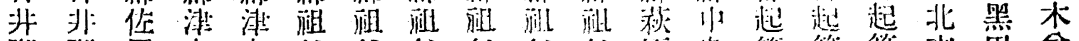

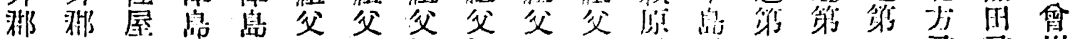

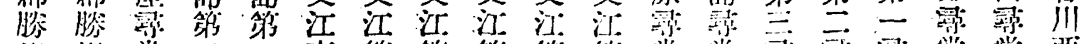

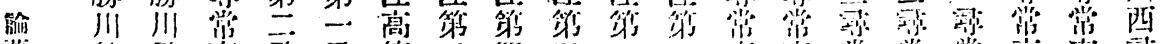

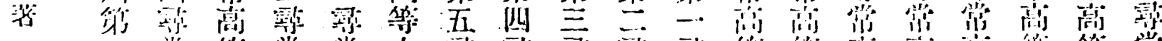

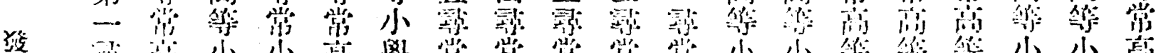

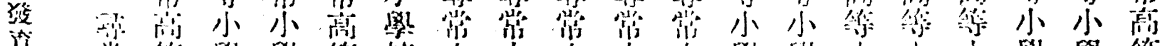

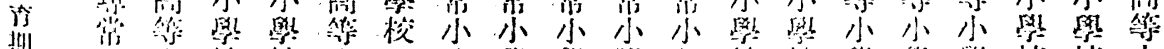

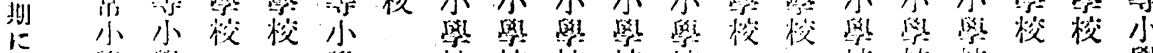

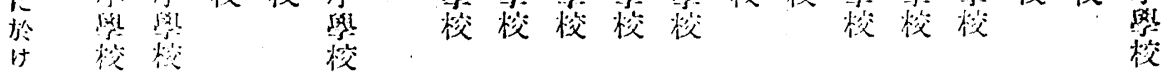

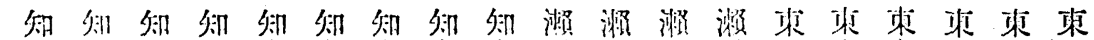

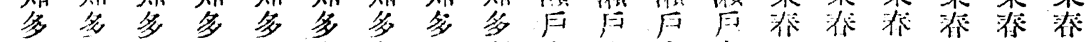

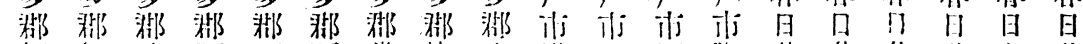

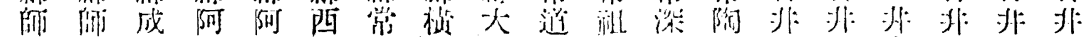

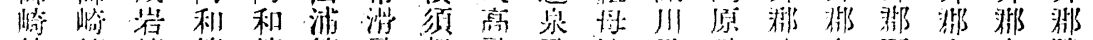

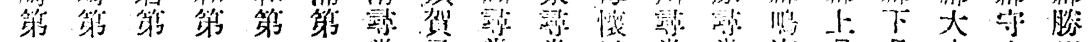

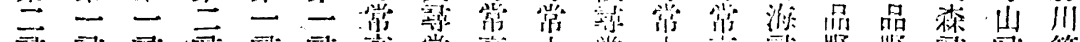

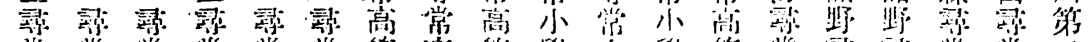

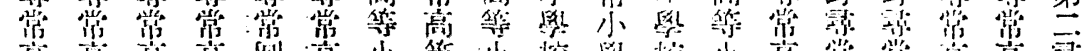

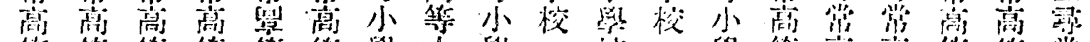

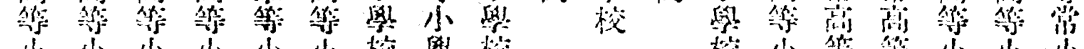

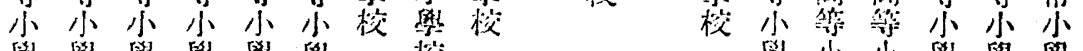

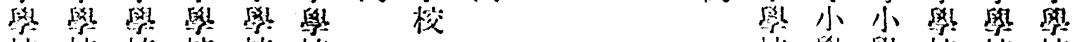

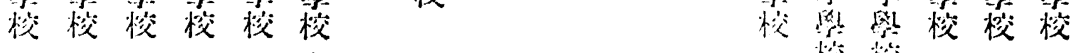
校 耀

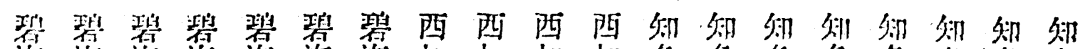

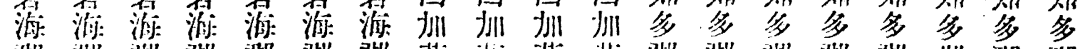

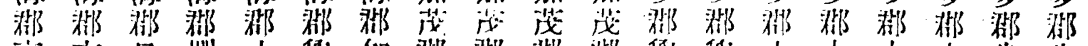

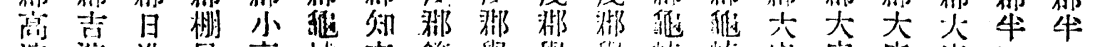

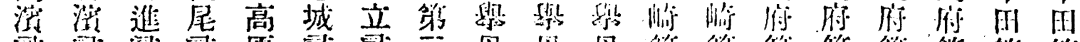

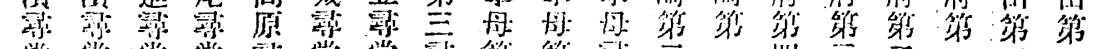

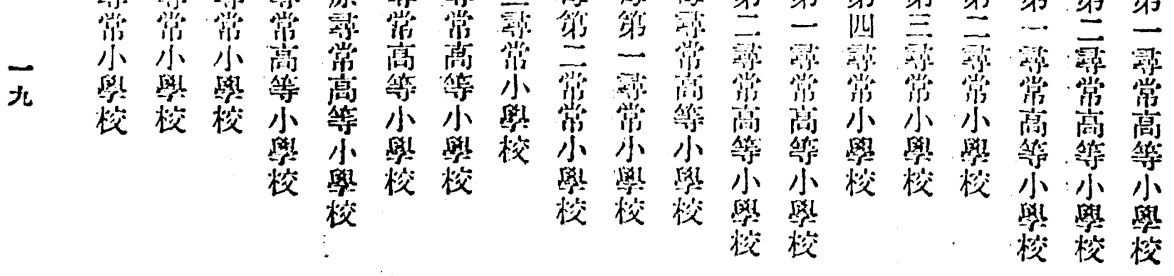




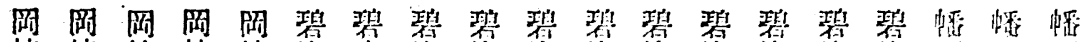

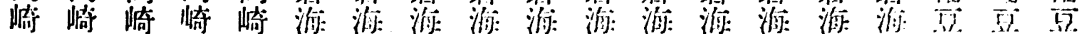

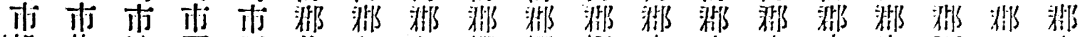

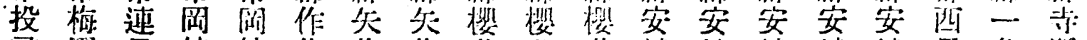

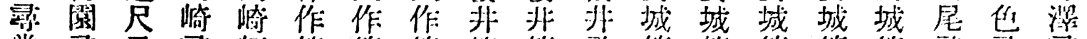

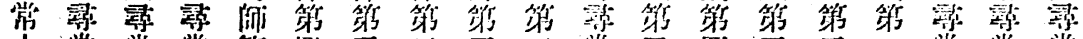

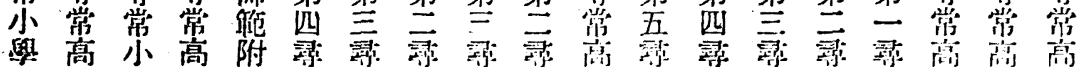

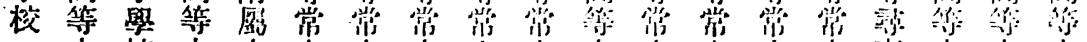
小校小小少小小小小少小绝

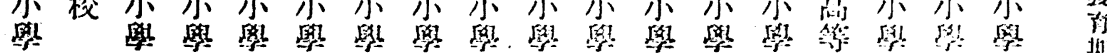

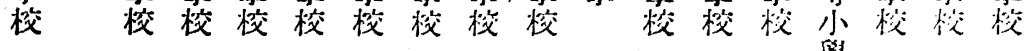

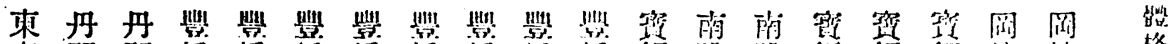

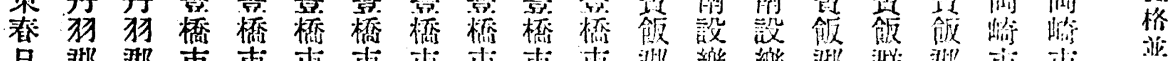

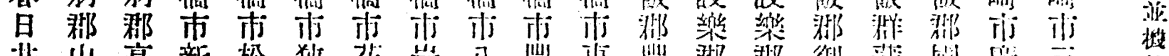

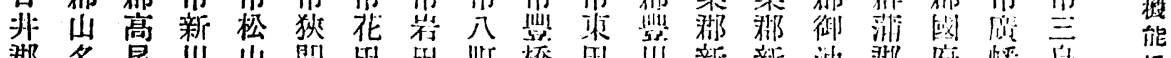

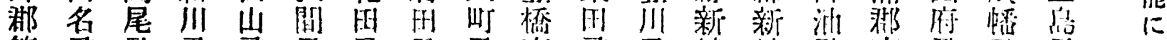

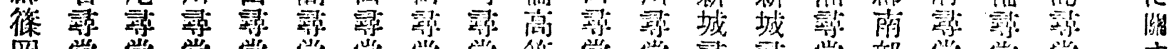

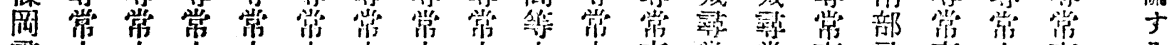

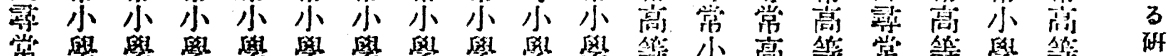

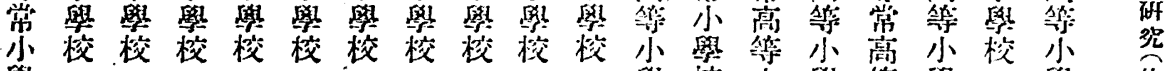

藇䍗

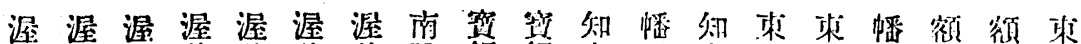

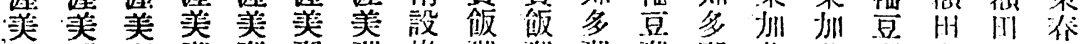

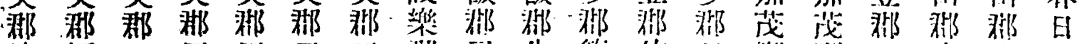

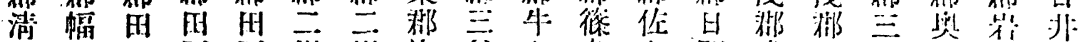

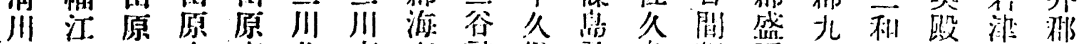

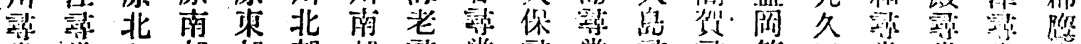

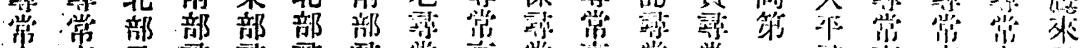

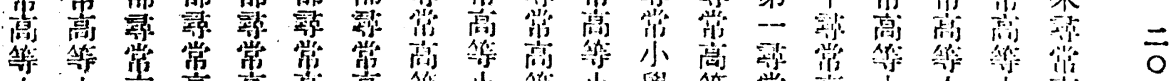

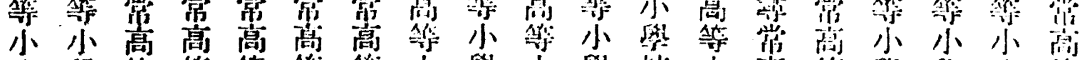

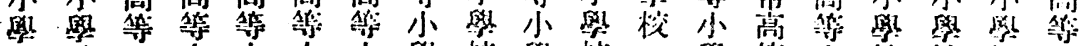

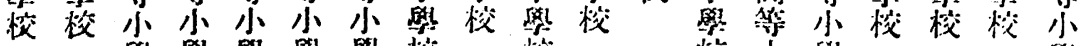

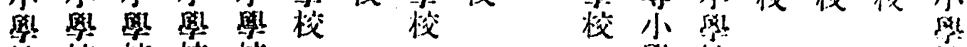
校校校校校校 


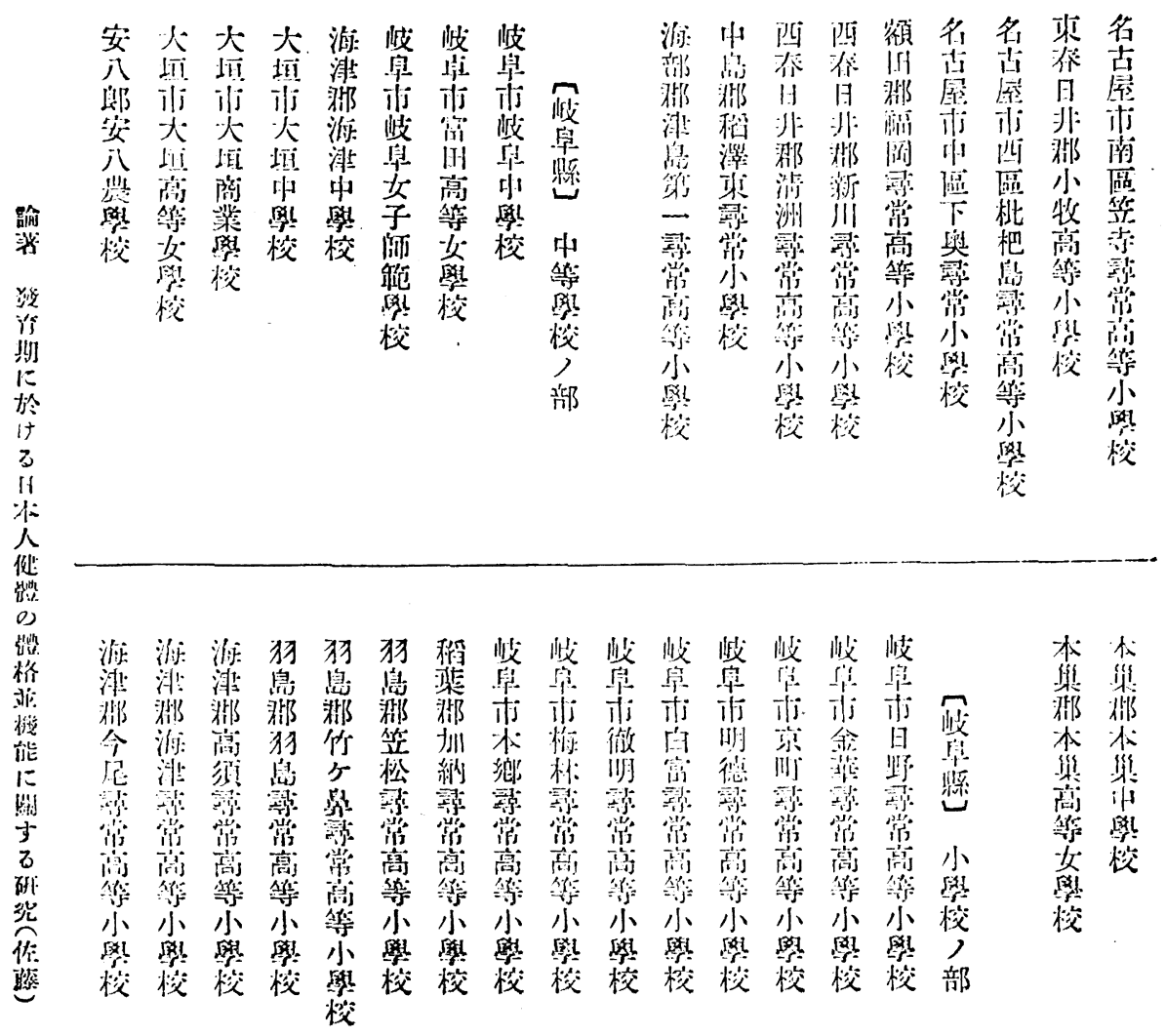

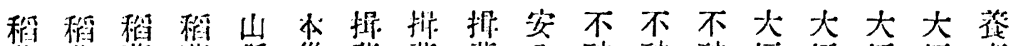

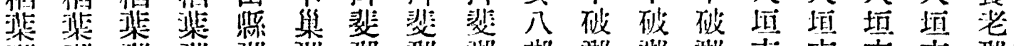

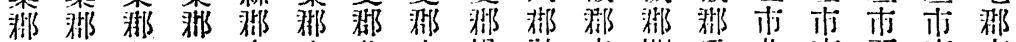

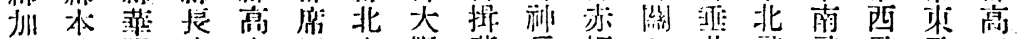

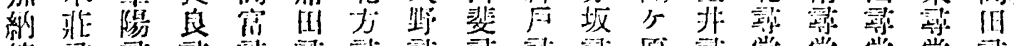

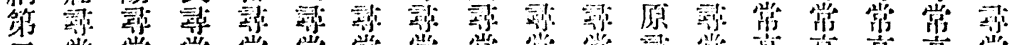

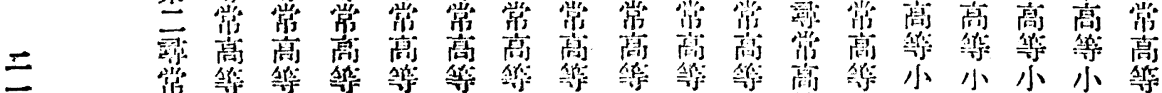

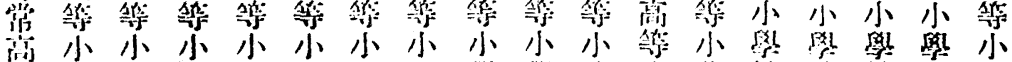

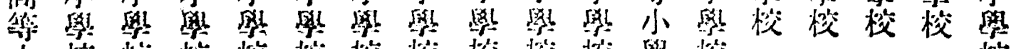

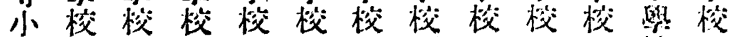
祭 校

䒝 


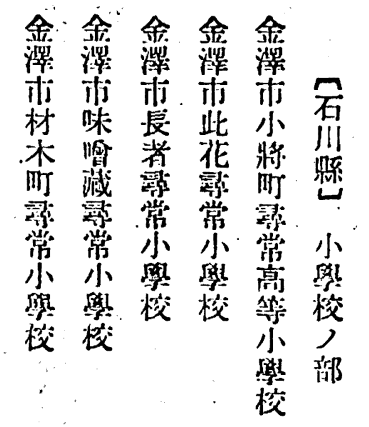

河䳸風珠石石金金金食食

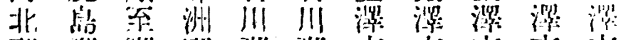

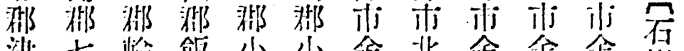

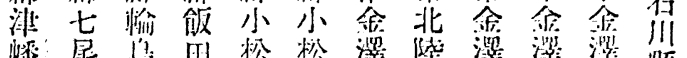

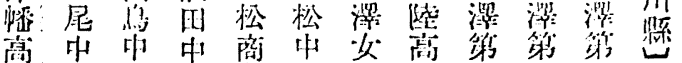

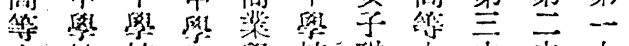

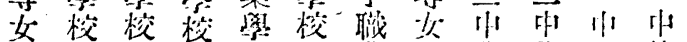

諭

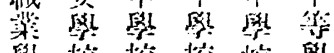

榙

毁校校 核 校

櫋

留

け

3

次

人

健

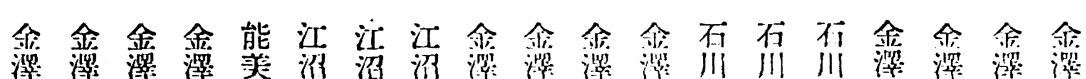

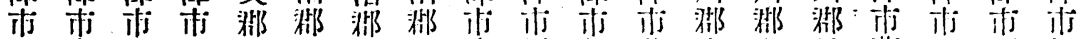

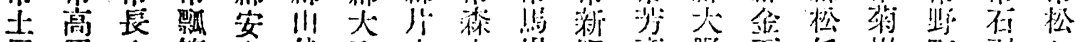

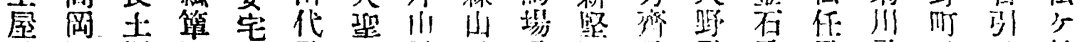

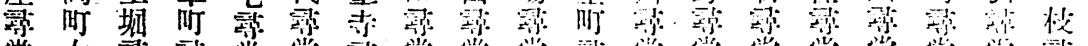

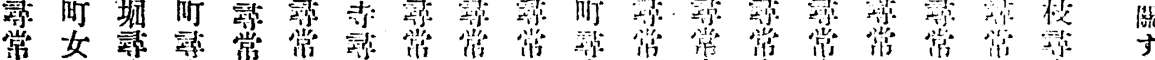

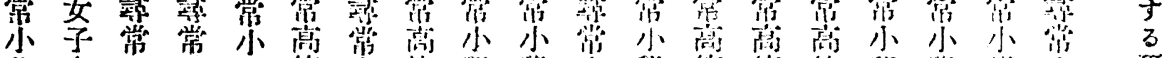

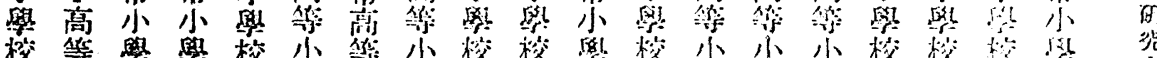

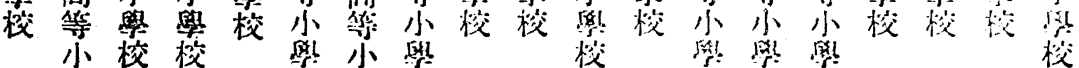
凩! 校 校學校 校 椟

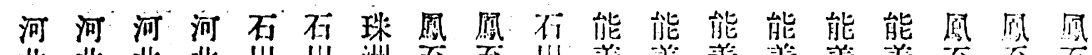

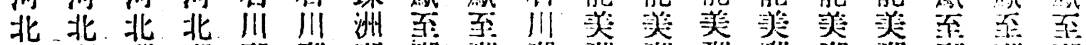

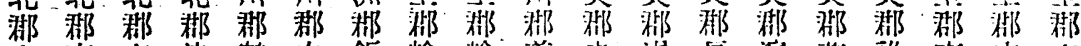

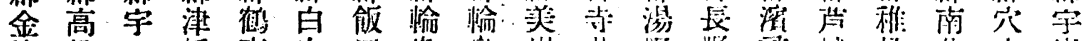

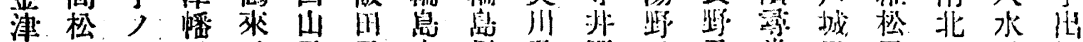

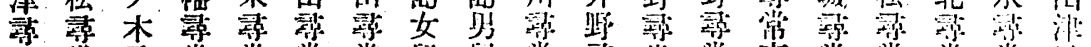

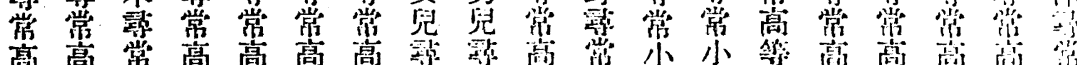

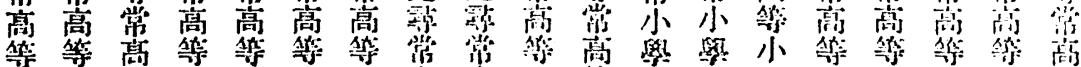

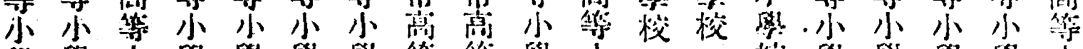

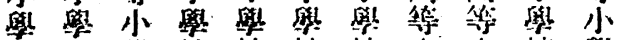

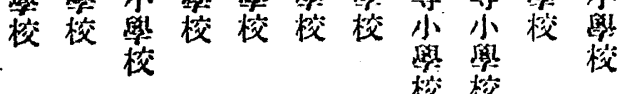

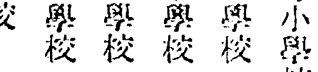



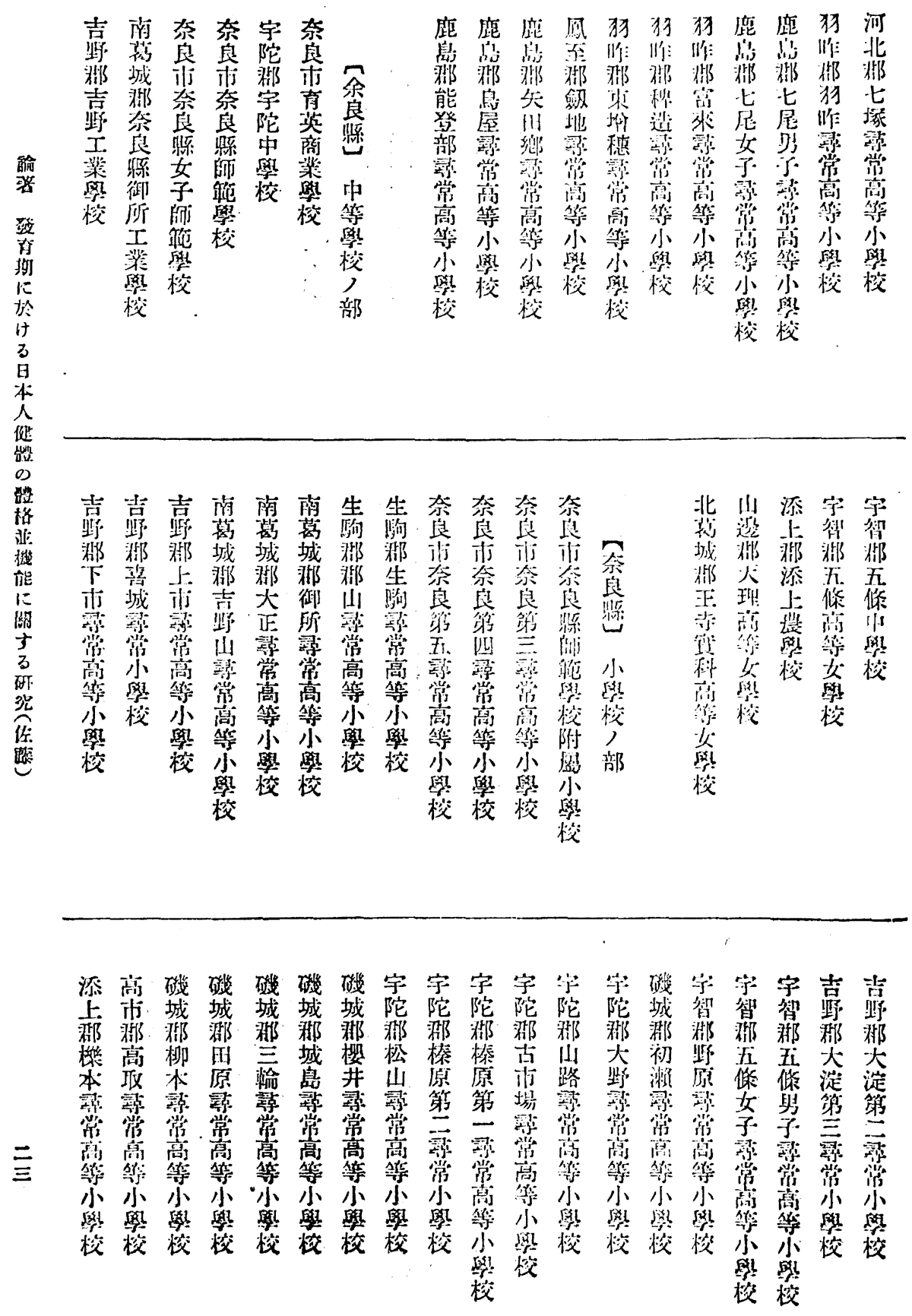


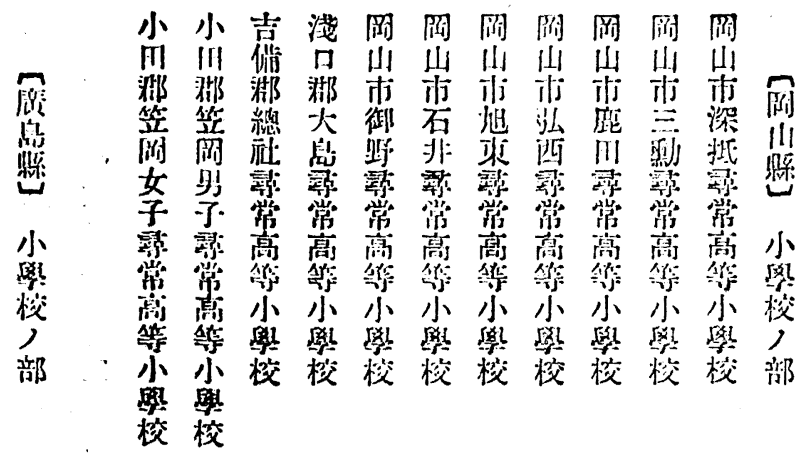

北北北 北

城城 城城

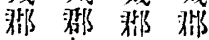

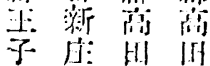

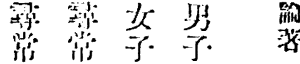

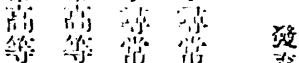

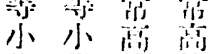

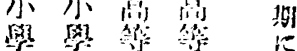

校校小小於

䑁 格

等

炎

健

政:

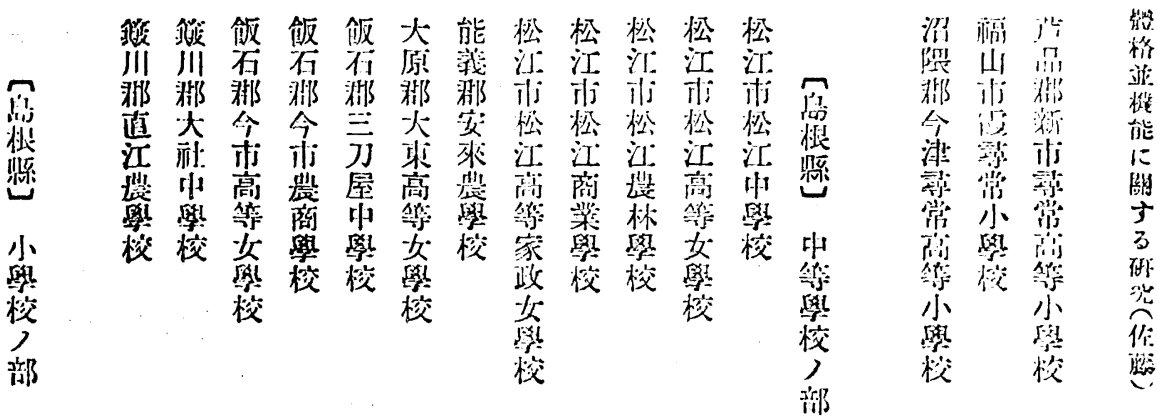

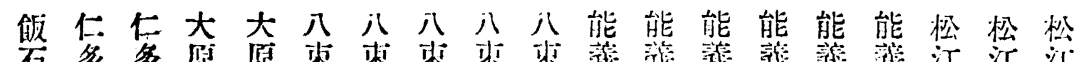

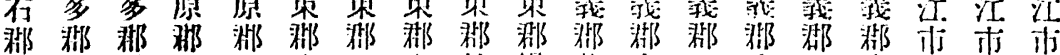

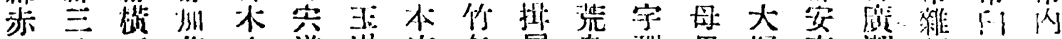

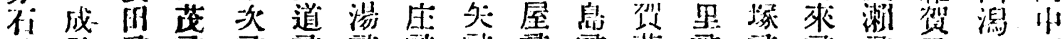

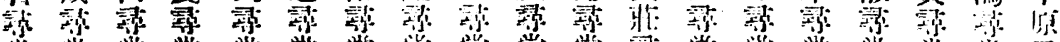

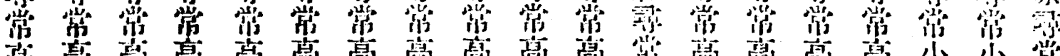

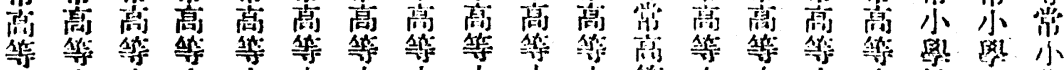

小小小小小小小小小小少小少小校苓影

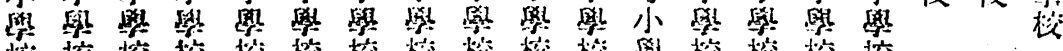

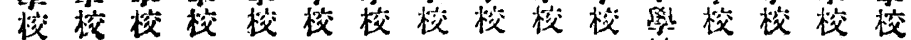



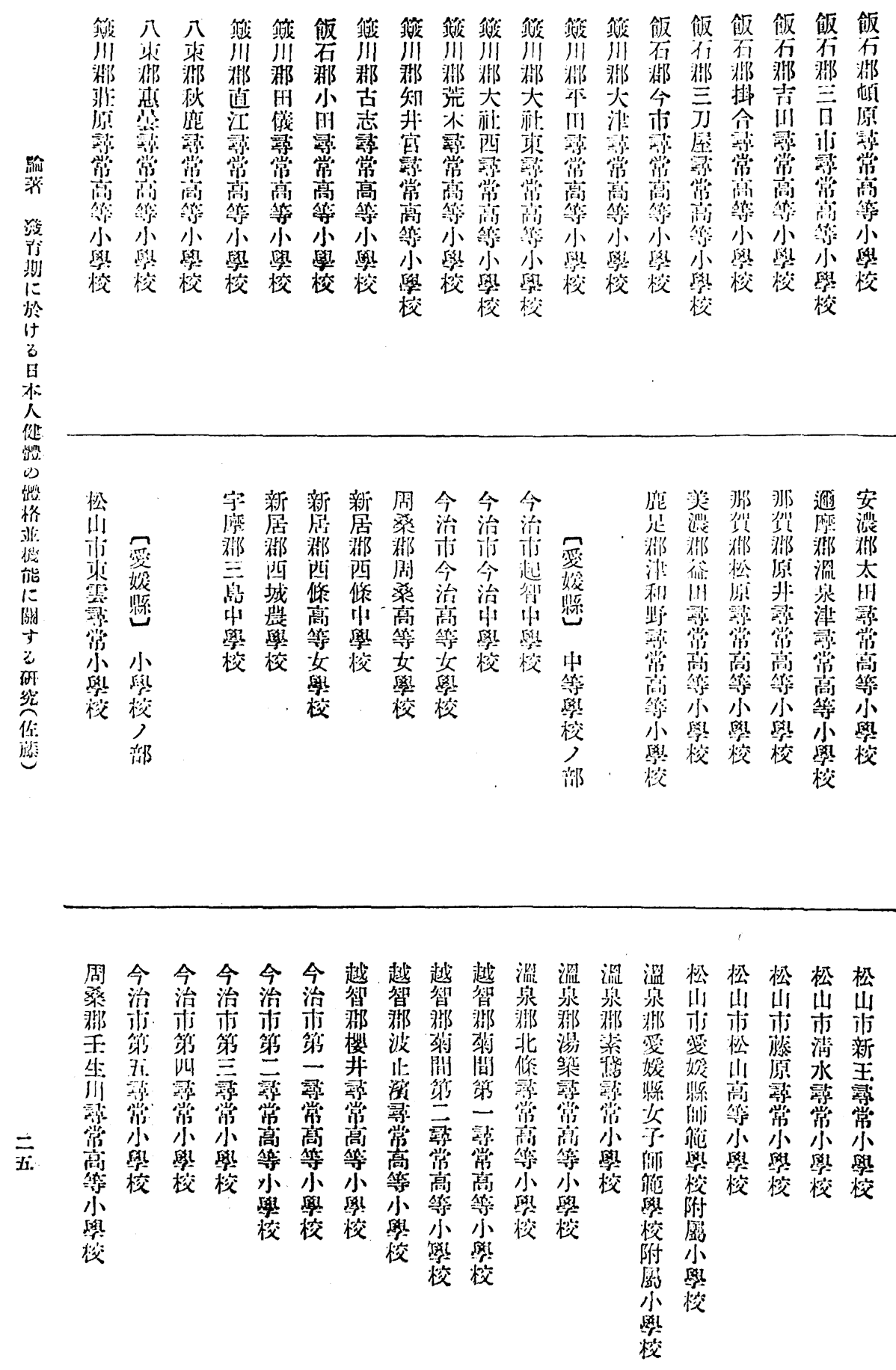
伊，伊伊：伊上字字字新新新新新周䉼新新网 1 月

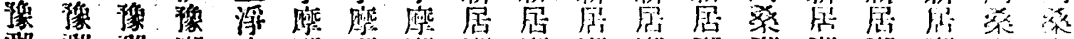

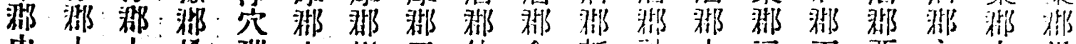

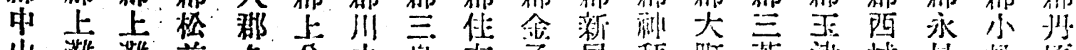

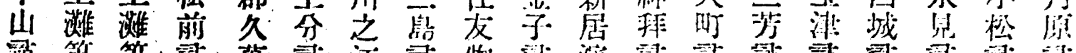

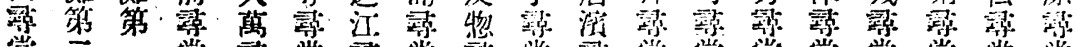

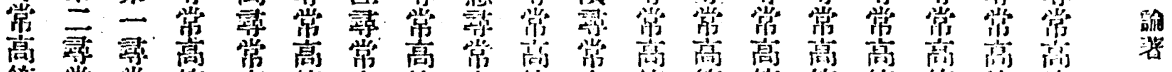

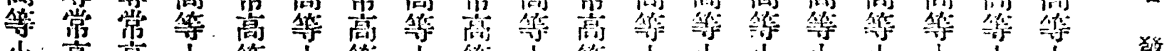

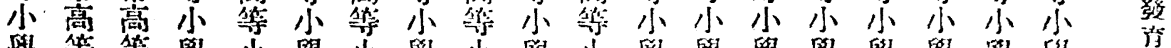

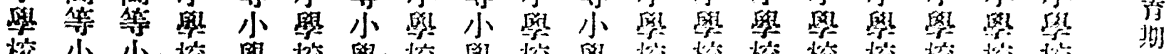

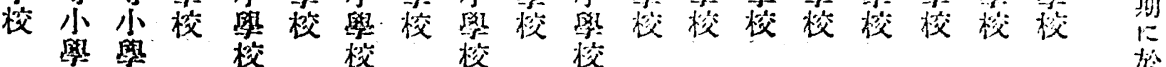

校 校

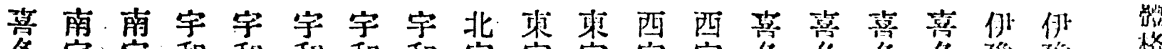

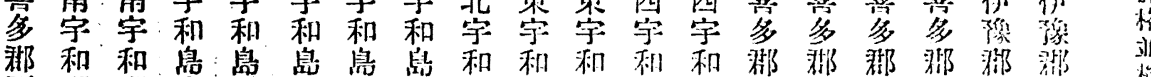

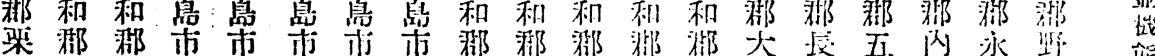

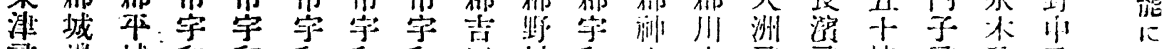

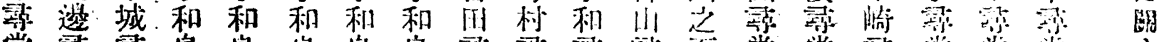

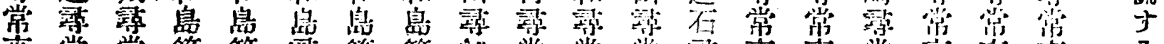

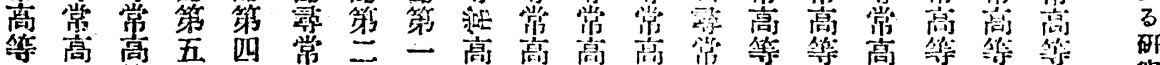

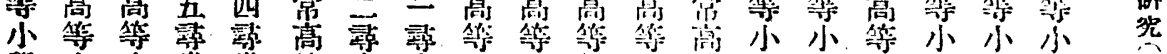

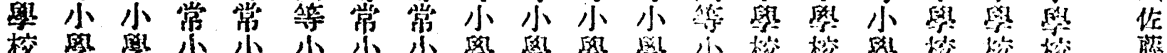

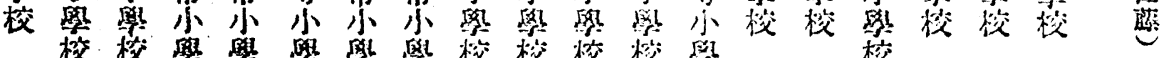

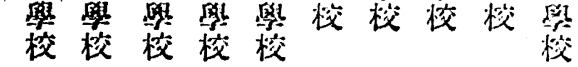

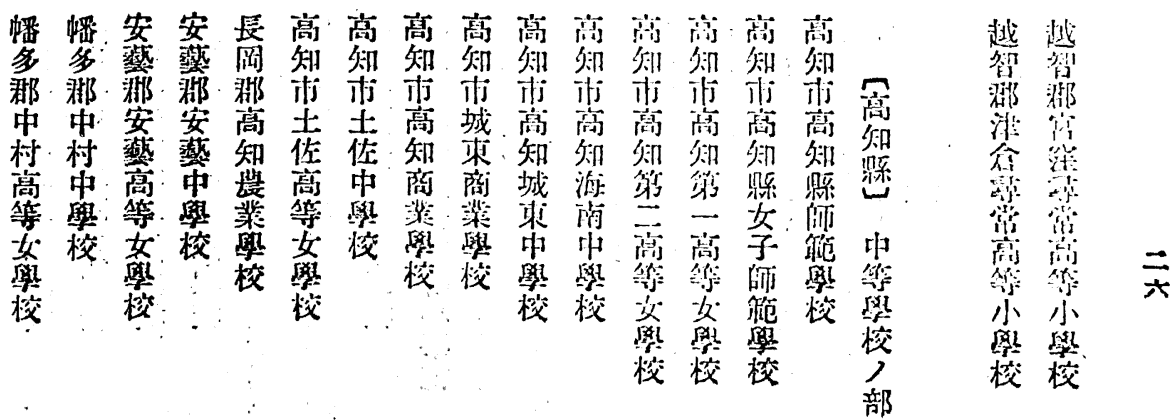




\section{VI觢 137}

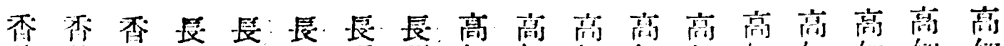

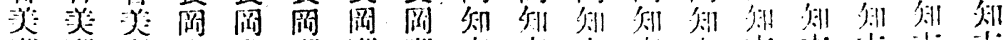

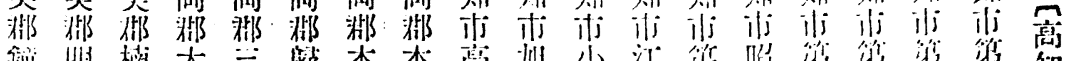

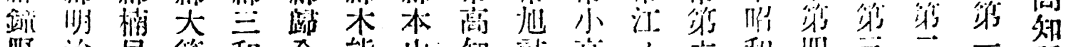

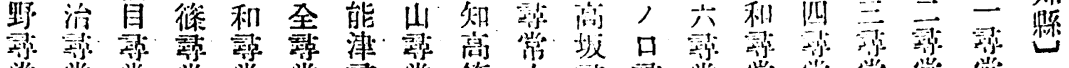

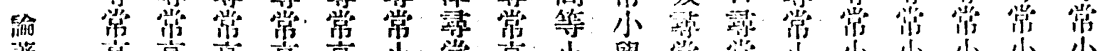

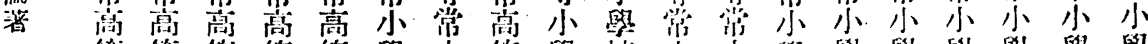

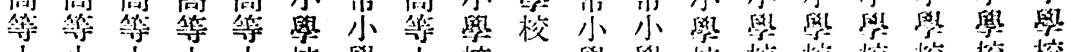

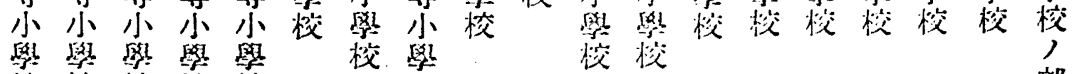

校校 校校校校

吾玨吾安安安奖安安香香香香香香香長長長

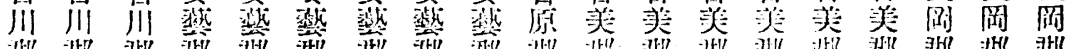

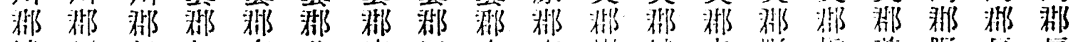

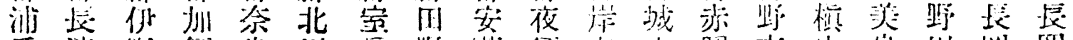

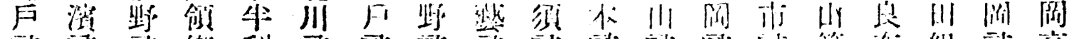

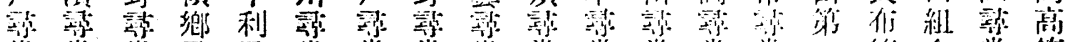

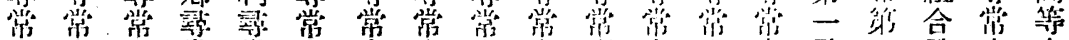

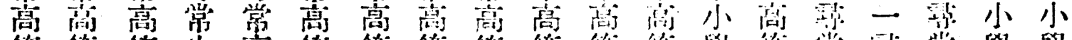

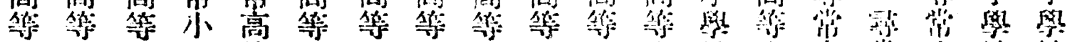

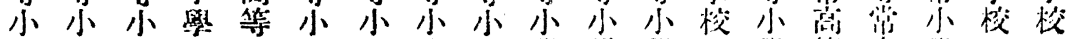

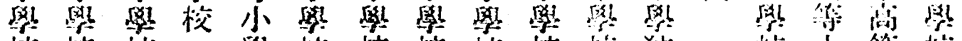

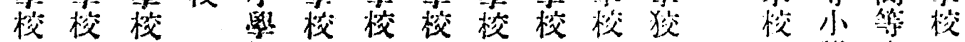
校

叟少

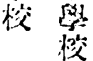

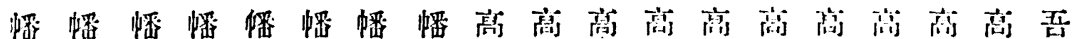
多多多多多多多多间此阔泪阔阔阔阔阔阔川

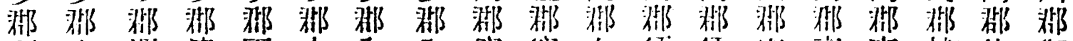

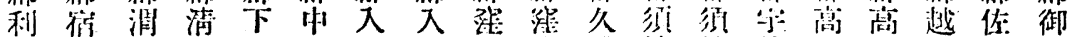

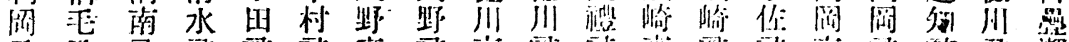

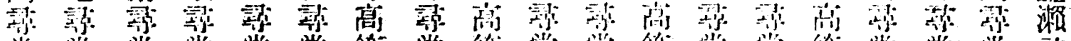

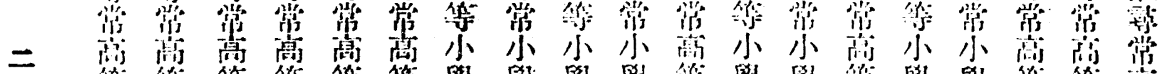

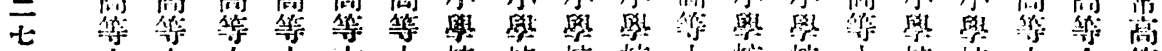

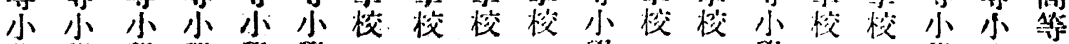

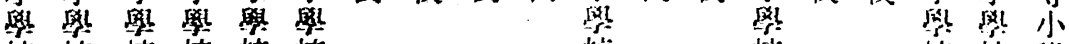
梭校校校校校校校模奴 


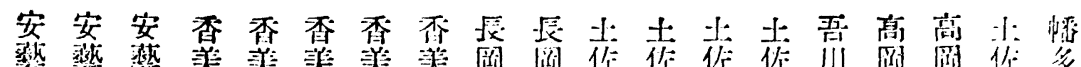

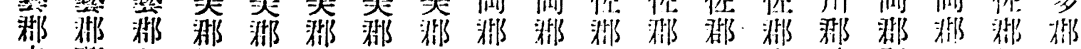

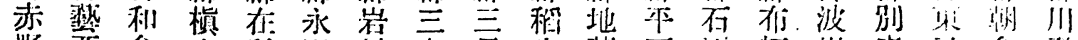

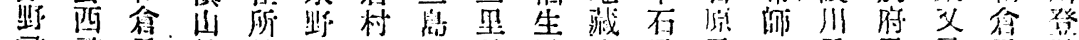

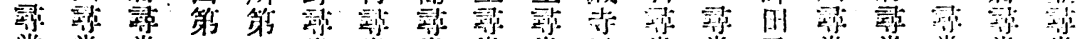

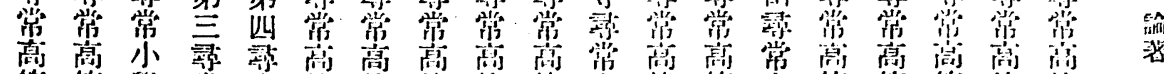

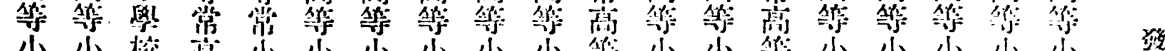

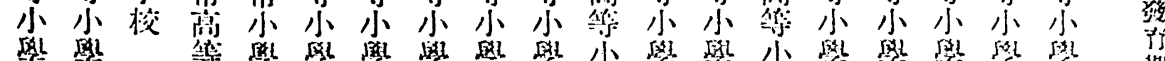

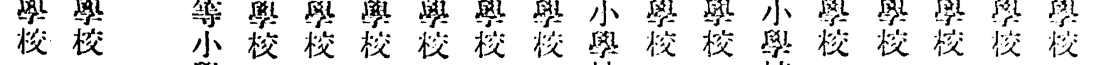
相

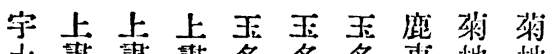

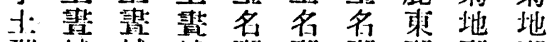

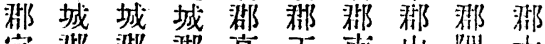

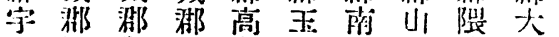

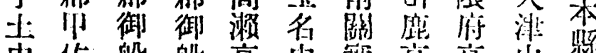

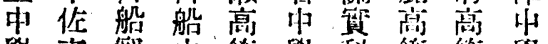

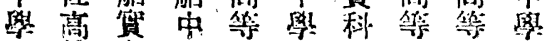

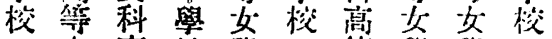

安高茭 奥

煘等 校

校

祭
等 嚳

學
部

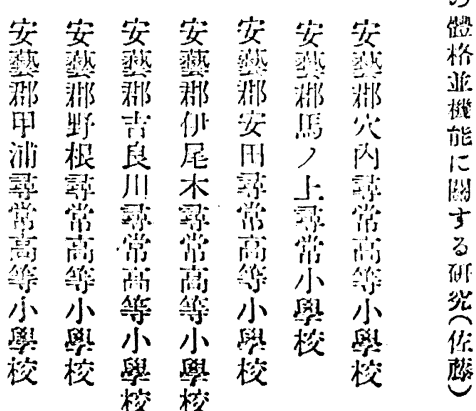

校 校

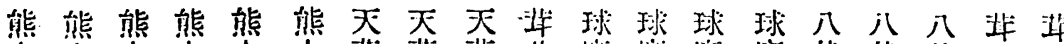

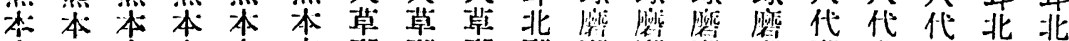

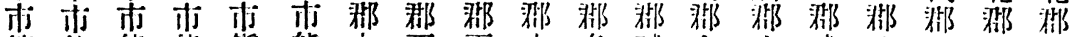

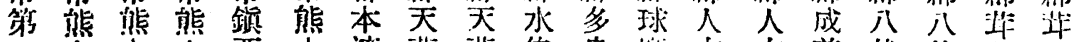

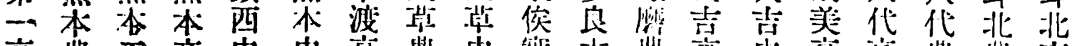

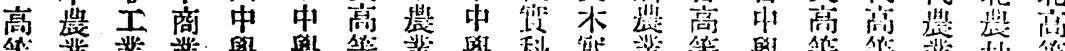

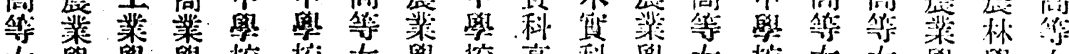

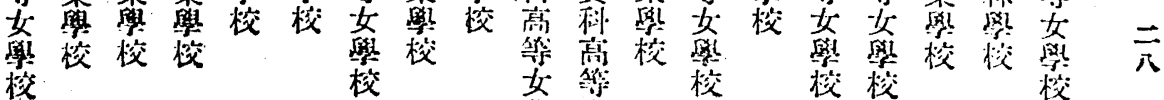
妙校校校

器学 
VI徍 199

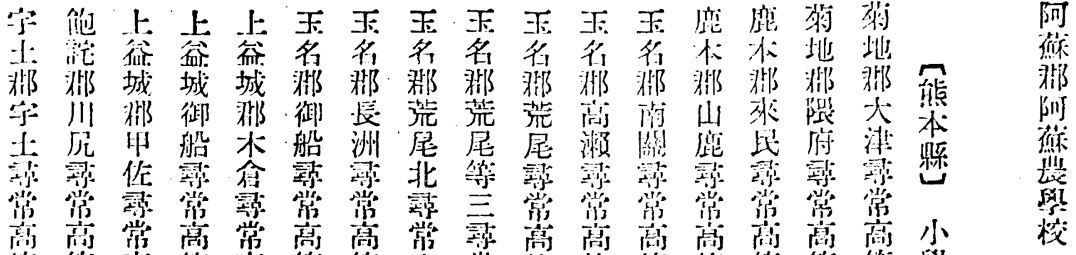

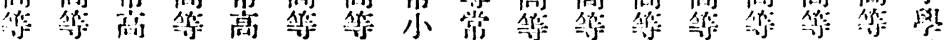

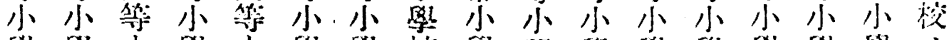

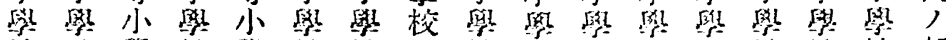

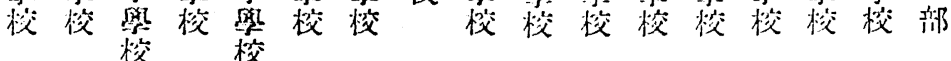

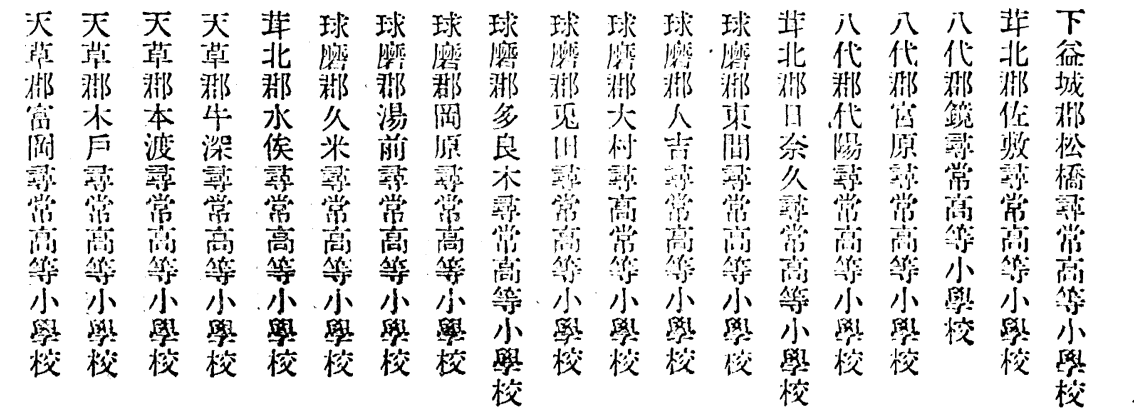

熊熊熊熊熊熊熊熊熊熊熊侦熊熊熊熊宇年 天

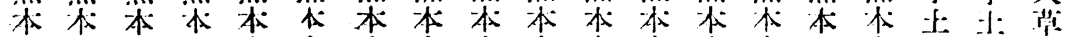

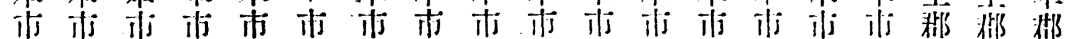

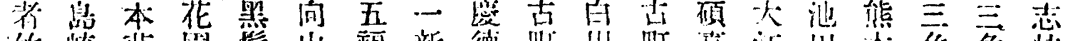

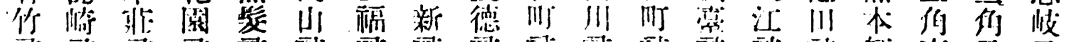

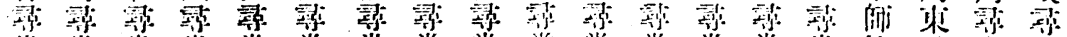

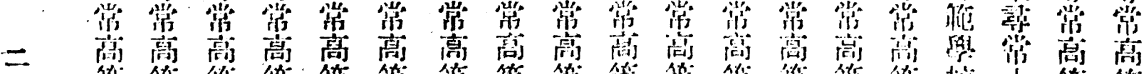

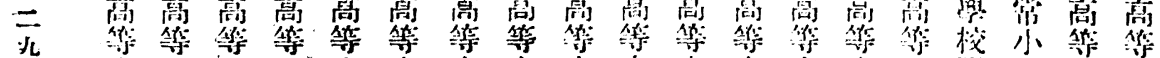

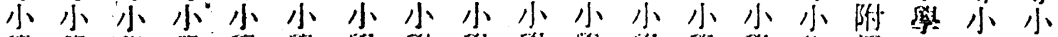

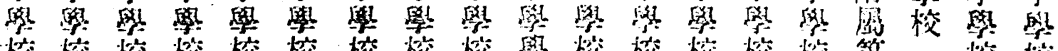
恔校 校校校校校校校學校校校校校第 校校 


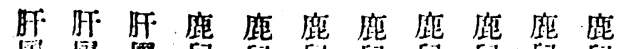

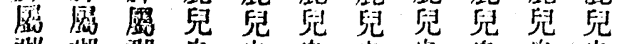

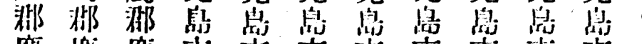

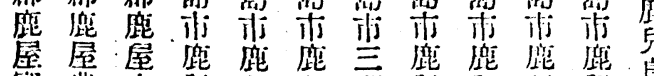

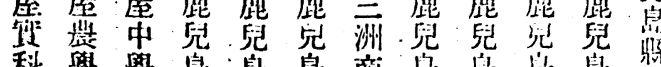

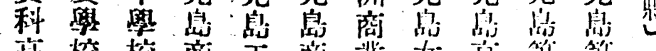

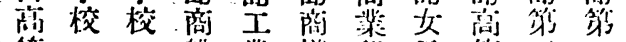

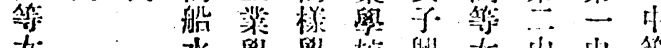

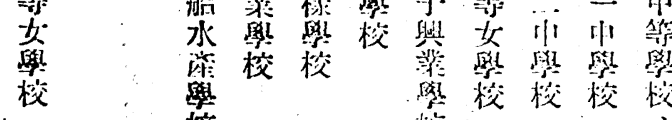
校

下閵玉阿阿侦

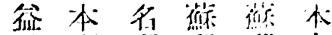

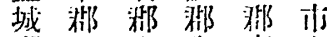

郡山大们高昘

小装原牧筷 日

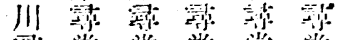

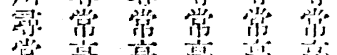

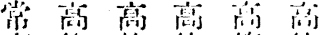

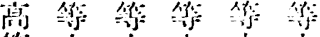

行小小小 小

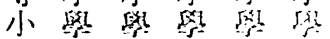

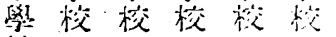

校

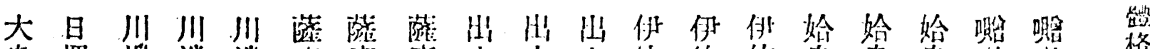

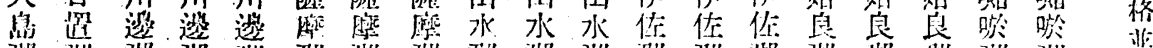

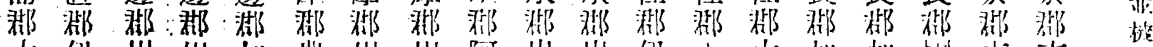

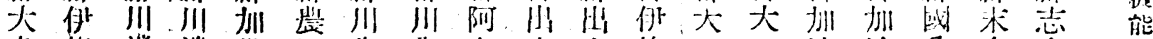

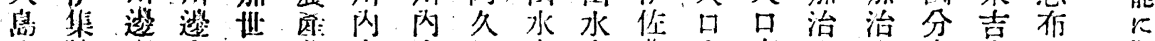

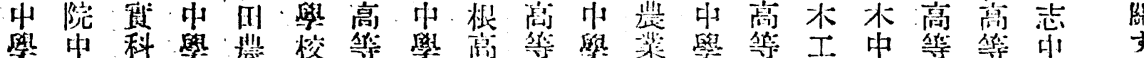

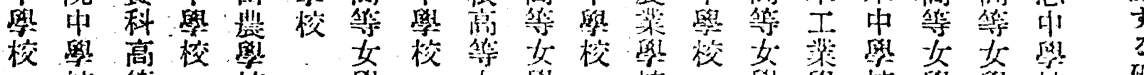

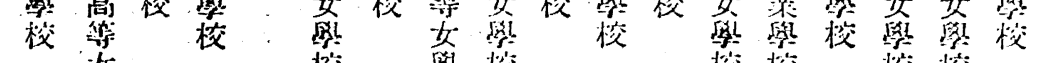

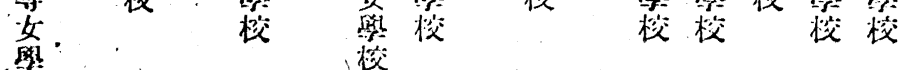

校

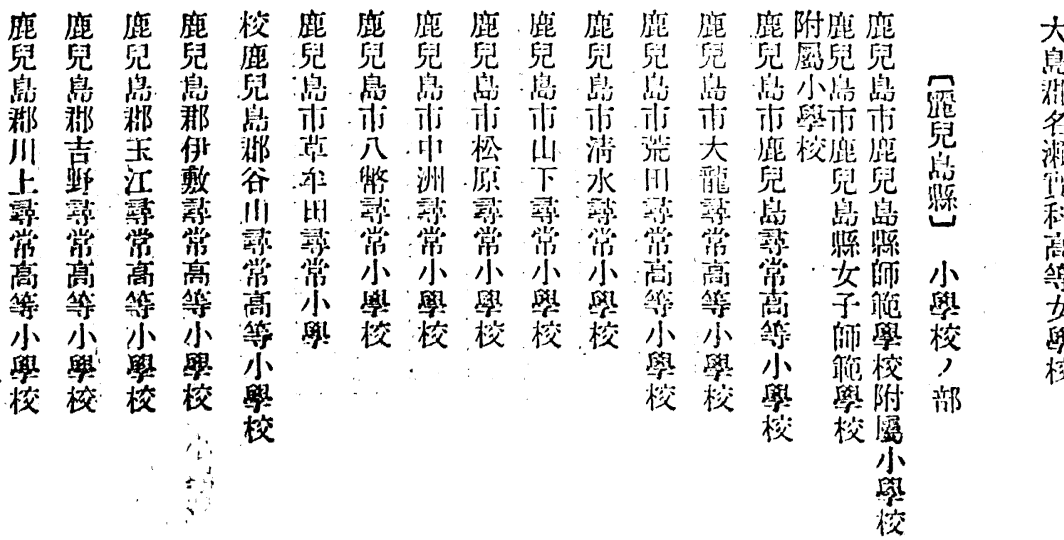

大

$\equiv$ 


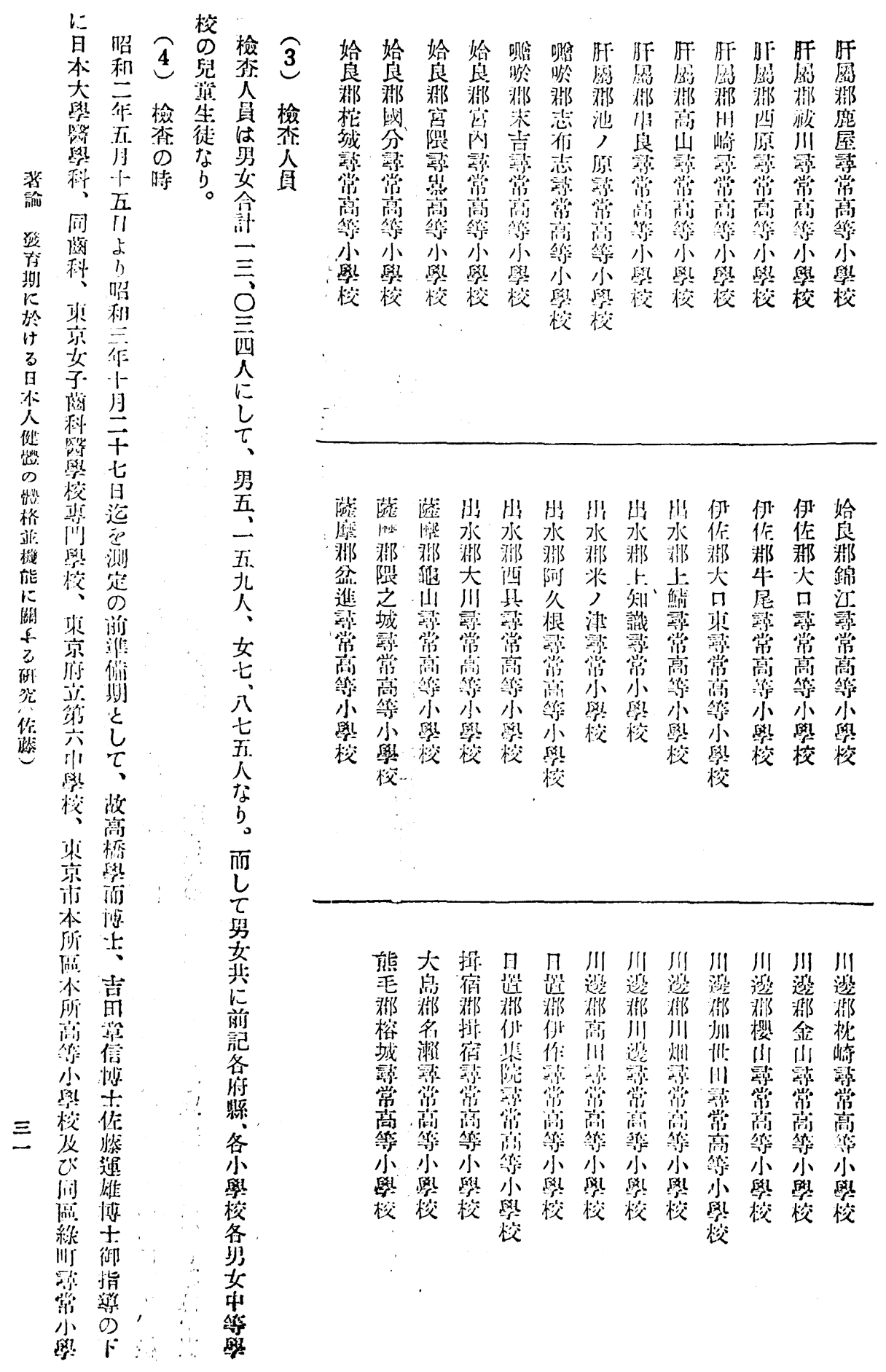




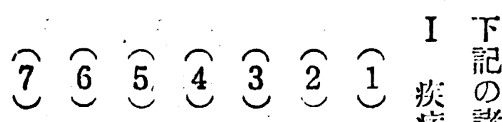

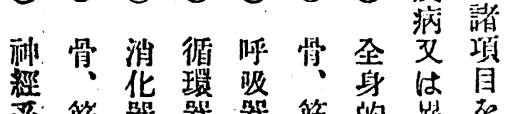

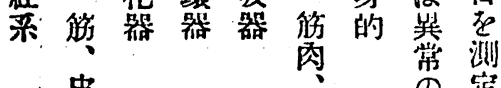

皮

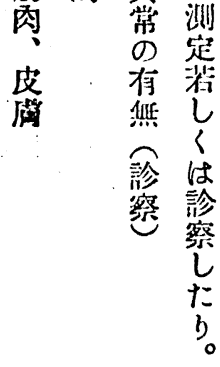

薄
省

す。杰前篮椋

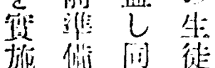

女

当被苝

柊检故

のて留就韭

敢榆就检

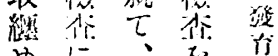

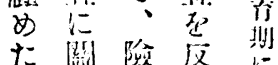

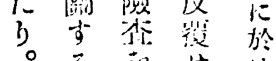

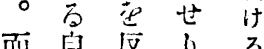

而自痽方。

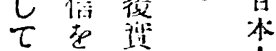

其得施人

粽江促

合、以

的態 $\tau$ 鼠

刵公同格

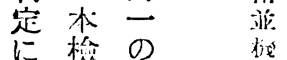

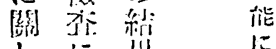

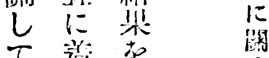

性挈得。

永世死确

非) 引 方

博弦努作

士

の 3

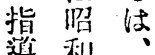

类 14 测

待作定

万四修

8 月 緗

の

多少提

加㟧徑

与利な

公

茲怔惫

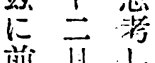

前的し

砸比

諸系れ

民るば

に绋な

對闬 b

ᄂ $k$

謝於

莩?

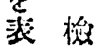




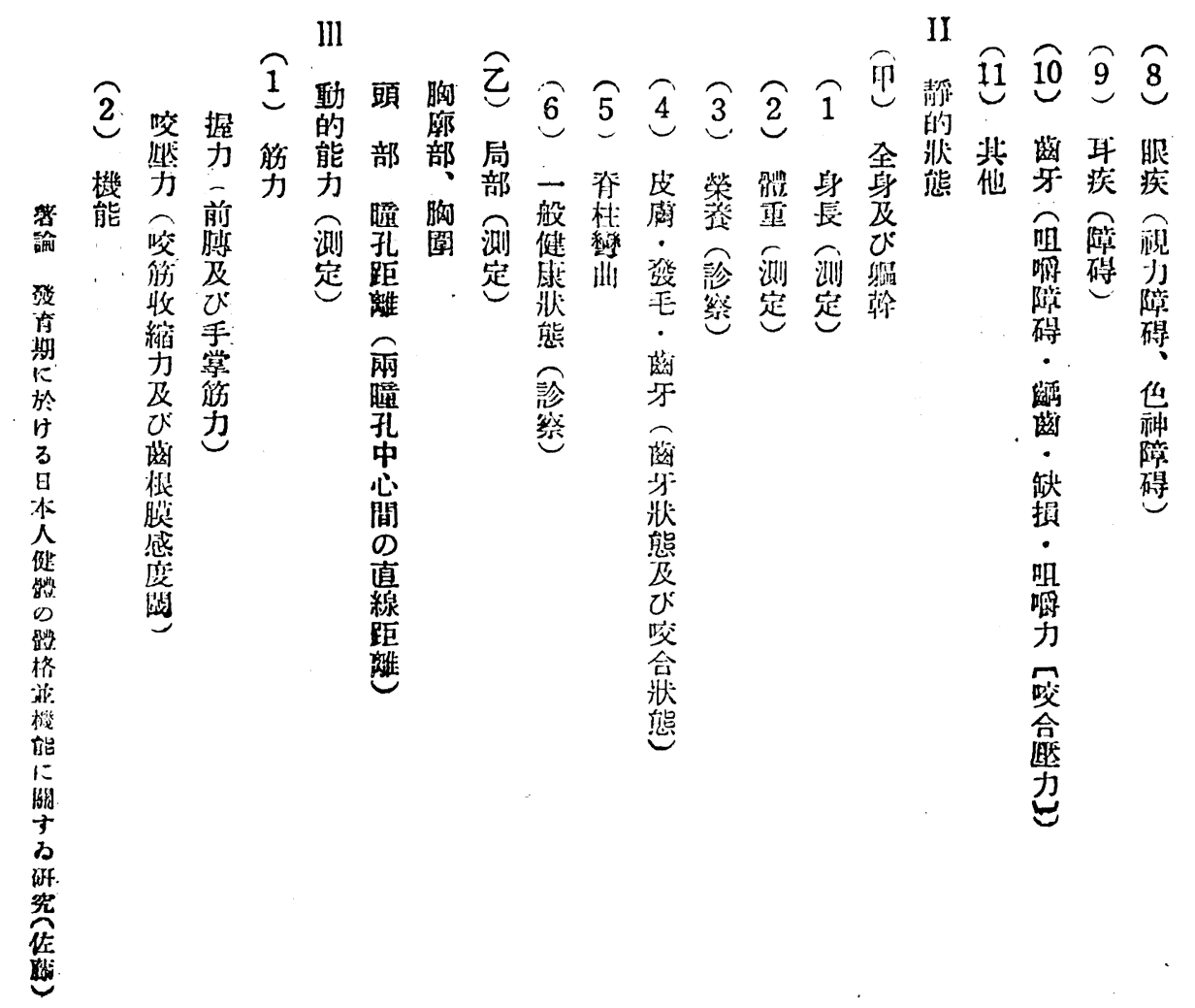

$\equiv$ 


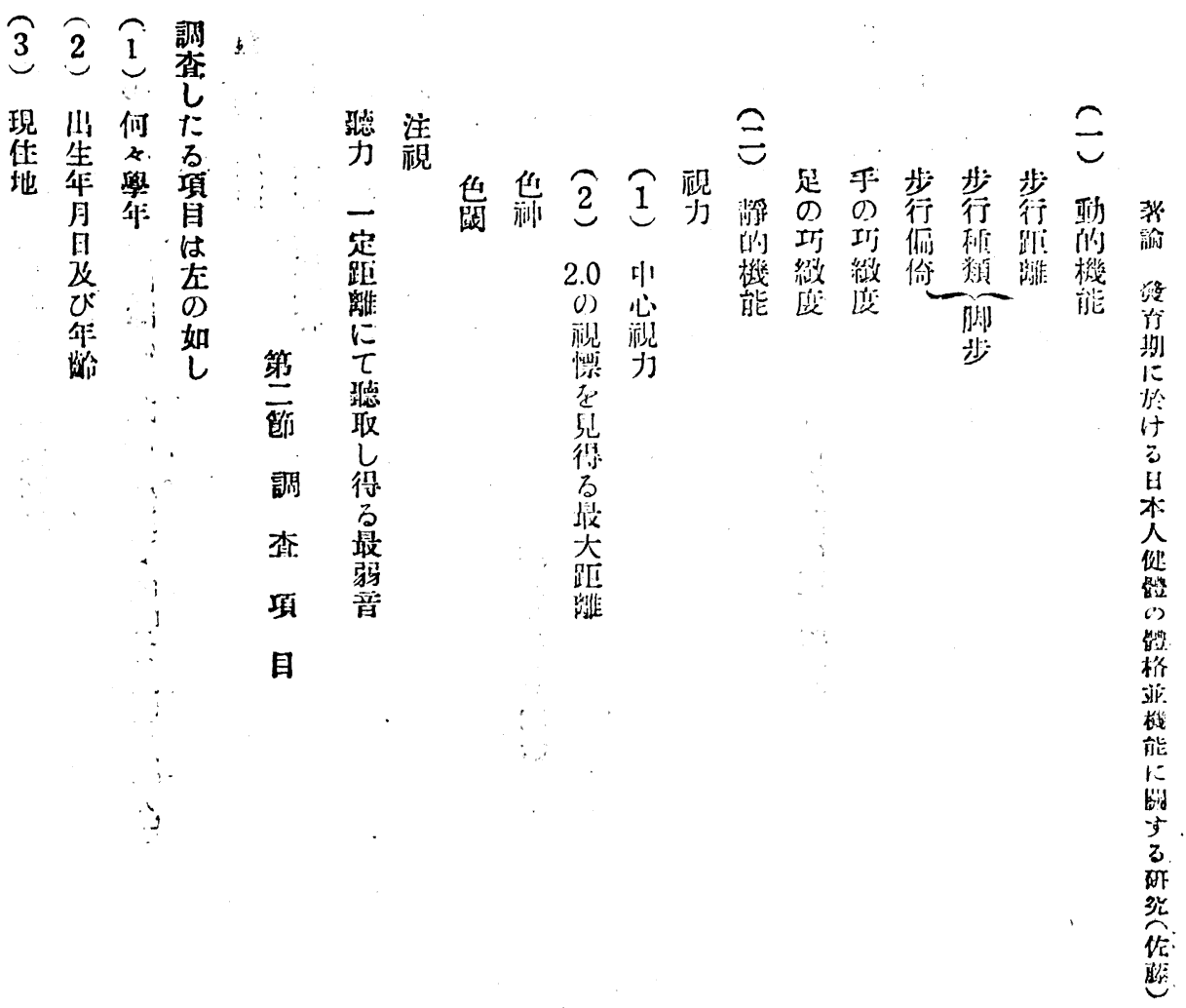




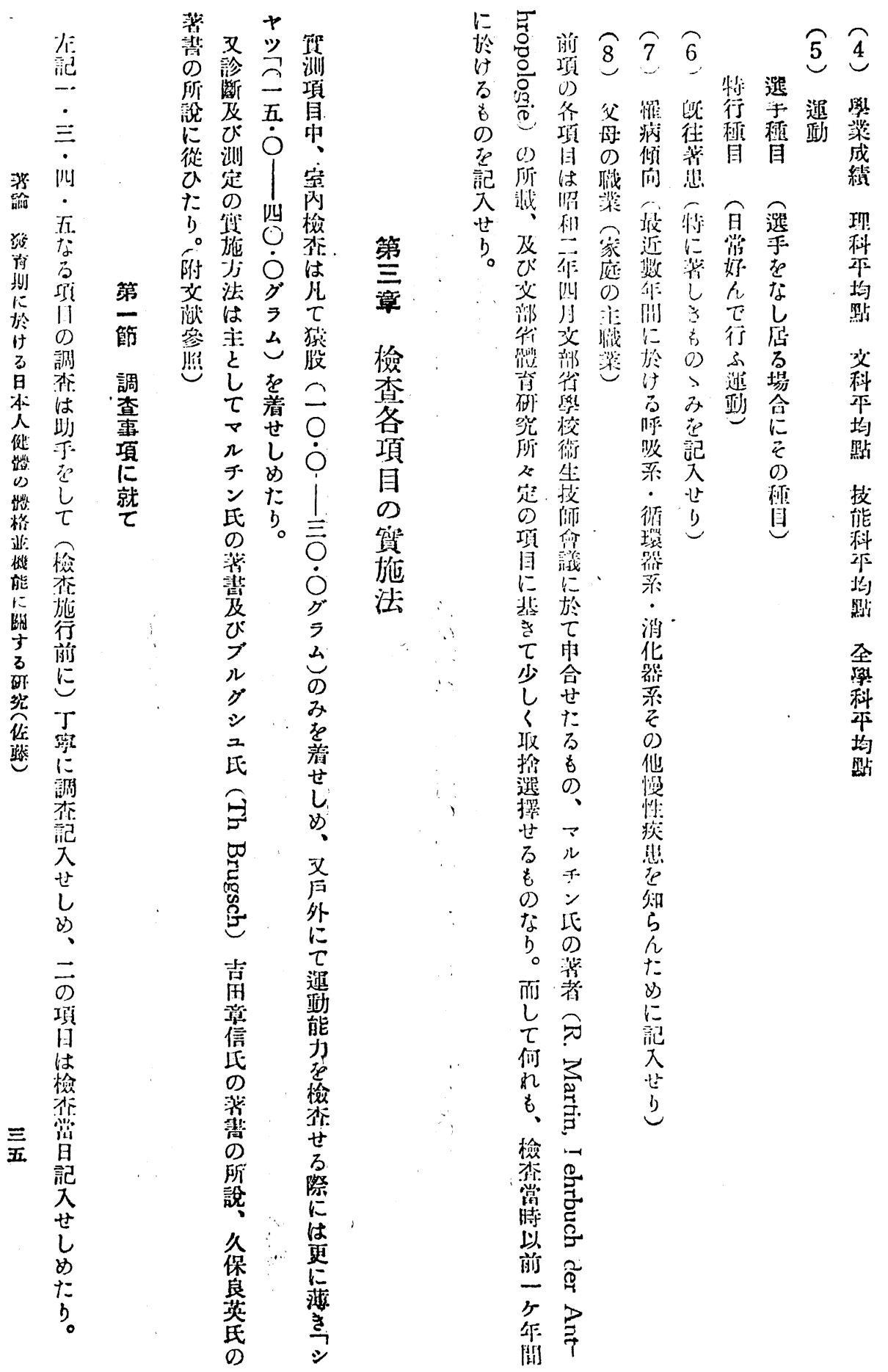




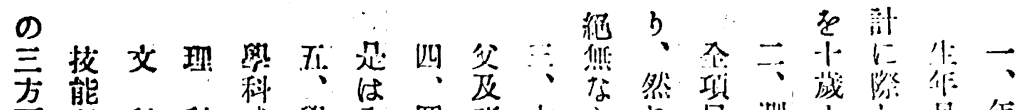

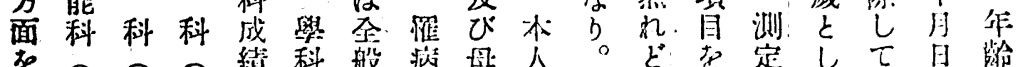

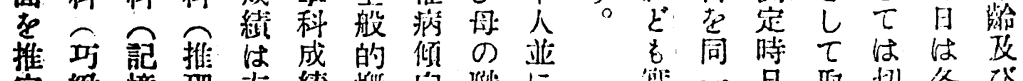

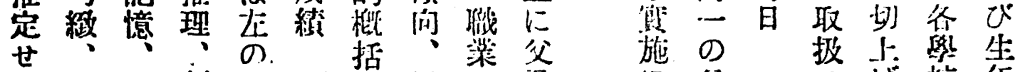

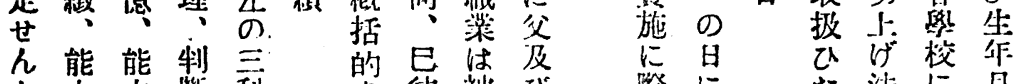

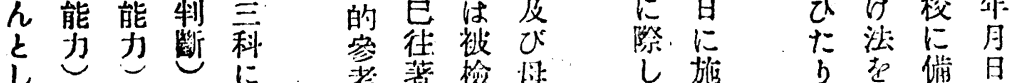

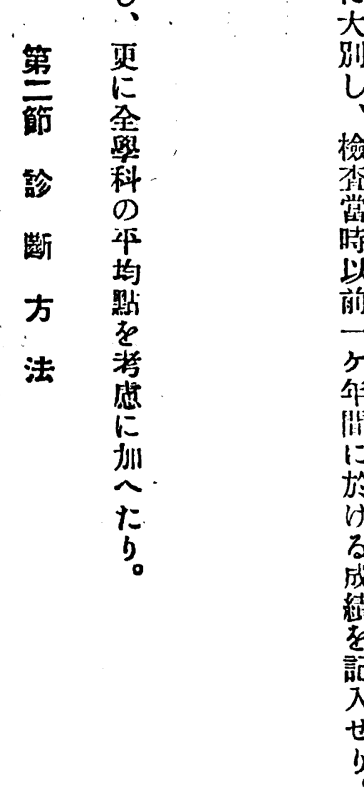

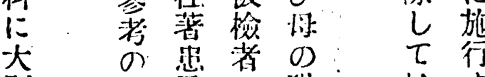

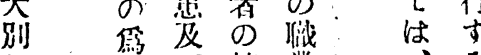

し、沙染等

檢䍀迎的现 $\dot{h}$ 本

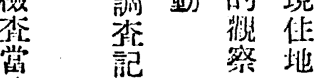

है 则

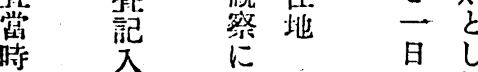

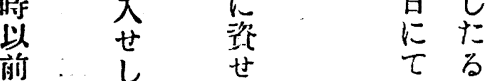

前 $\therefore$ し せ

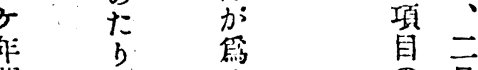

閏 ○ め の

。热偡 日

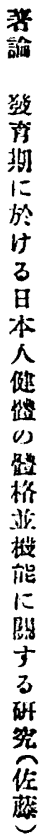

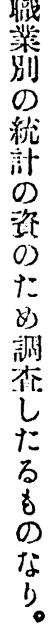

监或

ひ正は

地

i $\begin{array}{ll}z \\ n\end{array}$

保付

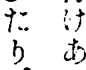

例舀

人籍本

ば渻俅

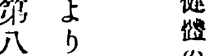

回㸃

の 戴格

告し。梏

5 ,

b $=$ 跑

别等

百

閑涉

に

沙

たあ

る る

棈

め称

稀 愁

E

$\tau$ 瓶

三人

儿 5

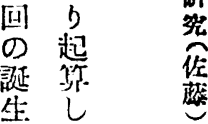

百所

觔 却

H

前 檢

前檢

比梁

涉

b) 所

放

吉

万現

万

है 蜀

は

者住

$\begin{array}{ll}\text { 无 } & 2 \\ & \end{array}$

祴 㵊

乙 何

一年

杂何

一 月

月 算

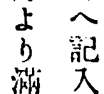

㪏

远新 


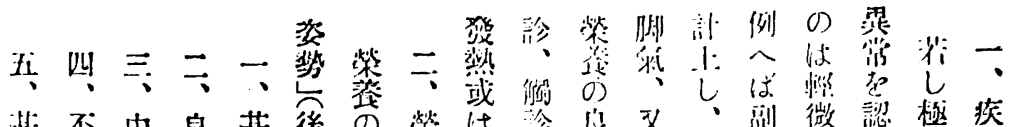

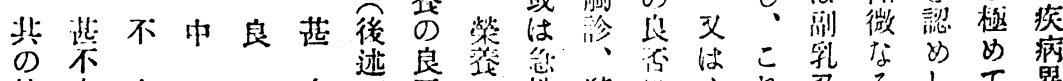

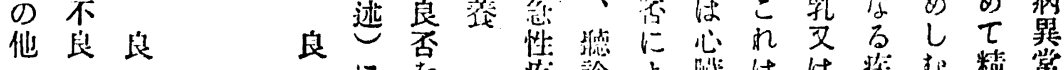

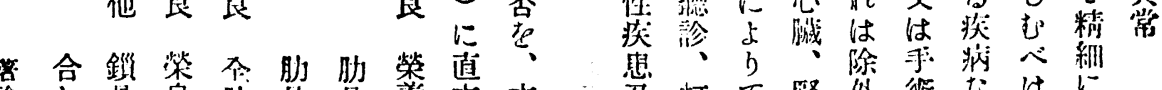

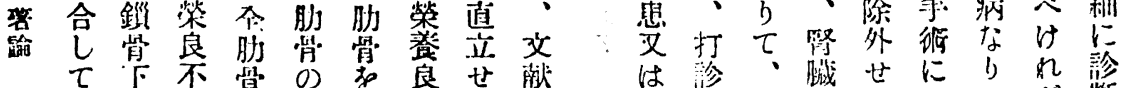

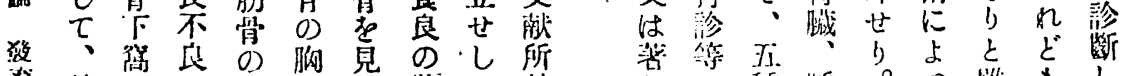

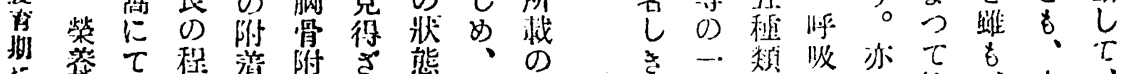

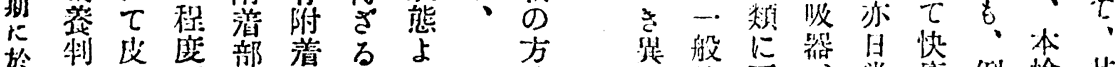

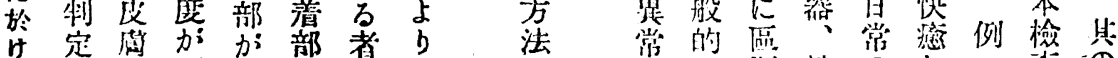

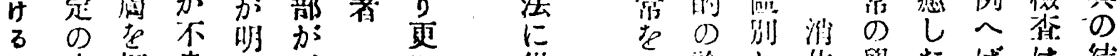

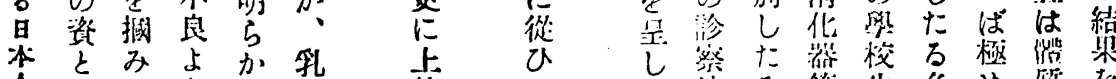

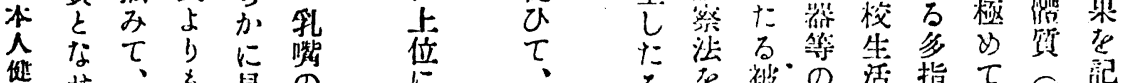

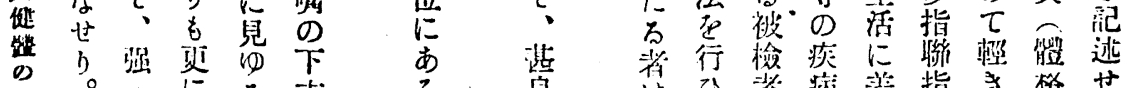

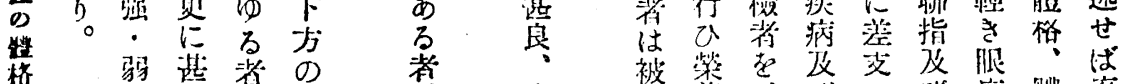

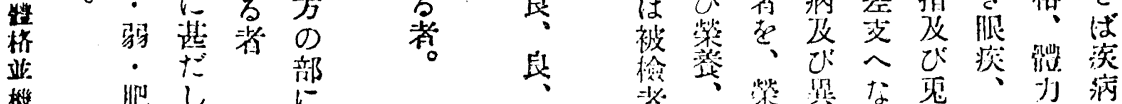

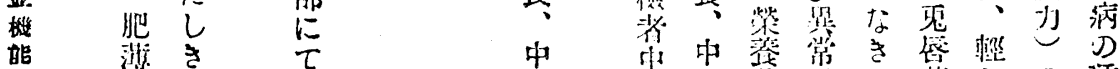

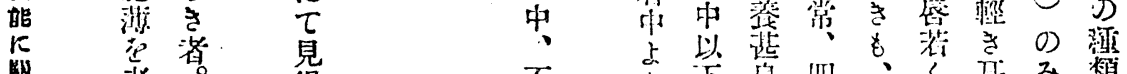

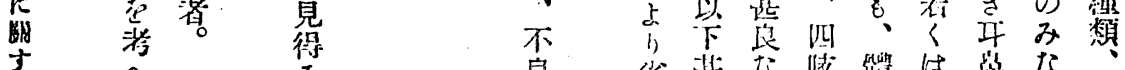

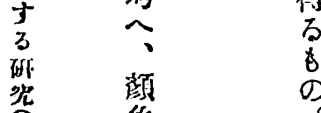

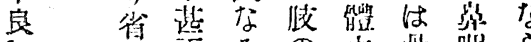

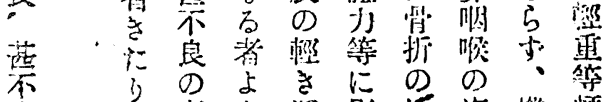




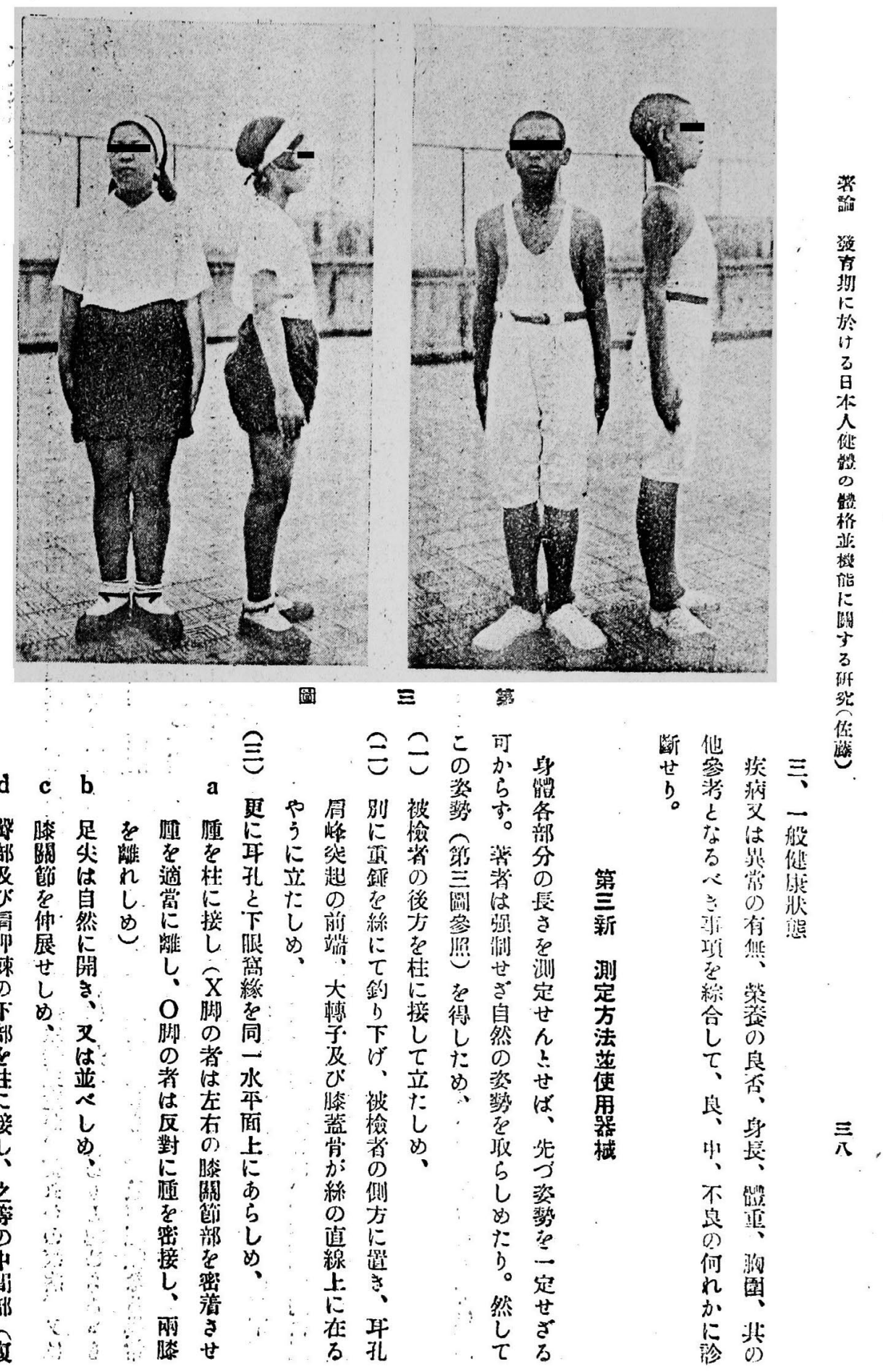




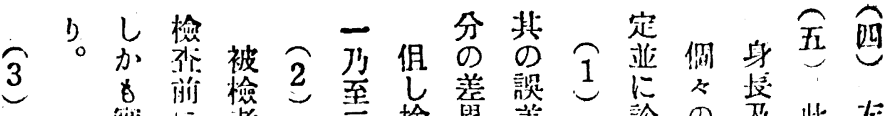

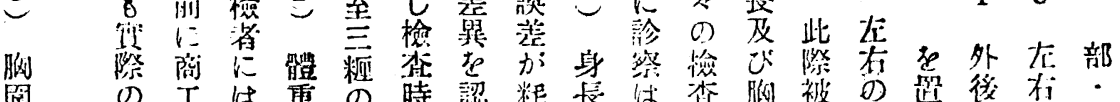

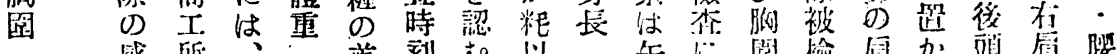

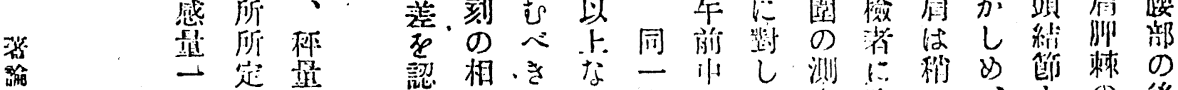

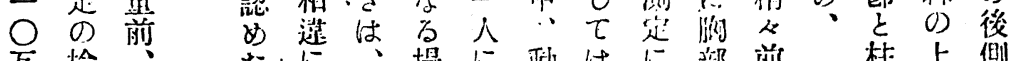

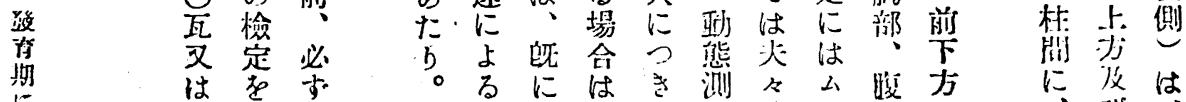

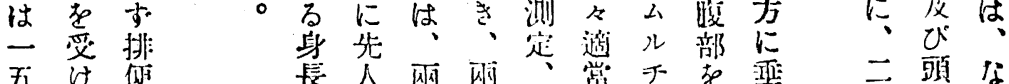

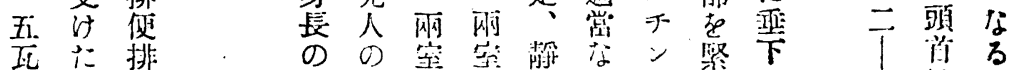

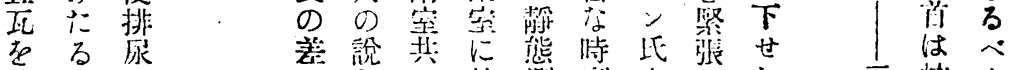

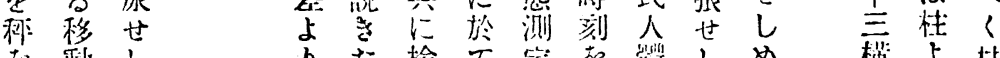

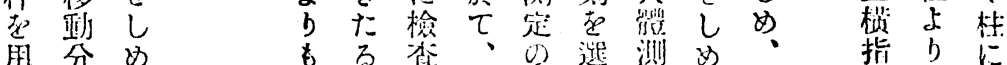

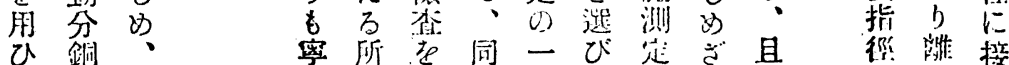

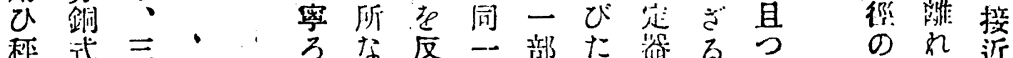

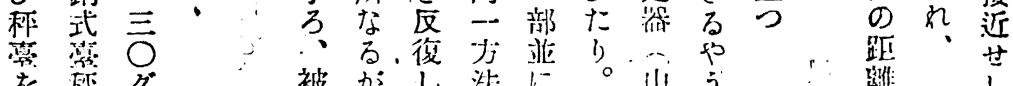

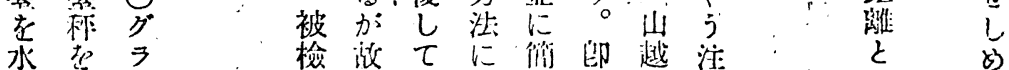

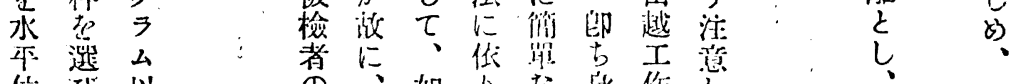

位び.以高如りな我作し

$z$ 内

し利 $の$

、量 猿

浆

中。 蛙

然望億

足は

(

棌

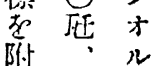

ᄂ $\overrightarrow{\text { に }}$

こ首腰

の炎部

部望㠅

に资は

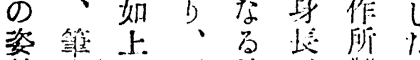

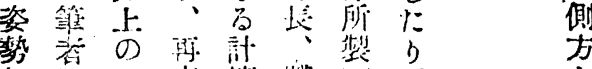

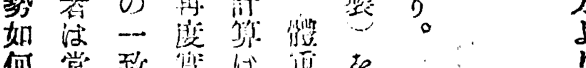

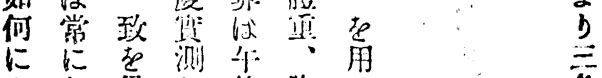

吉尔息し後胸ひ

生中迄籍行向

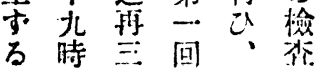

變上检 O指住

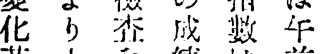

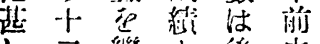

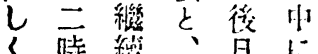

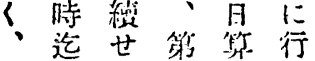

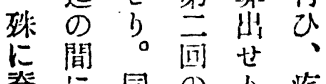

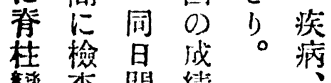

俔

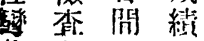

㤟荇卡市

$\equiv$

襝 $\overrightarrow{0}$

万吃均

老聚檢

咅度舀

の時值榷

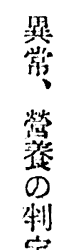

依 》

瓷等

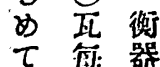

和に

亚

管射。

踊

蓀留

定

㧒

耳

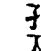

发

眼

裂激

の

等 


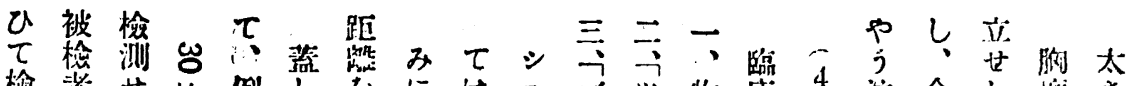

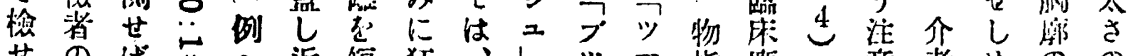

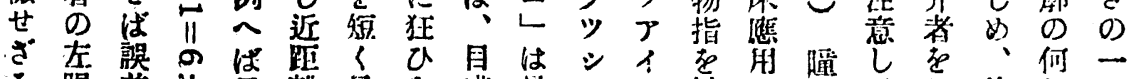

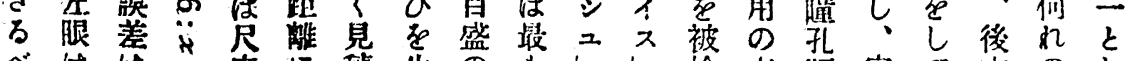

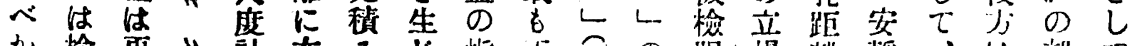

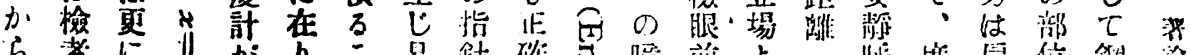

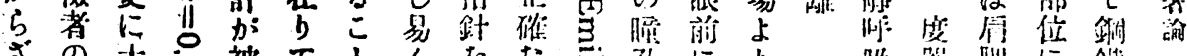

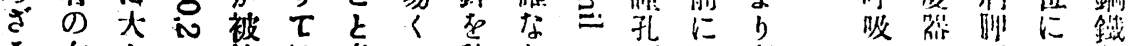

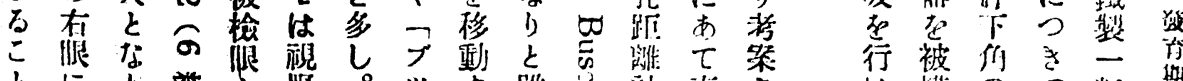

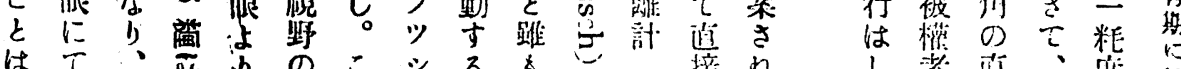

はて

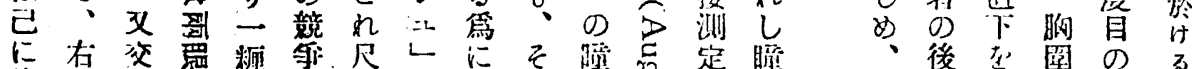

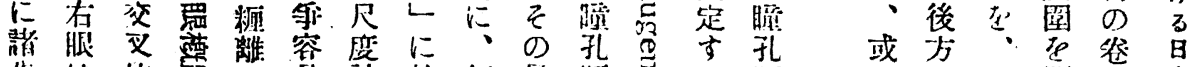

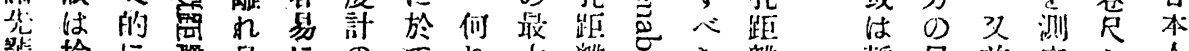

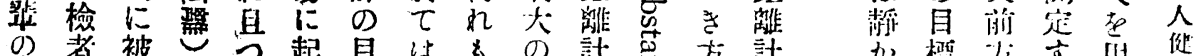

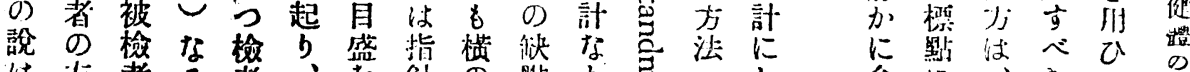

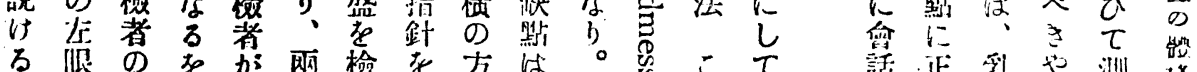

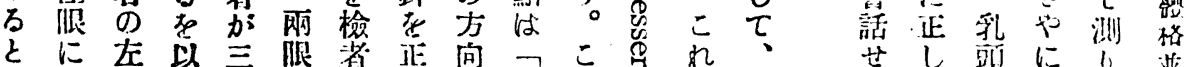

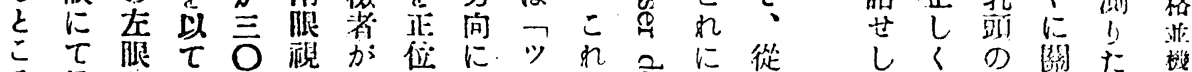

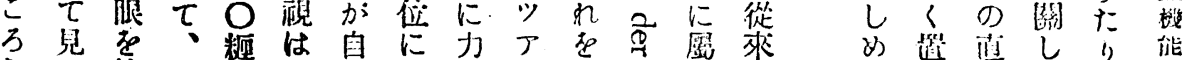

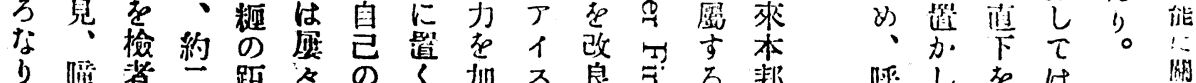

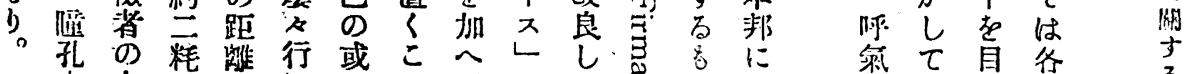

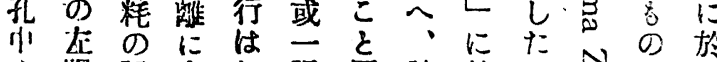

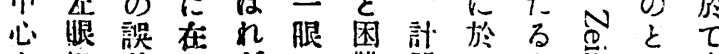

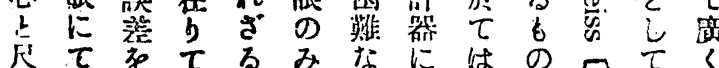

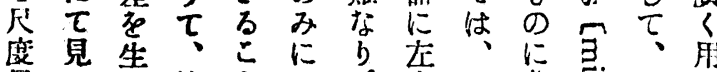

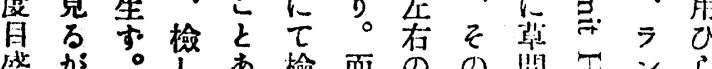

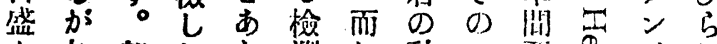

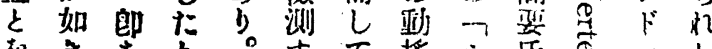

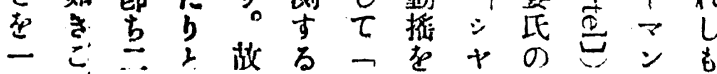

致 $九$ 糖せに加二與”㧧试の

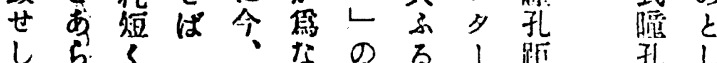

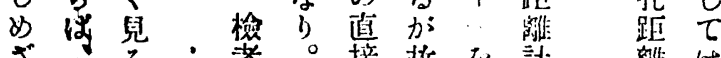

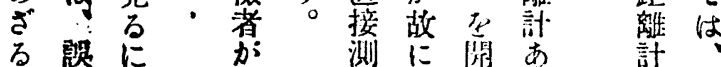

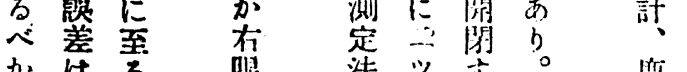

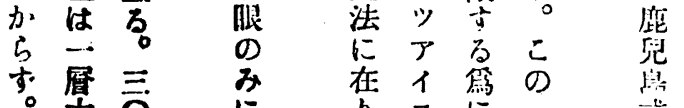

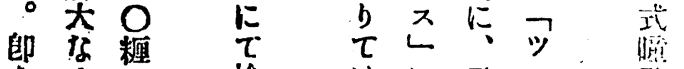

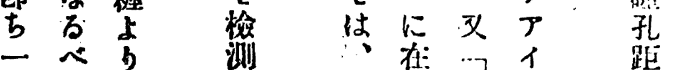

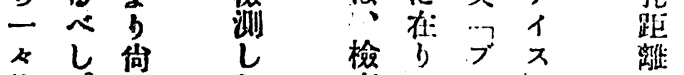

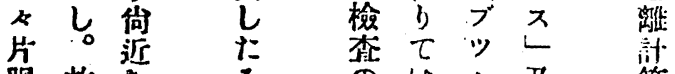

眼故要当等

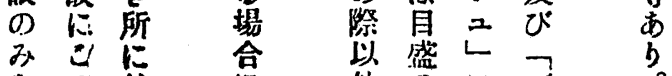

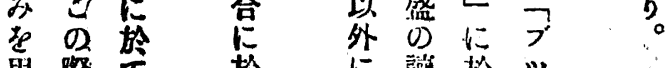

妞宁息各吉

吸檢 $\varepsilon$ 者研

萧省等焦

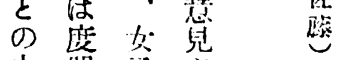

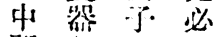

間在 0 尔

に前鲌 し

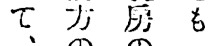

○) $\rightarrow$

呼测排

昨然

迎邑せ

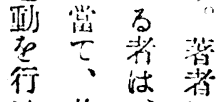

峈此乳少

哧際縞

测檢留被回

足に助檚

也的阔

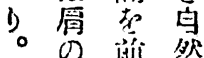

步方

吕瓷

さ標品

万直 


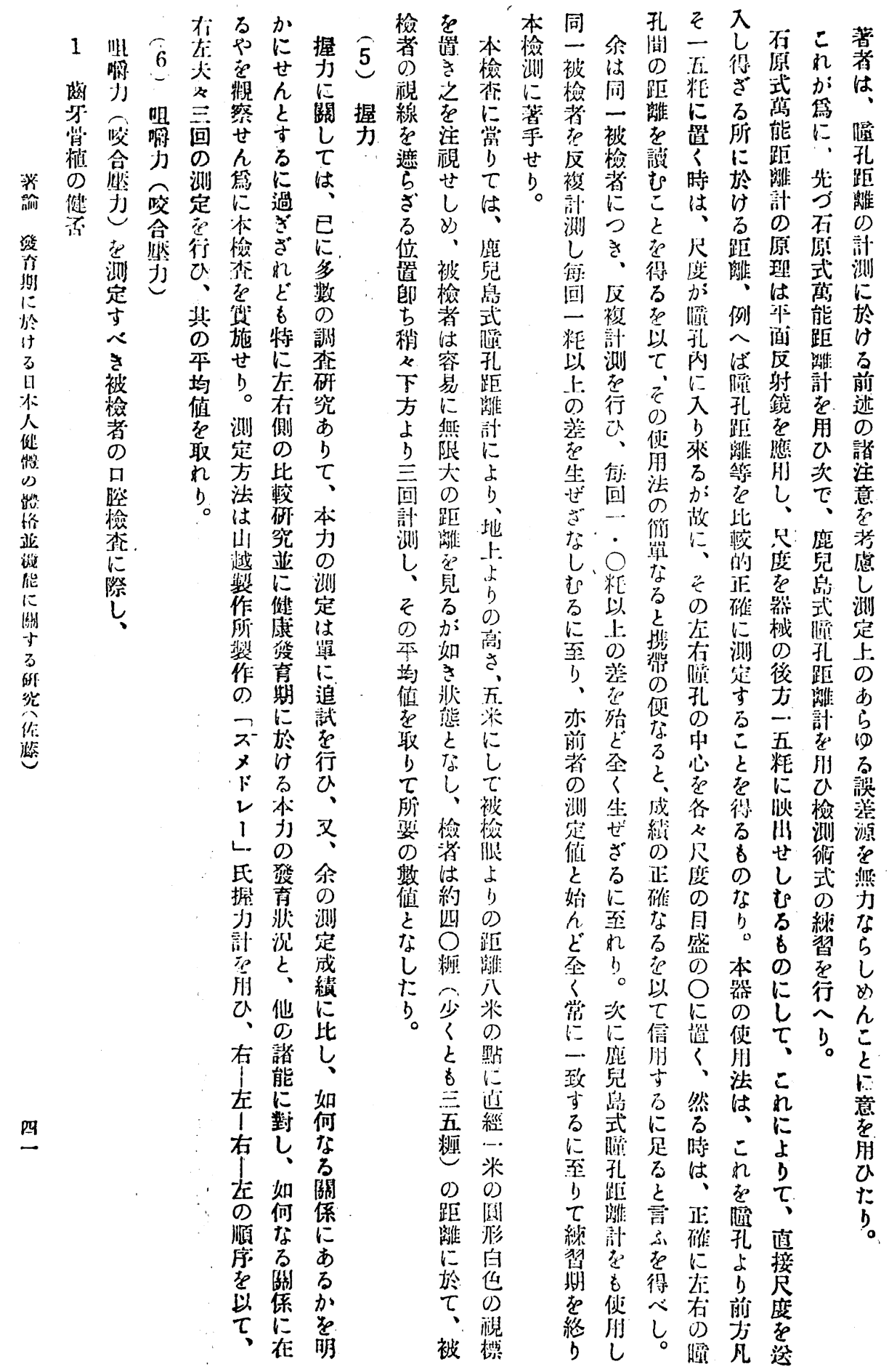




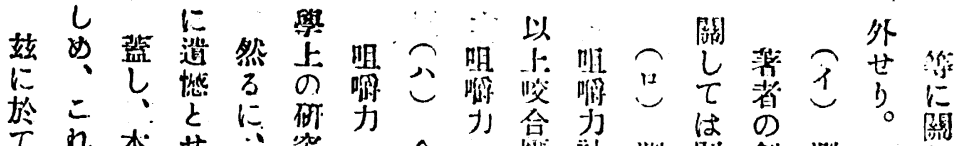

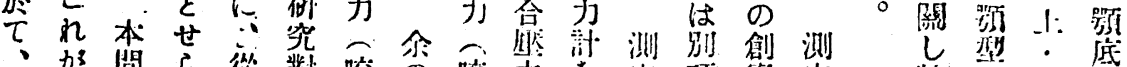

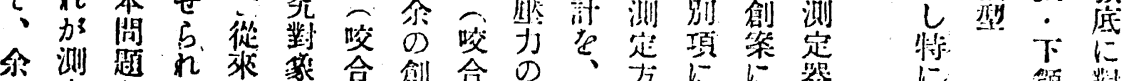

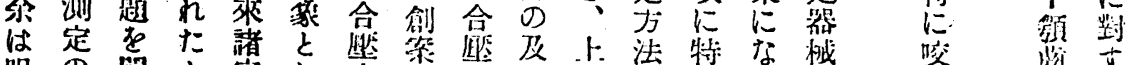

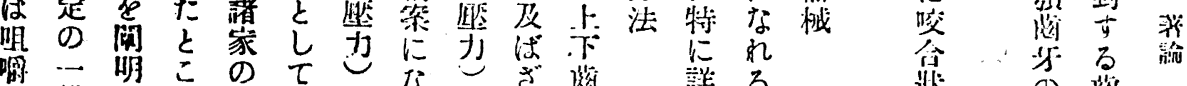

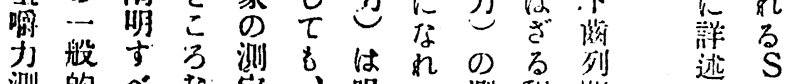

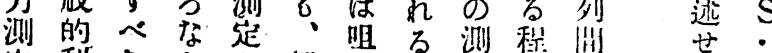

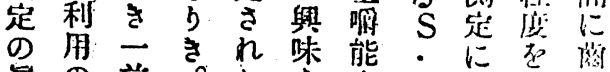

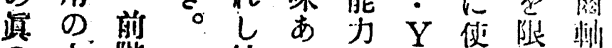

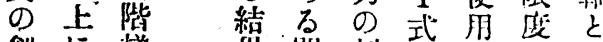

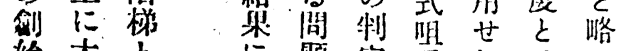

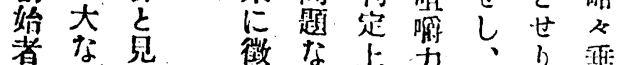

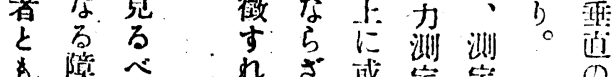

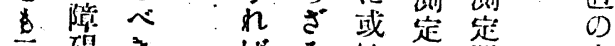

云碍き估方参器器方

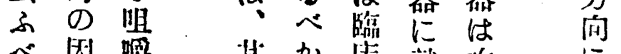

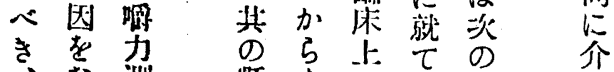

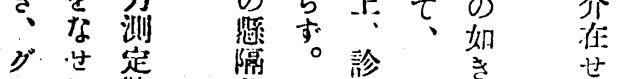

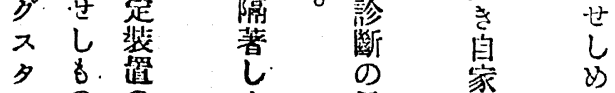

$19 \%$ 具家

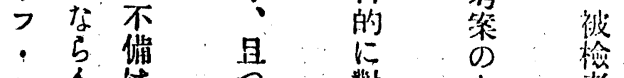

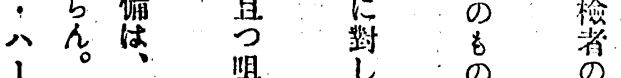

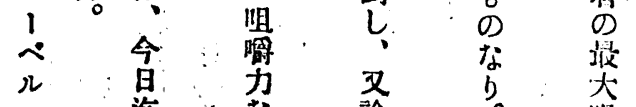

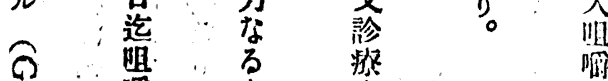

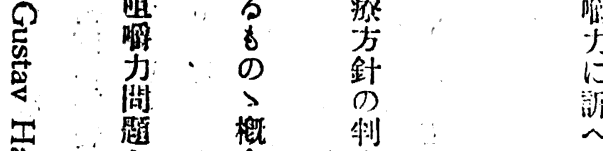

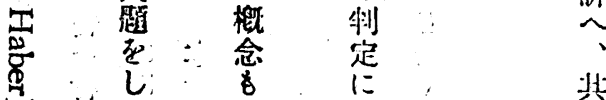

次 $\quad \therefore \quad$ 板

力 $\because$ 定 $\ldots$ 極

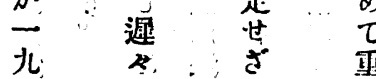

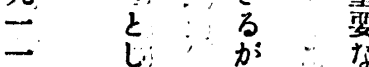

作记如

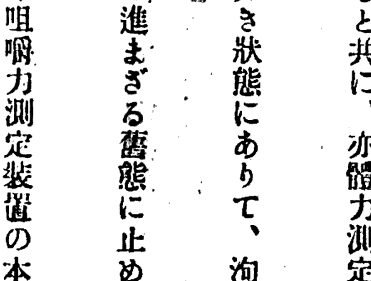

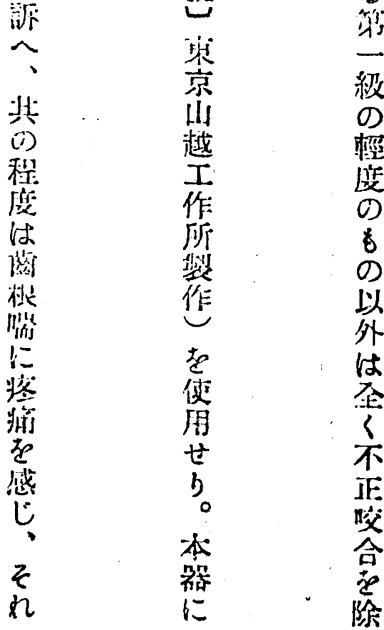

0) 謟

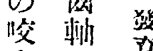

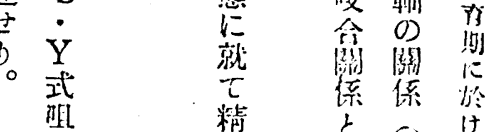

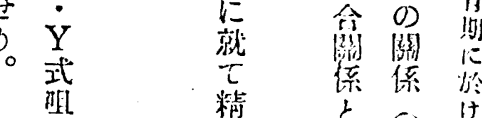

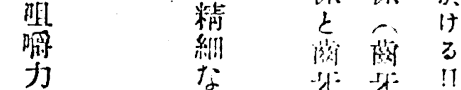

公等势和

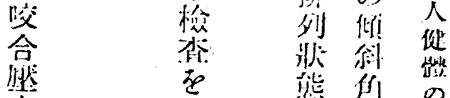

吕行柋们口

度箖

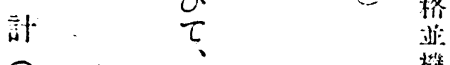

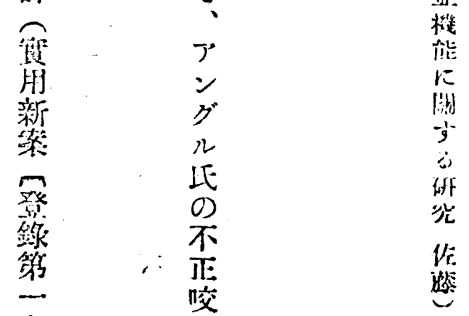

沶

拿

颣

占

回 


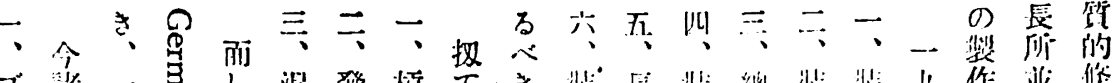

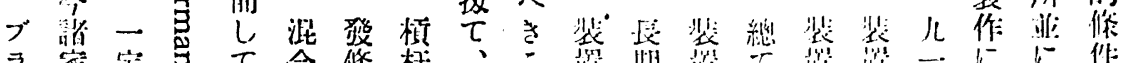

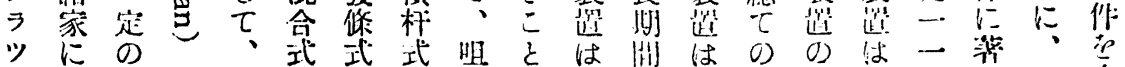

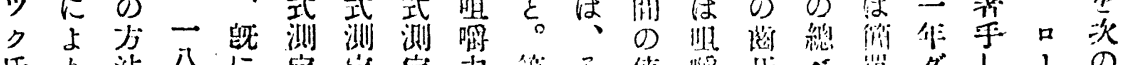

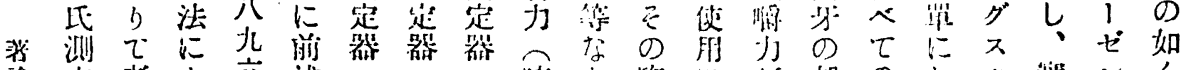

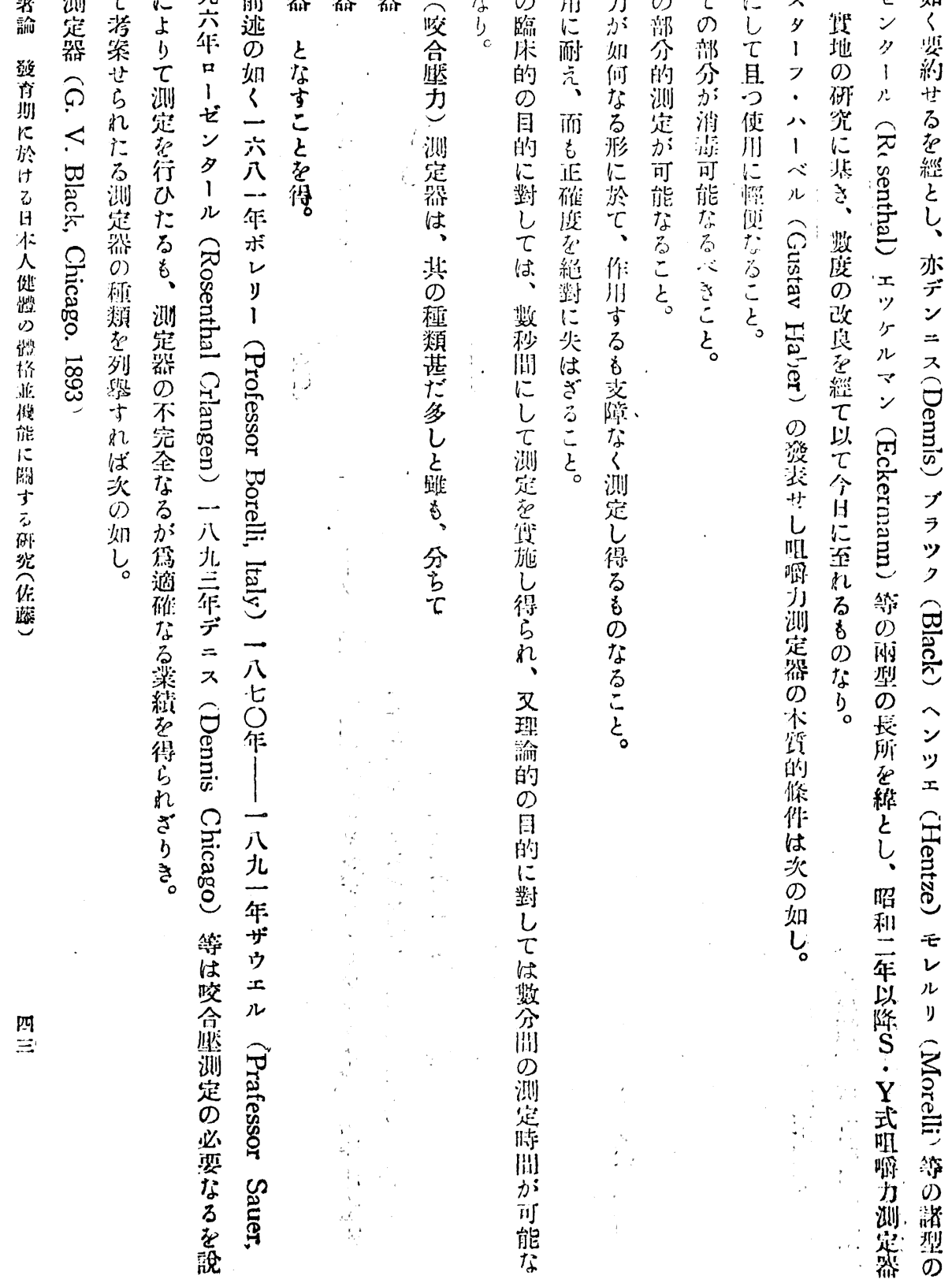




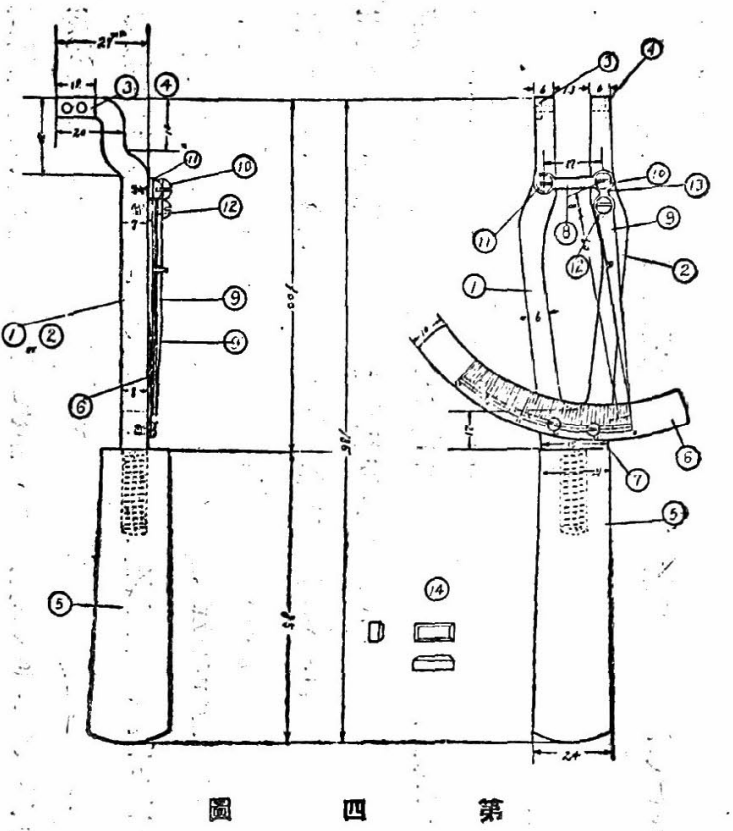

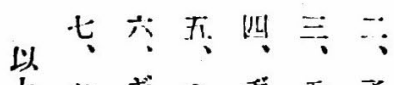

贞へギへヂモナ

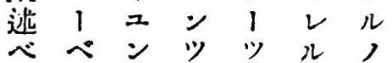

た

当的氏民亦

测测 氐测测 测 氐

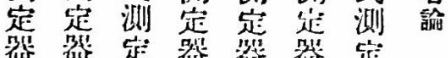

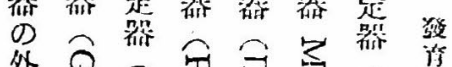

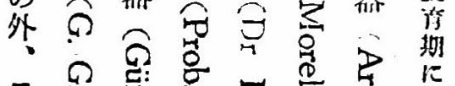

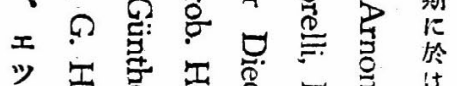

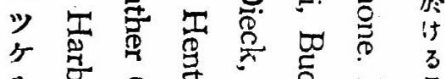

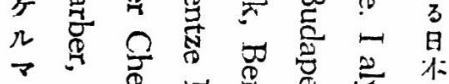

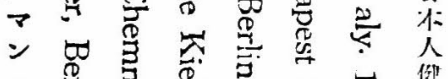

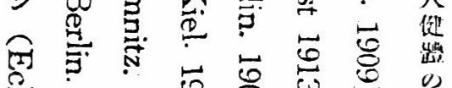

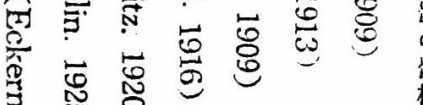

常

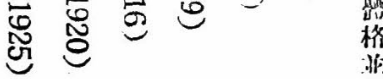
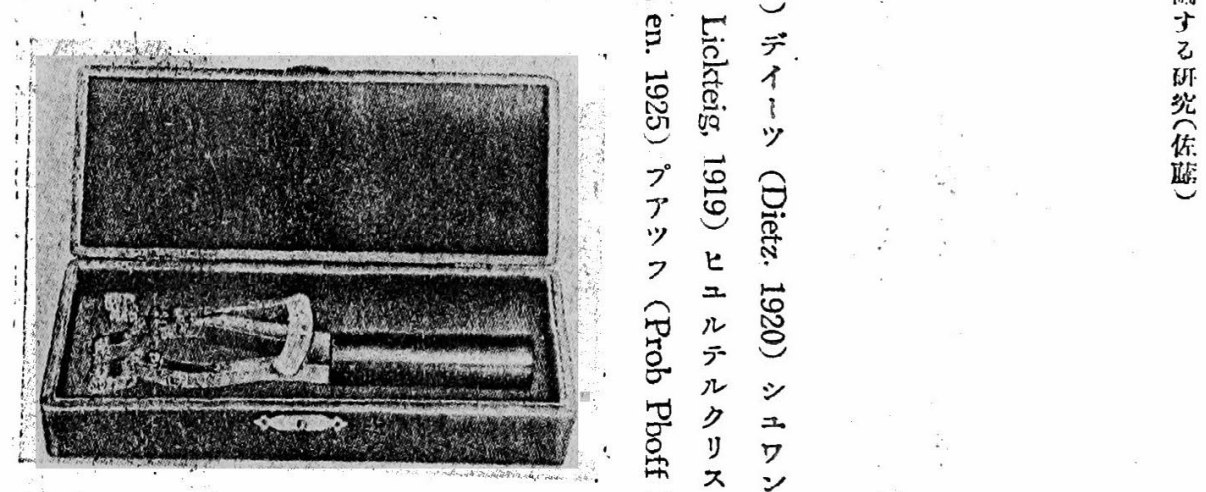

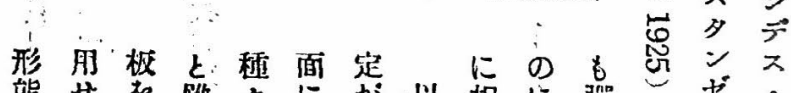

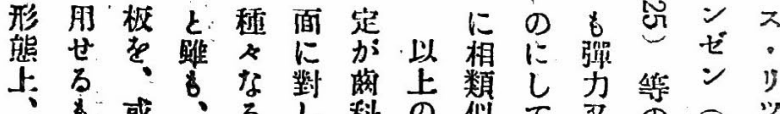

咬 の は殆测、治如世似文

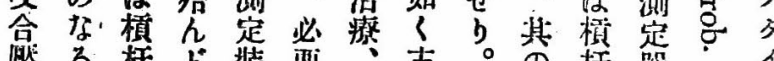

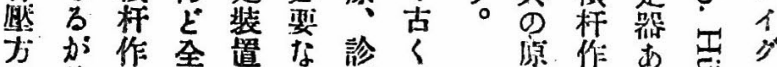

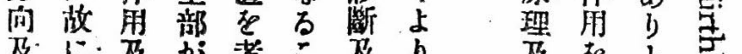

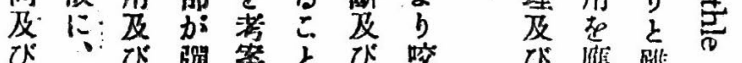

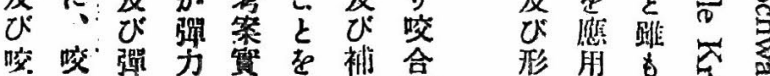

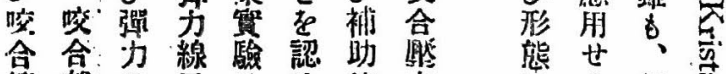

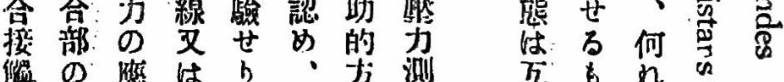




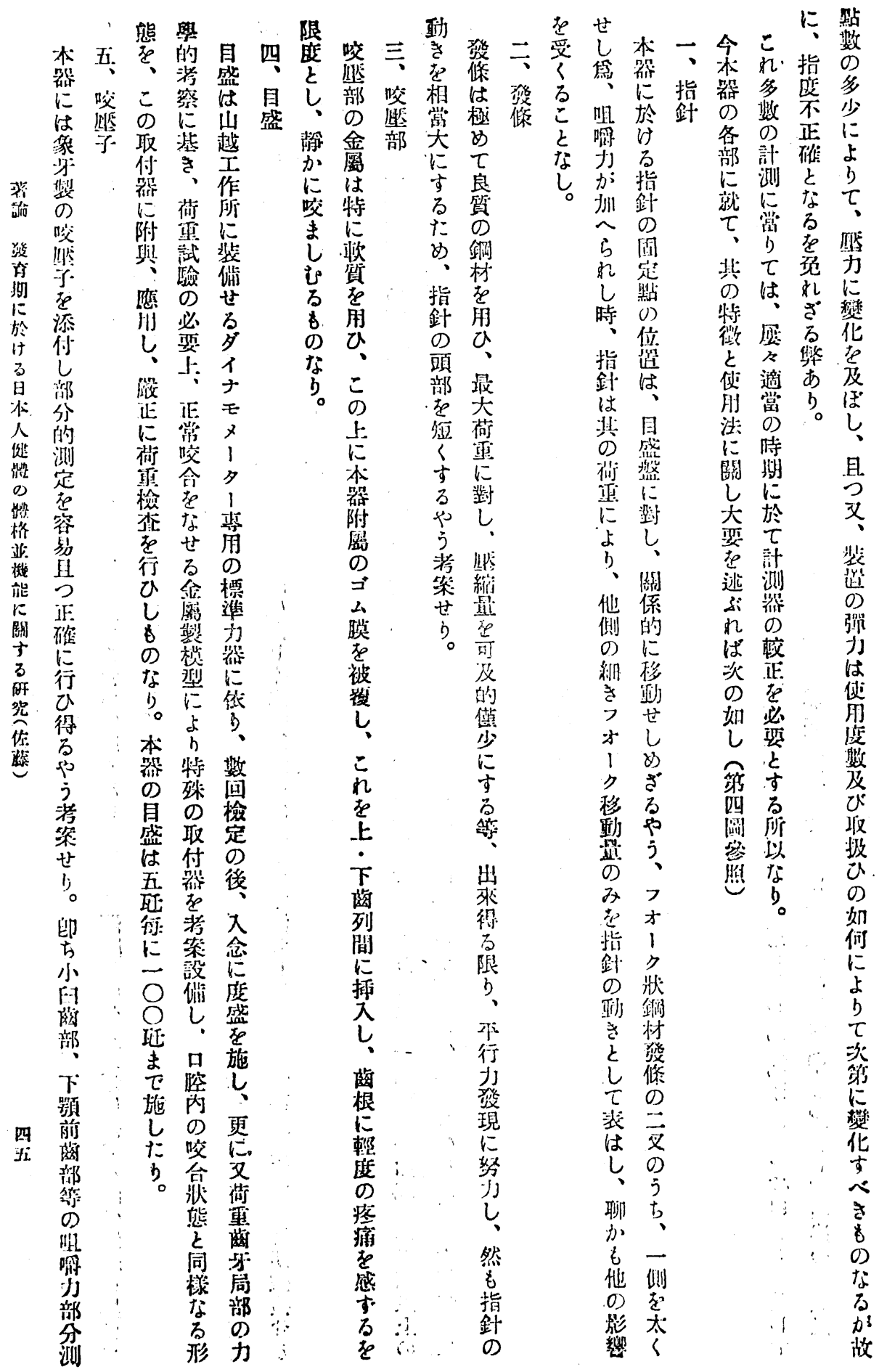




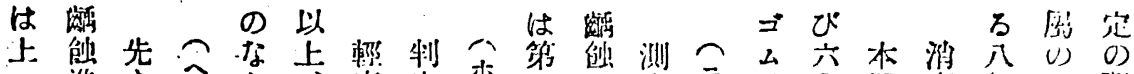

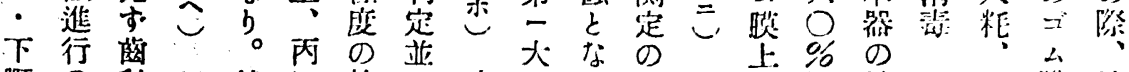

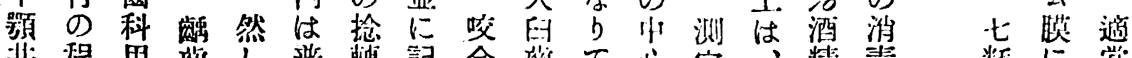

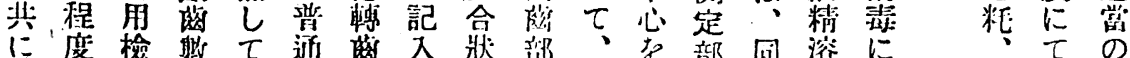

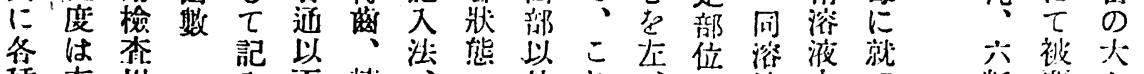

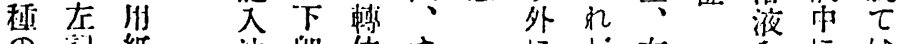

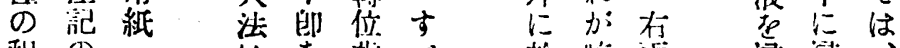

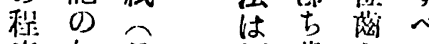

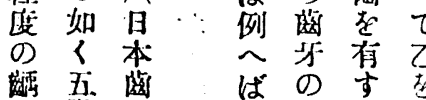

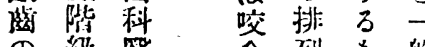

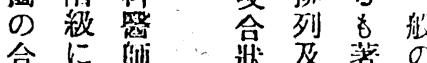

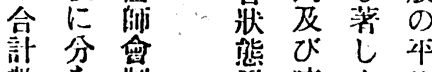

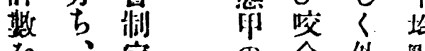

农、定・ $\sigma$ 合外點

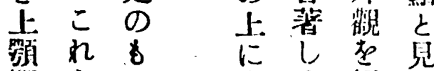

榴尼の: ○提做

下槛蛋 印不せ し

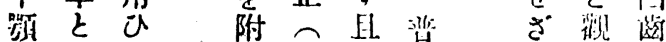

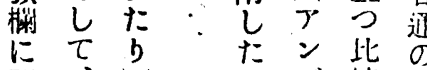

にてり記 た た

罂例に。的態

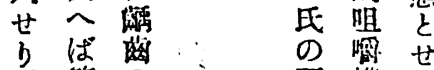

。第罗: 不機 り

位話

洔從，盒磉
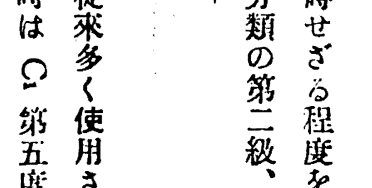

吾柿等

o $n$

第 丵

時 $ᄂ$

视 0

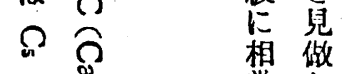

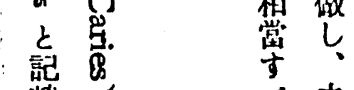

㳦

しを き

许牮

出

の 检。

正:

查然

表它

咬

合 甲

な は

る. 帛

苚 侧

测少行

七 影

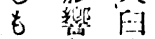

0) 管四

如乘泳

尖め

紫莎

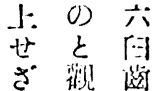

万然部

己. さ

得合

時相

估测

篗哲

天噽

自

比

部”。

於 さ

管 d

测

这第

行 大

ひ

ᄂ 遴

\% の

の 趹

あ 如

虹或

岁

本管

せ 岀湍

球咬特

兴部注

活 被 意

拭铰世

す。

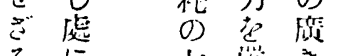

䊉筑 さ

菜

粍行间

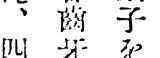

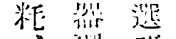

三自筧

糧自咬

二盄照

麊唯 子

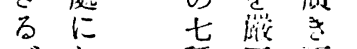

ゴ ᄂ 稩 正: 面

厶 $\tau$ 居惐

蓝、作测神能

は印成贸分

京古深守蛋

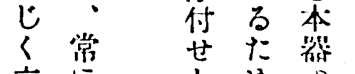

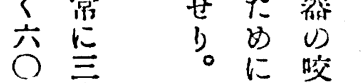

$\%$

酒四

料: 組

出筫

方部

涳 9 ह

0) 茨

出测: な せ

浮 政

游用

せ 意

(๖)

测 各

紫 ㄴ

は 体

检必㠾

又 答

㖫に

些 際

都它

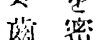

筫 接

に

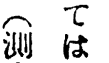

揬 し 四

突

万た

面 2

の 咬

及 $\dot{y}$

短

報 期

び 1

經 分。

告以

に卡

被光

せ 液

の

留占

守附 


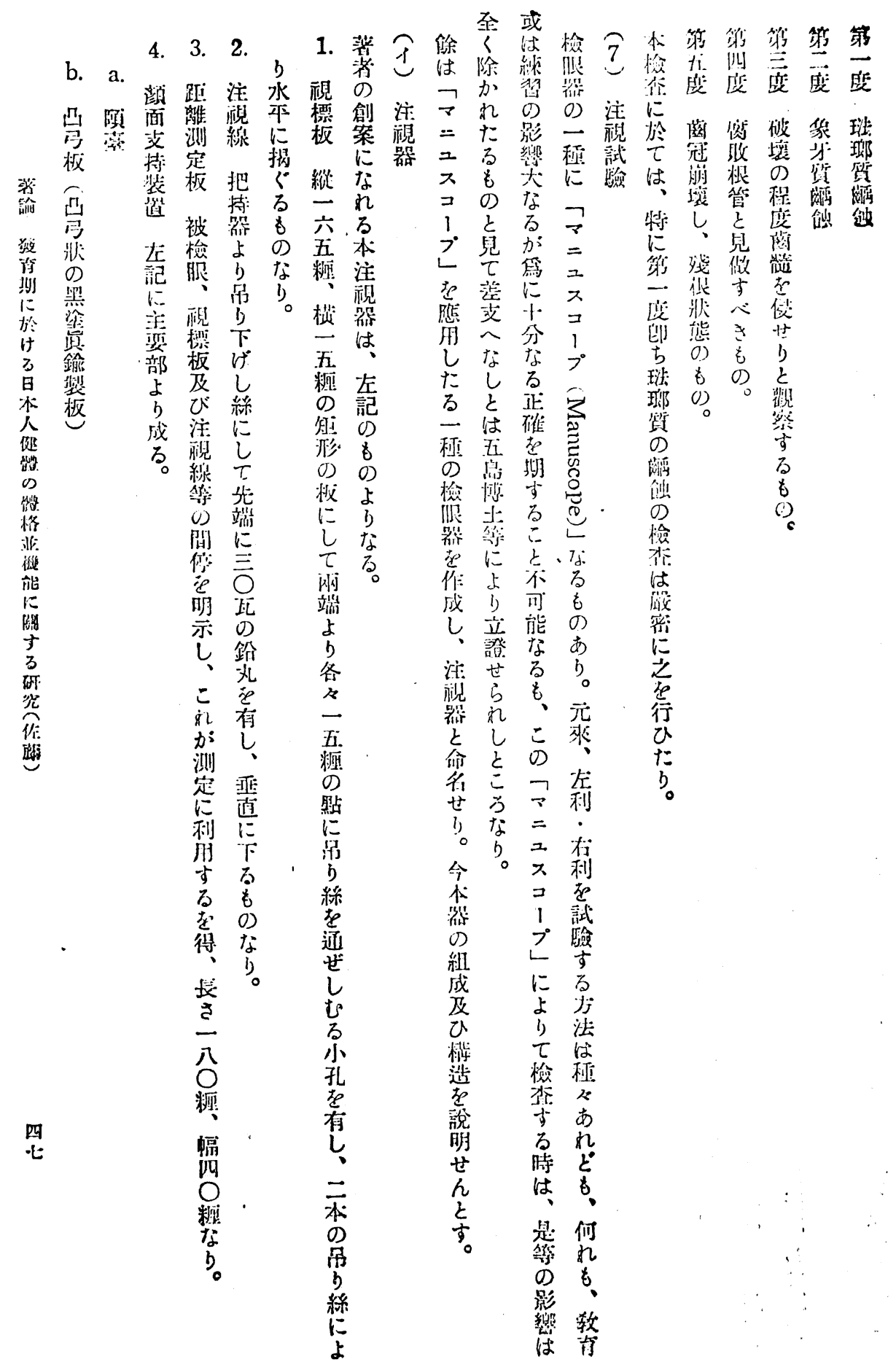




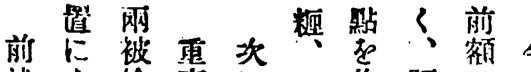

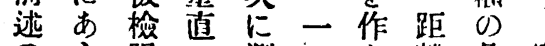

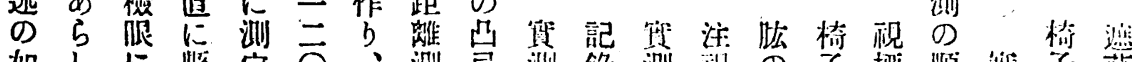

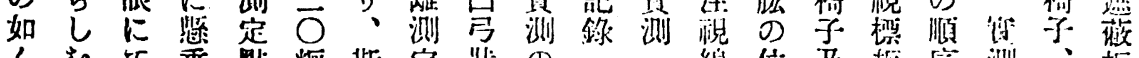

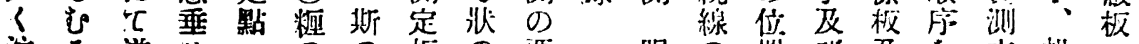

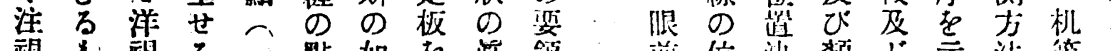

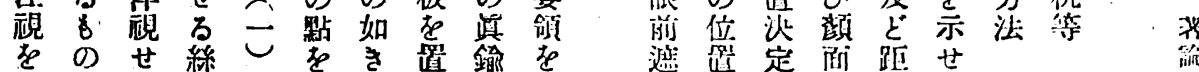

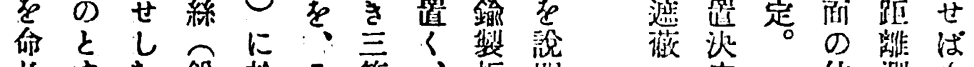

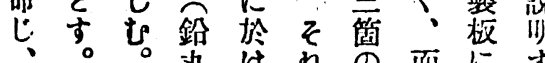

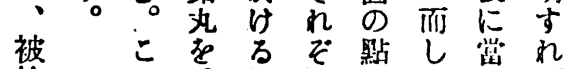

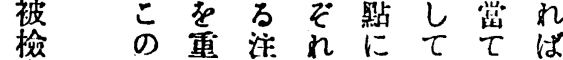

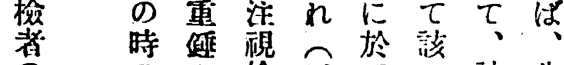

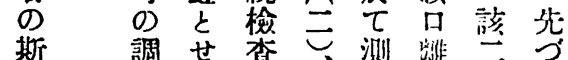

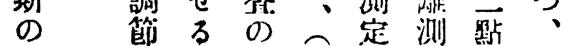

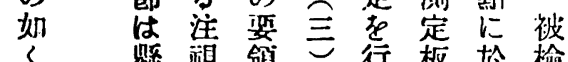

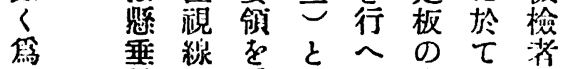

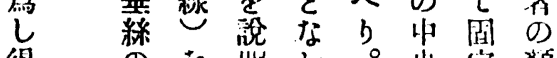

得 0 岄し。炕定颜

た在尔亦た测印古面

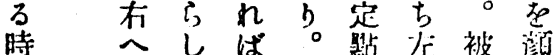

は のめ吸检面

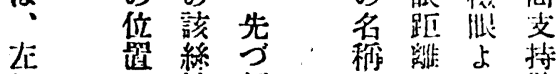

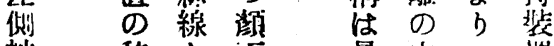

被移々面最中一选

检動: 支

菛視持。被は○间

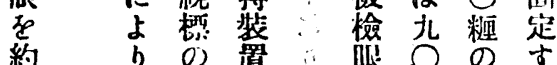

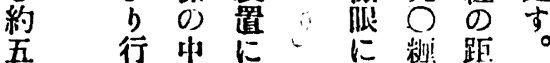

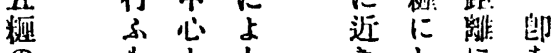

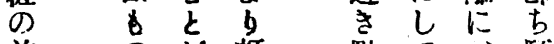

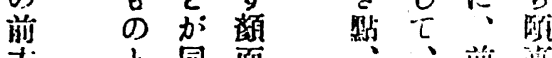

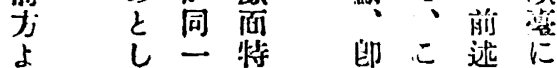

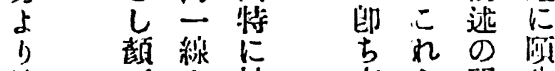

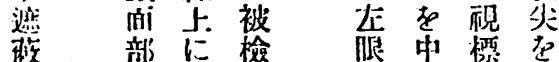

状, 郎來跟距忍板安

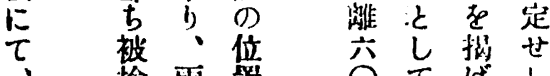

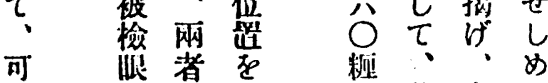

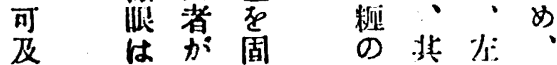

的圣定默 9 紧上

速常くし前距下

力口 简测微

に固に赑

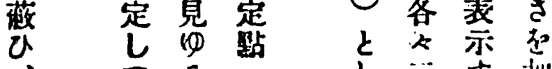

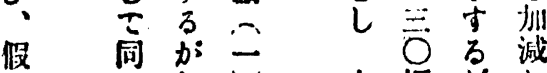

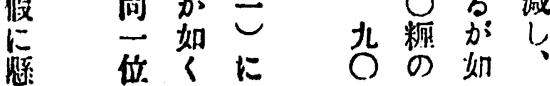




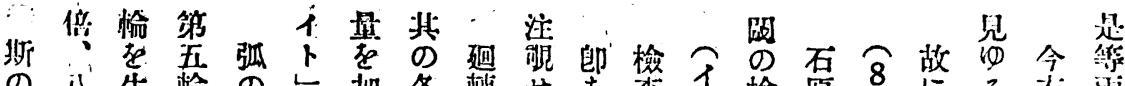

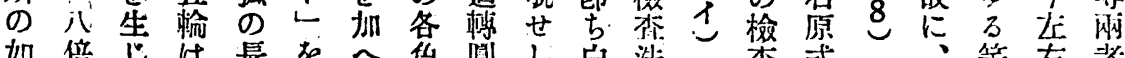

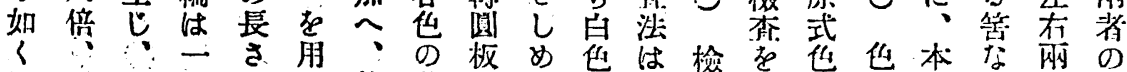

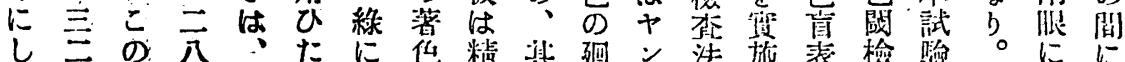

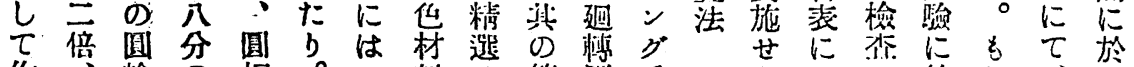

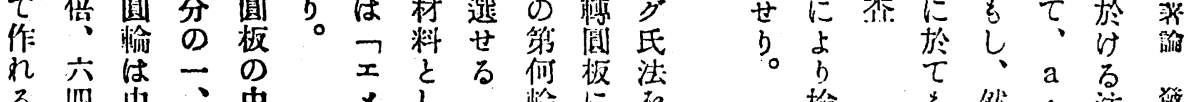
3 四中、中 $x$ 中榆に展

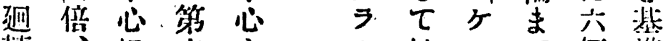

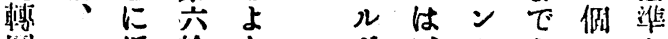

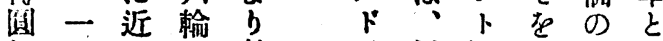

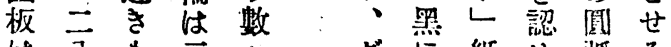
は分竞へ、グに紙め泒る

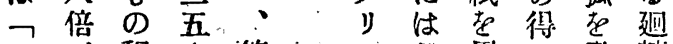

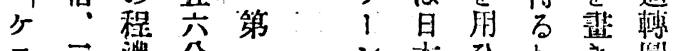

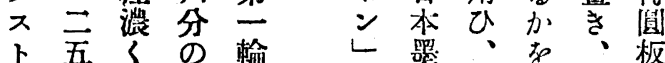
ᄂ六中一蛙青崄之法 紙倍心の圆に赤の栙老に

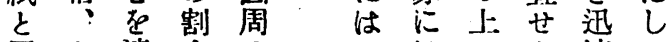

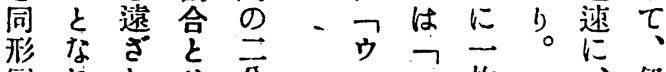
同れ加世分只兄枚僻

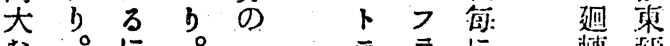

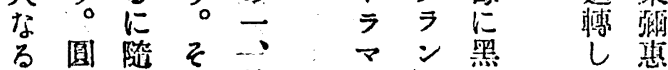
留板ひ和第少治 制 $\Phi \tau$ 故等㑊六氏 板直薄に輸 . ン錫・種の

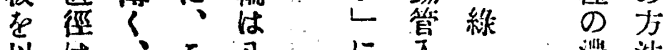

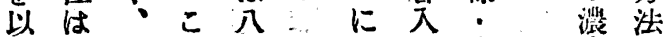

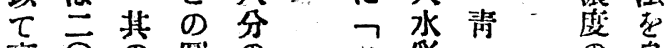

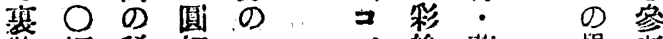

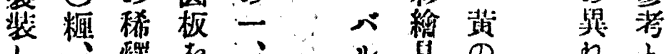

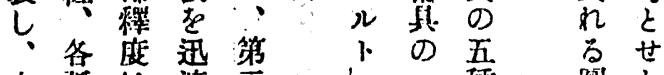

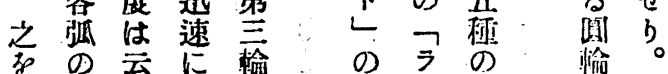

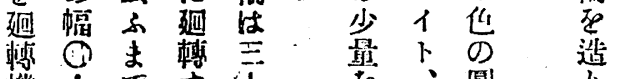

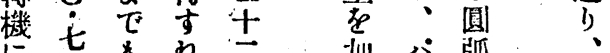

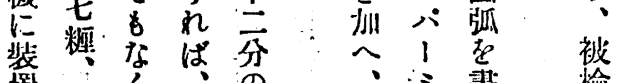

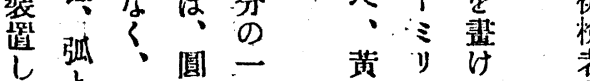

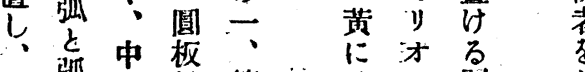

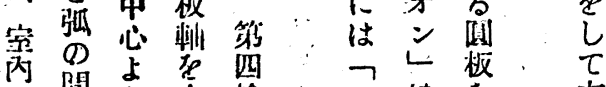

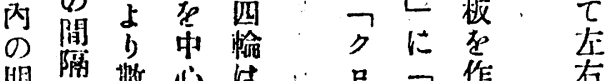

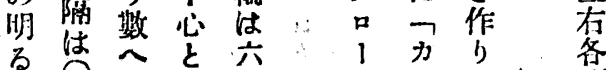

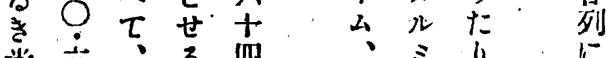

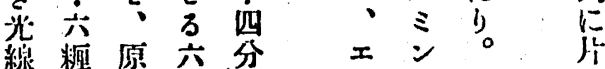

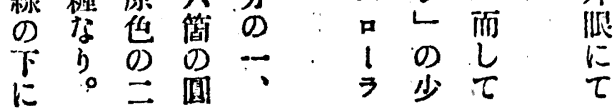

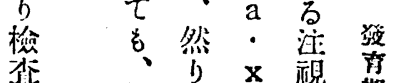

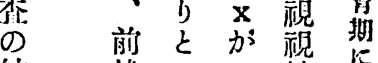
結逃せ 線、於

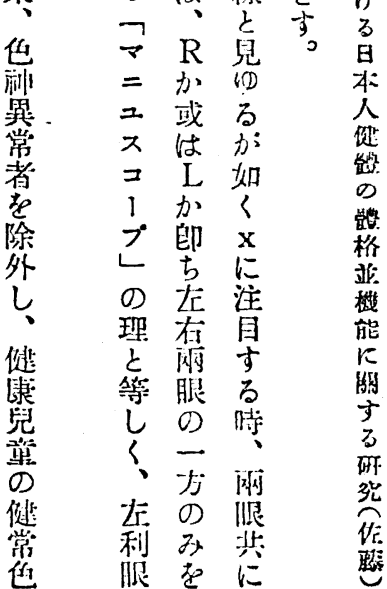

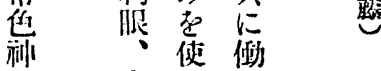
有用了 檢利世合 龺服るの せ 教

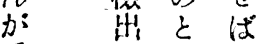
篇 吉 洘 尚光的

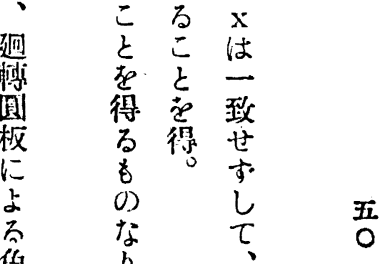
鼠占。 检 


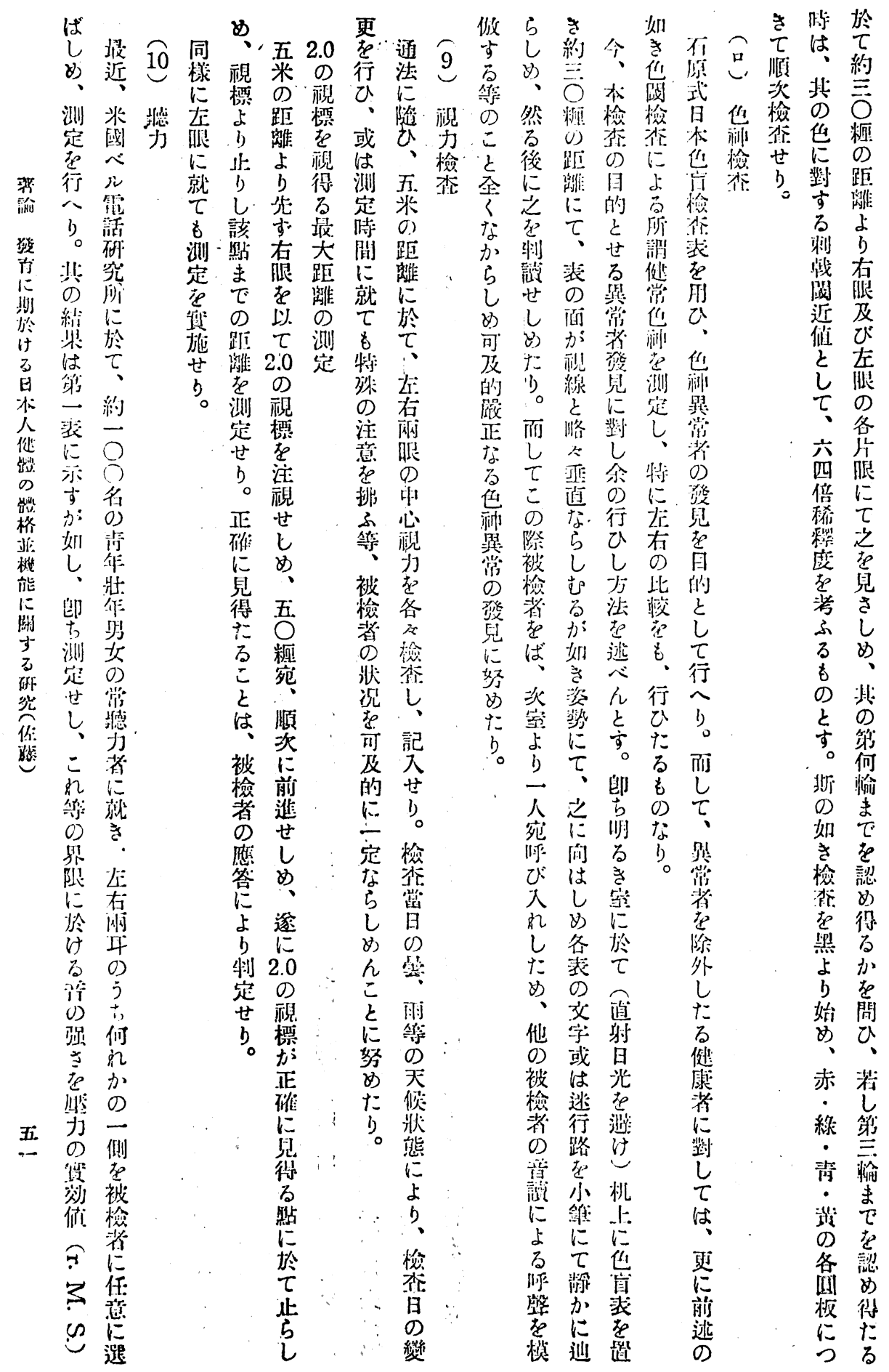


知 は

उ

第 一 定

\%. 红

猚澢

ए以

加

\begin{tabular}{|c|c|c|c|c|}
\hline \multirow{2}{*}{ 报畔蚁 } & \multicolumn{2}{|c|}{ 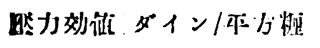 } & \multicolumn{2}{|c|}{ 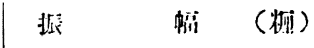 } \\
\hline & 酦小界阳 & 泥大界限 & 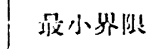 & 设火界限 \\
\hline 32 & 1.0 & - & $17000 \times 10^{-8}$ & $-\times 10^{-2}$ \\
\hline 64 & 0.15 & 200 & 1200. & 2.5 \\
\hline 128 & 0.03 & 900 & 120. & 4. \\
\hline 256 & 0.036 & 3000 & 12. & 6. \\
\hline 512 & 0002 & 6000 & 2. & 6. \\
\hline 1024 & 0.0009 & 4000 & 0.5 & 2. \\
\hline 5048 & 0.0006 & 1500 & 0.2 & 0.4 \\
\hline .096 & 0.0007 & - & 0.1 & - \\
\hline 8192 & 0.0015 &.$- \cdot$ & 0.1 & - \\
\hline 16384 & 0.1 & - & 3.2 & - \\
\hline
\end{tabular}

分剕

○しな

点

印吾

占 の

1 耳

几 感

炎度

一此澢

桼 附

の 近

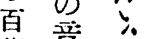

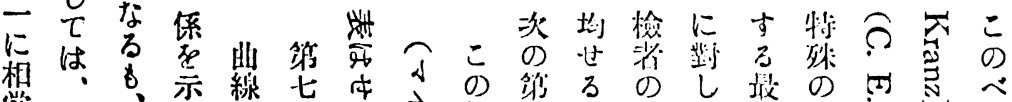

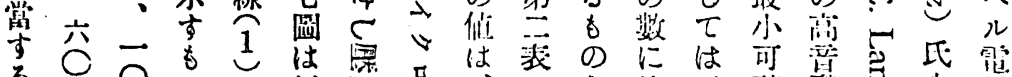

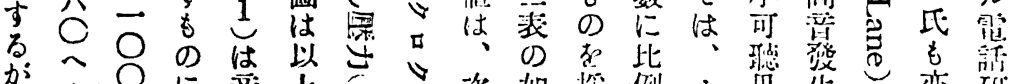

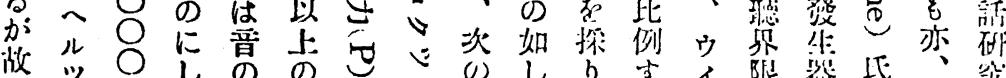

故”沙し

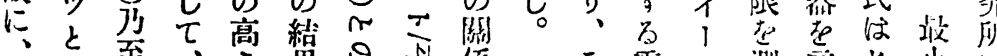

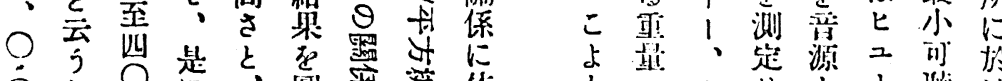

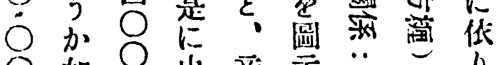

○如 $\bigcirc$ 年音示

一党

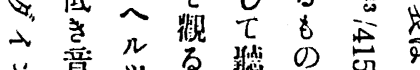

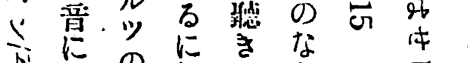

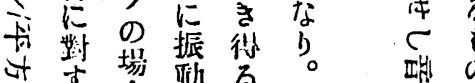

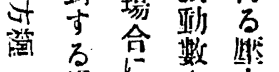

は場背努

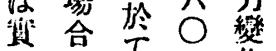

に合元花

二数 は $几$ の

第百○

些倍穴少

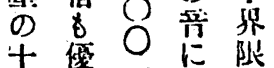

境 $九$ 在 $c$

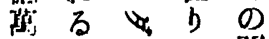

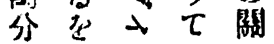

濑 O

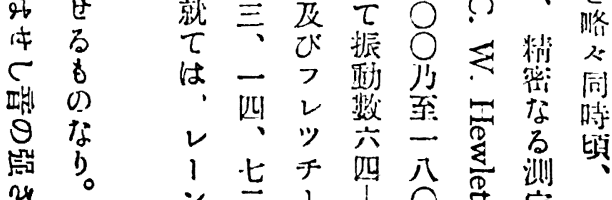

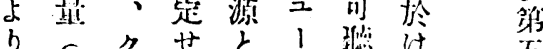

の $\tau$

昽留

の

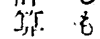

售口浑

b ᄂ 独

in 期

位於

は け

主

$\rightarrow \quad$ 水

신 就

$ت$
$ت$

管

通柾

站

1 k

¿

なる る

b) 结

站 仵

地

[114

改

第

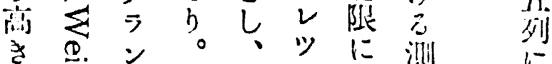

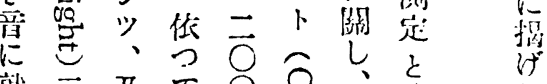

就三及元饮济

て一び振

当 氐

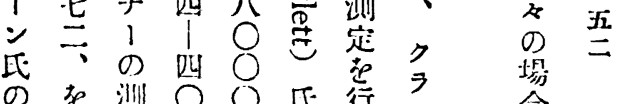

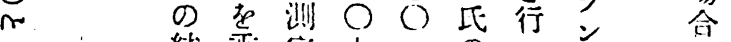

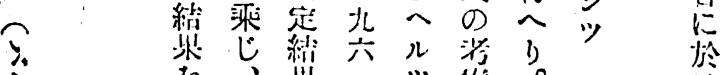

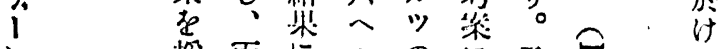

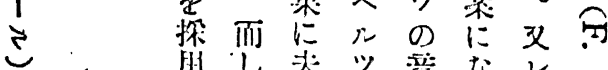

it

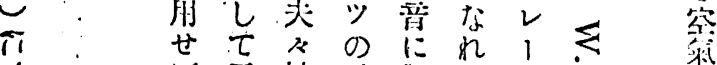

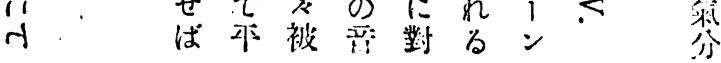




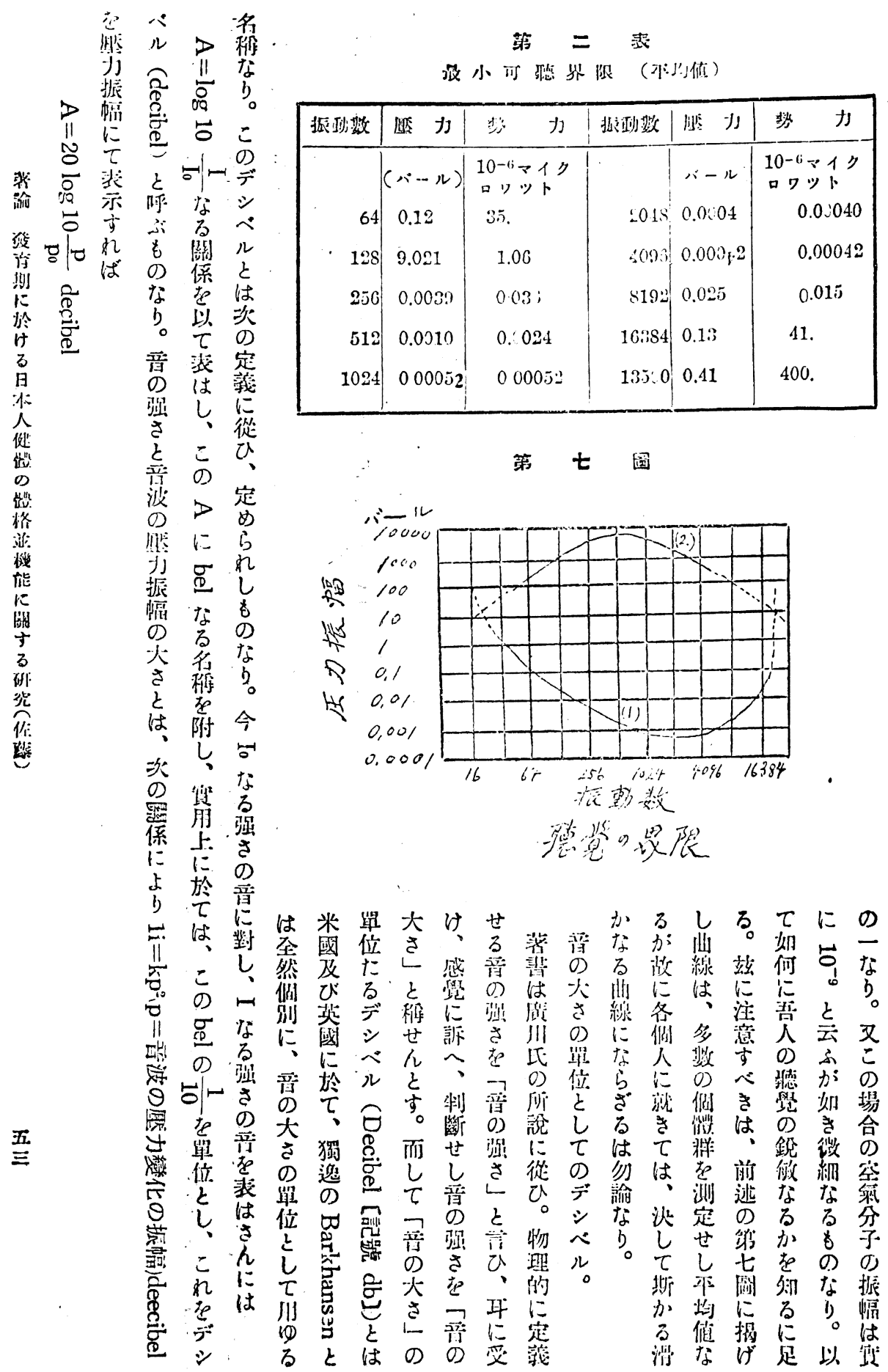




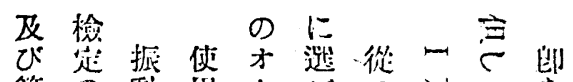

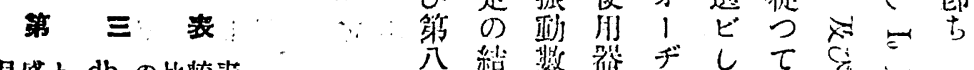

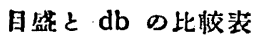

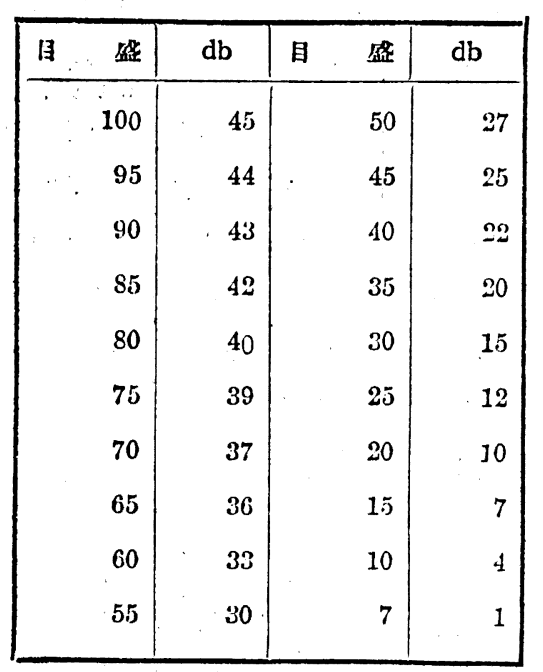

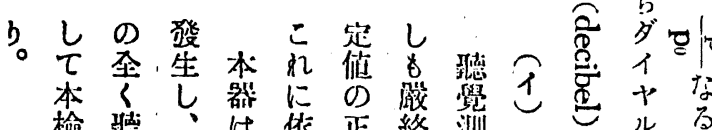

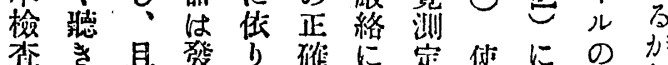

器得亏振七謟方前し一吙

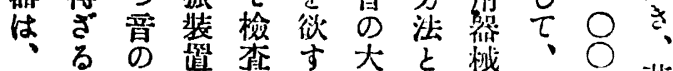

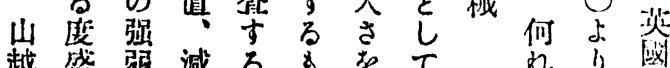

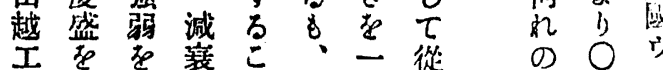

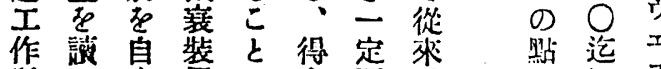

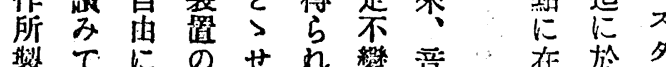

留てにの世れ變晋”在於夕

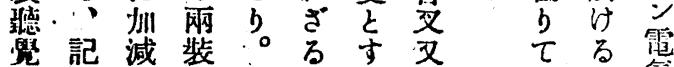

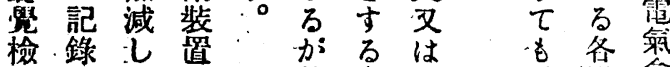

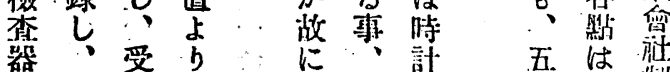

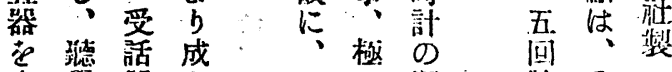

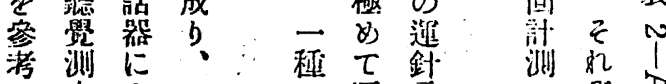

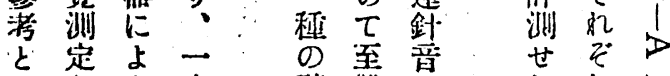

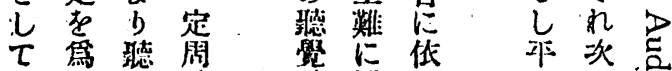

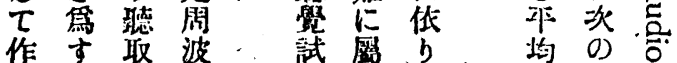

成合世思

せ

3

क 2 音

な而晋晏

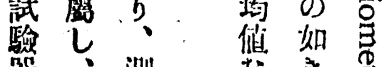

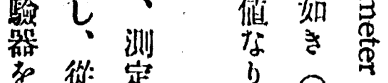

等 海: 定

㷛 $\tau$

b余然:
, 世

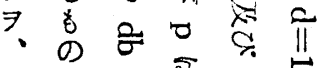

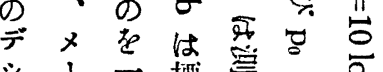

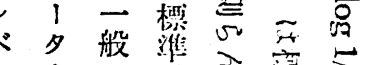

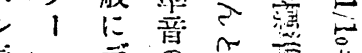

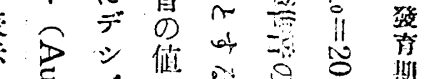

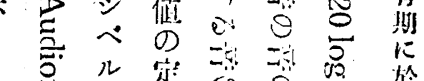

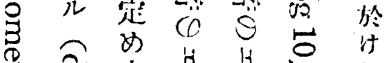

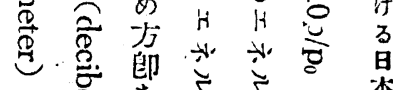

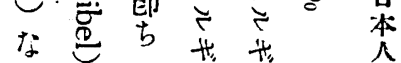

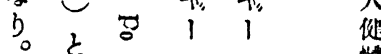

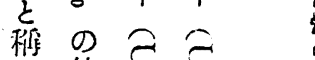

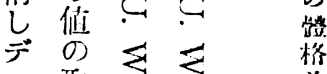
シ取岕脢 ヘ. 占

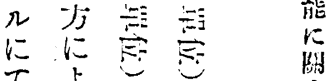
立过盟

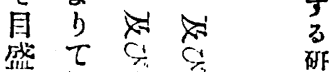

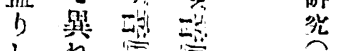

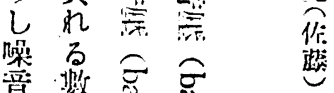

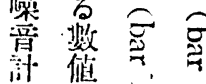

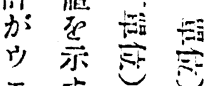
$x$ 古

ᄌ

\$ $の$

雷京

鼠今

會今

ऐ

量

值哲 酒

㝵.

嘬

超向

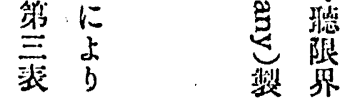


第八圆

128. Cycle

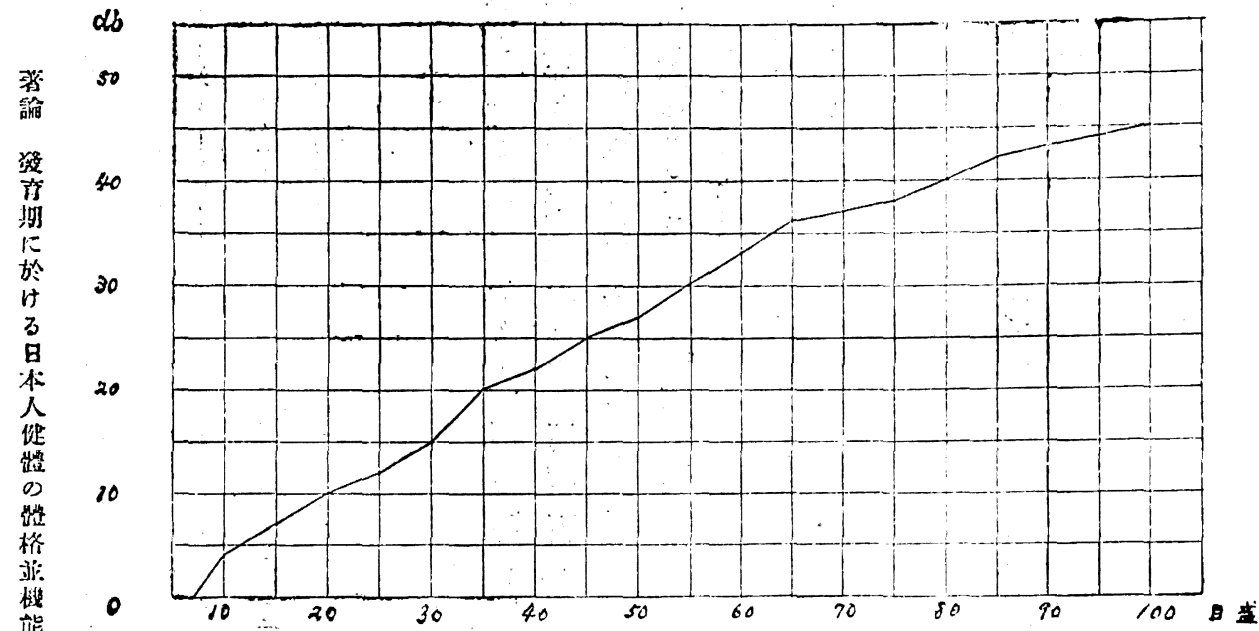

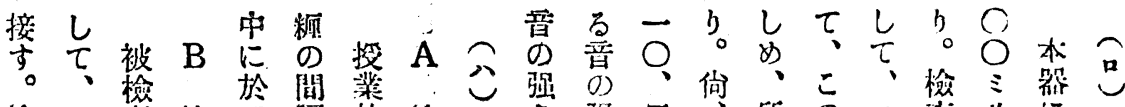

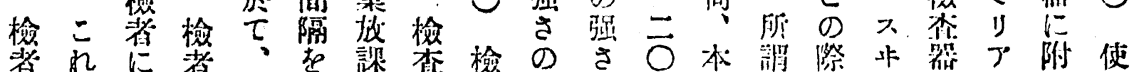

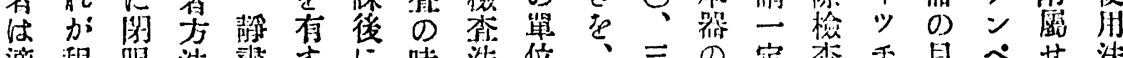

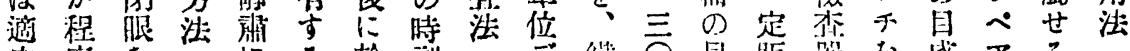

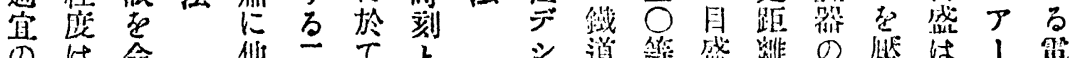

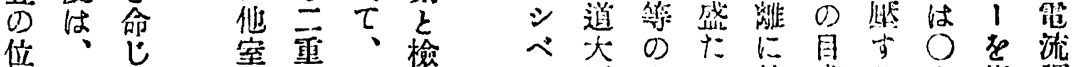

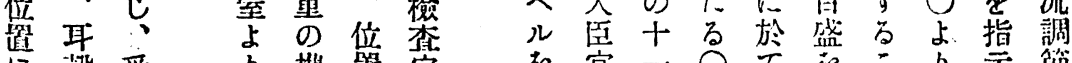

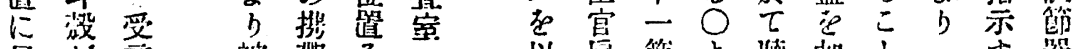

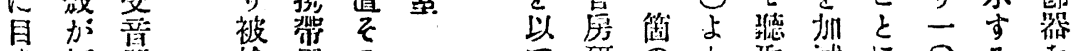

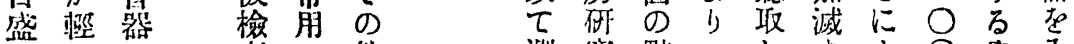

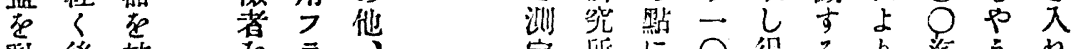

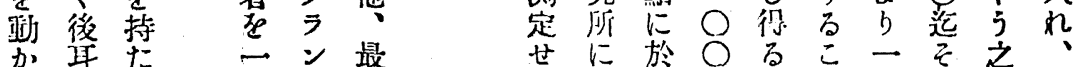

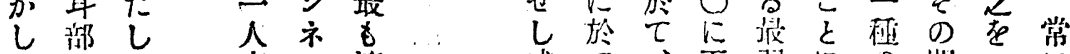

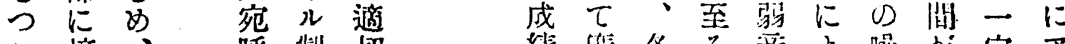

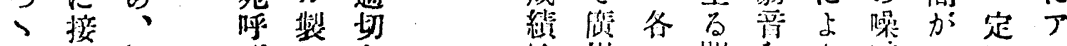

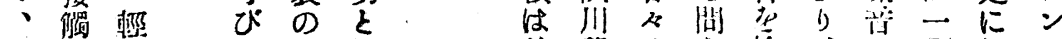

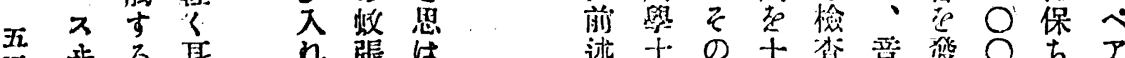

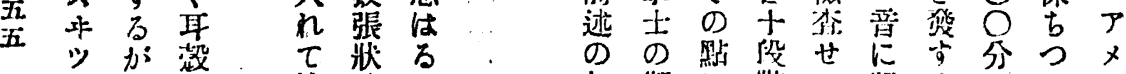
于 如に: 檢防

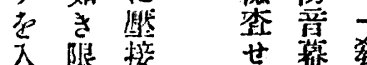

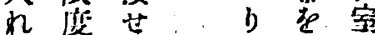

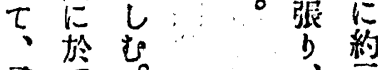

覃它而慕

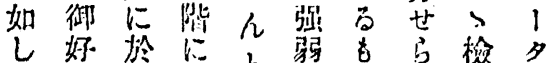

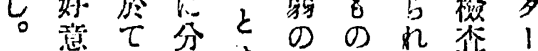

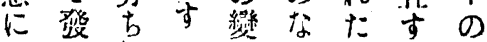

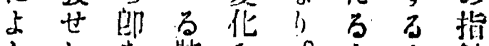

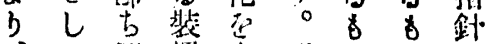

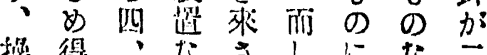




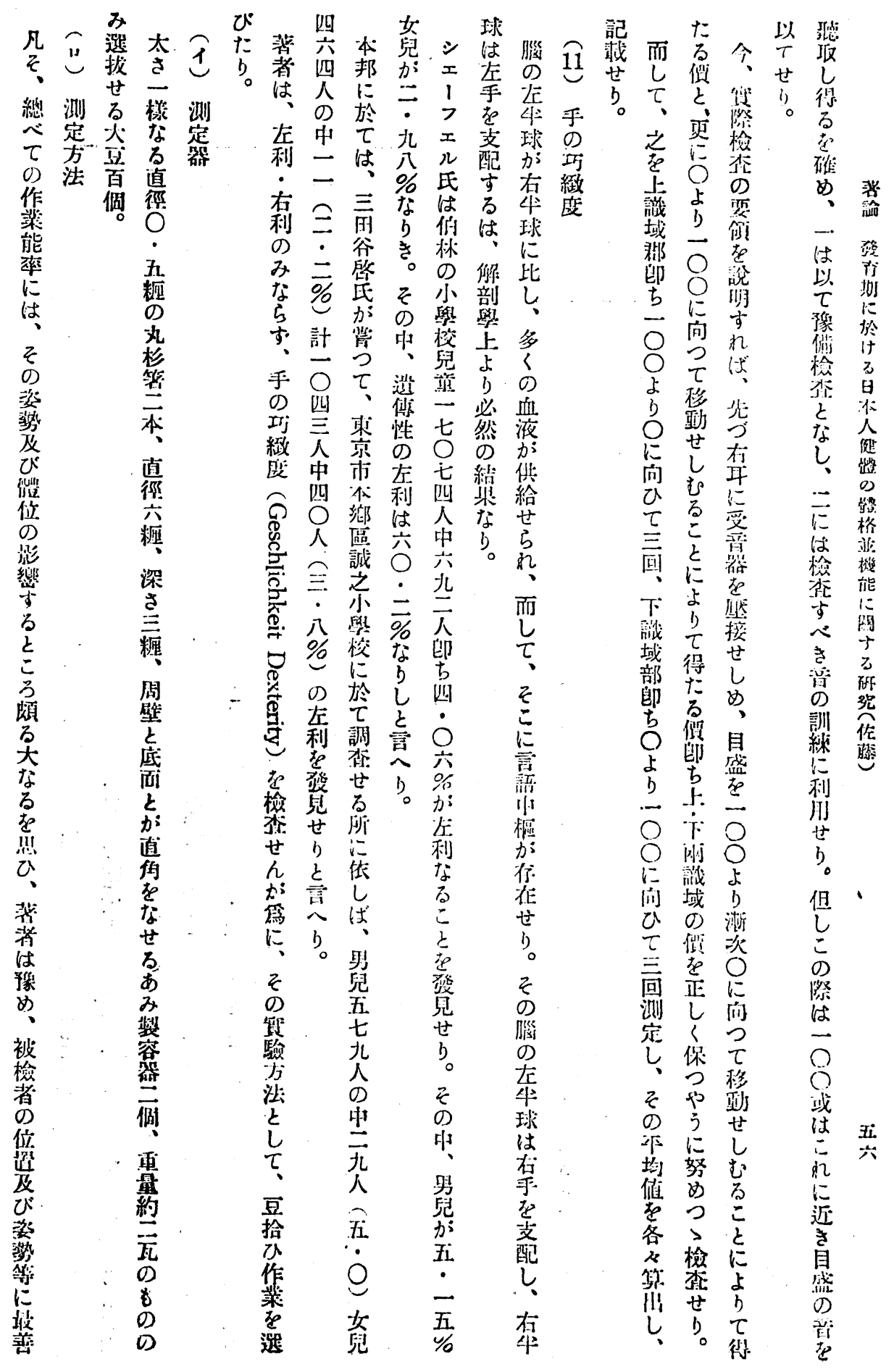




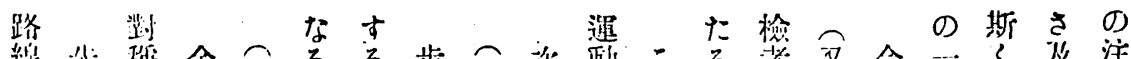

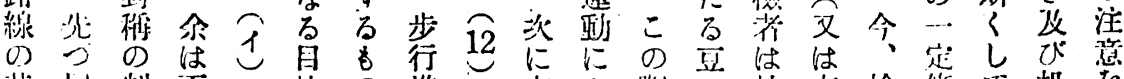

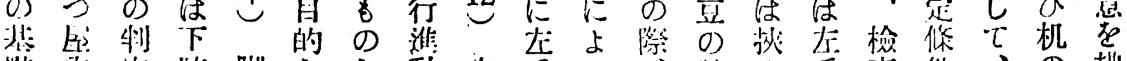

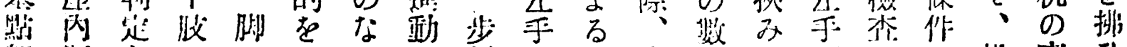

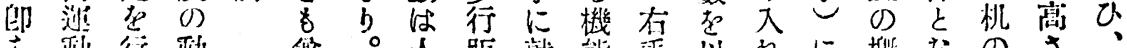

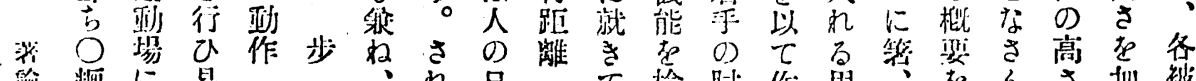

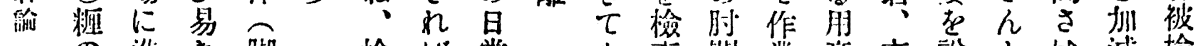

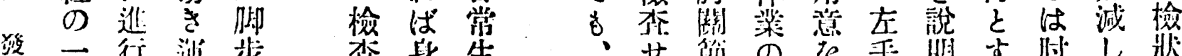

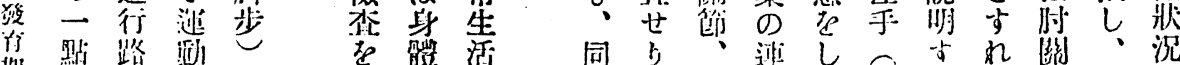

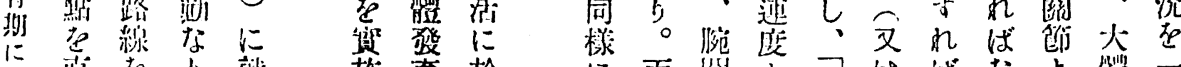

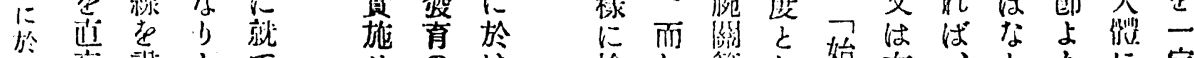

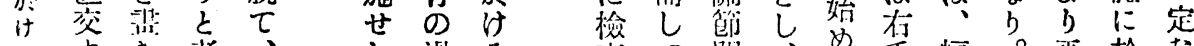
己占き浖、し過る

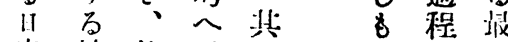

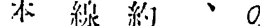

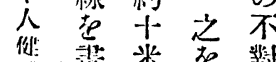

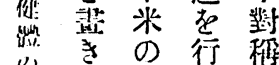

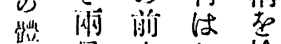

枌足方し 檢

格 博

機指高しん

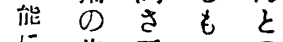

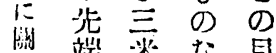

与端来な目

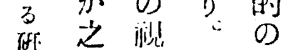

光占栖然焉

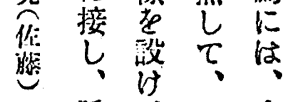
な於普 b宁通

こ 昷

加基

㗶 礁

稀的

をな

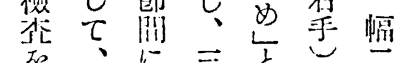

雊

察勤

小

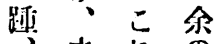

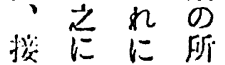

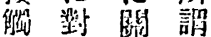

點 し $し$ 脚

方: $\tau$ 步

蕉自三檢

行然程 湘

路のの隹

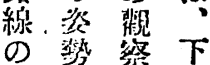

延に在㘷

居於行 の

線元狼

榀 。

龺

は

琶

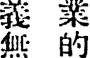

活

あ 舫

亦

吉步

信 に

上近 b 作

橴

五 一立。犃

前 逨

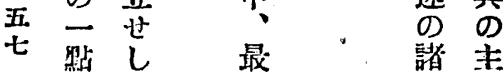

黙し最”諸圭

來战呰

項㢈

るこ純

䅉業

加证

け の

如際它

な蕉文

z $\vec{z}$

京唀

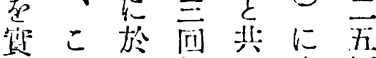

施の行行空糖

せ前るは可熄

平於な

約市记

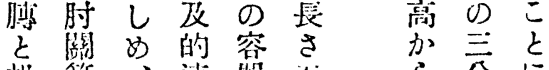

机解、速器

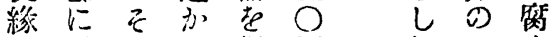

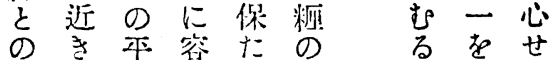

な肘岣器し机总养!

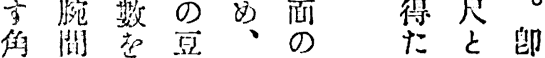

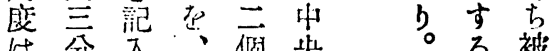

約等 せ他の杒检

七 $\bar{a}$ b 9 容 $b$ 的者

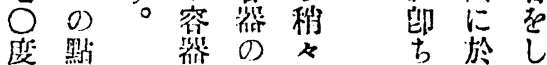

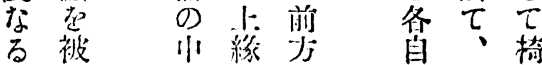

力: 检目苂に被坐

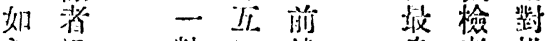

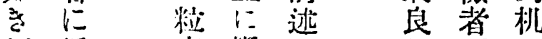

倾近苑的留の ながの

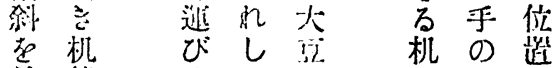

前綠 入め-上動に

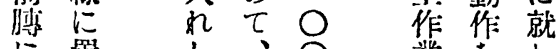

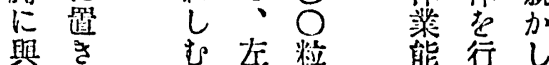

人、有蛋率ひめ

たこ然に久得た

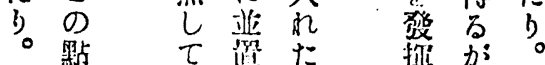

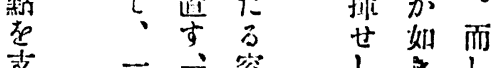

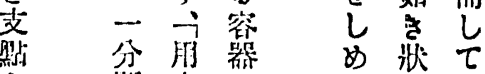

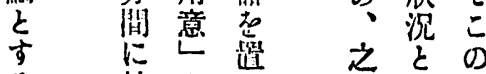

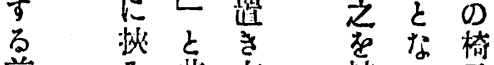

前脽共右被せ子

の被乎检り。高 


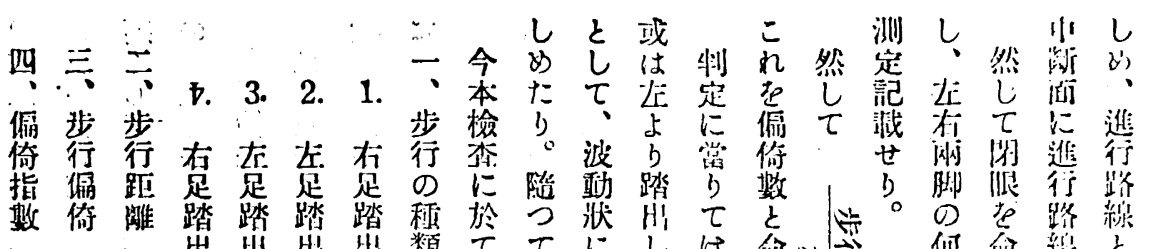

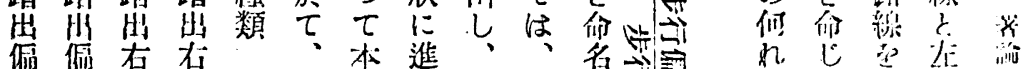

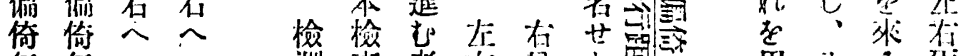

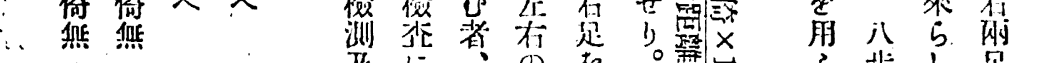

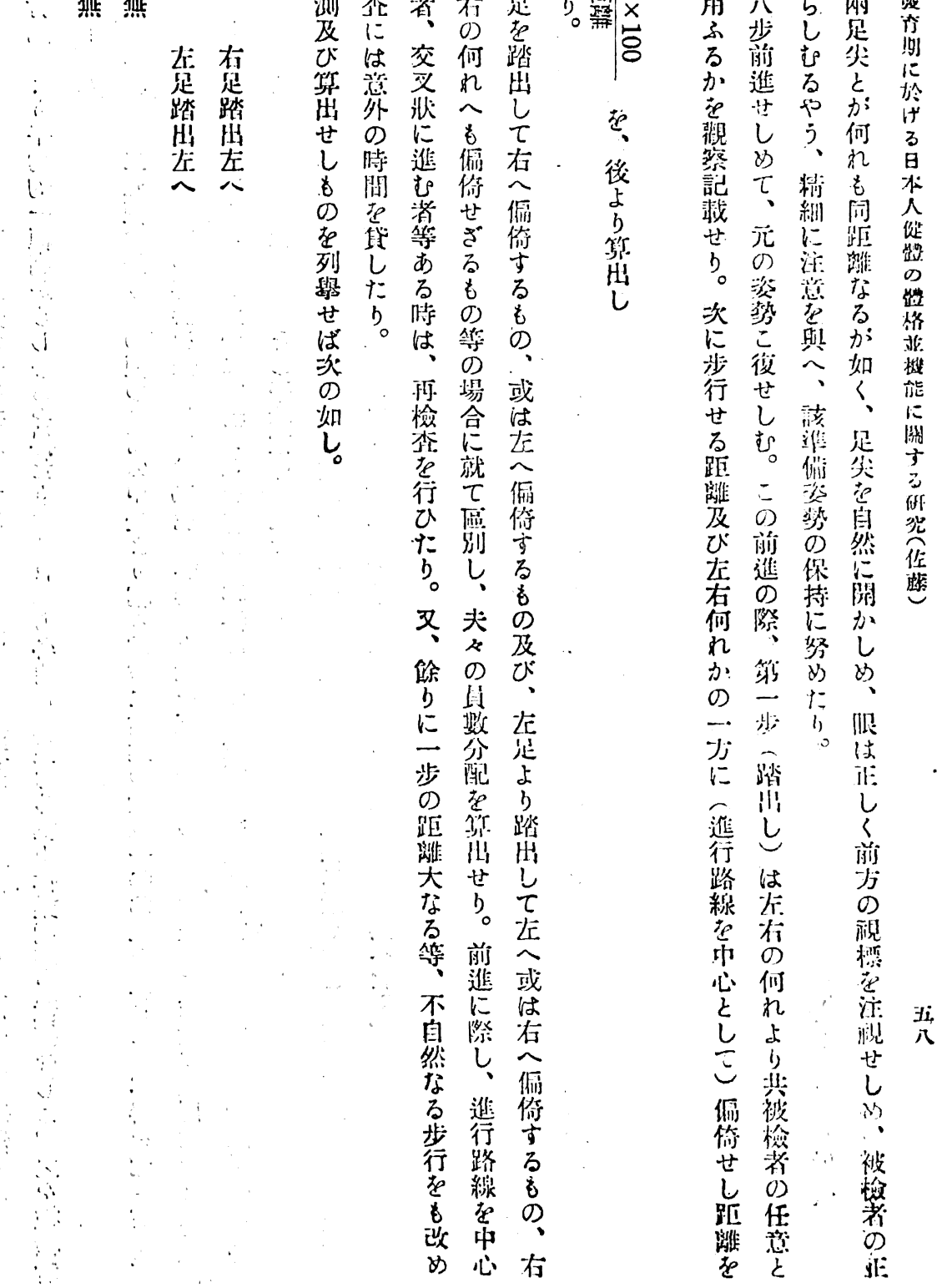




\section{169}

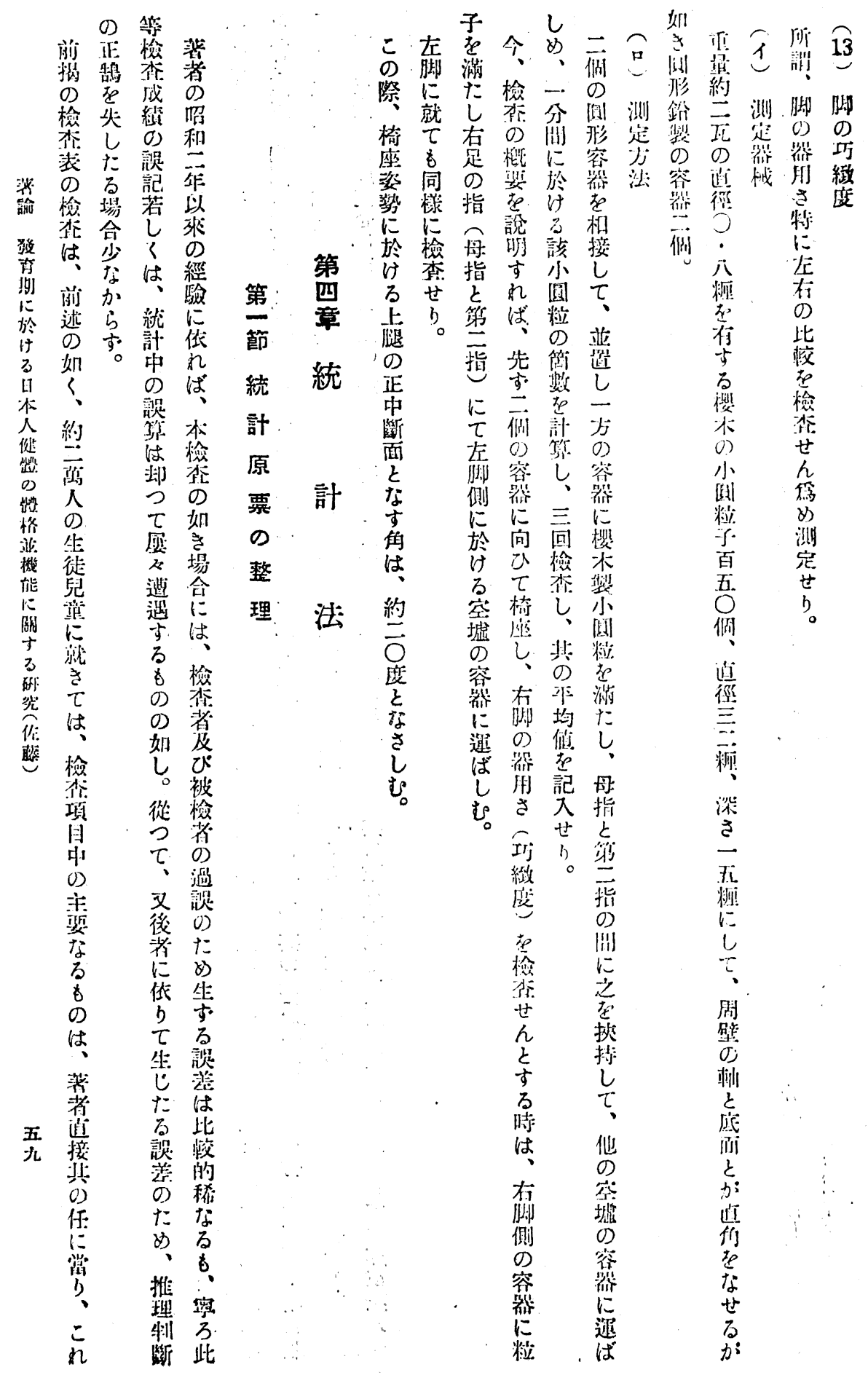




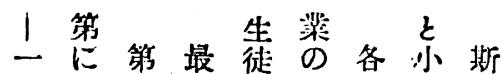

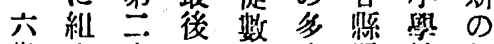

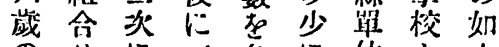
の世に!各に位

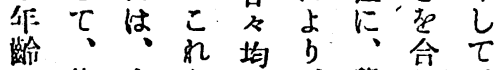

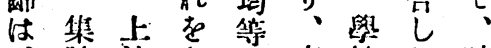

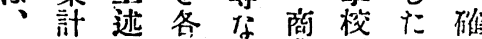

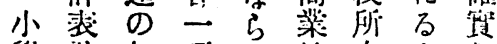

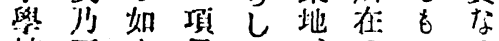

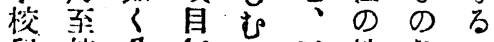
兒統全等: 号地な心

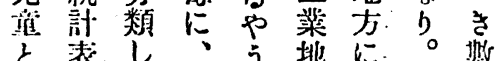

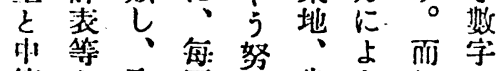
等声取回多生

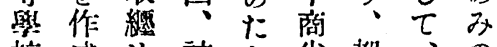
乑成め該 54 都、の 生せた项。荘范原記

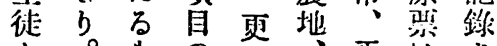

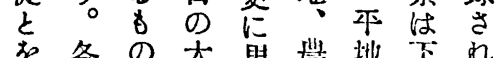

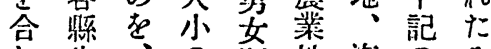

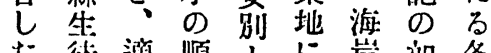
た徒鲖順々に岸漓各 万兒雷に罚地了和

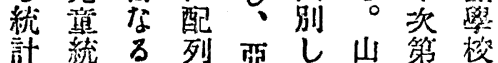

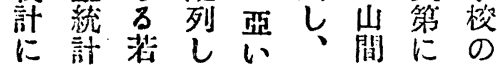
乙年にて而此分原 $\tau$ 於階b年しの類整

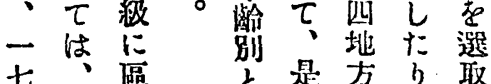

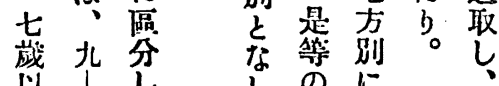

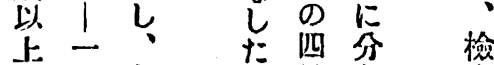

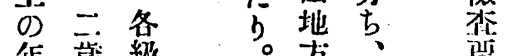
年藏 級 刜の の 纯人 中嵝 自 等 娄少筇 校藇 生校 徒 兒 の望分 維 の 配 計み表 If 0 b。統

。訫篗 等

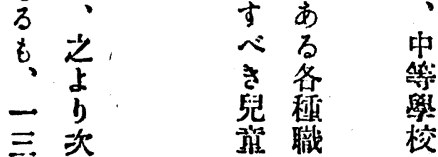

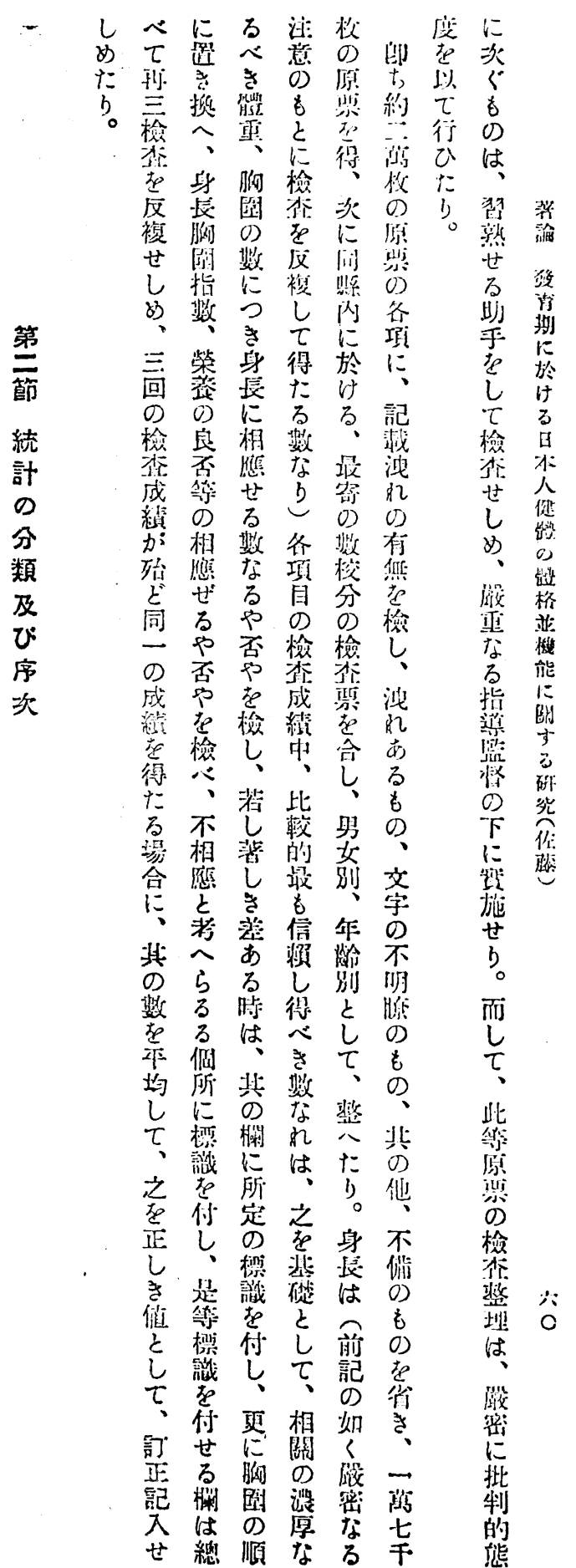




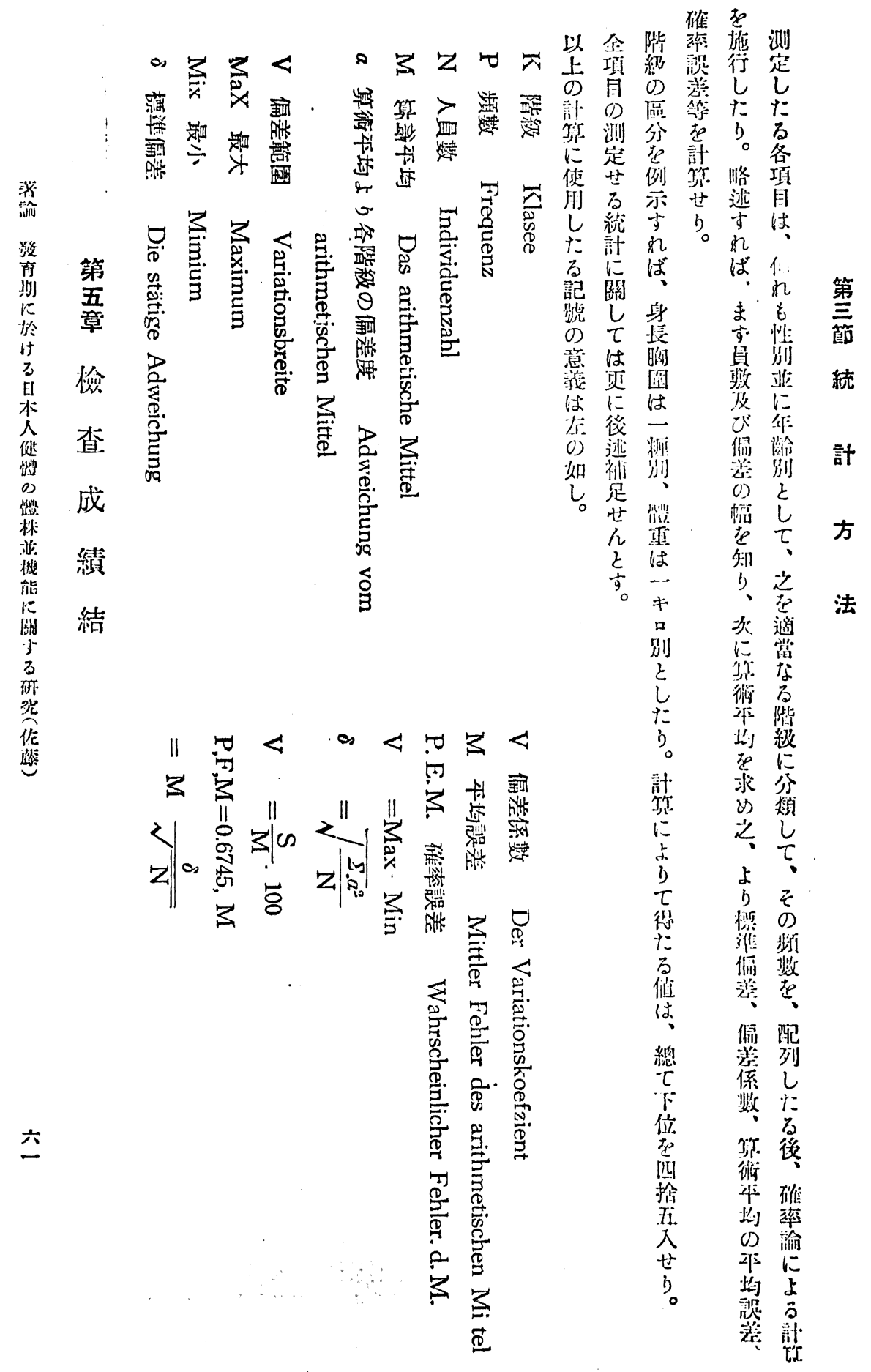




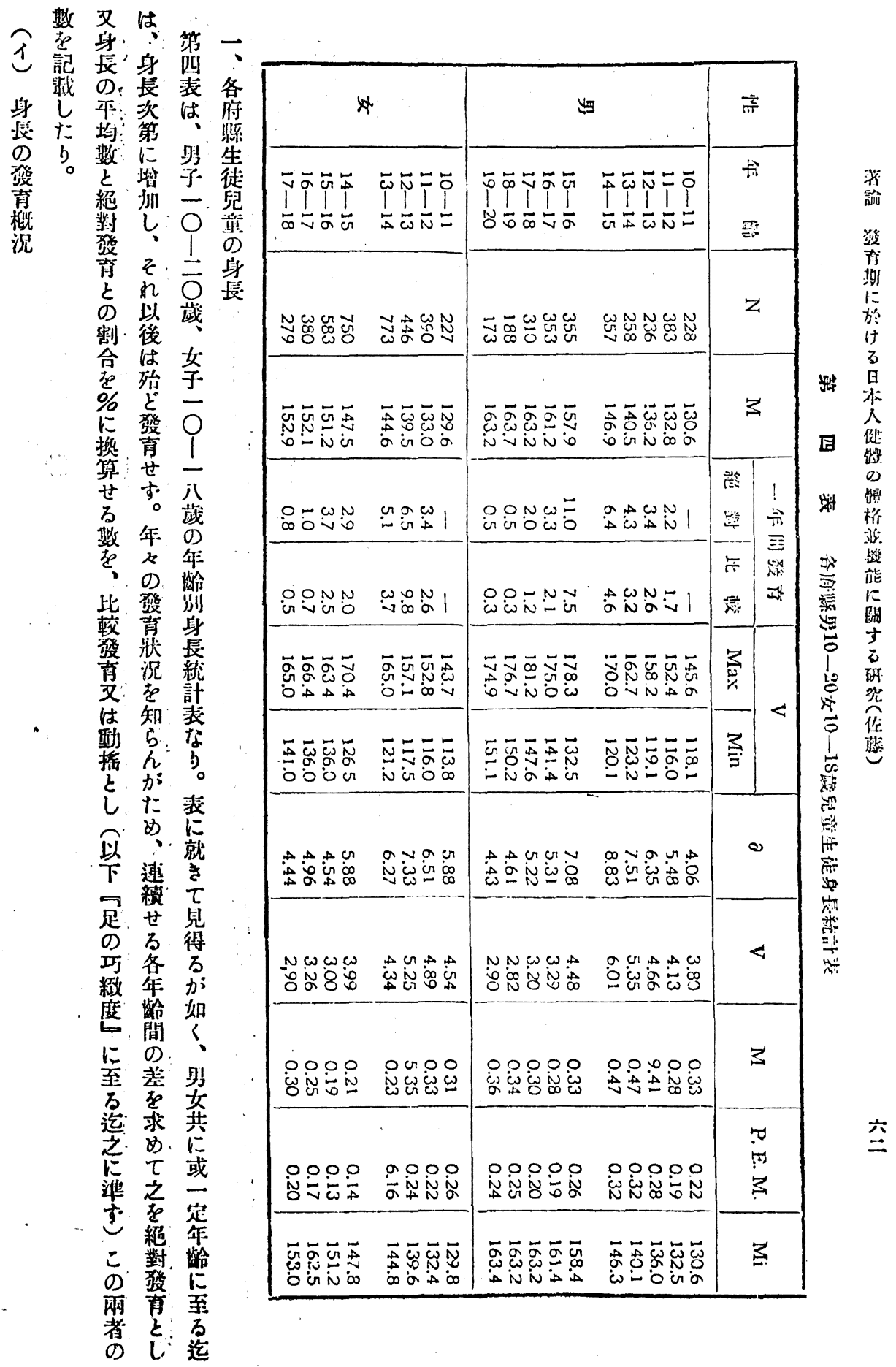




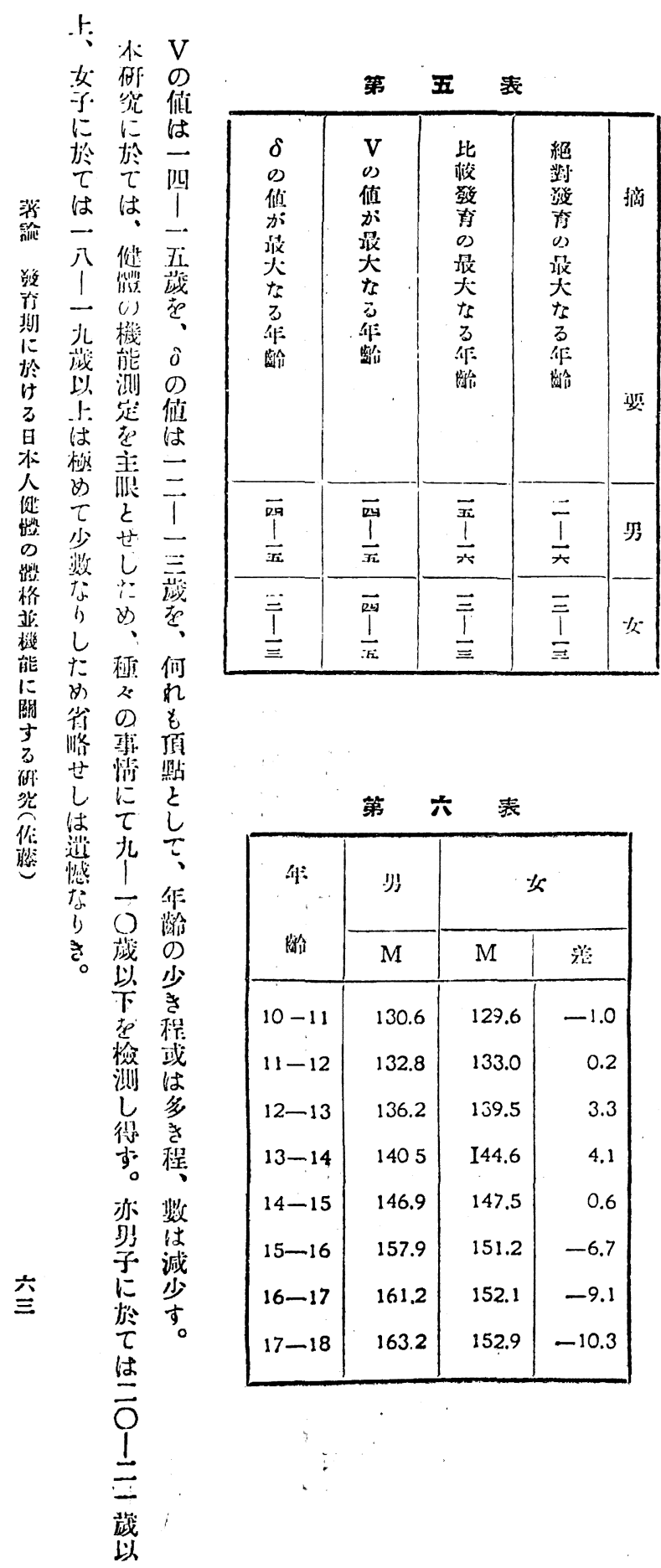

臂至

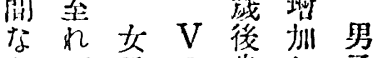
り 杖手の集し子

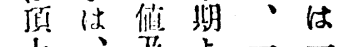

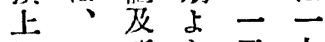

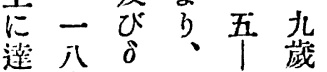

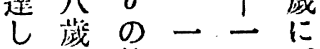
仁值六六至 以至蝛: 战 後尚、前の迄 は迄期侎、期

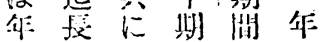

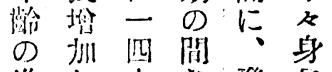

非し、1 登長

异以五。管

二後战媔热

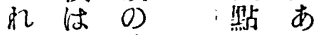

场㱠洔!にる

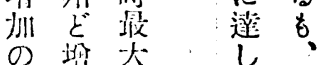

の留大 !

畣せ等

減立市六以

少。作藏後

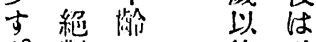

10 對 0 後 殆

而潑少壮と

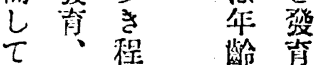

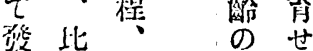

等整又非す。

蓝多热。

留筫得六

きに数 旅

作胙は场迄

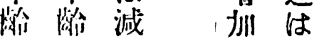

はの少のの

二非し、制絶

一 过 合 龁

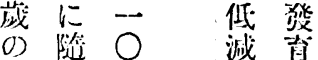

後包战減青

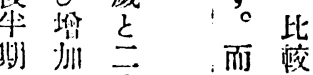

b

$\overrightarrow{0}=\frac{2}{2}$ 發基

茂门治 0 年

の -

前三類 し

性藏似进

斩の

至䊼。從

るに 三從 


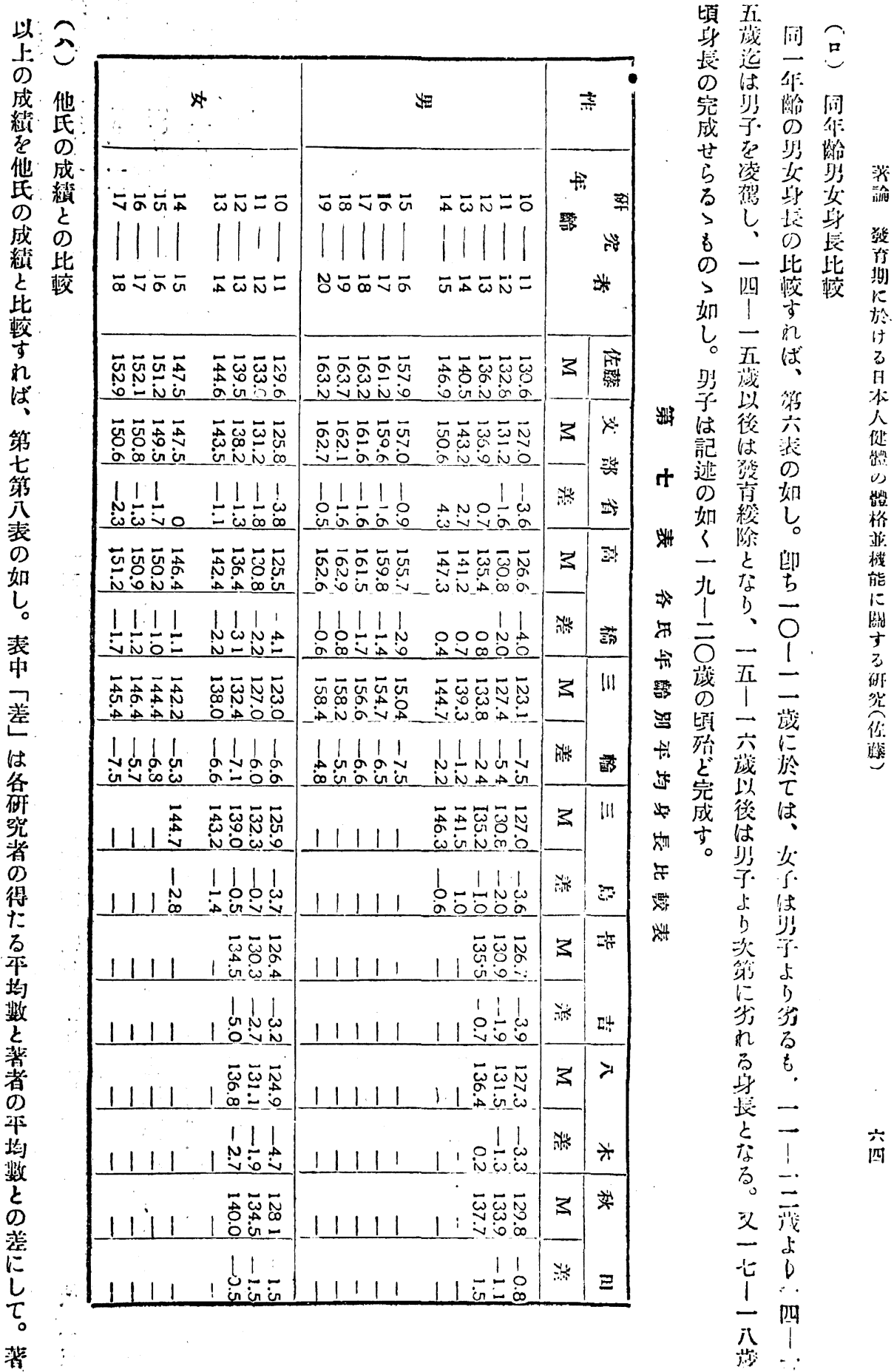




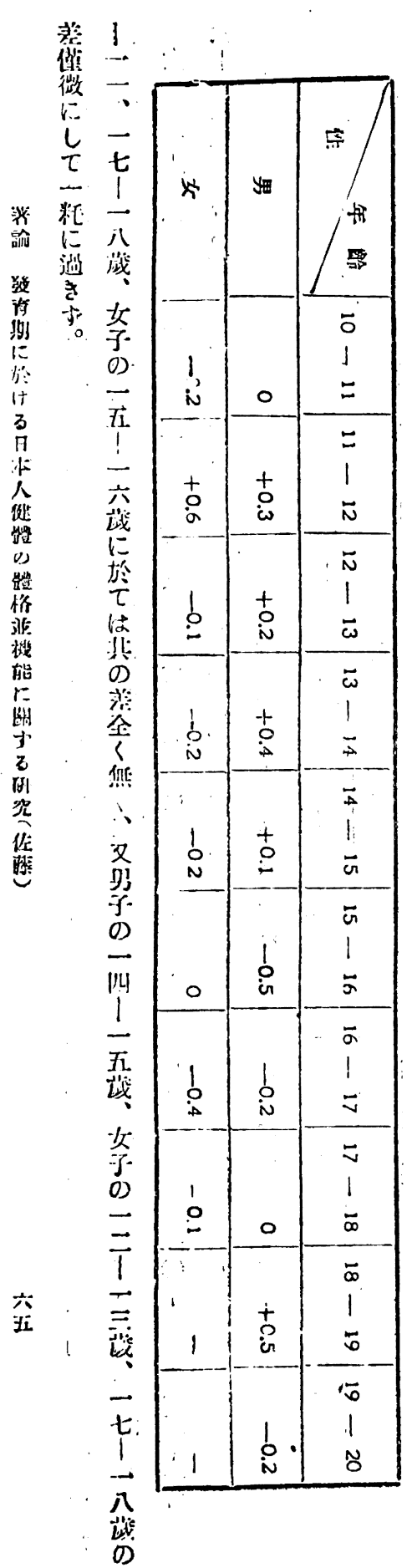

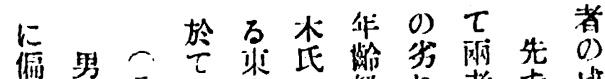

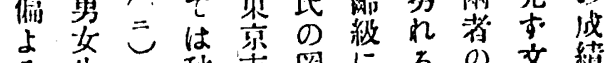

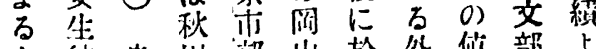

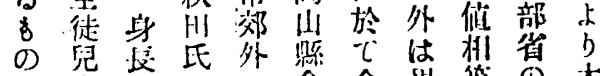

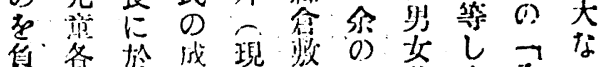

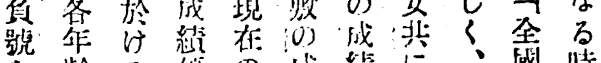

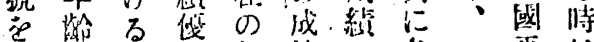

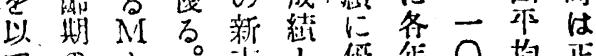

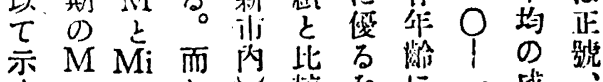

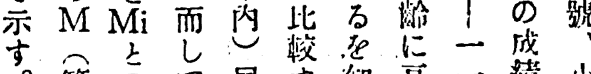

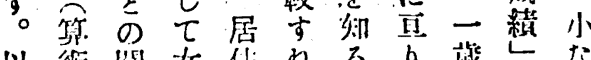

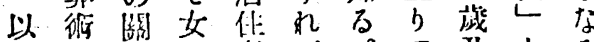

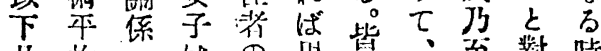

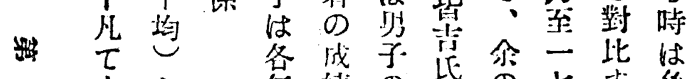

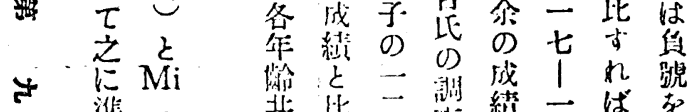

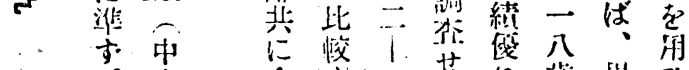

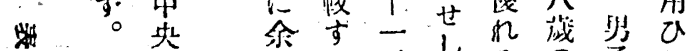

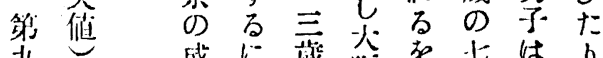

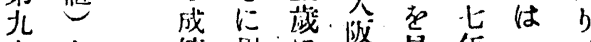

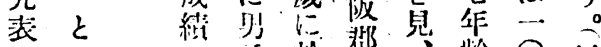

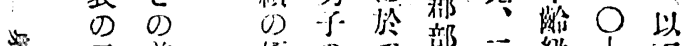

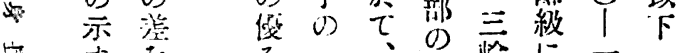

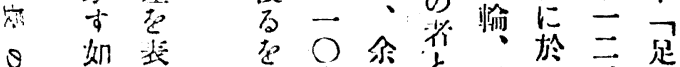

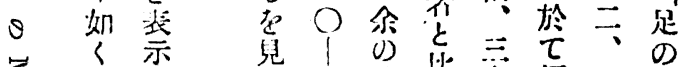

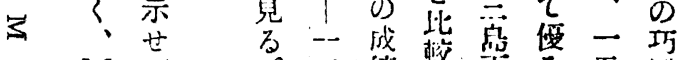

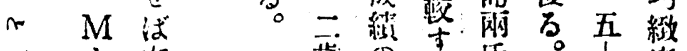

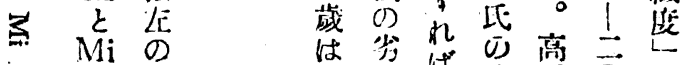

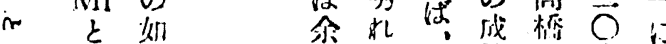

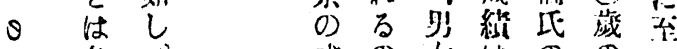
冬。成の. 炎はのの石

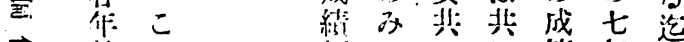

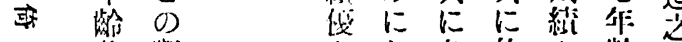

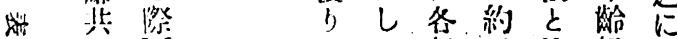

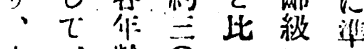

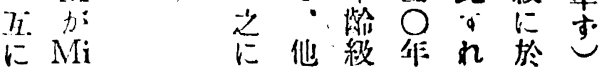

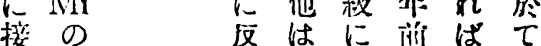
近有则於の娅

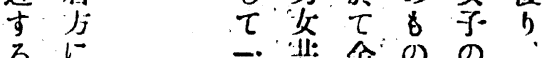

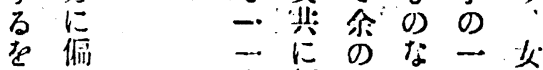
胃占 1 烈成了三尒

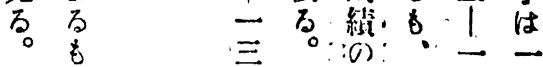

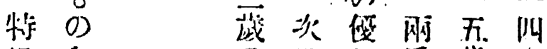

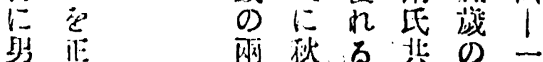

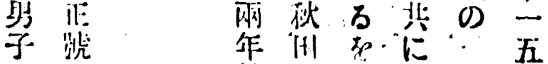

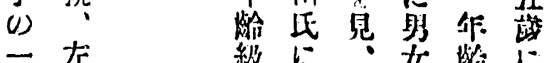
$\overline{\mathrm{C}}$ 辑

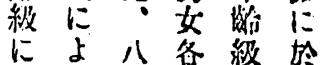


照

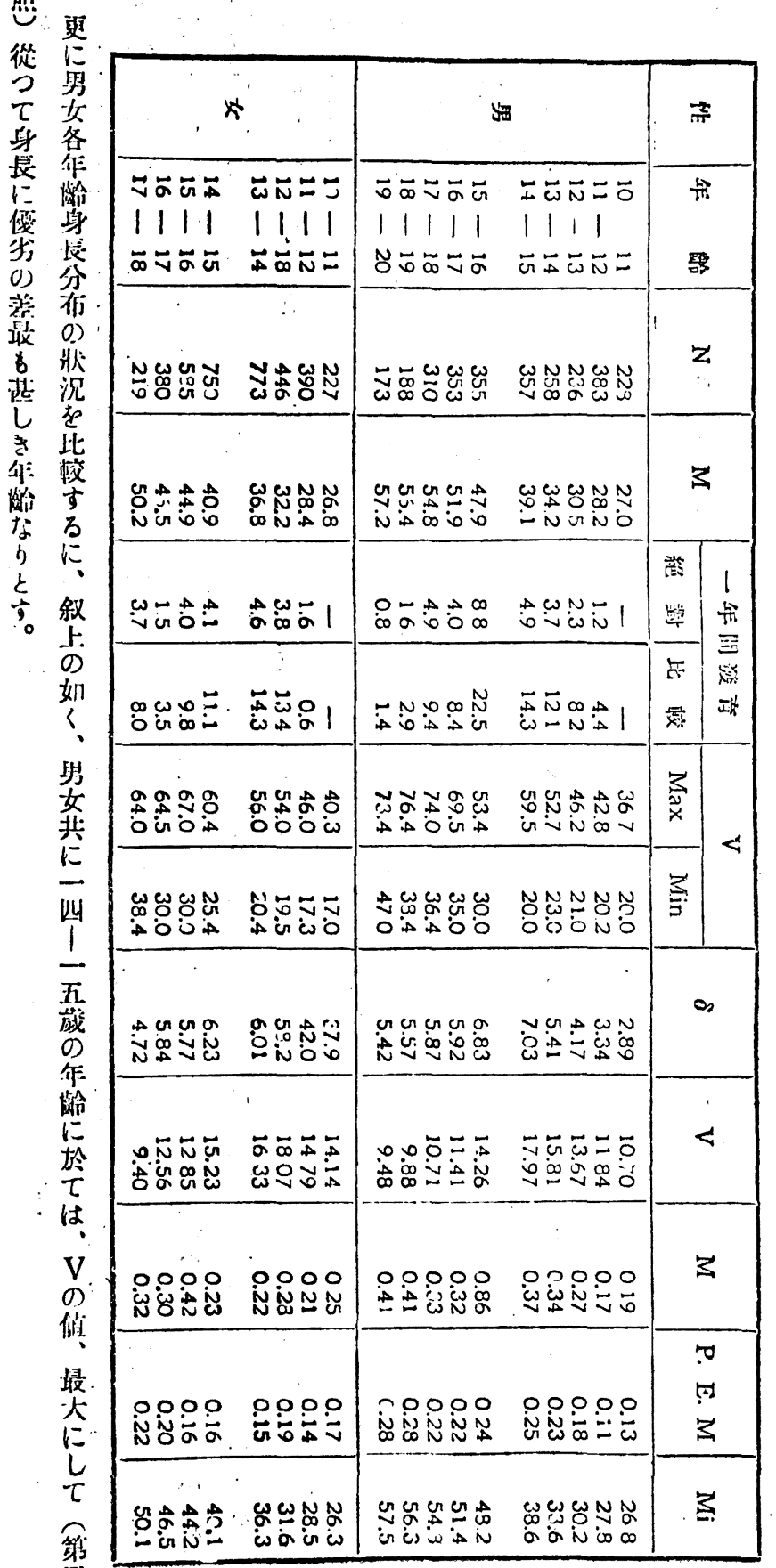

六且

1怒驾

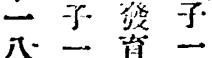

画 $\rightarrow$ 尼

に1遂 1

至愿五

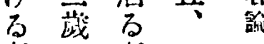

监の淡一

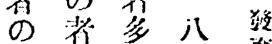

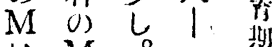

\& $M-\rightarrow$

$\mathrm{Mi}$ は 一 儿

O $\mathrm{Mi}$ 形鿊 it

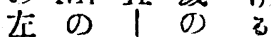

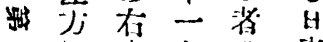

证七标

+ 俑に、 $\mathrm{M}$ 人

+上倫一は优

政

る \& 九 i

印, I

古從前在格

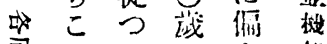

굴 $\tau$ 亡 能

悲 俳こ於 る

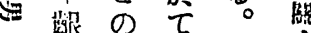

万作は從す

1 於陷 M

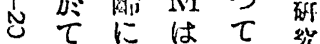

站於 $\mathrm{Mi}$ 佥

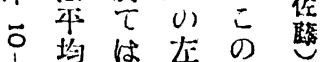

1均は应 の

d枃に跲

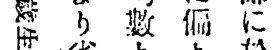

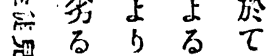

者榎。は

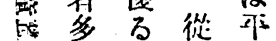

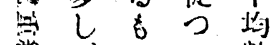

a $0 \tau$ 整

多 犃 よ

ᄂ 均 品

又占る

○少の

1 宁紫

- $\infty$ 肑

- 比多

一较

$\overrightarrow{0}$ 的

门多提

五语焉

$\rightarrow$ ば 


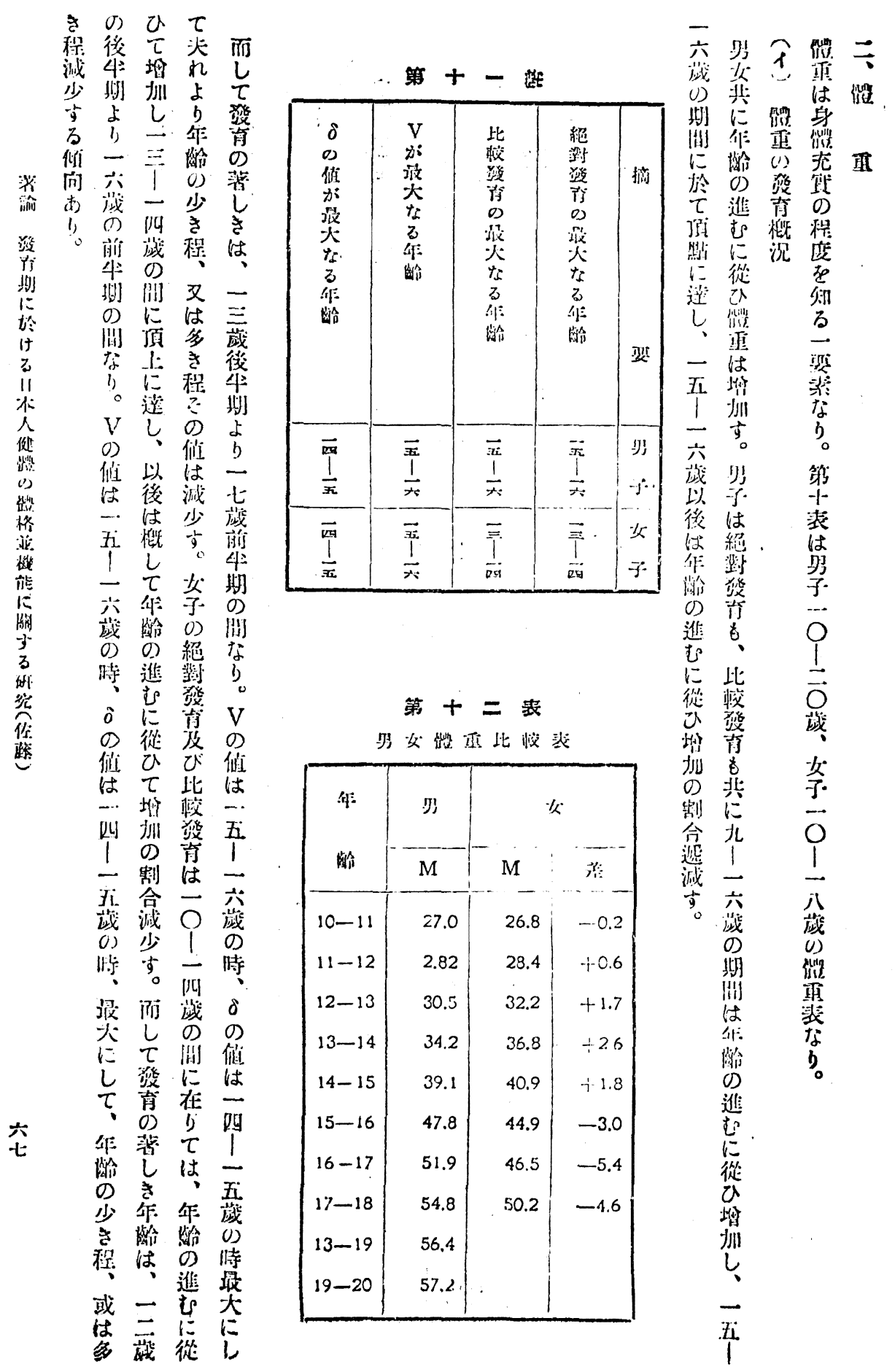




\begin{tabular}{|c|c|c|c|c|}
\hline 4 & $\checkmark$ & \multirow{2}{*}{\multicolumn{3}{|c|}{ 章 }} \\
\hline 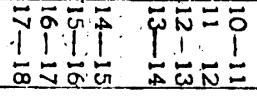 & 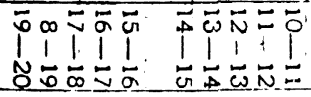 & & & \\
\hline 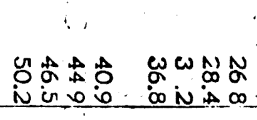 & 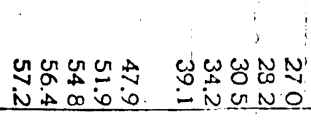 & 3 & 窝 & \\
\hline 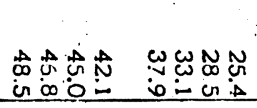 & 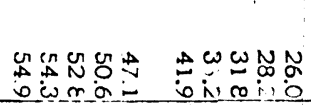 & 名 & 站 & \\
\hline $\begin{array}{l}1++t+ \pm+1 \\
-00=0 \\
=0\end{array}$ & 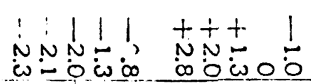 & 絖 & 形 & \\
\hline 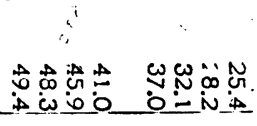 & 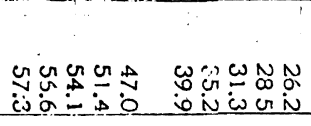 & 3 & 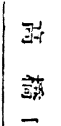 & 男 \\
\hline $\begin{array}{l}1 \div 1+ \\
0 \div 1 \\
000 \\
0\end{array}$ & 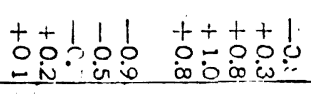 & 触 & 离 & \\
\hline 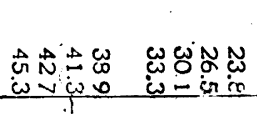 & 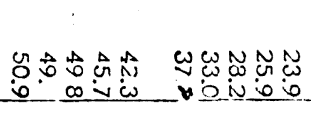 & 3 & iii & \\
\hline 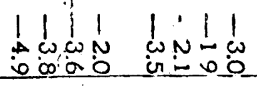 & 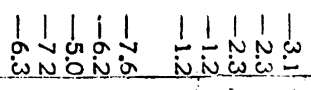 & 欮 & 䠌 & \\
\hline $111 \stackrel{\infty}{N} \omega_{i=\infty}^{N} \omega_{\infty}^{N}$ & 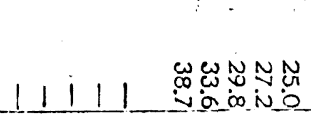 & 主 & III & ث: \\
\hline 111101110 & 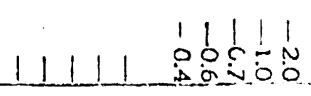 & sto & 焉 & \\
\hline $1|1| 1$ Wकin & $|1|||||_{\infty}^{\infty} \underset{N}{\infty} \underset{N}{N}$ & 고 & 踪 & \\
\hline 1111 N & 1111110000 & : & 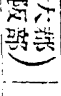 & 读 \\
\hline 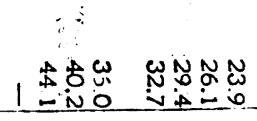 & 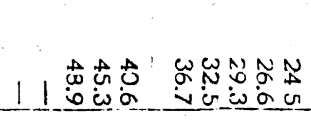 & 3 & 突 & \\
\hline 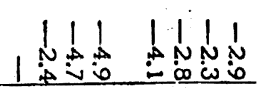 & 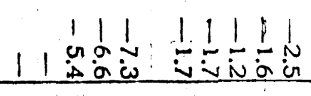 & 滥 & 商 & \\
\hline $11111 \stackrel{N}{N}$ & $11111 \mid 1 \underbrace{N}_{\tilde{N} \omega} \alpha$ & 3 & 美 & \\
\hline 1111 10: & $\begin{array}{r}+t+1 \\
11000 \\
\end{array}$ & 沙 & 空穿 & \\
\hline
\end{tabular}

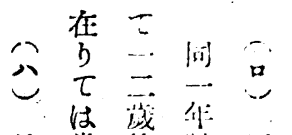

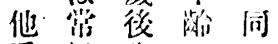

E

の. 贸 断男 年

成字占炎

緭 上 i。男

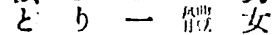

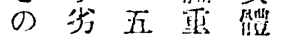

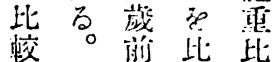

著

發

而罪此此

ᄂ 些

2

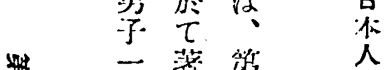

蛅 一著第人

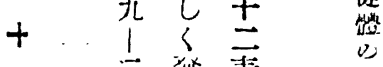

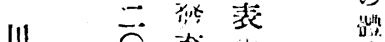

媾

䜤

7

궁

野

$\Rightarrow$

O 诵U U 桥

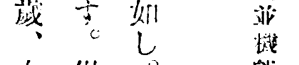

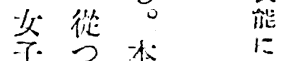

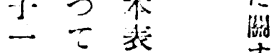

七二笈与

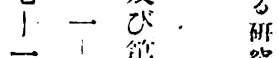

八 $\therefore .1 \%$

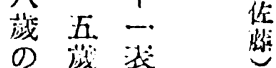

州

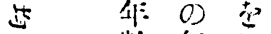

敬 尔秒

に敞合

$\Rightarrow$ 於的方

年正架

䙵 㟔て

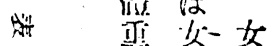

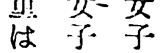

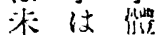

た旦画

發于.

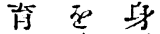

の 淩

途得

中 5 设

泟大

क है 础

万、势

拱期

の の 5

の他り

如 㤰貿

涼 


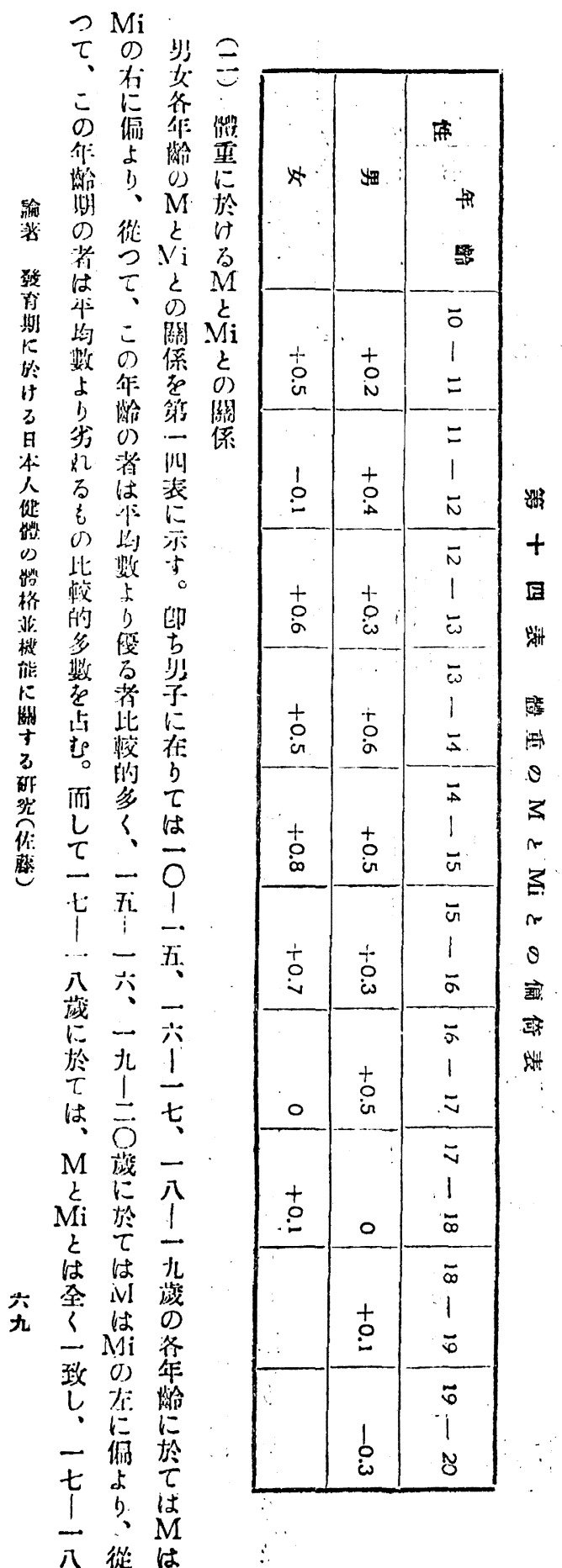

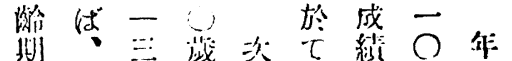

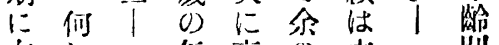

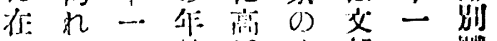

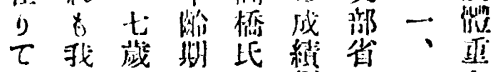

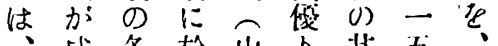

战各於而名其五。

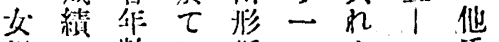

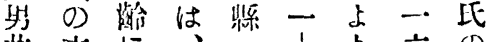

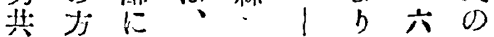

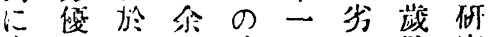

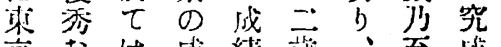

京なは成維藏、至成

郊占山程等

外。形上此至一兀皇

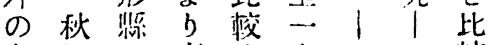

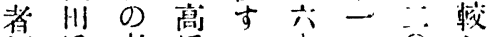

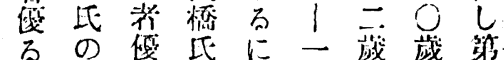

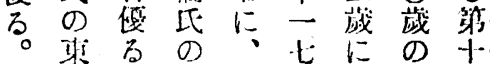

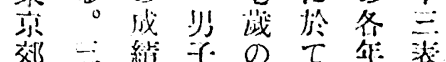

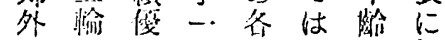

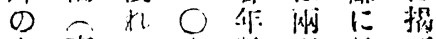

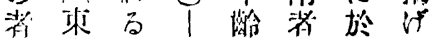
に等一に长てた

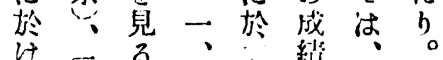
诘㤩。我縞我先

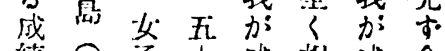

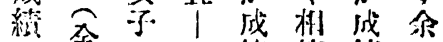

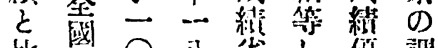

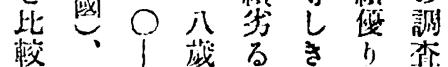

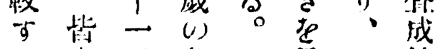

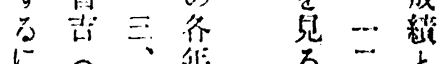

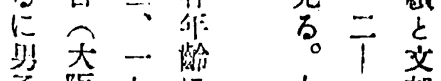

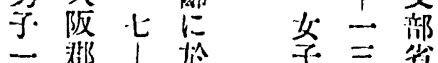

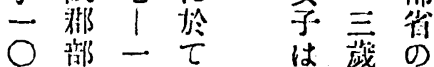

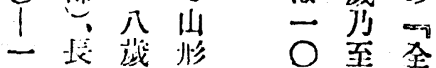

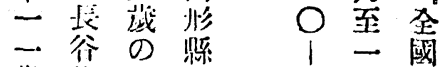

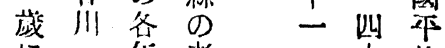

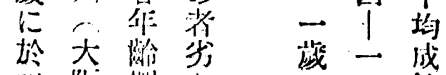

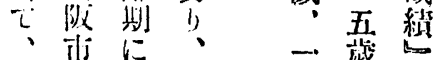

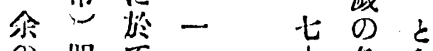

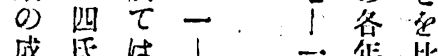
成比 1 年比

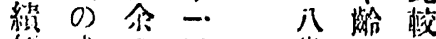

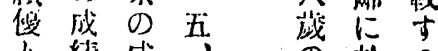

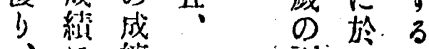

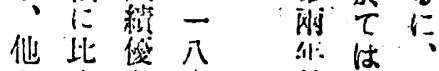

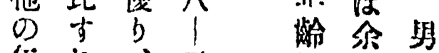

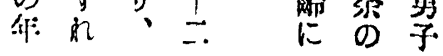




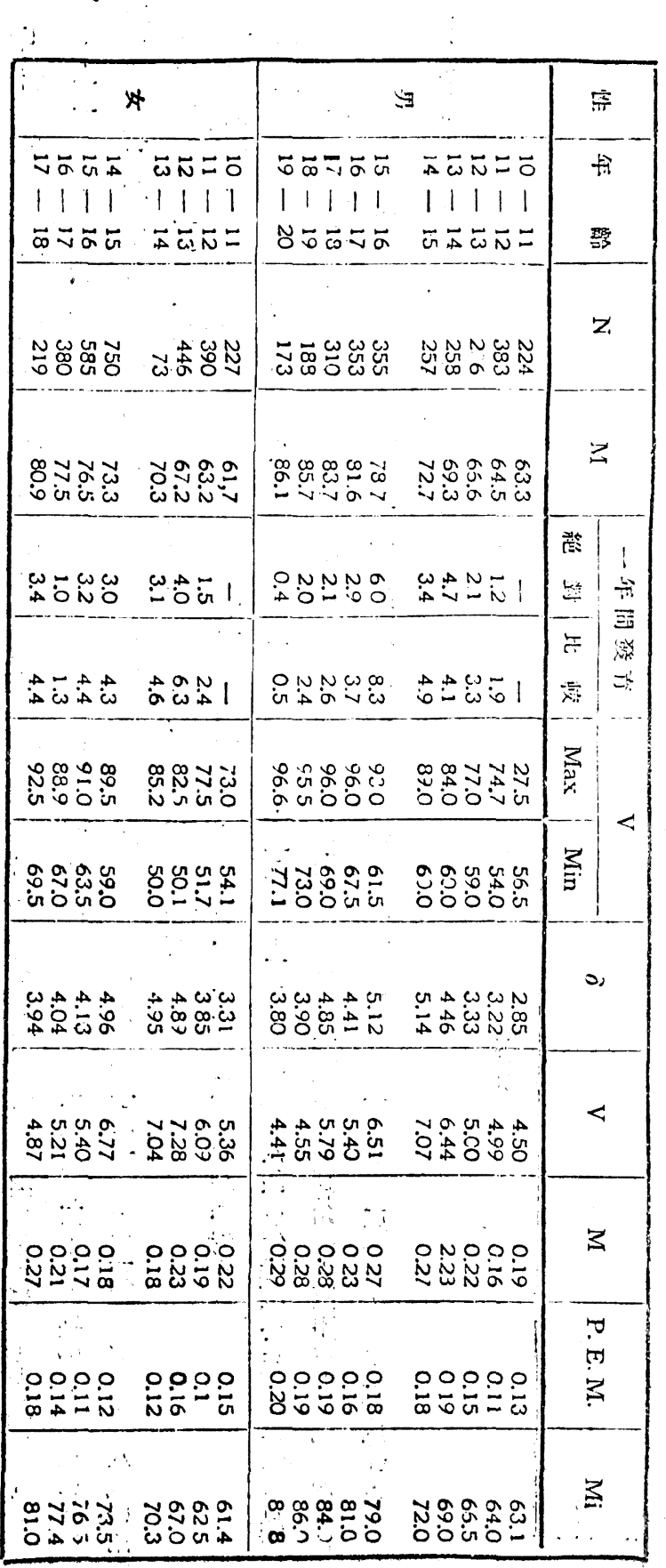

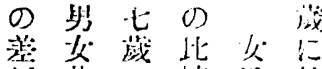

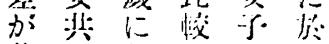

灌に於的一

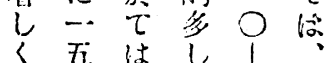

習 $\mathrm{M}$ - $\mathrm{M}$

吉

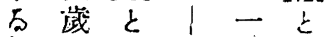

作店は二三は 䍩

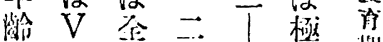

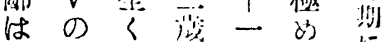

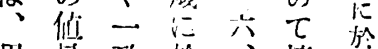

骂琵致於、接 的

子

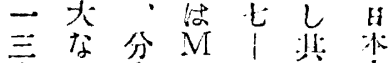

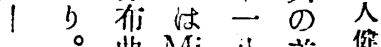

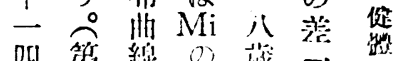

w

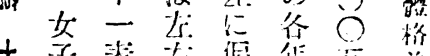

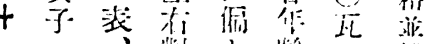

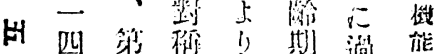

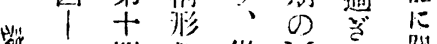

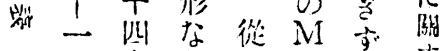

宛

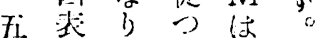

藏 寥。商

热㫮近、の

b)

。郎

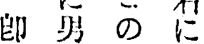

古炎 作 倫

二冬䍀

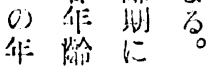

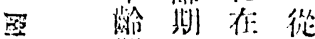

(I) $に \geqslant 0$

は於 $\tau \tau$

- 讨以 こ

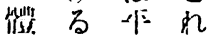

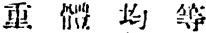

の III 数 0

獍 分占作

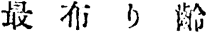

6 以劣阴

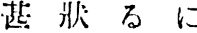

七沅架

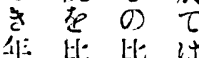

作比比

t

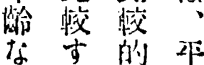

万名多均

に に装

齐拈一占

と六段

$\mathrm{Mi}$ 如 


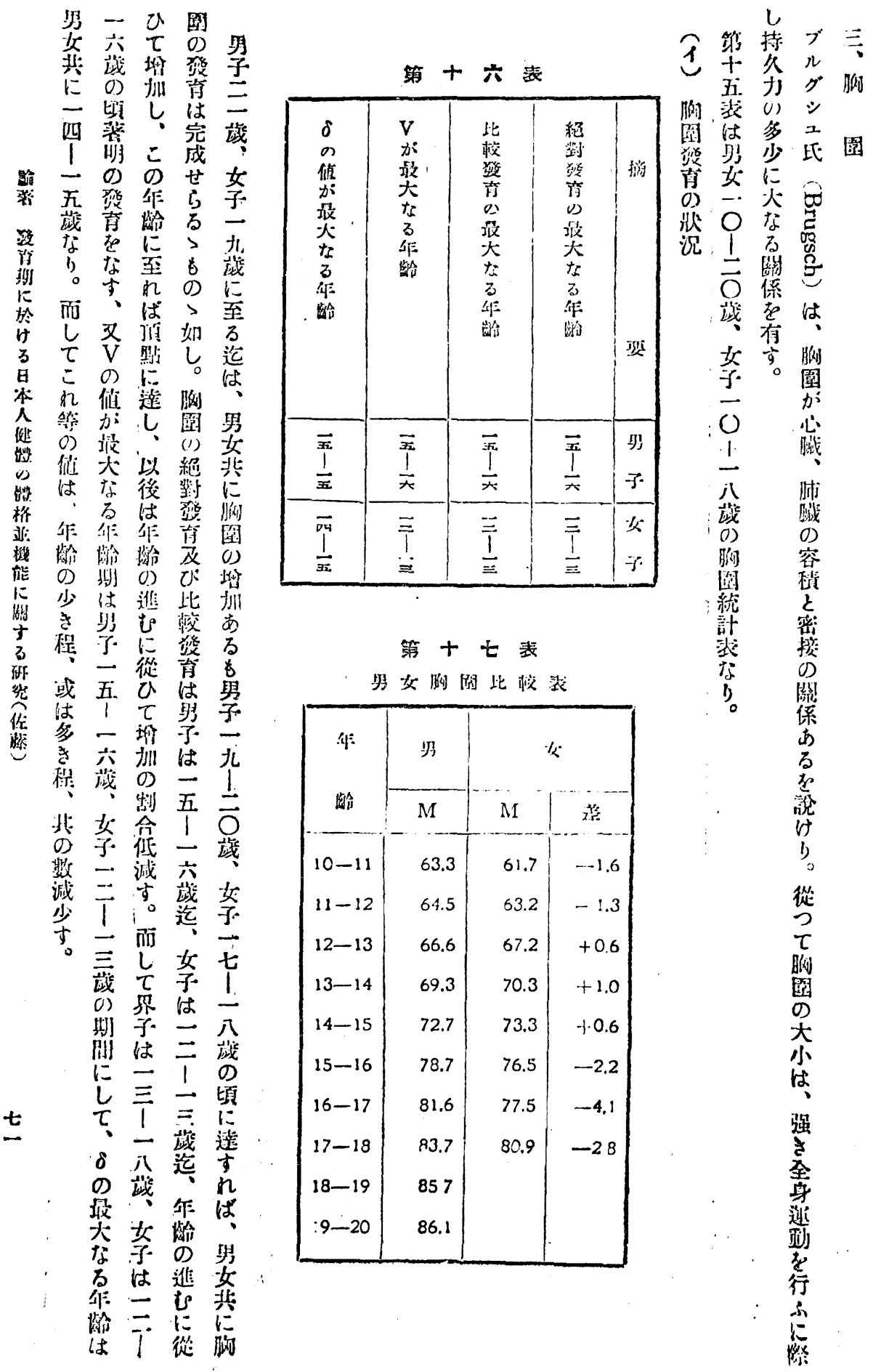


第 十八

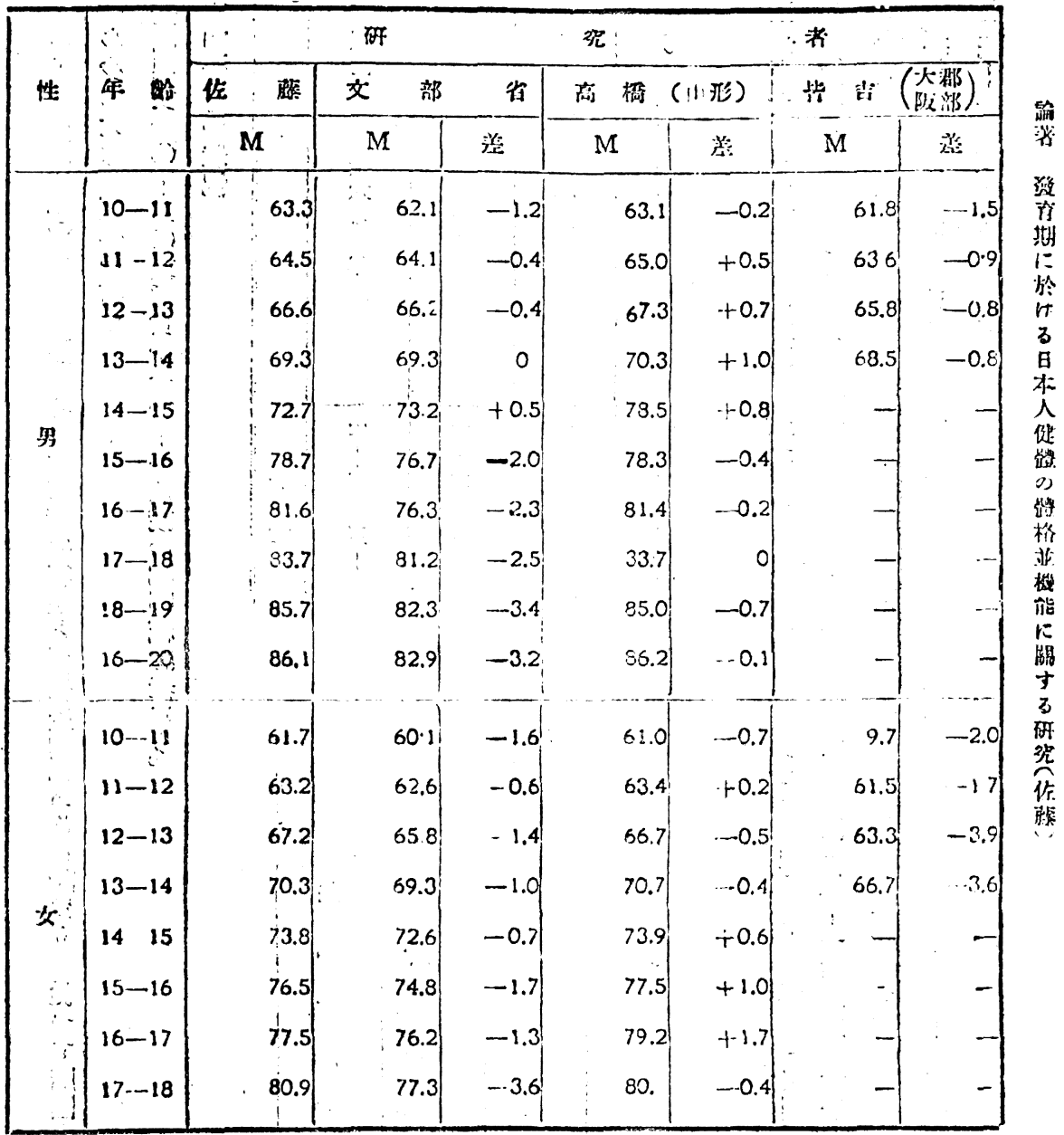

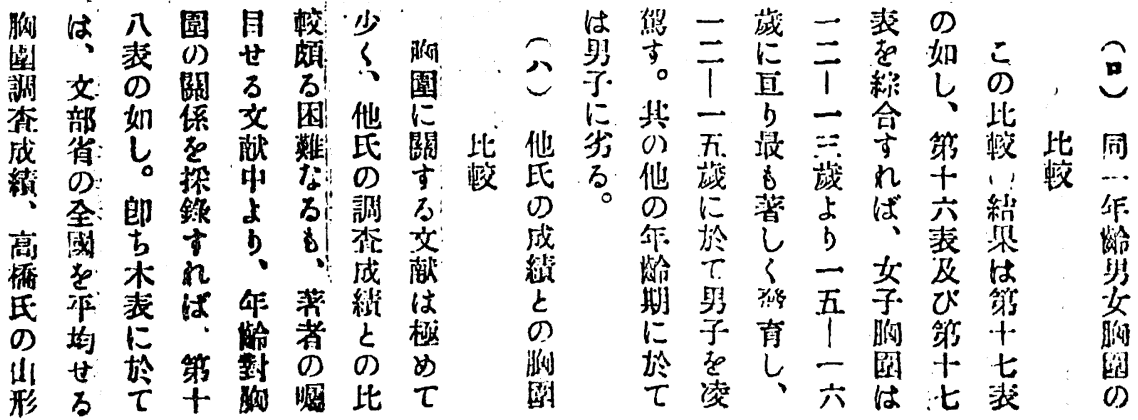




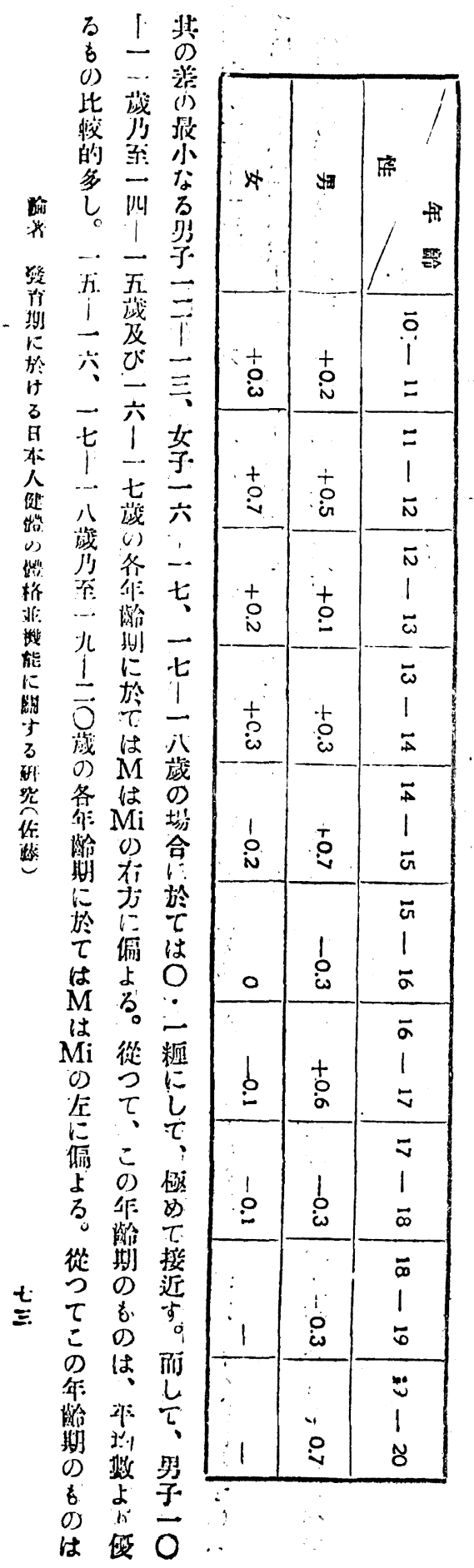

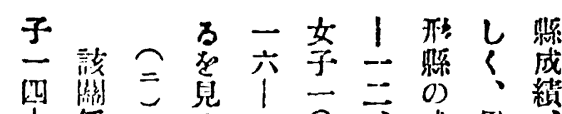

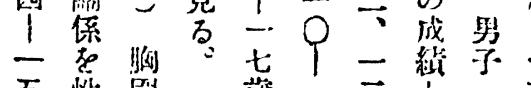

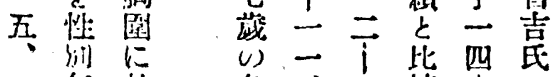

一年短各、上茭

九龄

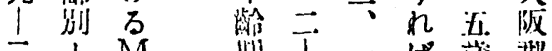

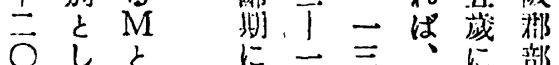

$\bigcirc<t \quad k 三 \equiv$

䇥

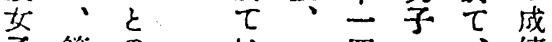

子第の は二四一、緭

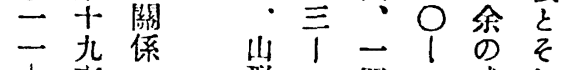

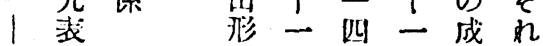

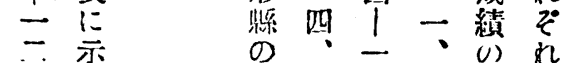

战夺省…五一少比

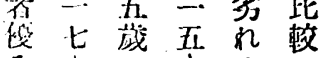

万人

- 各一の

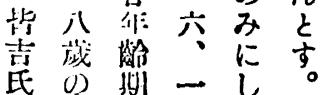

甾空元先

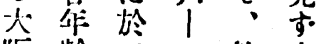

阪龄 $\tau$ 他妾

制城出部

部に非、易省

の坽將一女

些元心

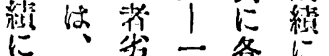

比余少元脌比

寸 0$)$, 嘴寺

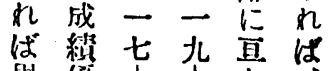

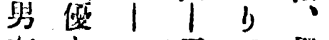

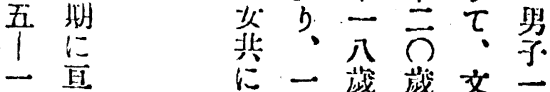

六古等些部三

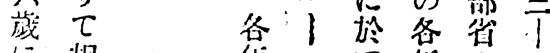

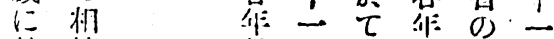

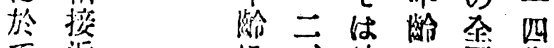

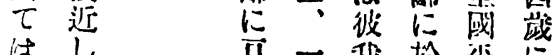

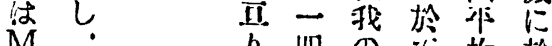

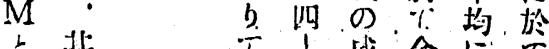

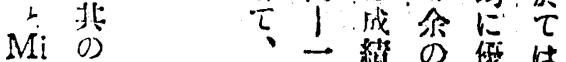

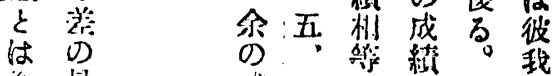

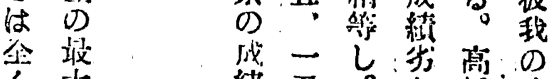

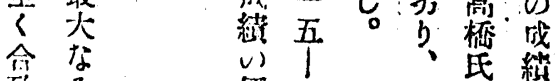

㮹盆㑧六二芯緗 


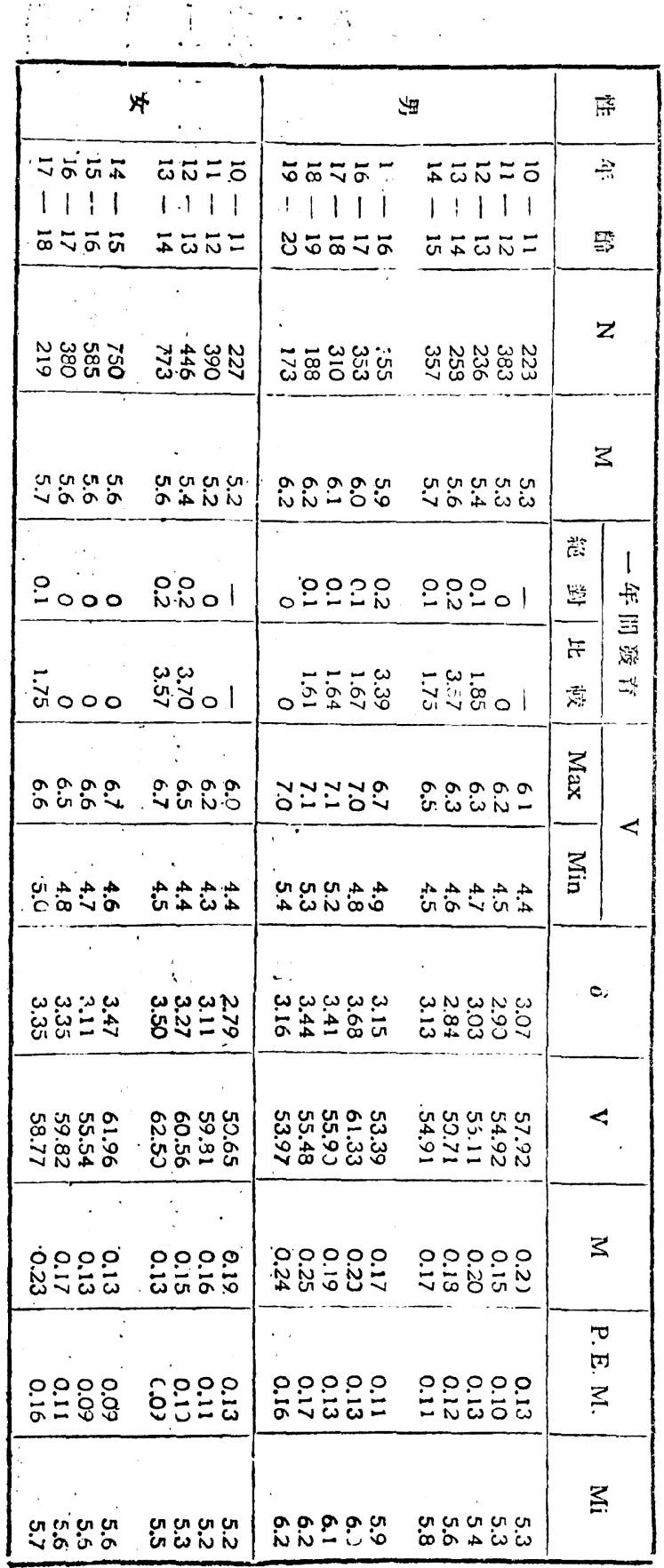

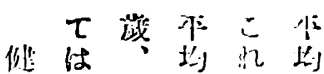

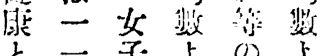

密 1 子

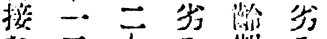

な二厂万则る

る、一专に省褕

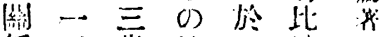

係三地地败

考 T 就

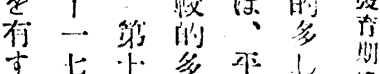

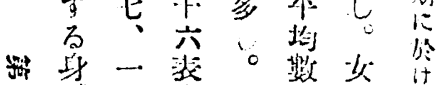

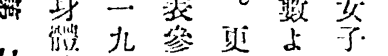

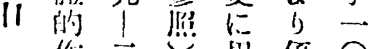

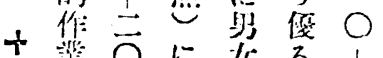

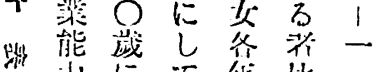

打に一桼此 -.. 蝶

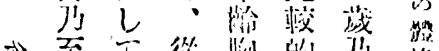

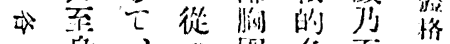

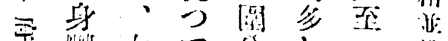

受

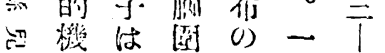

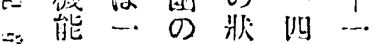

的

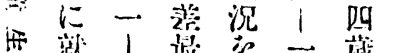

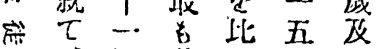

$\doteqdot$ 、叫迅较、ひ

收跕

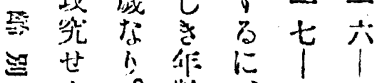

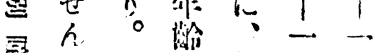

分小公七

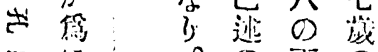

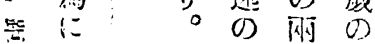

琶は， $\mathrm{M}$ 则作价

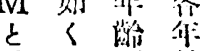

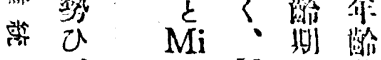

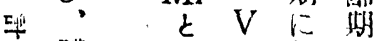

0) 0 於に

蓄位

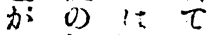

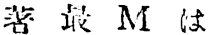

し天 は $M$

$<$ 惁 Mi k

塯る $の \mathrm{Mi}$

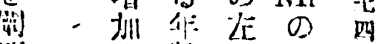

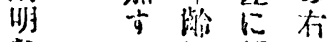

なる は俉经

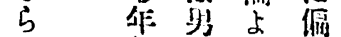

ᄂ 制

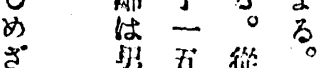

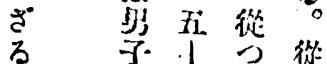

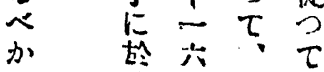




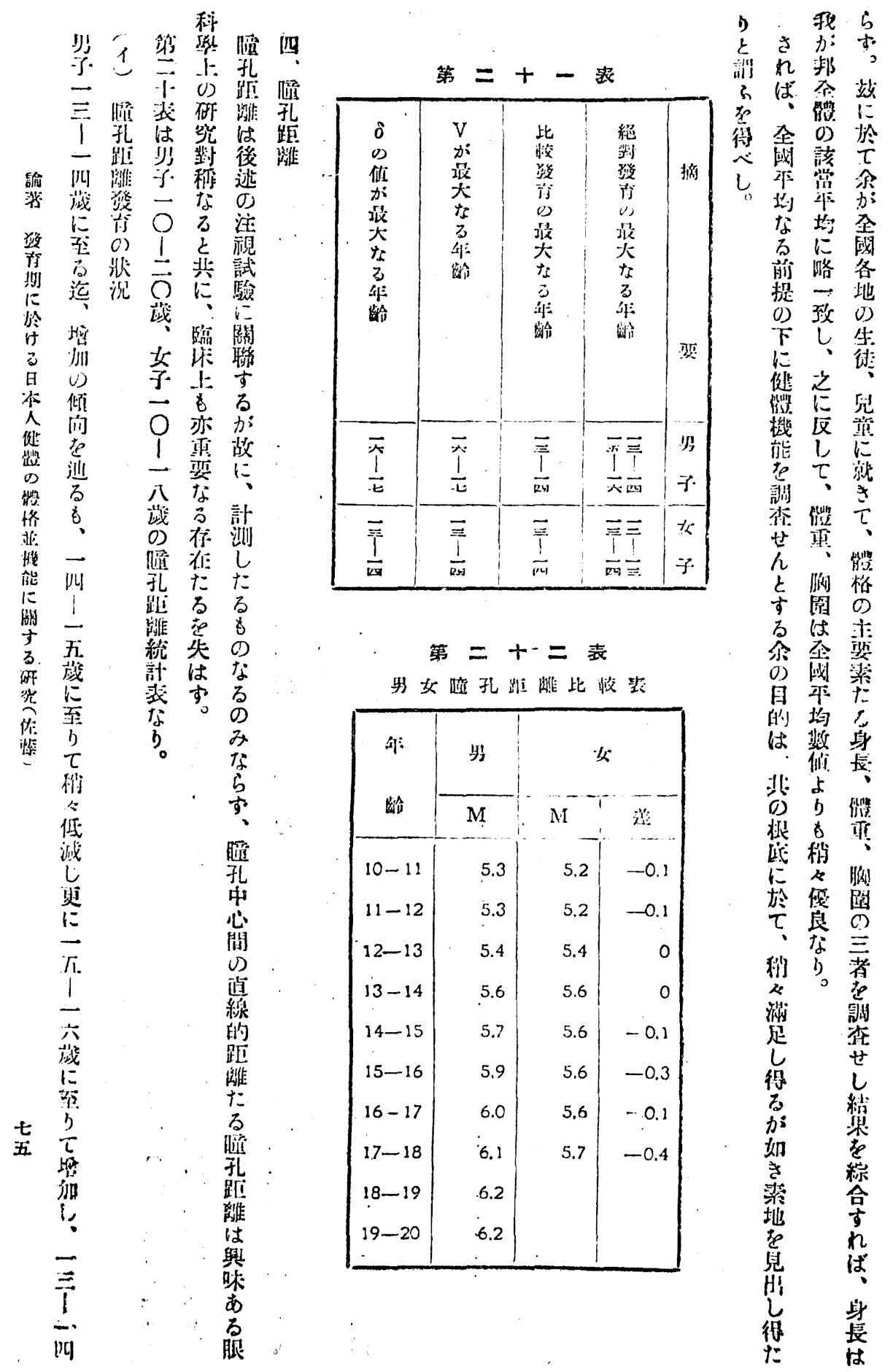




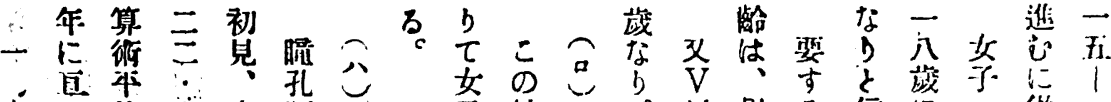

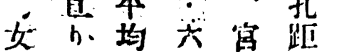

子成六歳卓雖他

に

此男 $\therefore$ 倠比㡭

し 专康の卞成

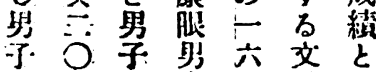

0) 五 - 女 1 献

䀷六八云は些

孚名

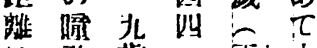

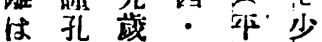

大距背文均?

な 䠰於六年他

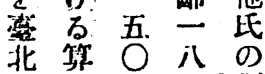

市郻名…䚴

に乎の杂烃

於均畩藏成

計 $\therefore$ 距

测 二䠰焦

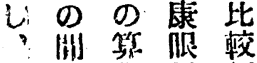

次很男襩

在 平㚣

如 引均訫困

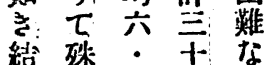

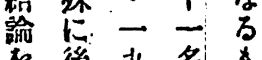

尔後杂名

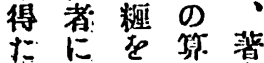

吉接得術著

。近た平 の

世方均吸

る。六自

與 $九$ 万

味は六文

あ何粕献

万骂 中

次

望势。探

留去吉

氏 1 初电

は元兒ば

正荿恕

八长和

年於均年

记方路

$$
\text { r }
$$

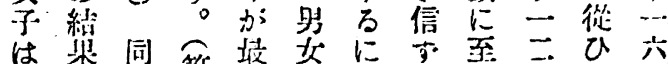

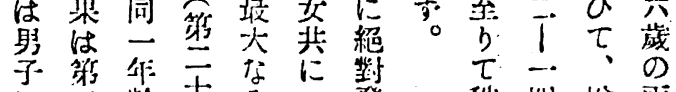

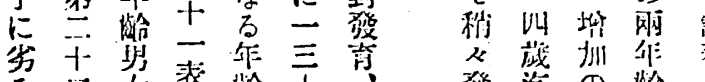

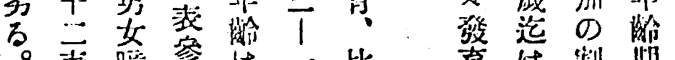

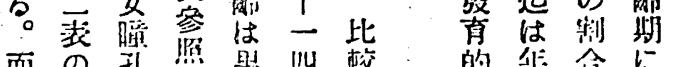

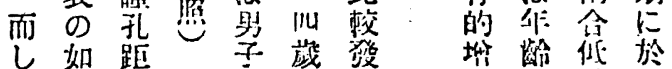

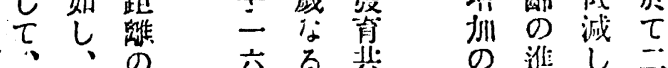

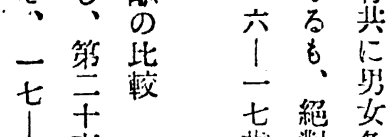

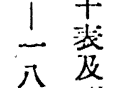

分茨

二 第

五

六䒾

焉綜

年. 拿

然

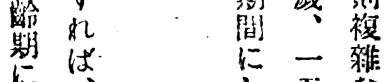

於二

其

の 四

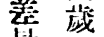

峧保

著於

し は

㛜

他 相

は 㓋

何证

$\stackrel{0}{0}$ 挫

の

粕他

0) 各

葬 很

以朝

劣百

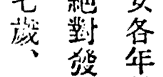

女简战命

子注朝

三次㤱

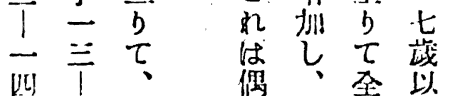

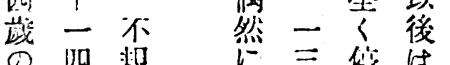

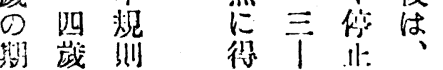

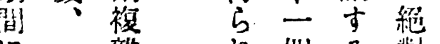

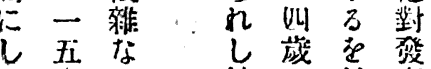

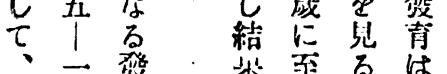

$\delta$ 六留：然柔る。

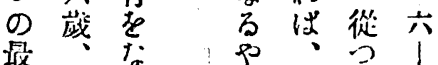

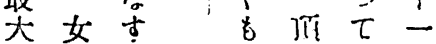

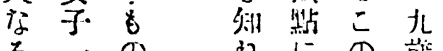

万- 0 就江战

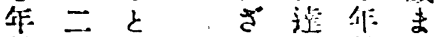

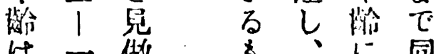

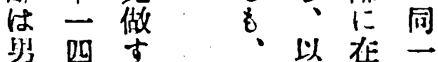

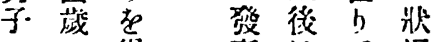

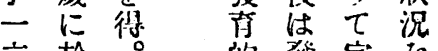

六於。的磞完展

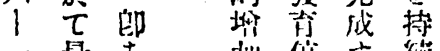

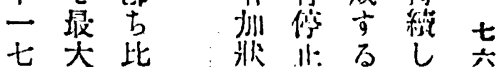

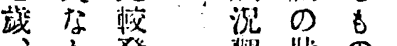

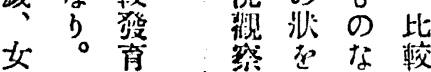

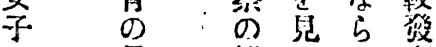

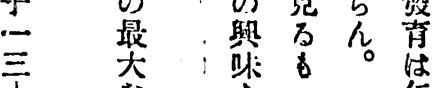

三 态: 喿。尔

四 作 : 敤 


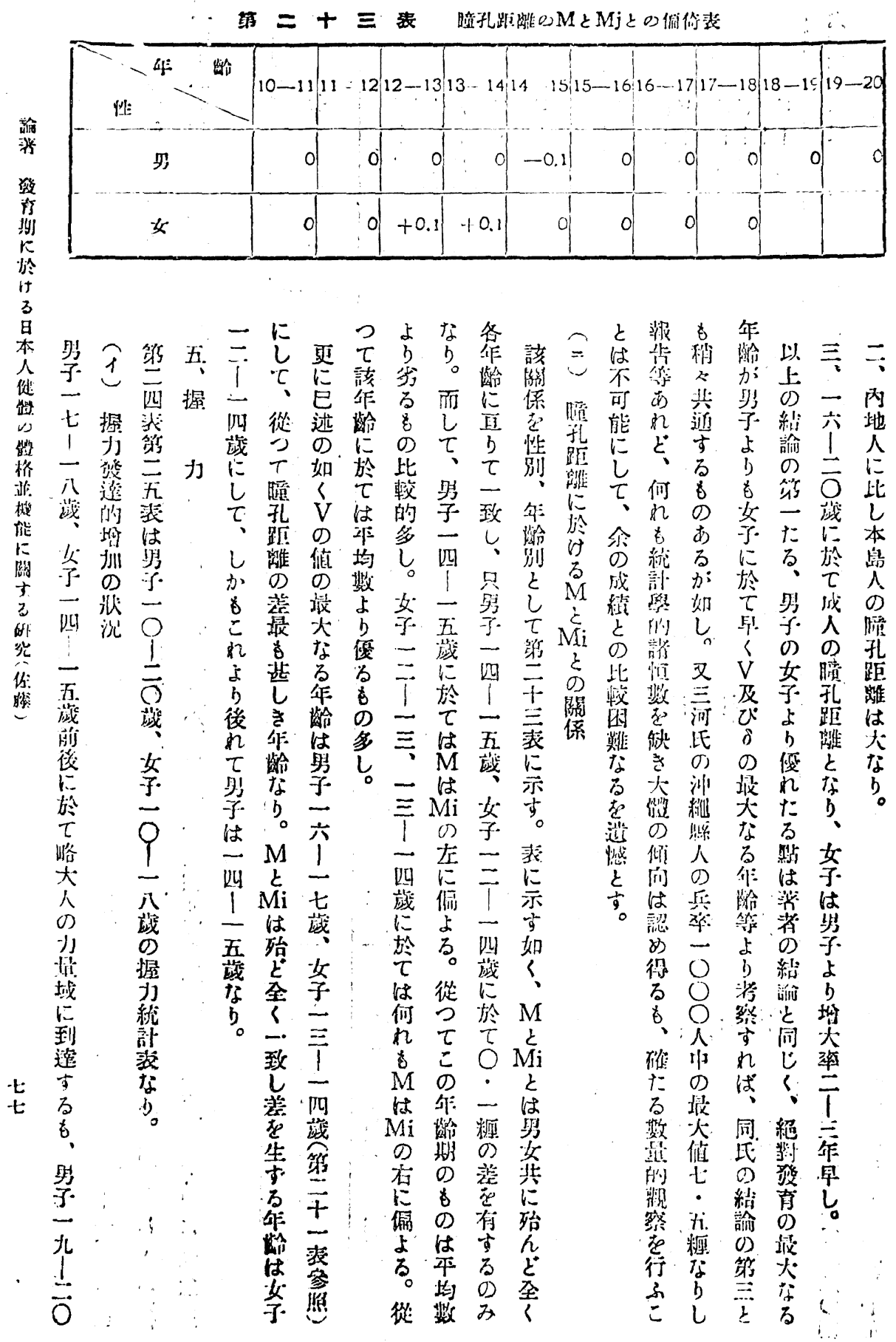




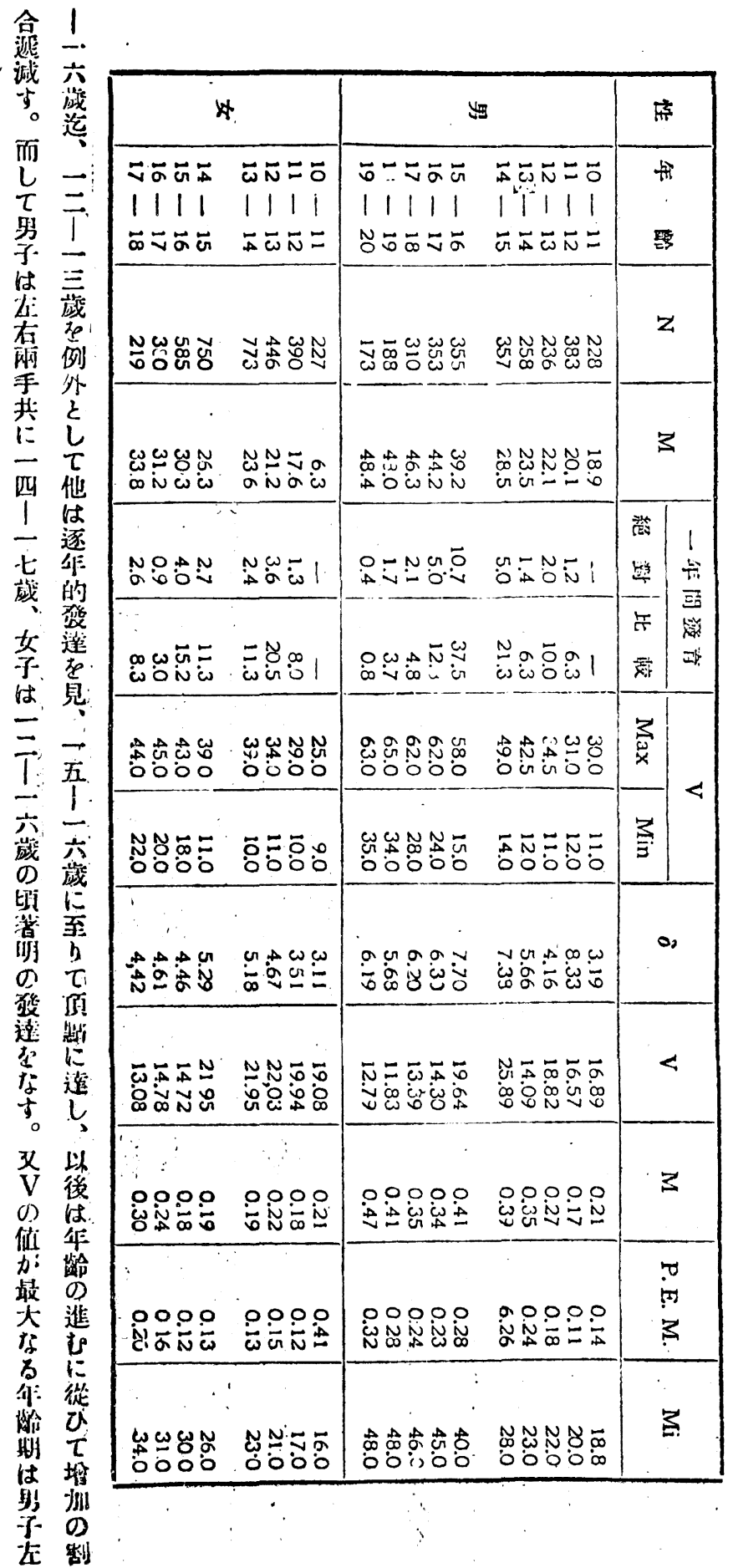

ま 万元城

一 捛少

五波し的。

$15=\vec{r}$

六作 |

荿〈龆一

迄篮问

遂盗至藏

俳 ᄂ 虹迄

的

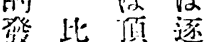

萨 校 黙 年

地湓に的

兒等造塯

热比势

後七自

は後る。

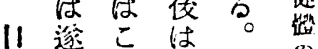

胙 9 行提

十的作紫方

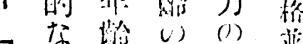

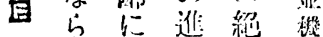

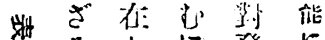

方尔從留

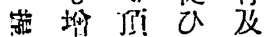

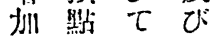

のに比

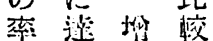

娍し 扣留

少、C) 有

古次制 は

絕 作合贸

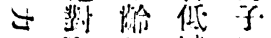

灌断娍如

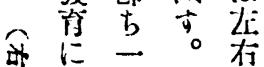

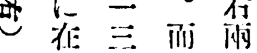

b 1 L 氺

$\tau$ - $\tau$ 其:

\& 烟少

比藏 等 -

粒には

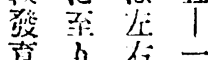

の涑公

綵娍手紫 $t$

之のに

秒 制 二 作

\& $\mathrm{A}$. 汾

似落门0

た 乙一非

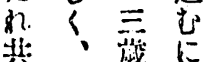

管以监煺

五後哥 U 


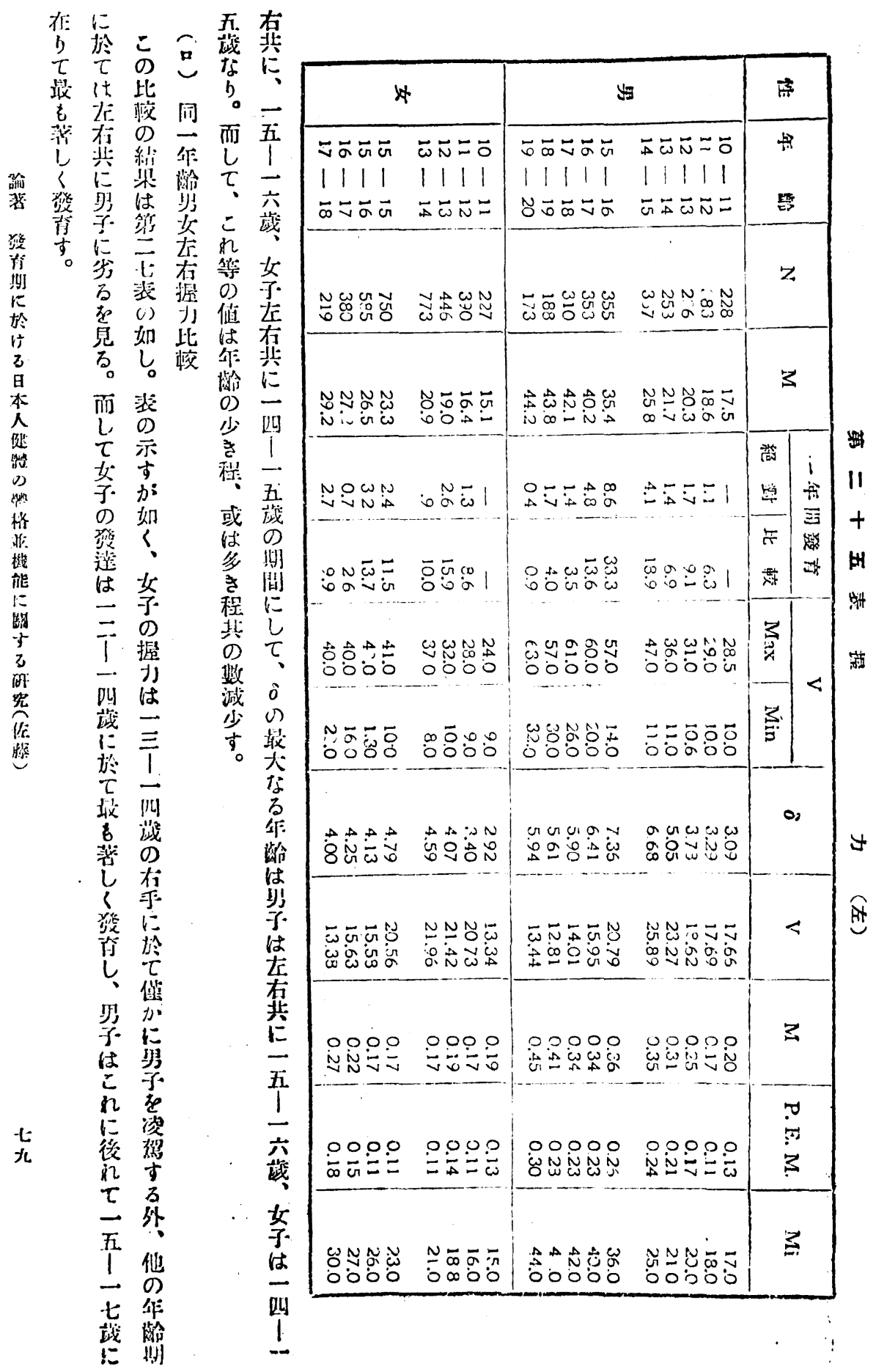




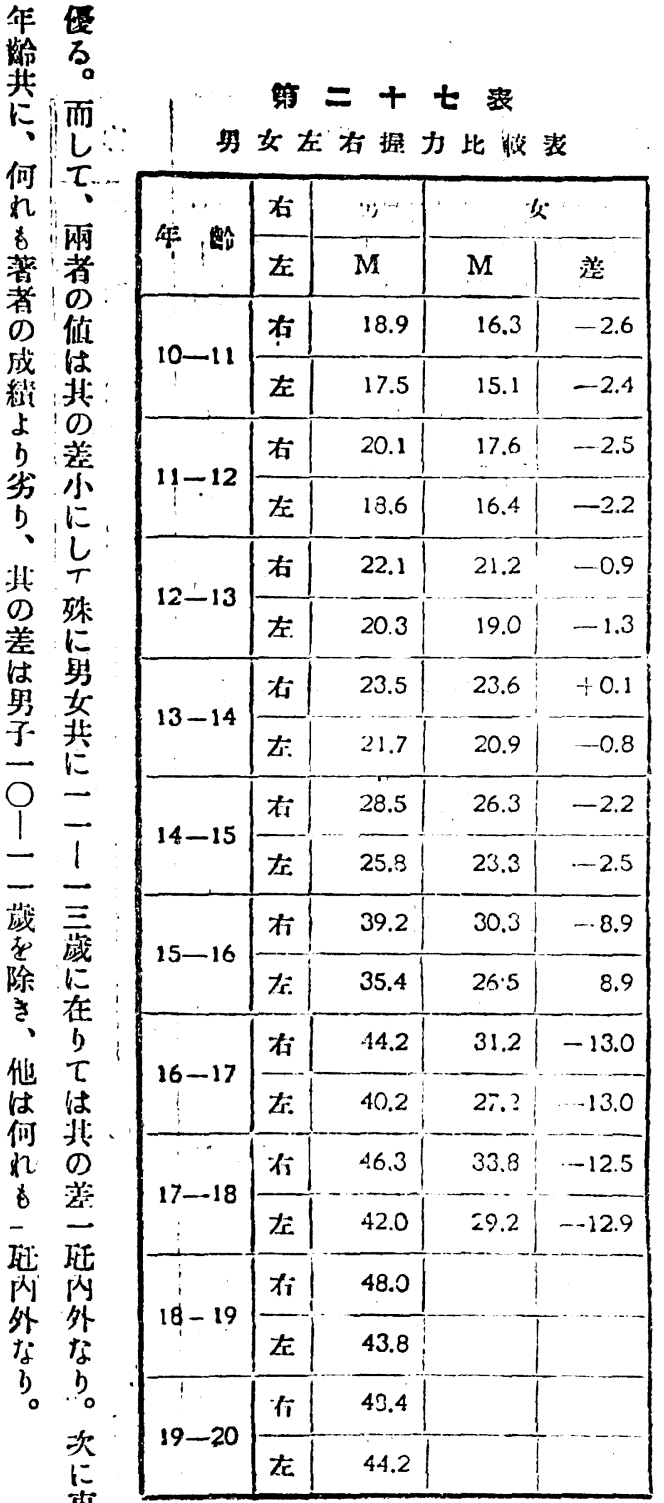

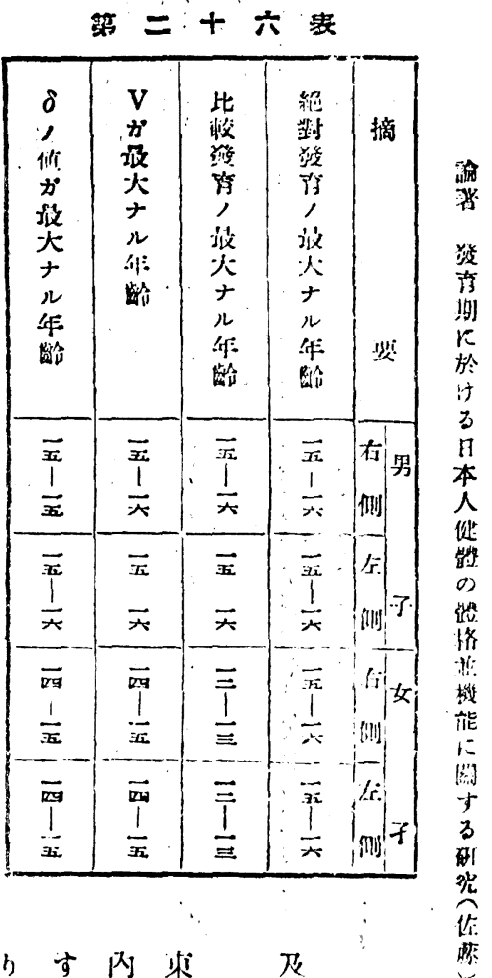

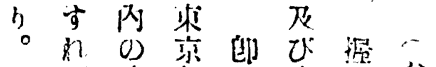
二优成郊古㷛少

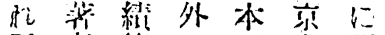

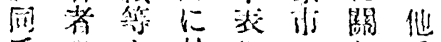
E $0<$ 於に心し代 は成々け就成七灰 $\exists$ 維れるて維如成 ル占飞成はと繶 ンb就維石此に 式落此及川留要多 し較ひ纸す数比 余くせ望のれ较

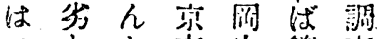

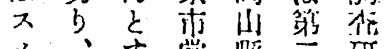

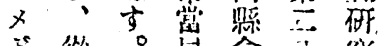
$F$ 從。者俞入栄

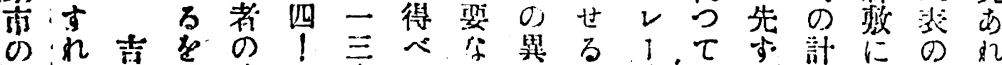

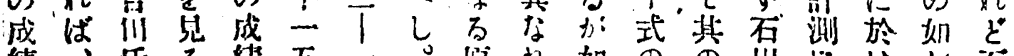

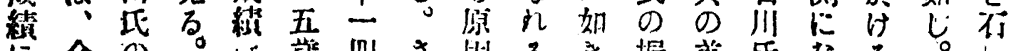

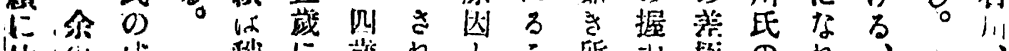

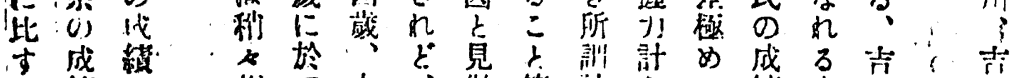

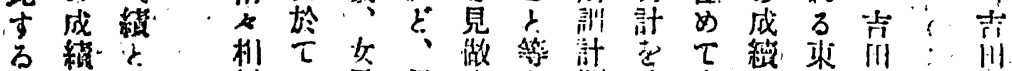

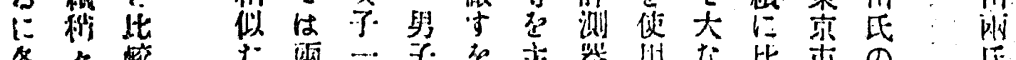

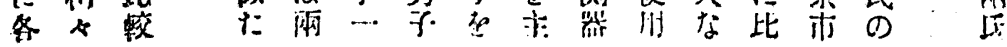


第二十八表他氏/握力成絽卜，比校

\begin{tabular}{|c|c|c|c|c|c|c|c|c|c|}
\hline \multirow{2}{*}{ 性 } & \multirow{2}{*}{ 年 蜍 } & \multirow{2}{*}{$\frac{\text { 右 }}{\text { tr }}$} & \multirow{2}{*}{ 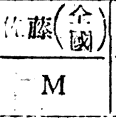 } & \multicolumn{2}{|c|}{ 不 川! (葫政) } & \multicolumn{2}{|c|}{ 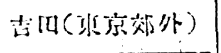 } & \multicolumn{2}{|c|}{ 就术(强术队) } \\
\hline & & & & M & 㔜 & $M$ & 瓶: & M! & 管 \\
\hline & 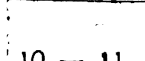 & 右 & 18.5 & 12.8 & -5.0 & 17.3 & -1.2 & 16.1 & $-2 \cdot 4$ \\
\hline & $10-1$ & tr. & 17.5 & 11.2 & -6.4 & 15.1 & 2.4 & 14.3 & -3.2 \\
\hline & & 右 & 20.1 & 14.5 & -5.5 & 13.9 & -1.2 & 18.6 & -1.5 \\
\hline & $\theta^{\circ}$ & 左 & 18.6 & 13.0 & -5.6 & $17 . c$ & -1.6 & 17.9 & -1.5 \\
\hline & 4 & $x_{i}$ & 22.1 & 19.8 & -2.3 & 21.6 & -0.5 & 20.2 & -1.9 \\
\hline & 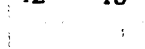 & 左 & 20.3 & 18.2 & -2.1 & 19.1 & -1.2 & 19.6 & -0.7 \\
\hline & & 们 & 23.5 & 224 & -1.1 & - & - & - & -- \\
\hline & $10-14$ & 左 & 21.7 & 20.5 & -1.2 & - & - & - & $\cdots$ \\
\hline & & 有 & 28.5 & 26.0 & -2.5 & - & - & - & $\cdots$ \\
\hline m & $\because$ & 左. & 25.8 & 24.4 & -1.4 & - & - &.- & -. \\
\hline & & 右 & 39.2 & 32.5 & -8.7 & -1 & - & - & - \\
\hline & . & ts. & 35.4 & 28.2 & -7.2 & - & - & - & - \\
\hline s & & 有 & 44.2 & 32.8 & -11.4 & - & - & -1 & - \\
\hline & $10 \div$ & t. & 40.2 & 31.0 & -9.2 & -1 & - & - & $\cdot$ \\
\hline & & 右 & 45.3 & 34.2 & -12.1 & & - & - & -- \\
\hline & $11-10$ & tr: & 42.1 & 31.5 & -10.6 & $\ldots$ & - & - & - \\
\hline & & 右 & 48.0 & - & - & - & - & - & -- \\
\hline & $10-.7$ & 左 & 43.8 & -1 & - & - & - & - & - \\
\hline & & 有 & 48.4 & - & - & - & - & - & - \\
\hline & $17 \div$ & 応 & 44.2 & - & - & - & - & - & - \\
\hline & & 右 & 16.3 & 9.7 & -6.6 & 153 & $-1,0$ & .15 .4 & $-0 . \lambda$ \\
\hline & $10 \div 22$ & tr. & 15.1 & 8.2 & -6.9 & 13.1 & $-2,0$ & 13.5 & -1.6 \\
\hline & & 存 & 17.6 & 11.6 & 6.0 & 17.4 & $-0,2$ & 16.4 & -1.2 \\
\hline & $11 T 12$ & 左. & 16.4 & 9.7 & -6.7 & 15.5 & -0.9 & $\because 15.4$ & -1.0 \\
\hline & $\cdots$ & 右 & 21.2 & 16.4 & -4.8 & 20.4 & $-0,8$ & 20.2 & -1.0 \\
\hline & $12 \div 30$ & 库 & 19.0 & 14.7 & -4.3 & 17.4 & $-1: 6$ & 17.7 & -1.3 \\
\hline
\end{tabular}




\begin{tabular}{|c|c|c|c|c|c|c|c|c|c|}
\hline \multirow{2}{*}{. 吽: } & \multirow{2}{*}{ 年䍉 } & \multirow{2}{*}{$\frac{t}{t}$} & \multirow{2}{*}{ 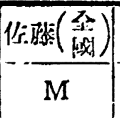 } & \multicolumn{2}{|c|}{ 石 川 (余数) } & \multicolumn{2}{|c|}{ 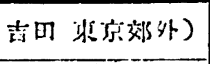 } & \multicolumn{2}{|c|}{ 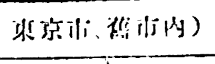 } \\
\hline & & & & M & 祦 & $\mathrm{M}$ & 些: & $\mathbf{M}$ & 致: \\
\hline \multirow{10}{*}{ 女 } & \multirow{2}{*}{$13-14$} & 右 & 23.6 & 19.0 & -4.6 & - & - & - & - \\
\hline & & $\not r$ & 20.9 & 17.1 & -3.8 & -- & - & - & - \\
\hline & \multirow{2}{*}{$14-15$} & 右 & 26.3 & 22.6 & -3.7 & - & - & - & - \\
\hline & & to & 23.3 & 20.3 & -3.0 & - & - & - & - \\
\hline & \multirow{2}{*}{$15-16$} & 右 & 30.3 & 23.5 & -6.8 & - & - & - & - \\
\hline & & tr. & 26.5 & 2.4 & -5.1 & - & - & - & - \\
\hline & \multirow{2}{*}{$16-17$} & 右 & 31.2 & 23,4 & -7.8 & - & - & - & - \\
\hline & & tr & 27.2 & 21.4 & -5.8 & - & - & - & $\cdots$ \\
\hline & \multirow{2}{*}{$17-18$} & 右 & 33.8 & - & - & - & - & - & - \\
\hline & & tr. & 29.2 & - & - & - & - & - & $\cdots$ \\
\hline
\end{tabular}

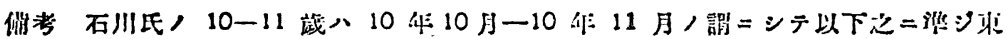

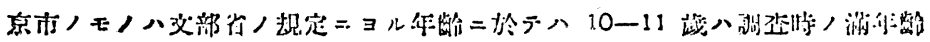

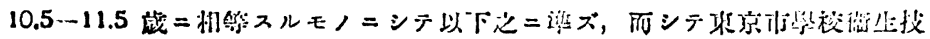

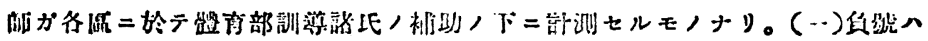

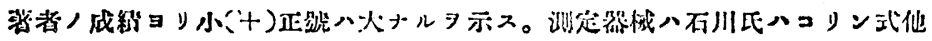

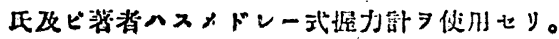

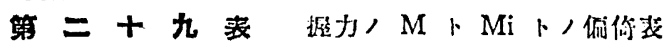

\begin{tabular}{|c|c|c|c|c|c|c|c|c|c|c|c|}
\hline 性: & 㻟 & $10-11$ & $11-12$ & $12-13$ & $13-14$ & $\mid 4-15$ & $15-16$ & $16-17$ & $17-18$ & $|18-19|$ & $19-20$ \\
\hline \multirow{2}{*}{ 多 } & 右 & +0.1 & +0.1 & +0.1 & +0.5 & +0.5 & -0.8 & -0.8 & +0.3 & o & +0.4 \\
\hline & ta. & +0.5 & +0.6 & +0.3 & +0.7 & +0.8 & -0.6 & +0.2 & +0.1 & -0.2 & +0.2 \\
\hline \multirow{2}{*}{ th } & 右 & +0.3 & +0.6 & +0.2 & +0.6 & +0.3 & +0.3 & +0.2 & -0.2 & - & - \\
\hline & 在 & +0.1 & $\begin{array}{l}+0.4 \\
\end{array}$ & +0.2 & -0.1 & +0.3 & +0.5 & +0.2 & -0.8 & - & - \\
\hline
\end{tabular}




\section{IV 䓡 193}

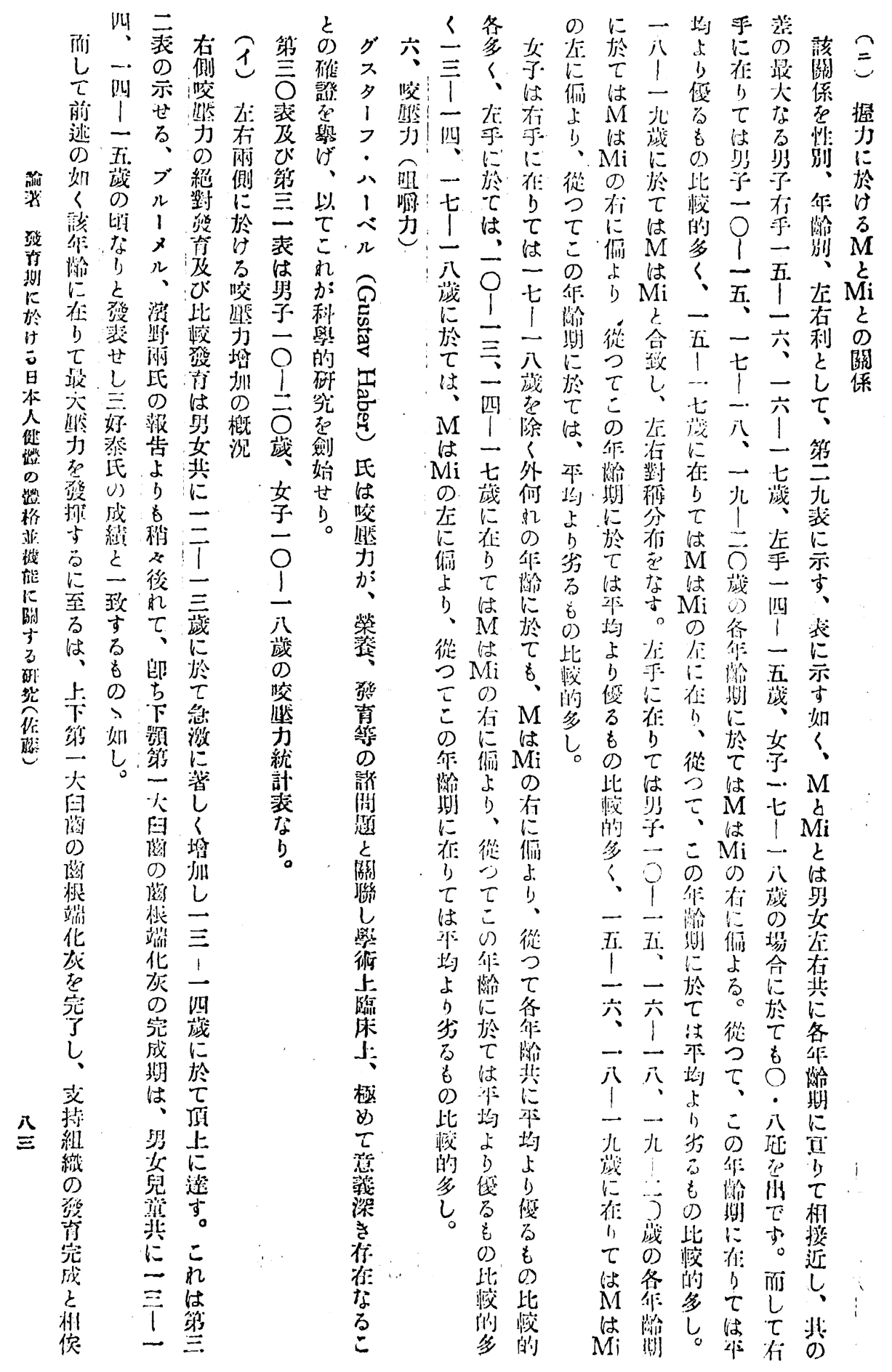




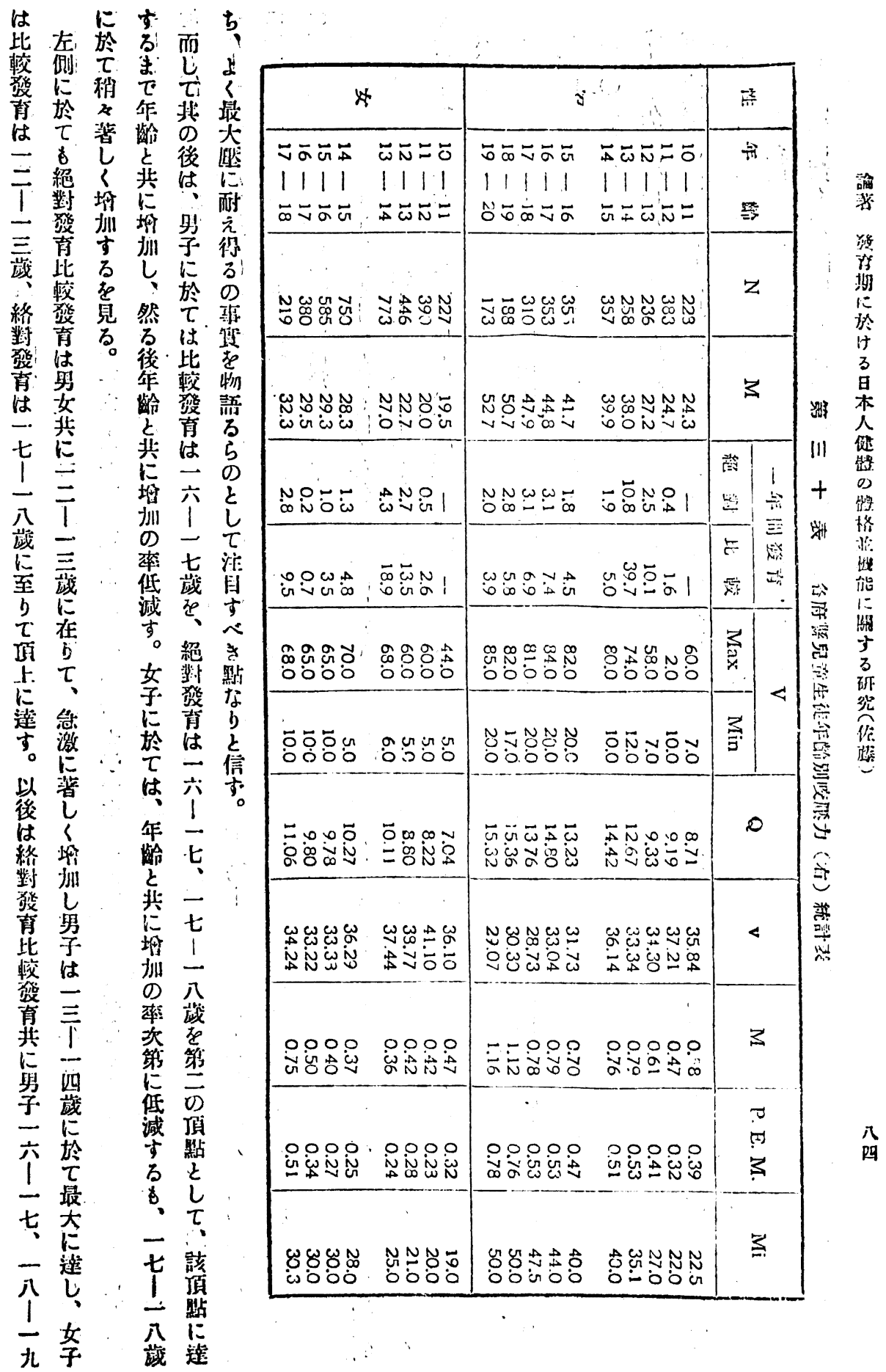


IV $19 \mathrm{~s}$

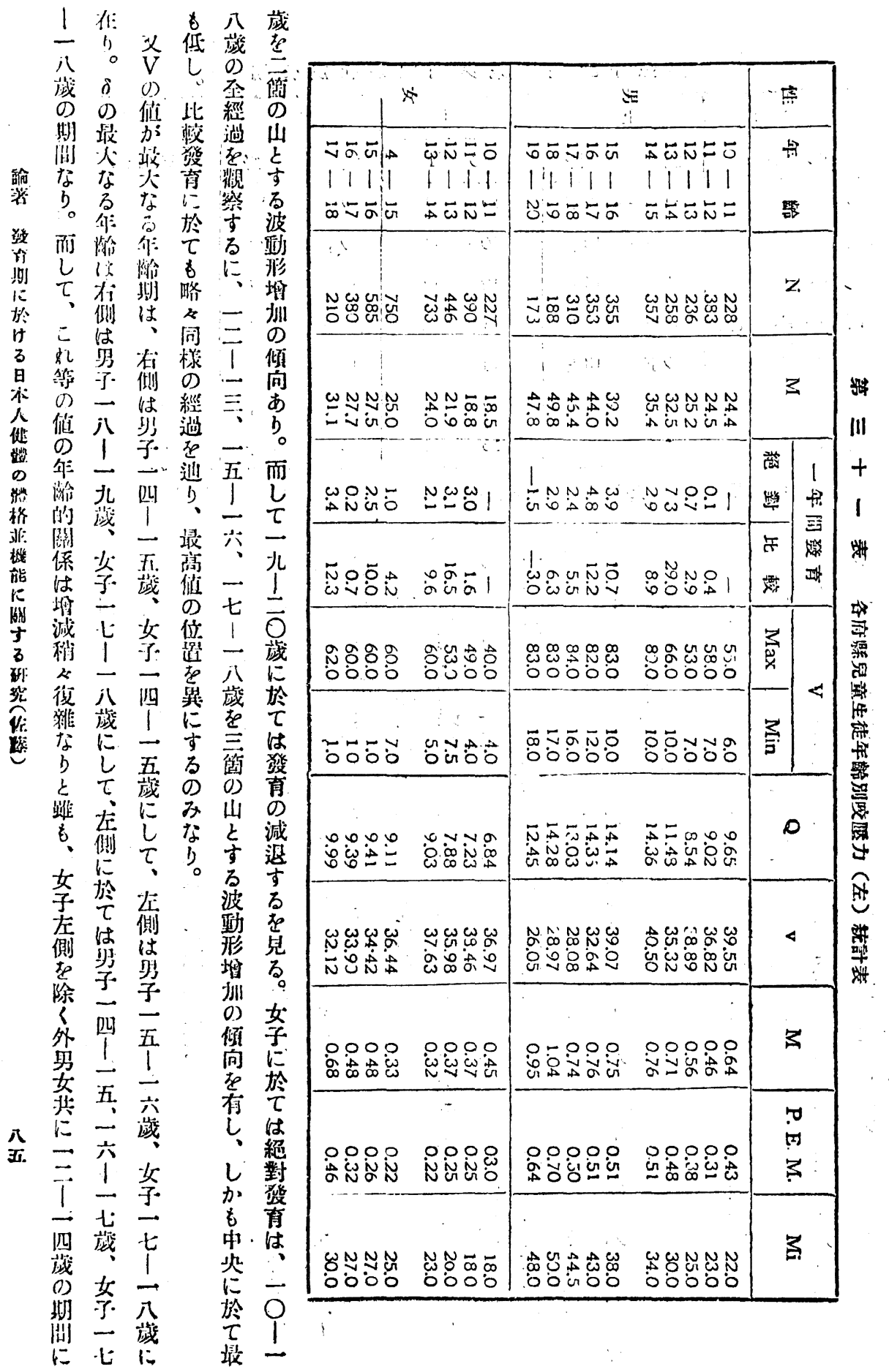




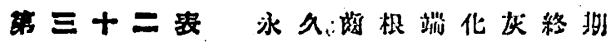

\begin{tabular}{|c|c|c|c|c|}
\hline \multirow{2}{*}{ 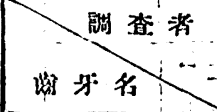 } & 上. & 颚 & F & 散 \\
\hline & 溜 野 & Bromell & 湤 & Bromell \\
\hline 川 切 偲 & 11上-12下 & $10-11$ & $9 F-10$ & 10 \\
\hline 㑬 切 ${ }^{-1}$ 药 & $11 F-12 F$ & $10-11$ & $9 \%-12 \%$ & $10-11$ \\
\hline 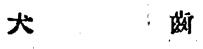 & 13下 - 15上 & $12-13$ & $13 F-15 J=$ & $12-13$ \\
\hline 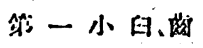 & 14ل الـ & $11-12$ & $13 \mathrm{l}:-15$. & $11-12$ \\
\hline 访 二小白壿 & $9 F-13\rfloor$ & $11-12$ & $13 \mathrm{~J}:-15\rfloor$ & $11-12$ \\
\hline 笴一大白路 & $15 F-.16 \%$ & $9-10$ & $9 F-11 F$ & $9-10$ \\
\hline 纺二火白缺 & & $16-18$ & $15 上-16 F$ & $16-17$ \\
\hline
\end{tabular}

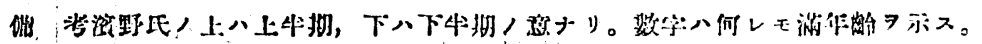

し三㟔

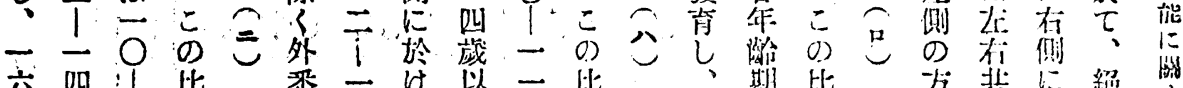

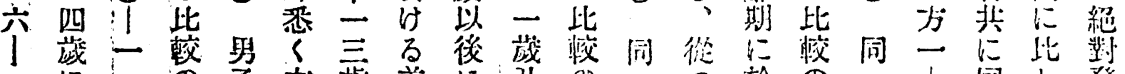

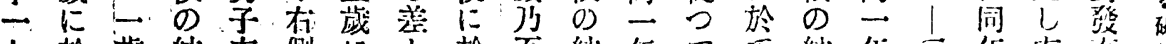

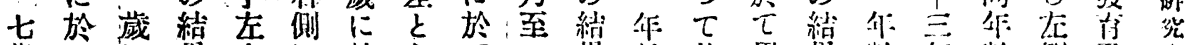

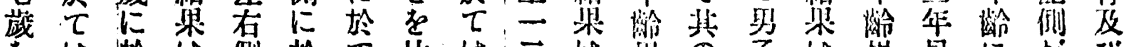

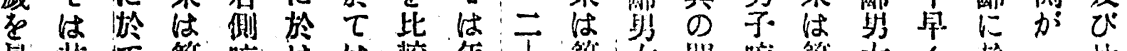

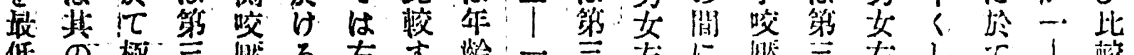

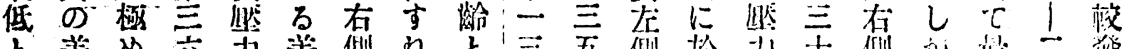

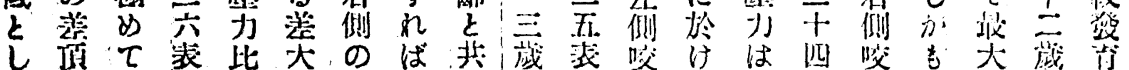

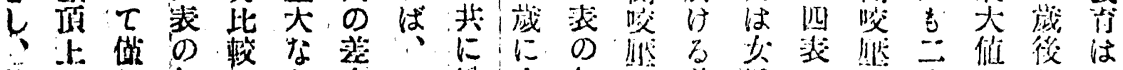

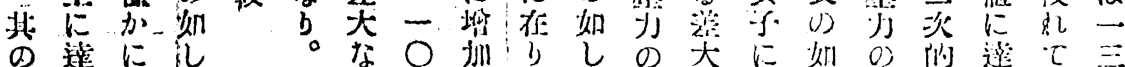

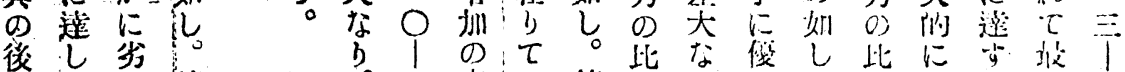

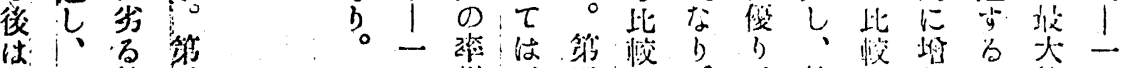

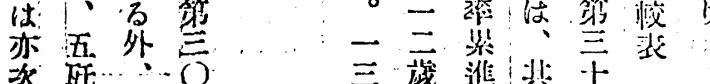

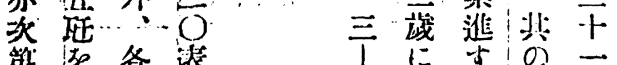

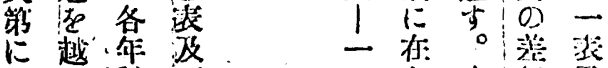

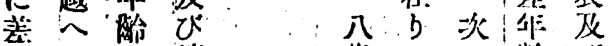

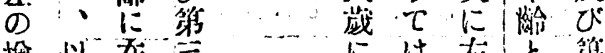

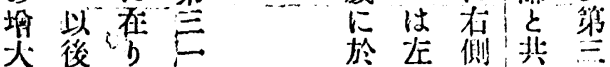

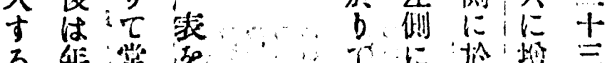

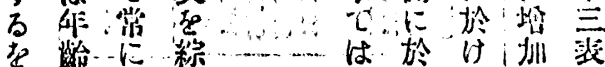

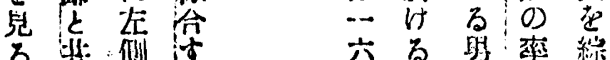

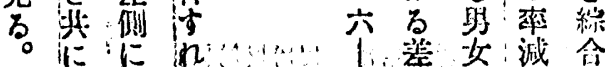

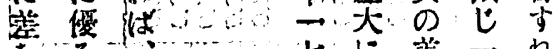

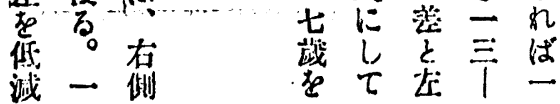

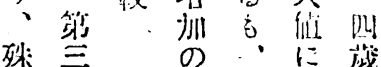
心干倾之䢰に

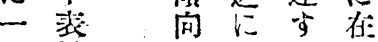

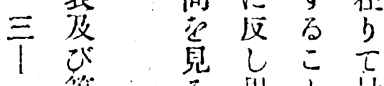

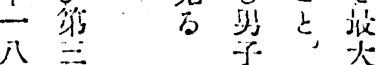

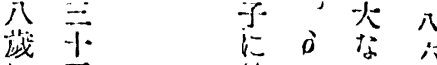

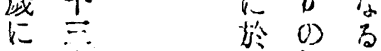
II. 琵宁们 b点枯方衣 枝合有宁 V 和测に

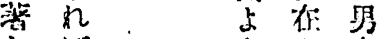


IV 然 297

第三十五敦

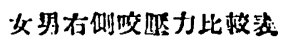

\begin{tabular}{|c|c|c|c|}
\hline \multirow{2}{*}{$4 \div$} & 㭁 & \multicolumn{2}{|c|}{ 女 } \\
\hline & M & M & 薜 \\
\hline $10-11$ & 24.4 & 18.5 & -5.9 \\
\hline $11-12$ & 24.5 & 18.8 & -5.7 \\
\hline $12-13$ & 25.2 & 21.9 & -3.3 \\
\hline $13-14$ & 325 & 24.0 & -8.5 \\
\hline $13-15$ & 35.4 & 25.0 & -10.4 \\
\hline $15-16$ & 39.2 & 27.5 & -11.7 \\
\hline $16-17$ & 44.0 & 27.7 & -16.3 \\
\hline $17-18$ & 46.4 & 31,1 & -15.3 \\
\hline $18-19$ & 49.3 & & \\
\hline $19-20$ & 47.8 & & \\
\hline
\end{tabular}

第三十六贵

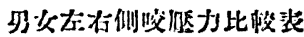

\begin{tabular}{|c|c|c|c|}
\hline \multirow{2}{*}{ 们: 缷 } & 行 & \multicolumn{2}{|c|}{$\%$} \\
\hline & M & M & 站 \\
\hline $10-11$ & 24.3 & 24.4 & +01 \\
\hline $11-12$ & 24.7 & 24.5 & -0.2 \\
\hline $12-13$ & 27.2 & 25.2 & -2.0 \\
\hline $13-14$ & 38.0 & 32.5 & --5.5 \\
\hline $14-15$ & 39.9 & 35.4 & -4.5 \\
\hline $15-16$ & $4 ! .7$ & 39.2 & -2.5 \\
\hline $16-17$ & 44.8 & 44.0 & -08 \\
\hline $17-18$ & 47.9 & 46.4 & -1.5 \\
\hline $18-19$ & 50.7 & 49.3 & -1.4 \\
\hline $19-20$ & 52.7 & 47.8 & -4.9 \\
\hline
\end{tabular}

第三十三

\begin{tabular}{|c|c|c|c|c|c|}
\hline 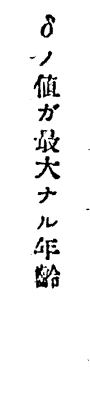 & 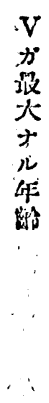 & 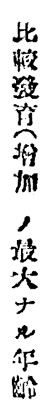 & 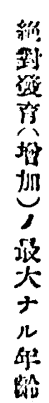 & & \\
\hline$: \frac{\vec{\imath}}{r}$ & $\frac{1}{10}$ & $\frac{\overrightarrow{1}}{\frac{1}{2 Q 1}}$ & $\frac{\overrightarrow{1}}{49}$ & $x_{i}$ & נ \\
\hline 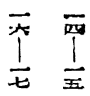 & $\frac{\vec{\pi}}{\frac{\pi}{\pi}}$ & $\frac{\overline{1}}{124}$ & $\frac{\vec{\equiv}}{\frac{1}{u t}}$ & $\begin{array}{l}\text { t5. } \\
\text { (iIII) }\end{array}$ & 子 \\
\hline$\frac{\pi}{1}$ & $\frac{\overline{1}}{\overline{v i}}$ & $\frac{\overrightarrow{1}}{i x}$ & $\frac{\overrightarrow{1}}{\frac{1}{00}}$ & $\begin{array}{l}\text { 右 } \\
\text { 侧 }\end{array}$ & 女 \\
\hline$\frac{E}{i}$ & $\underset{i}{\vec{E}}$ & $\stackrel{1}{\equiv}$ & $\frac{i}{\pi}$ & 侧 & -7 \\
\hline
\end{tabular}

第三十四嘅

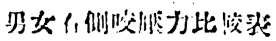

\begin{tabular}{|c|c|c|c|}
\hline \multirow{2}{*}{ 作: 獣 } & $! 3$ & \multicolumn{2}{|c|}{ 《 } \\
\hline & $M$ & $M$ & 淀 \\
\hline $10-11$ & 24.3 & 19,5 & -4.8 \\
\hline $11-12$ & 24.7 & 20.0 & -4.7 \\
\hline $12-13$ & 27.2 & 22.7 & -4.5 \\
\hline $13-14$ & 38.0 & 27.0 & -110 \\
\hline $14-15$ & 39.9 & 283 & -11.6 \\
\hline $15-16$ & 41,7 & 29.3 & -12.4 \\
\hline $16-17$ & 14,8 & 295 & -15.3 \\
\hline $17 \ldots 18$ & 47.9 & 32.3 & -15.6 \\
\hline $18-19$ & $5 \%, 7$ & & t \\
\hline $19-20$ & 527 & & \\
\hline
\end{tabular}




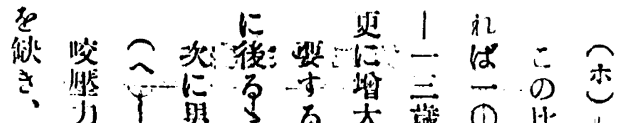

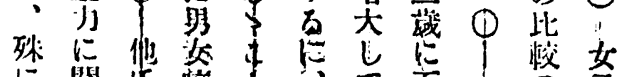

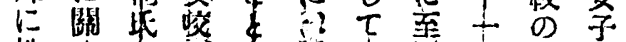

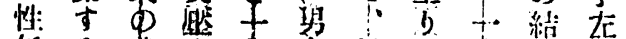

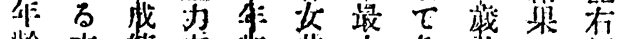

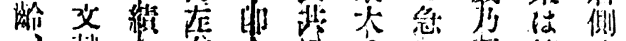

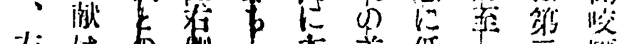

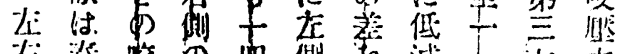

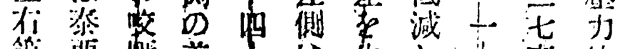

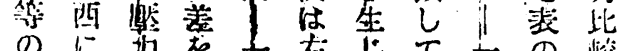

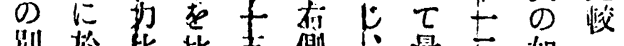

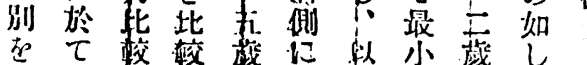

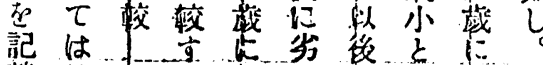
㭜比. 济在当

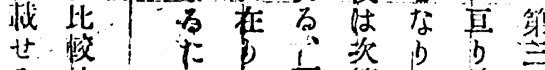

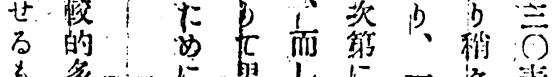

の

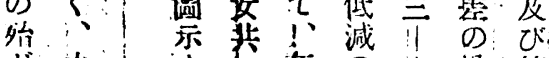

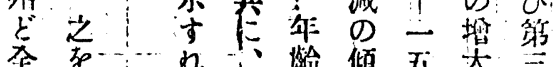

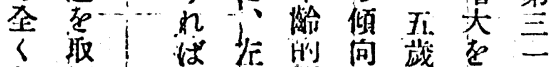

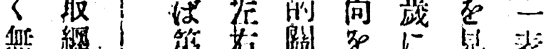

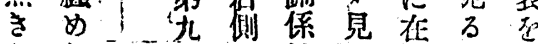

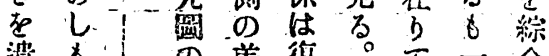

遗。考復。元二合

蝛の 如

吉第皆最占

路突

つ表

七。

束， 邦。

旅

讨

万悲

文に

献 示

就市

㒻?

万们

尔陫, 裙

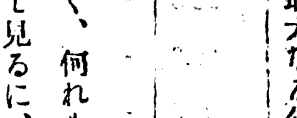

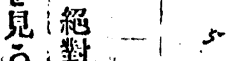

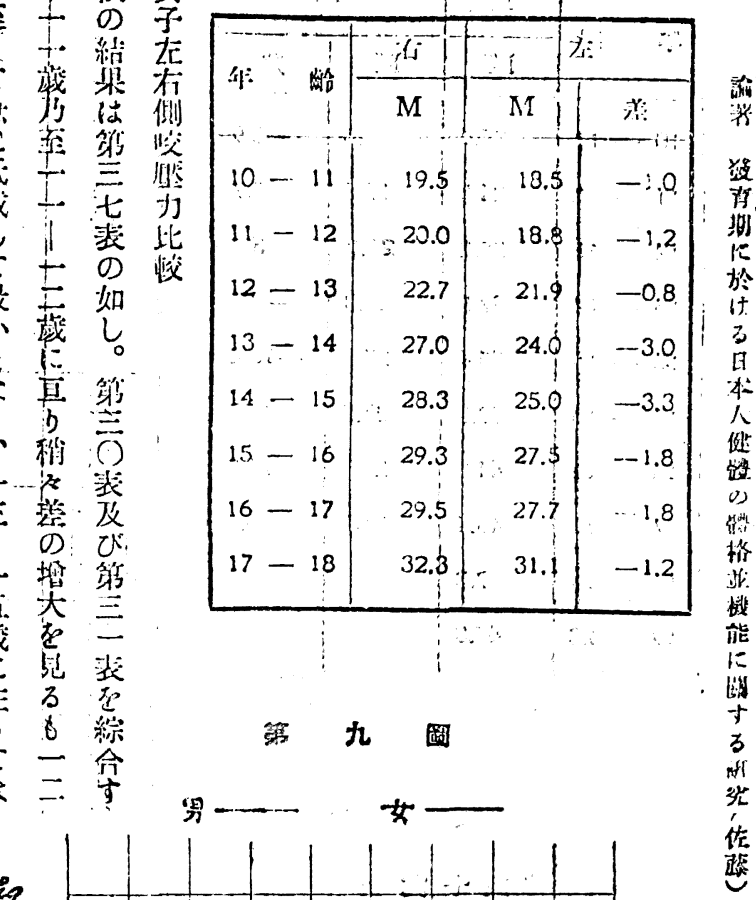

第三十七表:

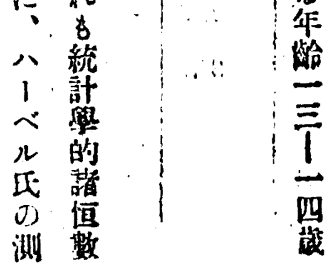

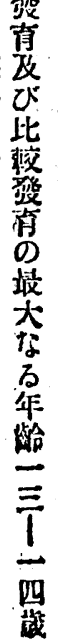


IV 199

第三十八表

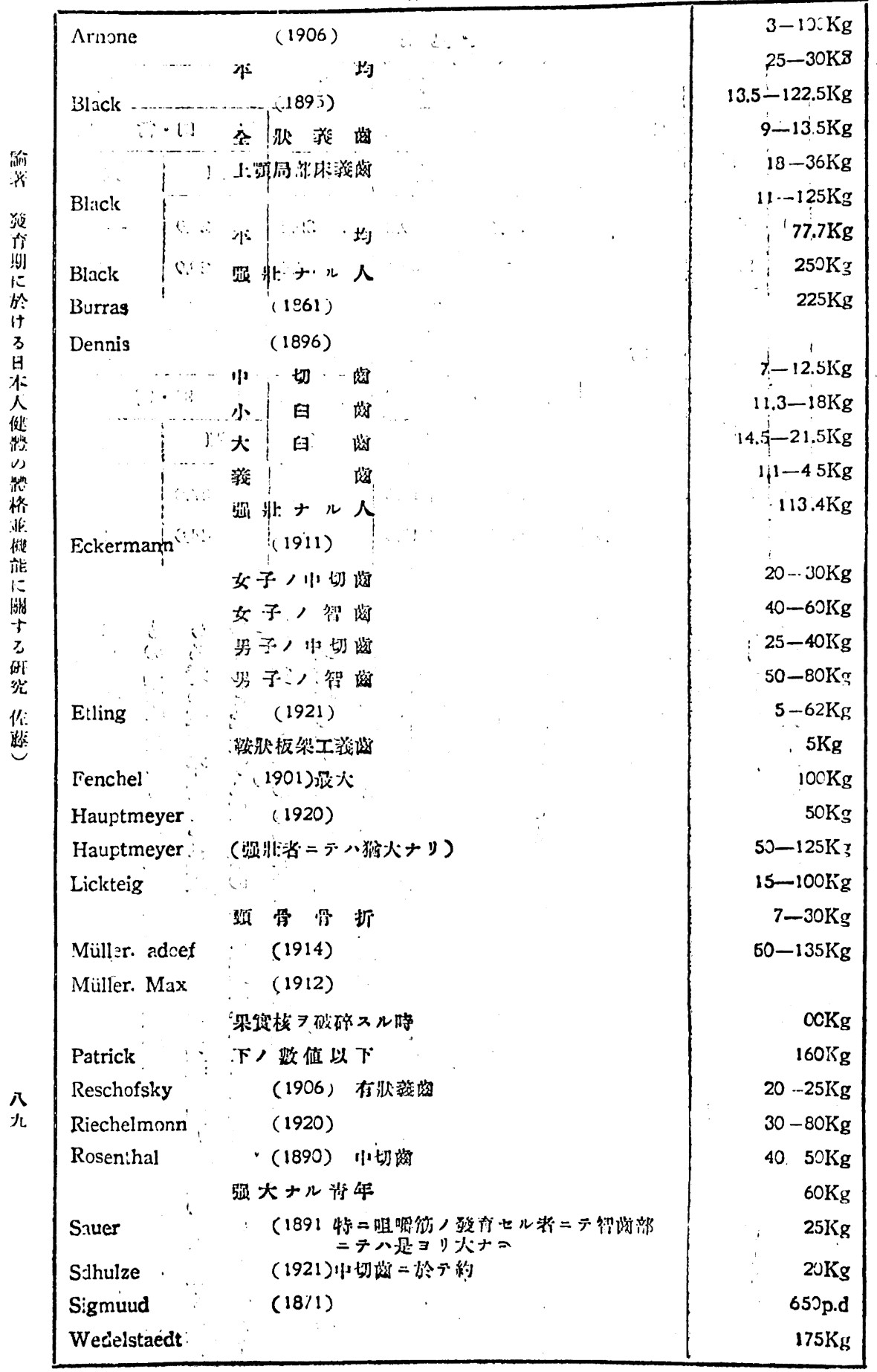




\begin{tabular}{|c|c|c|c|c|c|c|c|c|c|}
\hline \multicolumn{3}{|c|}{$\therefore \therefore r i$} & \multicolumn{7}{|c|}{ 第三十九表 } \\
\hline \multirow{3}{*}{ 筑 } & \multirow{3}{*}{$\because 1$} & \multirow{3}{*}{ i..年 } & \multicolumn{2}{|l|}{ 右 } & \multicolumn{2}{|r|}{ 侧 } & \multicolumn{2}{|l|}{ 左 } & 徏 \\
\hline & & & 佐. I & 网 & 同・箁 & 取 & 俈表 & 网 & 取 \\
\hline & & & 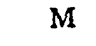 & M & & 溌 & M & $\mathrm{M}$ & 非 \\
\hline 嗮 & .1 & $14-15$ & 39 & 33 & $.6 !$ & -9.3 & 35. & 23.9 & -14.5 \\
\hline W & $\therefore 2$ & $14-15$ & 39 & 35 & 3.4 & -4.5 & 35 & 20.9 & -14.5 \\
\hline
\end{tabular}

\begin{tabular}{|c|c|c|c|c|c|c|c|c|c|}
\hline \multirow{3}{*}{$\begin{array}{l}\text { 發 } \\
\text { 南 }\end{array}$} & \multirow{3}{*}{ 群 } & \multirow[b]{3}{*}{ 蛒 } & \multicolumn{2}{|l|}{ 右 } & \multicolumn{2}{|r|}{ 侧 } & \multicolumn{2}{|l|}{ 左 } & 恻 \\
\hline & & & 位 & 阙 & $\mathrm{m} \cdot \mathrm{m}$ & 取 & 伀 & {$[\mathrm{mi}]$} & 仮 \\
\hline & & & $\mathbf{M}$ & M & & 狽: & M & $\therefore \mathrm{M}$ & 尝: \\
\hline 初: & 1 & $14-15$ & 39.9 & 58.5 & & +18.6 & 35.4 & 37.0 & +1.6 \\
\hline 照 & 2 & $14-15$ & 39.9 & 55.4 & & +15.5 & 35.4 & 44.0 & +8.6 \\
\hline
\end{tabular}

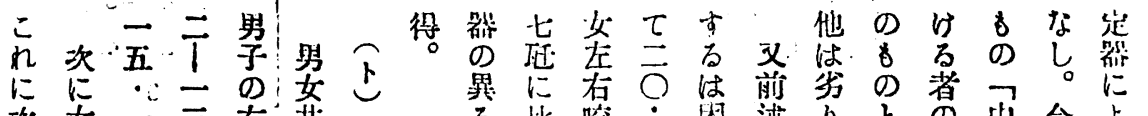

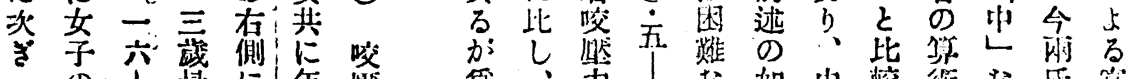

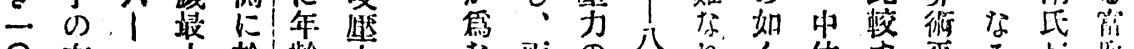

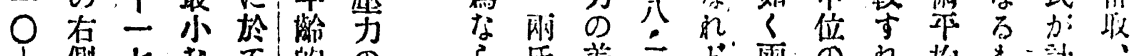

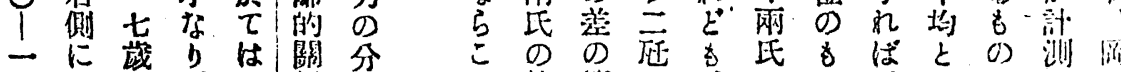

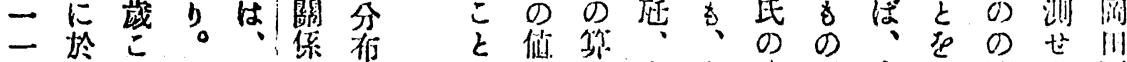

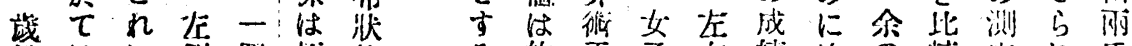

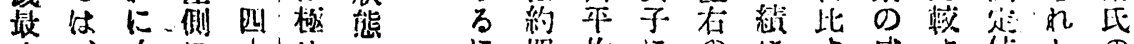
小 $\because$ 次に如均に0

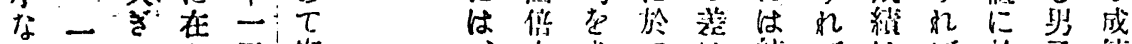

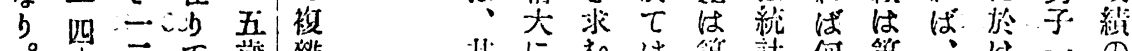

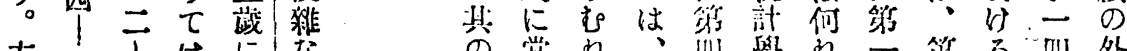

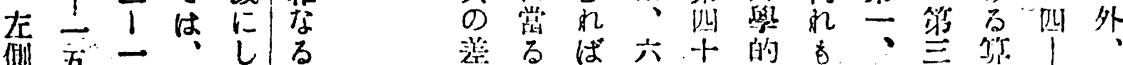

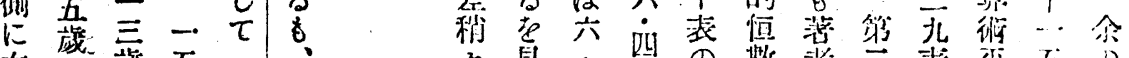

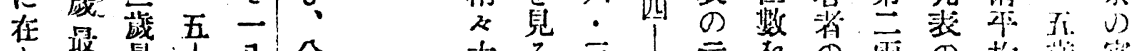

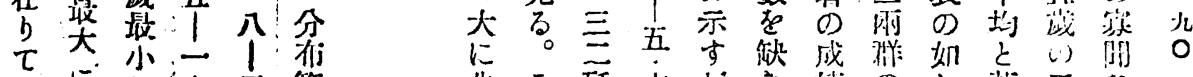

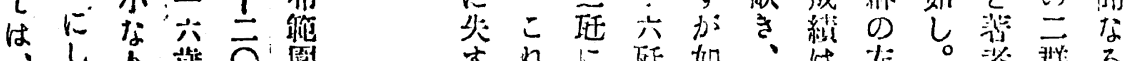

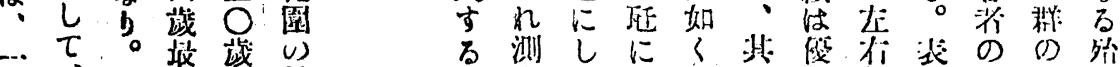

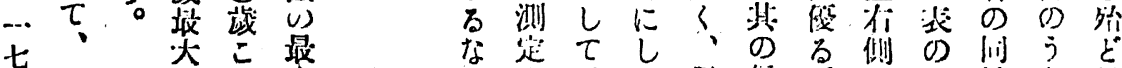

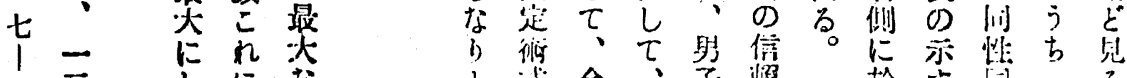

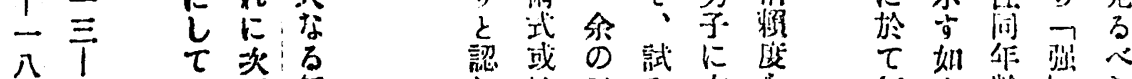

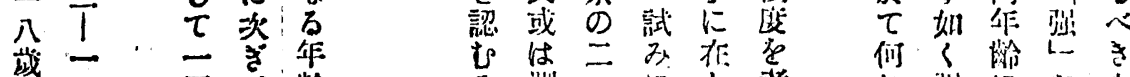

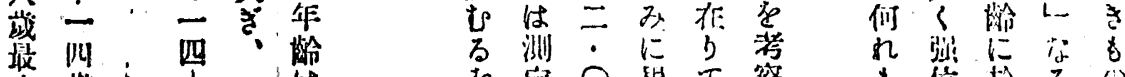

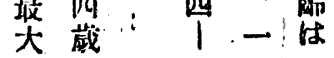

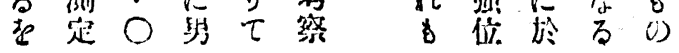


第 四 + 十 表

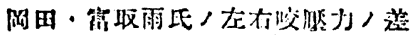

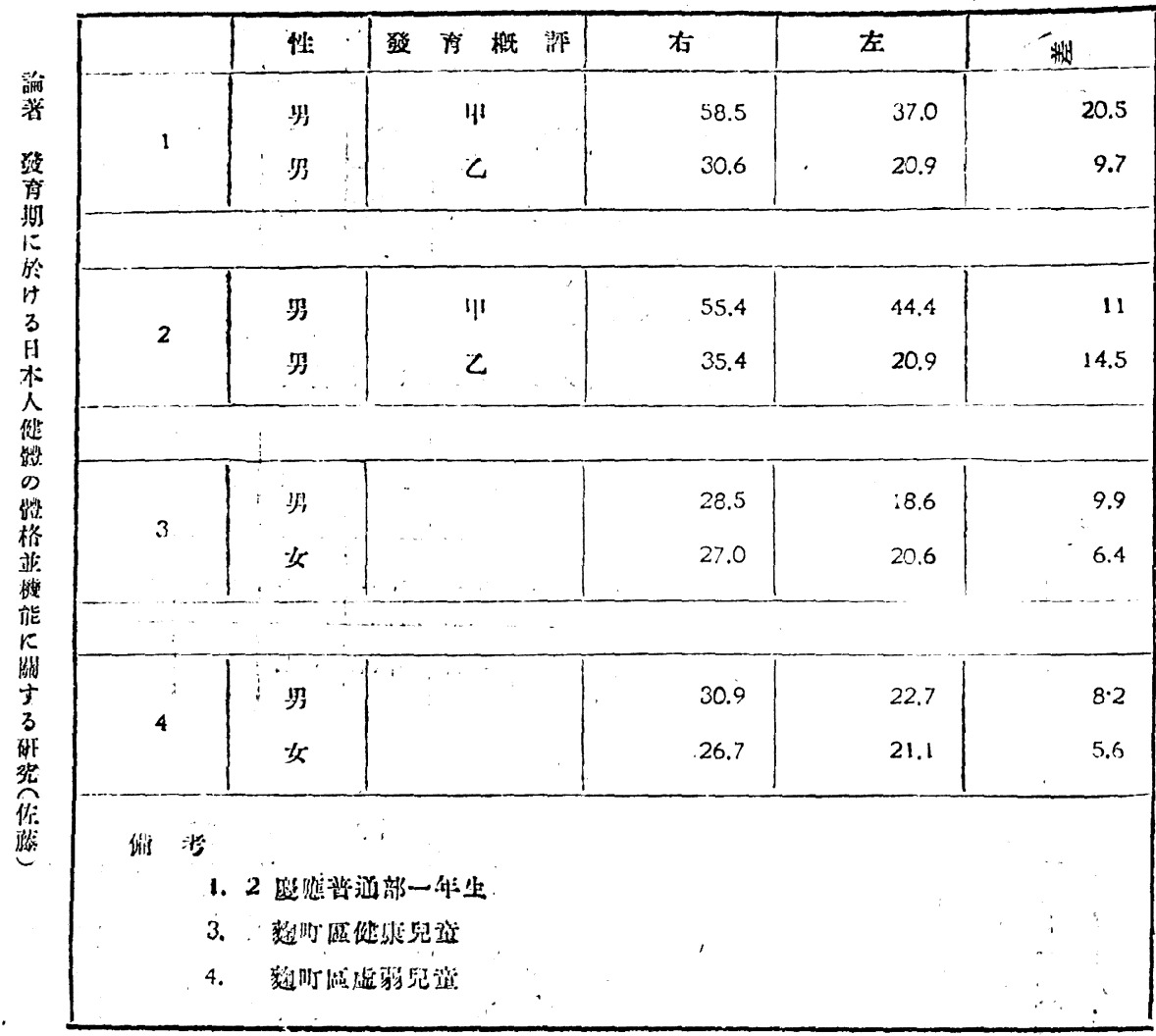

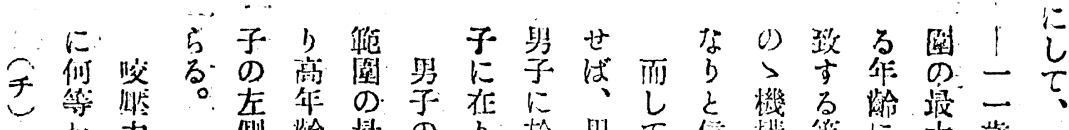

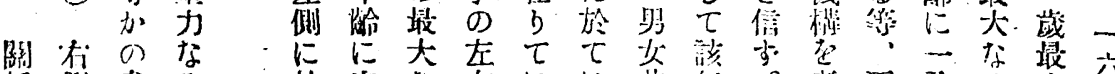

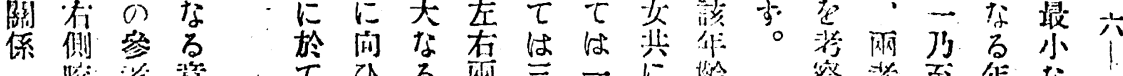

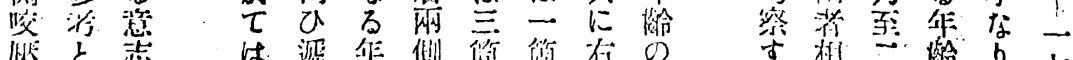

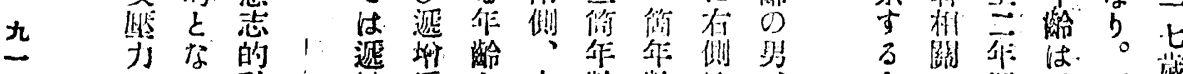

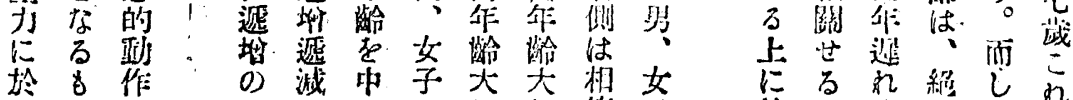

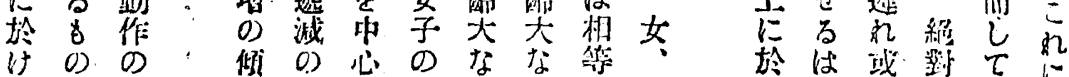

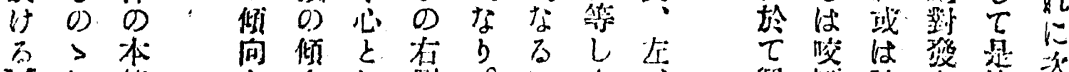

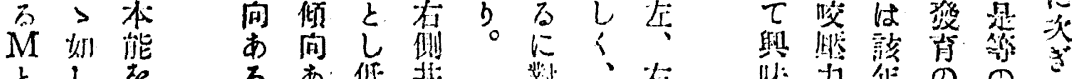

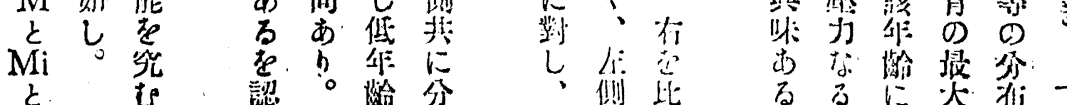

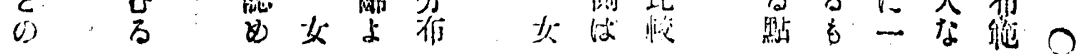




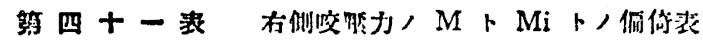

\begin{tabular}{|c|c|c|c|c|c|c|c|c|c|c|}
\hline 性: & $10-11$ & $\mid 11-12$ & $12-13$ & $13-14$ & $14-15$ & $15-6$ & $\mid 16-17\}$ & $17-18$ & $818 T^{-19}$ & $19-20$ \\
\hline $\begin{array}{l}\because 5 \\
\quad \text { In } \\
\end{array}$ & {$\left[\begin{array}{l}+18 \\
\end{array}\right.$} & +2.7 & +0.2 & +3.0 & -0.1 & +1.7 & +0.8 & +0.4 & +0.7 & +2.7 \\
\hline 女 & +0.5 & 0 & +1.7 & +2.0 & +0.3 & -0.7 & -0.5 & +2.0 & - & - \\
\hline (俈) & $\begin{array}{l}+M \\
-M \\
\text { 第四 }+\end{array}$ & $\begin{array}{l}\text { ガ } \mathrm{Mi} \\
\text { カj } \mathrm{Mi} \\
==\text { 表 }\end{array}$ & 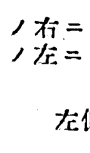 & 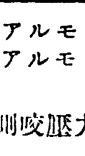 & $\begin{array}{l}\text { ') } \\
\text {, } M\end{array}$ & $1 . M i$ & ）卜人儒 & 偷倚㸚 & & \\
\hline 性 & $\mid 10-11$ & $11-12$ & $12-13$ & 14 & $14-15$ & $15-16$ & $|16-17|$ & $17-18$ & $18-19$ & $19-20$ \\
\hline 39 & +2.4 & +1.5 & +0.2 & +2.5 & +1.4 & +1.2 & +1.0 & +1.9 & -0.7 & -0.2 \\
\hline 女 & +0.5 & +0.8 & +1.9 & +1.0 & 0 & -0.5 & +0.7 & +1.1 & & \\
\hline
\end{tabular}

男絶子最對

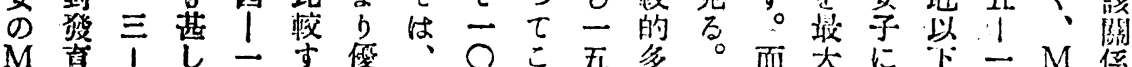

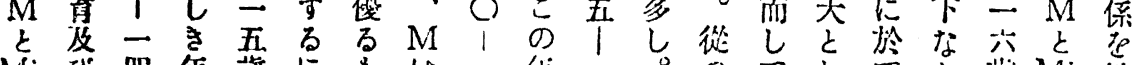
$\mathrm{Mi}$ ひ 叫年藏に过

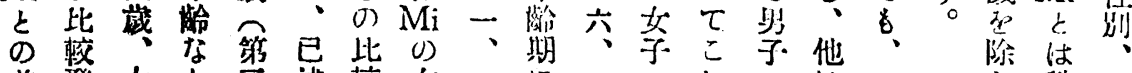

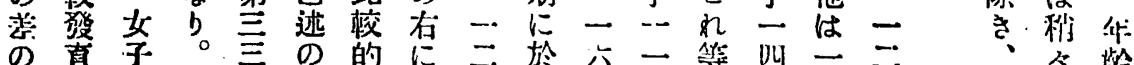

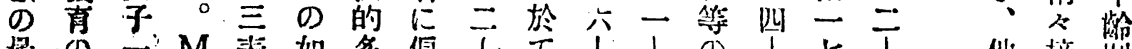

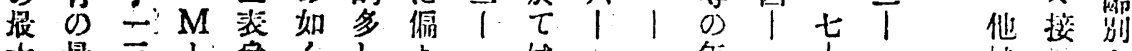

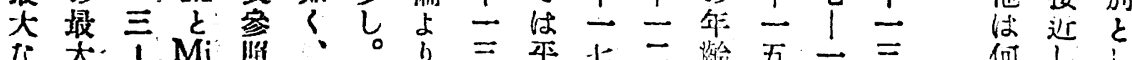

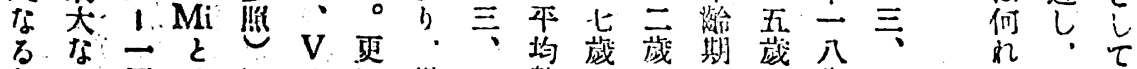

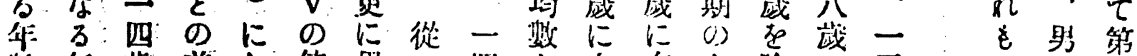

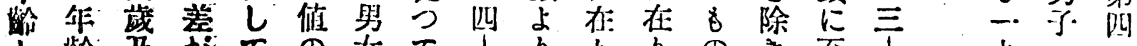
上 䍅 及

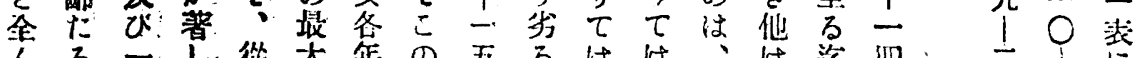

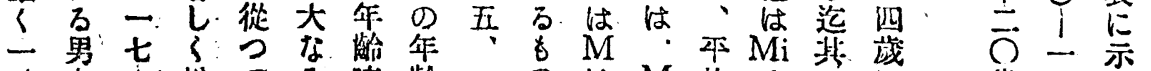

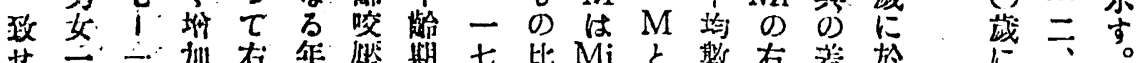

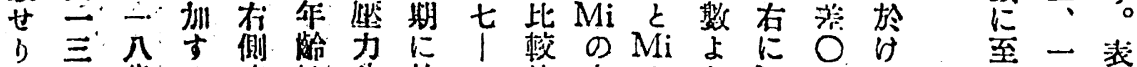

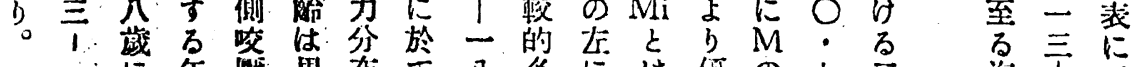

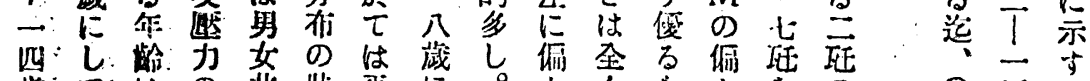

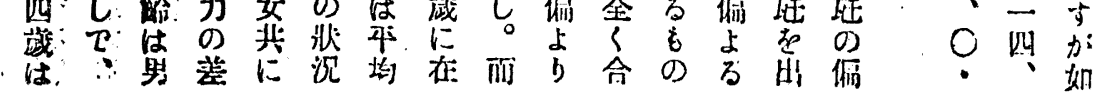
歏。

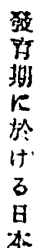
人 紫 格 森 榴 昰 3 DF 究 㢡 


\section{IV运 203}

に数に

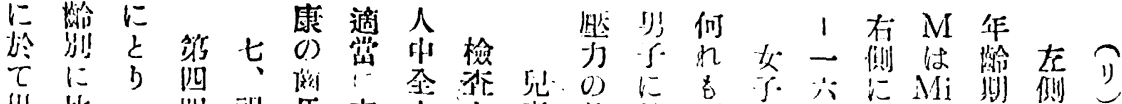

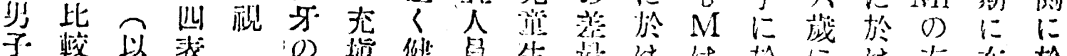

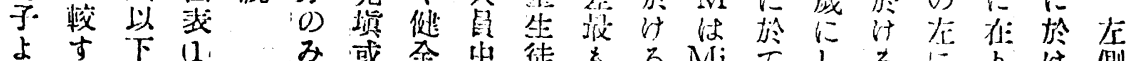

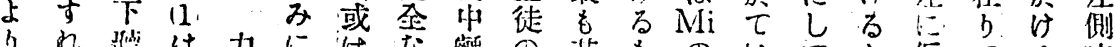

諭小仗少

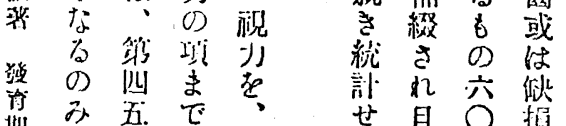

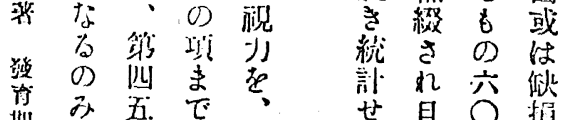

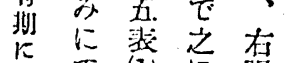

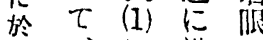

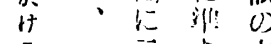

㝵 $\overrightarrow{0}$ 示

本! 加郎初任

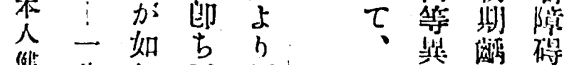

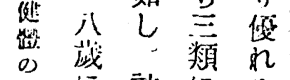

势䍀にる

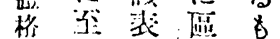

悲吕の分 の

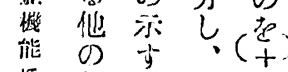

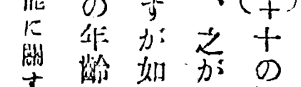

す 船

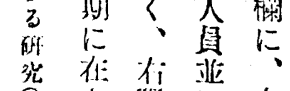

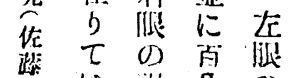

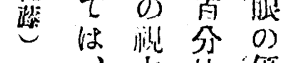

少比 倡

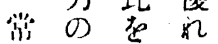

篮部

子

b 0 万

大文 の

な宁な相

b 00 百 $b_{0}$

耐蚠こ灰

七比礼有

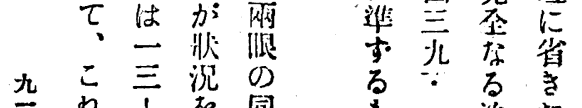

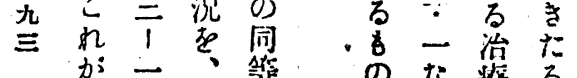

此罗梠 のな症る

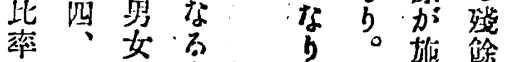

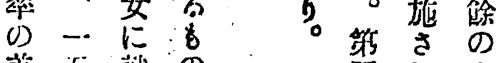

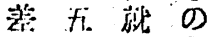

贸 1 它 $(0$,

六齐冬

的藏作橍
第常触坆

斯浔

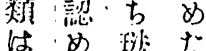

弪 さ㴫る

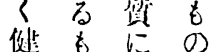

全の煺

西印せ。

の

唯能 し 能

数熊店范

は海整

监恢 仙 理

に世所除

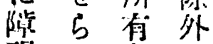

な碍者者筑

侹所流兰

斯 完 触の

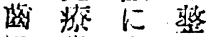

に落完理

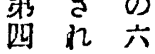

获而六

水而六

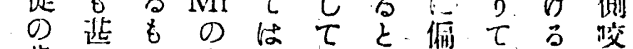

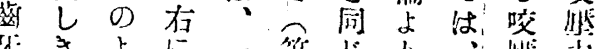

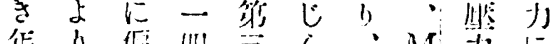

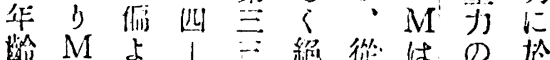

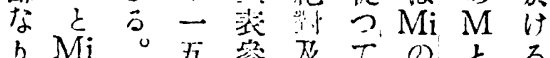

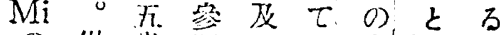

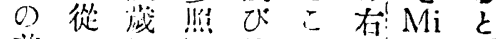

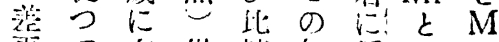

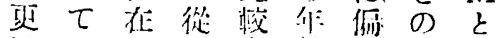

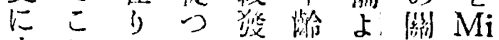
小股 $\tau \tau$ 动划 $b$ 係の

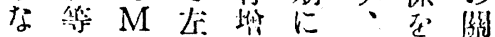
万のと僋扠於從性係 据 $\mathrm{Mi}$ 咬

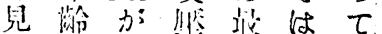

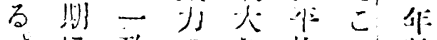

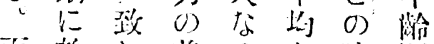

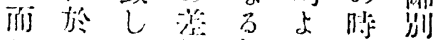

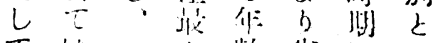

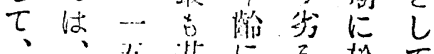

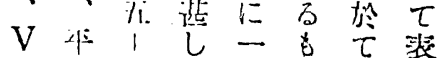

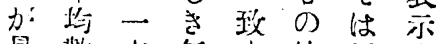
最装六尔古此平卞

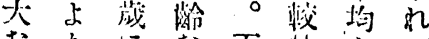

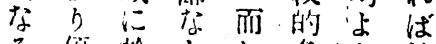

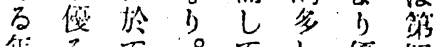

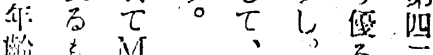

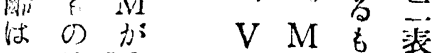

二 比 Mi O $\mathrm{M}$ の

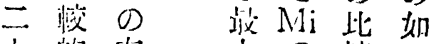

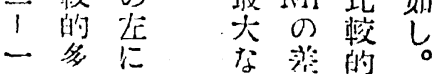

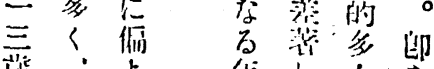

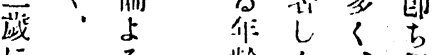

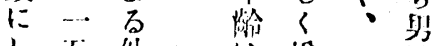

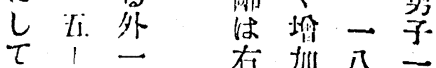

--0 侧古分

第六 ! 少石-

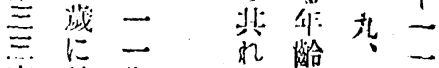

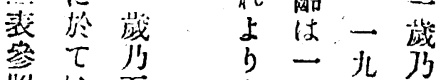

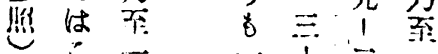

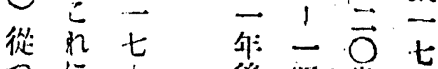

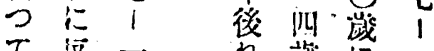

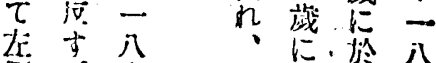

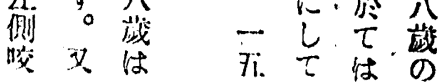


第四 + 三表

\begin{tabular}{|c|c|c|c|c|c|c|c|c|c|c|c|c|c|c|}
\hline 怆: & \multicolumn{2}{|c|}{4 暗 } & 11 & 12 & 13 & 14 & 15 & 16 & 17 & 18 & 19 & 20 & 1 & 㔯 \\
\hline \multirow{3}{*}{ 罗 } & \multicolumn{2}{|c|}{ 蓝查人唄 } & 228 & 383 & 235 & 258 & 357 & 355 & 353 & 310 & 188 & 173 & 2841 & - \\
\hline & \multirow{2}{*}{ 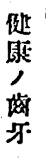 } & 第一斯 & 89 & 199 & 115 & \multicolumn{2}{|c|}{$7 \quad 149$} & 241 & 239 & 223 & 138 & 140 & 1630 & 57.37 \\
\hline & & 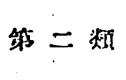 & 139 & 184 & 121 & $161^{i}$ & 208 & 114 & 114 & 87 & 50 & 33 & 1211 & 42,60 \\
\hline \multirow{3}{*}{-女 } & \multicolumn{2}{|c|}{ 输䄳人证 } & 227 & $390^{\prime}$ & 446 & 773 & 750 & 589 & 38: & 219 & \multicolumn{2}{|l|}{. } & 3770 & - \\
\hline & \multirow{2}{*}{ 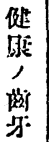 } & 第一頪 & 138 & 235 & 240 & 464 & 450 & 410 & $22^{2}$ & 168 & & & 2397 & $63.5 \mathrm{~s}$ \\
\hline & & 嬥二数 & 89 & 155 & 206 & 309 & 350 & 175 & 88 & 51 & & & $13 \% 3$ & 36.42 \\
\hline
\end{tabular}

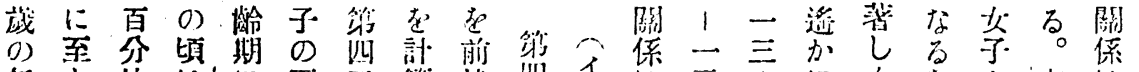

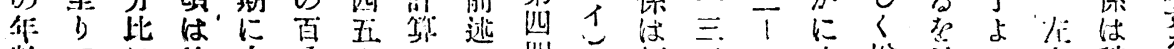

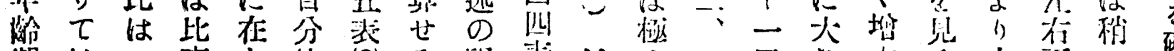

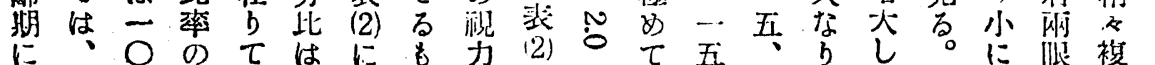

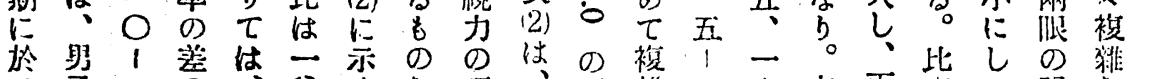

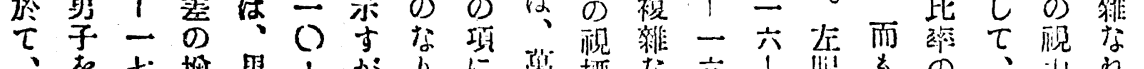

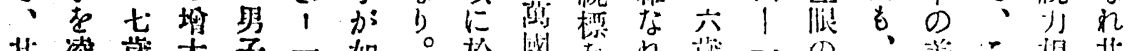

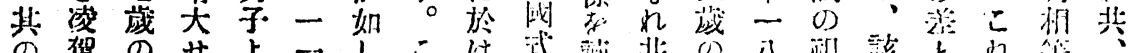

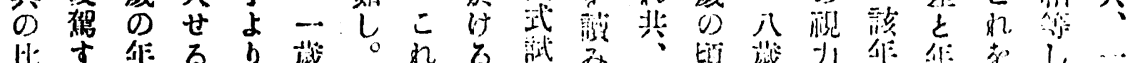

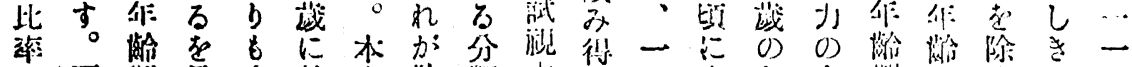

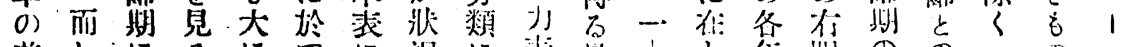

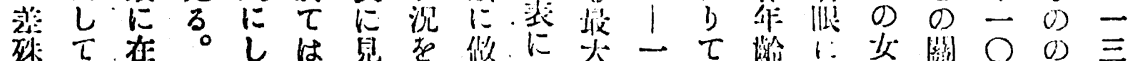

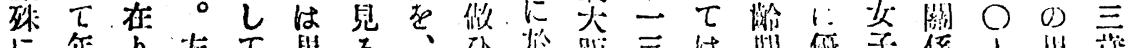

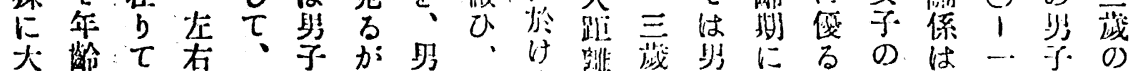

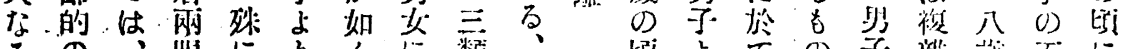

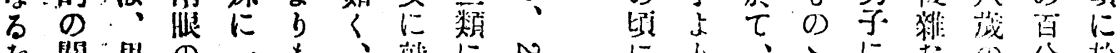

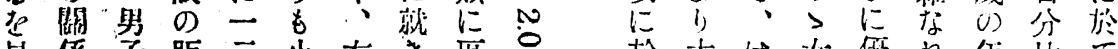

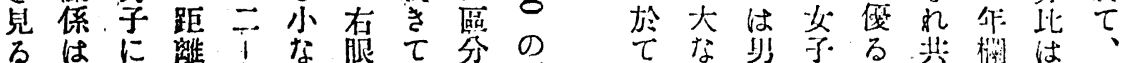

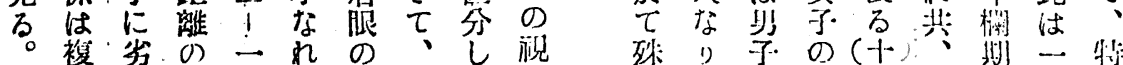

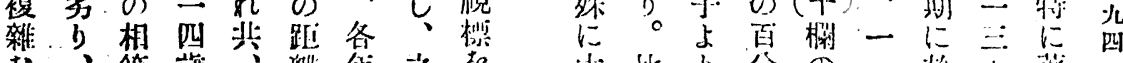

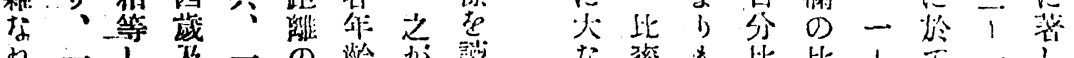

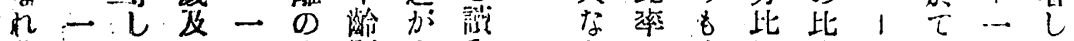

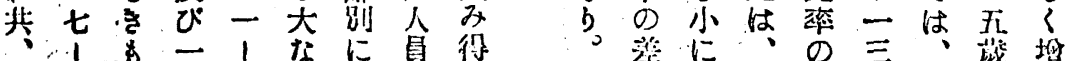

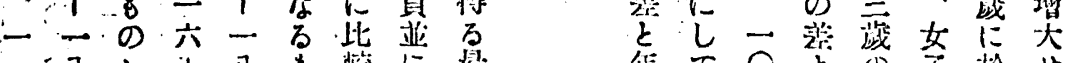

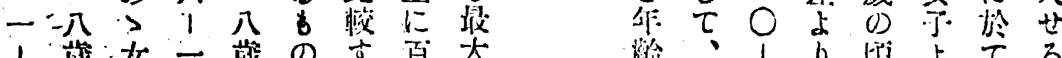

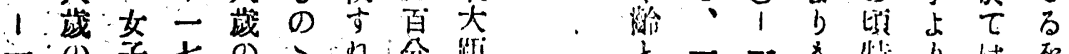

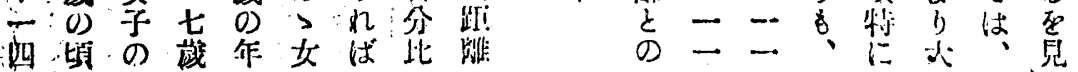




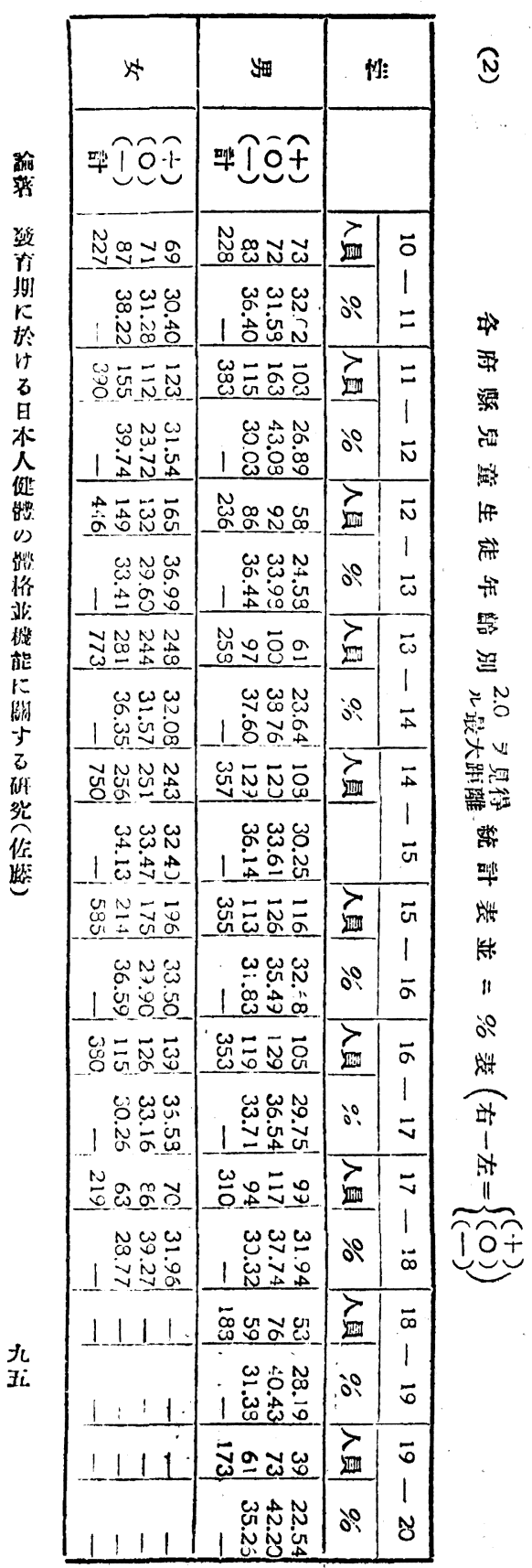

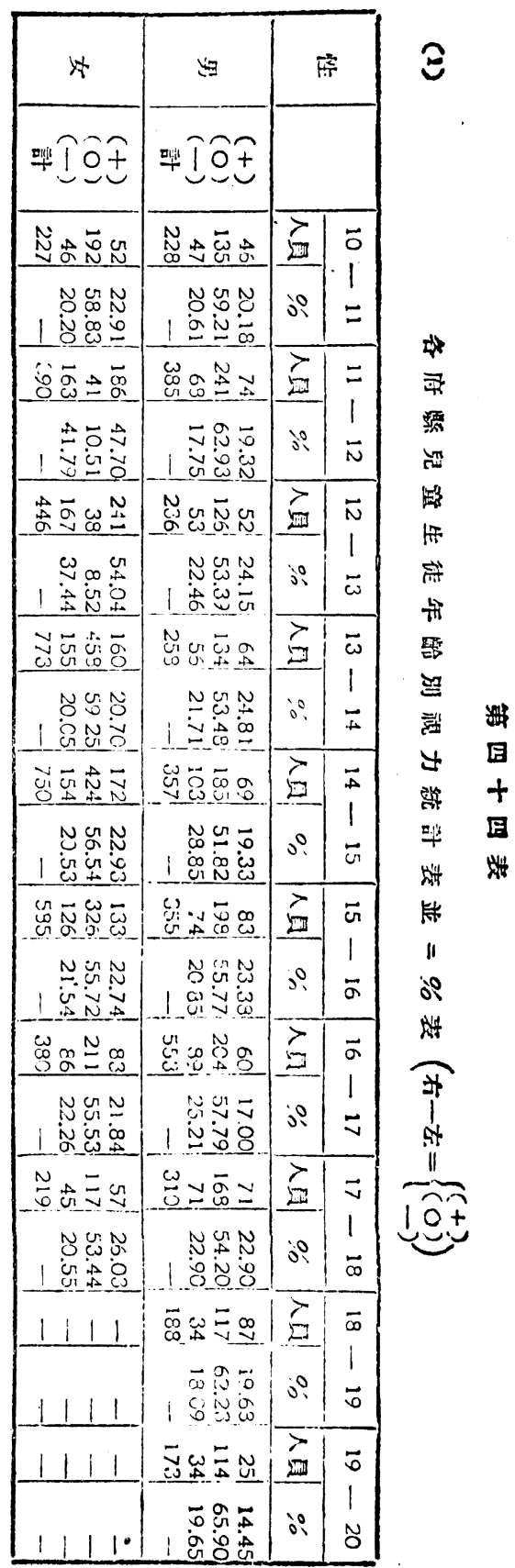


第四十五敖

(1)

(2)

\begin{tabular}{|c|c|c|c|c|c|c|c|c|c|}
\hline \multicolumn{5}{|c|}{ 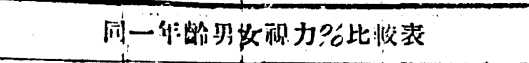 } & \multicolumn{5}{|c|}{ 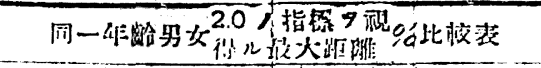 } \\
\hline 年 战 & & 男官 & 女文。 & 溁" & 仯: 紫们 & & $y=j$ & 女星 & 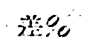 \\
\hline $10-11$ & $\mid \begin{array}{l}+ \\
0 \\
-5\end{array}$ & $\begin{array}{l}2 ? .18 \\
5.21 \\
20.61\end{array}$ & $\begin{array}{l}22.91 \\
56.83 \\
20.26\end{array}$ & $\begin{array}{l}+2.73 \\
-2.33 \\
-0.3 i\end{array}$ & $10-11$ & $\begin{array}{l}(+) \\
0) \\
(-)\end{array}$ & $\begin{array}{l}32.02 \\
3.53 \\
36.40\end{array}$ & $\begin{array}{l}30.40 \\
31.29 \\
38.32\end{array}$ & $\begin{array}{l}-1.62 \\
-0.30 \\
+1.92\end{array}$ \\
\hline $11-12$ & $\begin{array}{l}(+) \\
(0)\end{array}$ & $\begin{array}{l}17.32 \\
62.93 \\
17.75\end{array}$ & $\begin{array}{l}47.70 \\
10.51 \\
41.79\end{array}$ & $\begin{array}{r}-29.84 \\
--52.42 \\
+24.04\end{array}$ & $11-12$ & $\begin{array}{l}(+) \\
(0) \\
(-)\end{array}$ & $\begin{array}{l}26.89 \\
43.08 \\
30.03\end{array}$ & $\begin{array}{l}31: 54 \\
28.72 \\
39.74\end{array}$ & $\begin{array}{r}+4.65 \\
-14.36 \\
+9.71\end{array}$ \\
\hline $\begin{array}{c}1 \\
\vdots \\
\vdots \\
\vdots\end{array}$ & $\begin{array}{l}(+) \\
(0) \\
(-)\end{array}$ & $\begin{array}{l}24.15 \\
53.37 \\
22.46\end{array}$ & $\begin{array}{r}54.04 \\
8.52 \\
37.44\end{array}$ & $\begin{array}{r}+2 \% .87 \\
-14.87 \\
+14.98\end{array}$ & $12-13$ & $\begin{array}{l}(+) \\
(0) \\
(-)\end{array}$ & $\begin{array}{l}24,58 \\
33: 98 \\
36,44\end{array}$ & $\begin{array}{l}36.99 \\
29.60 \\
33.41\end{array}$ & $\begin{array}{r}+1241 \\
-9.39 \\
-3.03\end{array}$ \\
\hline $13 \div 14$ & $\begin{array}{l}(+) \\
(0)\end{array}$ & $\begin{array}{l}2481 \\
53.43 \\
2 . .71\end{array}$ & $\begin{array}{l}20.70 \\
59.25 \\
20.25\end{array}$ & $\begin{array}{r}-4.11 \\
+5.77 \\
-1.46\end{array}$ & $13-14$ & $\begin{array}{l}+1) \\
(0)\end{array}$ & $\begin{array}{l}23.64 \\
38.76 \\
37.60\end{array}$ & $\begin{array}{l}32.08 \\
31.57 \\
36.35\end{array}$ & $\begin{array}{l}+8.4 ! \\
-7.19 \\
-1.25\end{array}$ \\
\hline $14-15$ & $\begin{array}{l}(+) \\
(0) \\
(-)\end{array}$ & $\begin{array}{r}19.33 \\
51.32 \\
28.85\end{array}$ & $\begin{array}{l}22.93 \\
56.54 \\
20.53\end{array}$ & $\begin{array}{l}+3.60 \\
+4.72 \\
-8.32\end{array}$ & $14-15$ & $\begin{array}{l}(+) \\
(0) \\
(-)\end{array}$ & $\begin{array}{l}30.25 \\
33,61 \\
36,14\end{array}$ & $\begin{array}{l}32.40 \\
33.47 \\
34.13\end{array}$ & $\begin{array}{l}+2.15 \\
-0.14 \\
-2.01\end{array}$ \\
\hline $15-16$ & $\begin{array}{l}(+) \\
(0) \\
-1\end{array}$ & $\begin{array}{l}23.39 \\
55.77 \\
20.85\end{array}$ & $\begin{array}{l}22.74 \\
55.72 \\
21.54\end{array}$ & $\begin{array}{l}-0.64 \\
-0.55 \\
+0.69\end{array}$ & $15-16$ & $\begin{array}{l}(+) \\
(0) \\
(-)\end{array}$ & $\begin{array}{l}32.63 \\
35.49 \\
31.38 \\
\vdots\end{array}$ & $\begin{array}{l}3.50 \\
27.91 \\
36.59\end{array}$ & $\begin{array}{r}+0.83 \\
-5.59 \\
+4.76\end{array}$ \\
\hline $\begin{array}{c}16-17 \\
\vdots\end{array}$ & $\begin{array}{l}6+ \\
6\end{array}$ & $\begin{array}{l}17.00 \\
57.79 \\
25.21\end{array}$ & $\begin{array}{l}21.84 \\
55.53 \\
22.63\end{array}$ & $\begin{array}{l}+4.84 \\
-2.20 \\
-2.53\end{array}$ & $16-17$ & $\begin{array}{l}(+) \\
(0)\end{array}$ & $\begin{array}{l}29.75 \\
36.54 \\
33,71\end{array}$ & $\begin{array}{l}36.58 \\
3.3 .16 \\
30.26\end{array}$ & $\begin{array}{l}+6.33 \\
-3.38 \\
-3.45\end{array}$ \\
\hline $17: 18$ & $\left(\begin{array}{l}+t) \\
(0) \\
-\end{array}\right)$ & $\begin{array}{l}22.90 \\
54.20 \\
22.90\end{array}$ & $\begin{array}{l}26.03 \\
53.42 \\
20.55\end{array}$ & $\begin{array}{l}+3.13 \\
-0.78 \\
-2.33\end{array}$ & $17 .-13$ & $\begin{array}{l}(+) \\
0) \\
(-)\end{array}$ & $\begin{array}{l:c}31: & 4 \\
37,7 & \\
30 & 32\end{array}$ & $\begin{array}{l}31.96 \\
39.27 \\
33.77\end{array}$ & $\begin{array}{l}+0.02 \\
+1.53 \\
-1.55\end{array}$ \\
\hline $18-19$ & $\begin{array}{l}(+) \\
(0) \\
(-)\end{array}$ & $\begin{array}{l}19.63 \\
62.23 \\
18.09\end{array}$ & - & $\begin{array}{l}\cdots \\
\cdots- \\
\cdots-\end{array}$ & $18--19$ & $\begin{array}{l}(+) \\
(0) \\
(-)\end{array}$ & $\begin{array}{l}28.19 \\
40.43 \\
31.39\end{array}$ & - & - \\
\hline$(9--2)$ & $\begin{array}{l}(+) \\
(0) \\
(-)\end{array}$ & $\begin{array}{l}14.45 \\
65.90 \\
19.65\end{array}$ & $\begin{array}{l}- \\
-\end{array}$ & $\overline{-}$ & $19-20$ & $\begin{array}{l}(+) \\
(0) \\
(-)\end{array}$ & $\begin{array}{l}22.54 \\
4 ? .20 \\
3526\end{array}$ & $\begin{array}{l}- \\
-\end{array}$ & - \\
\hline
\end{tabular}

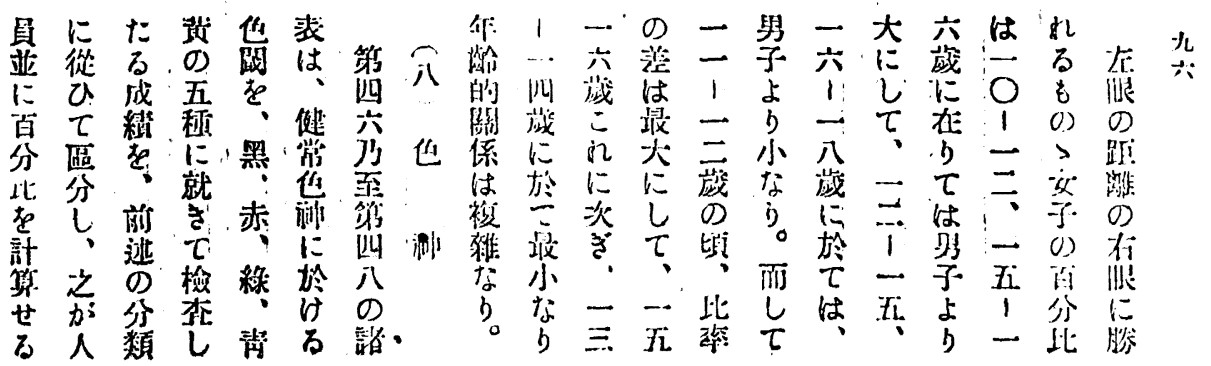




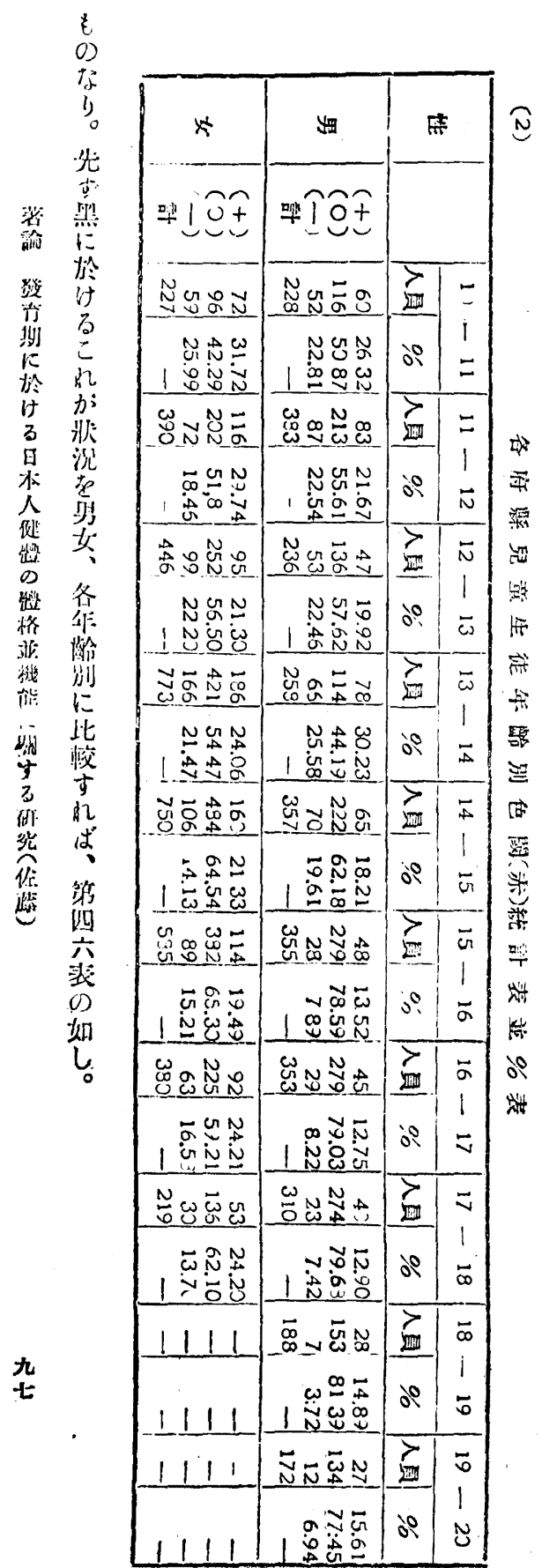

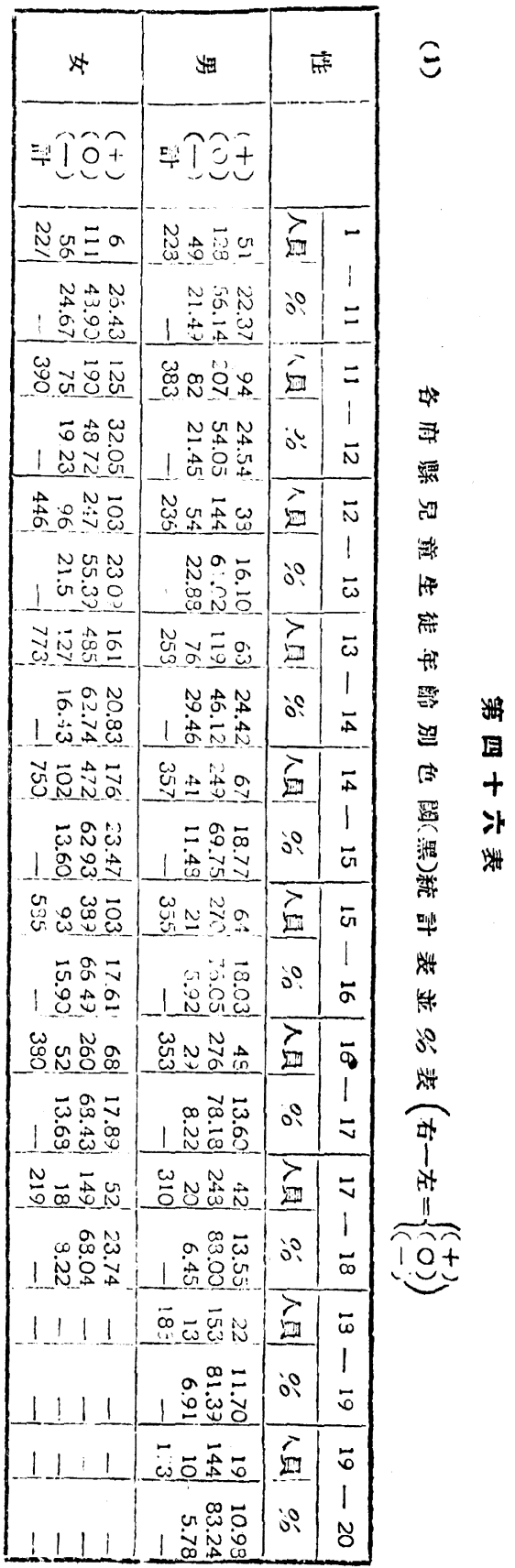




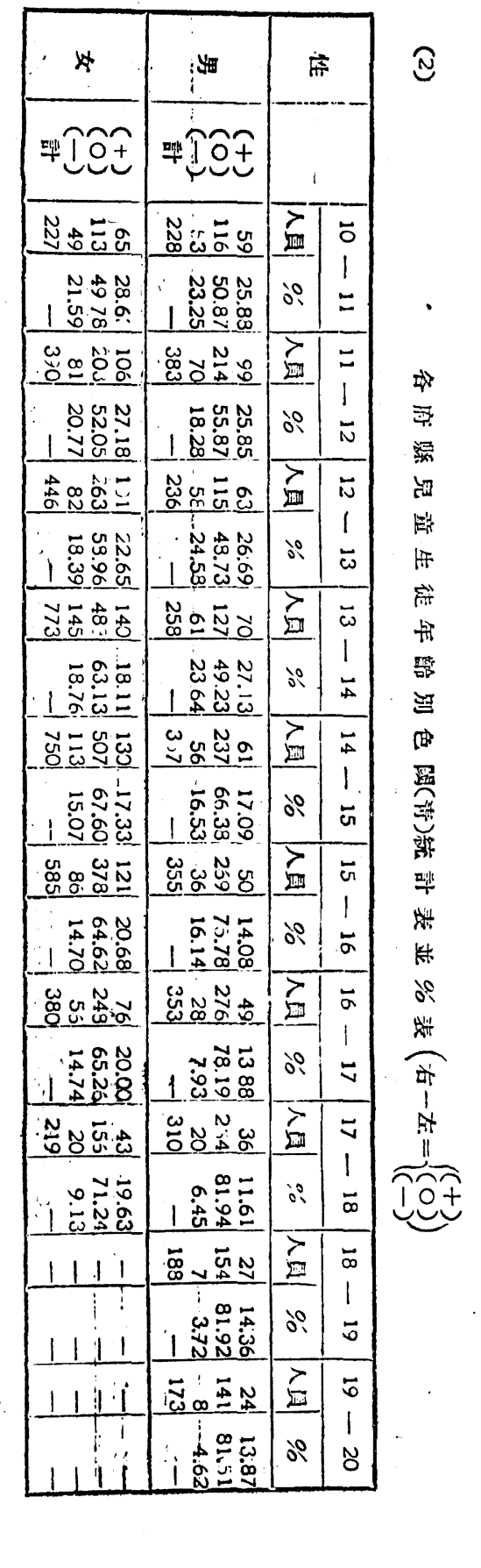

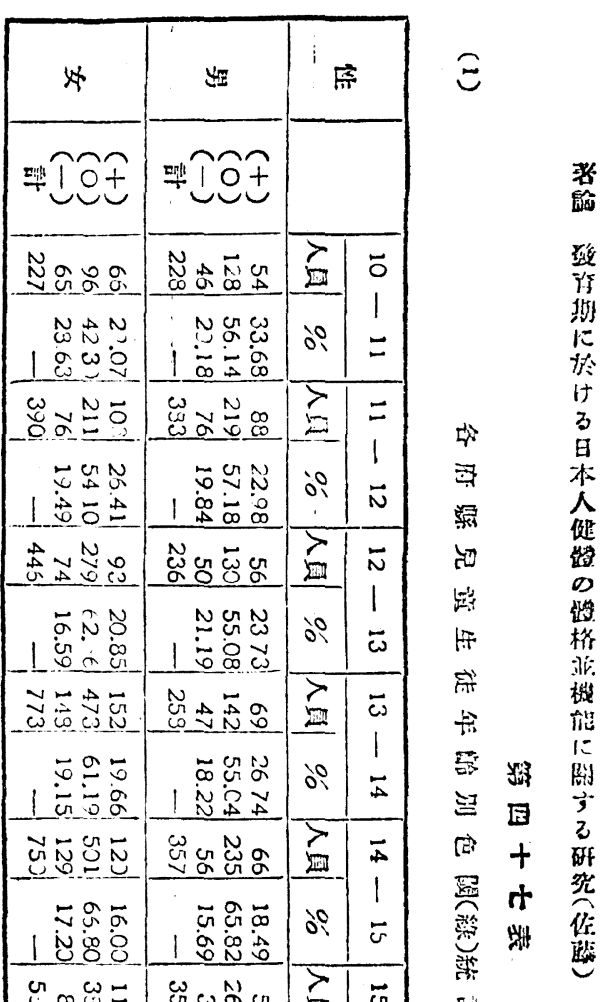




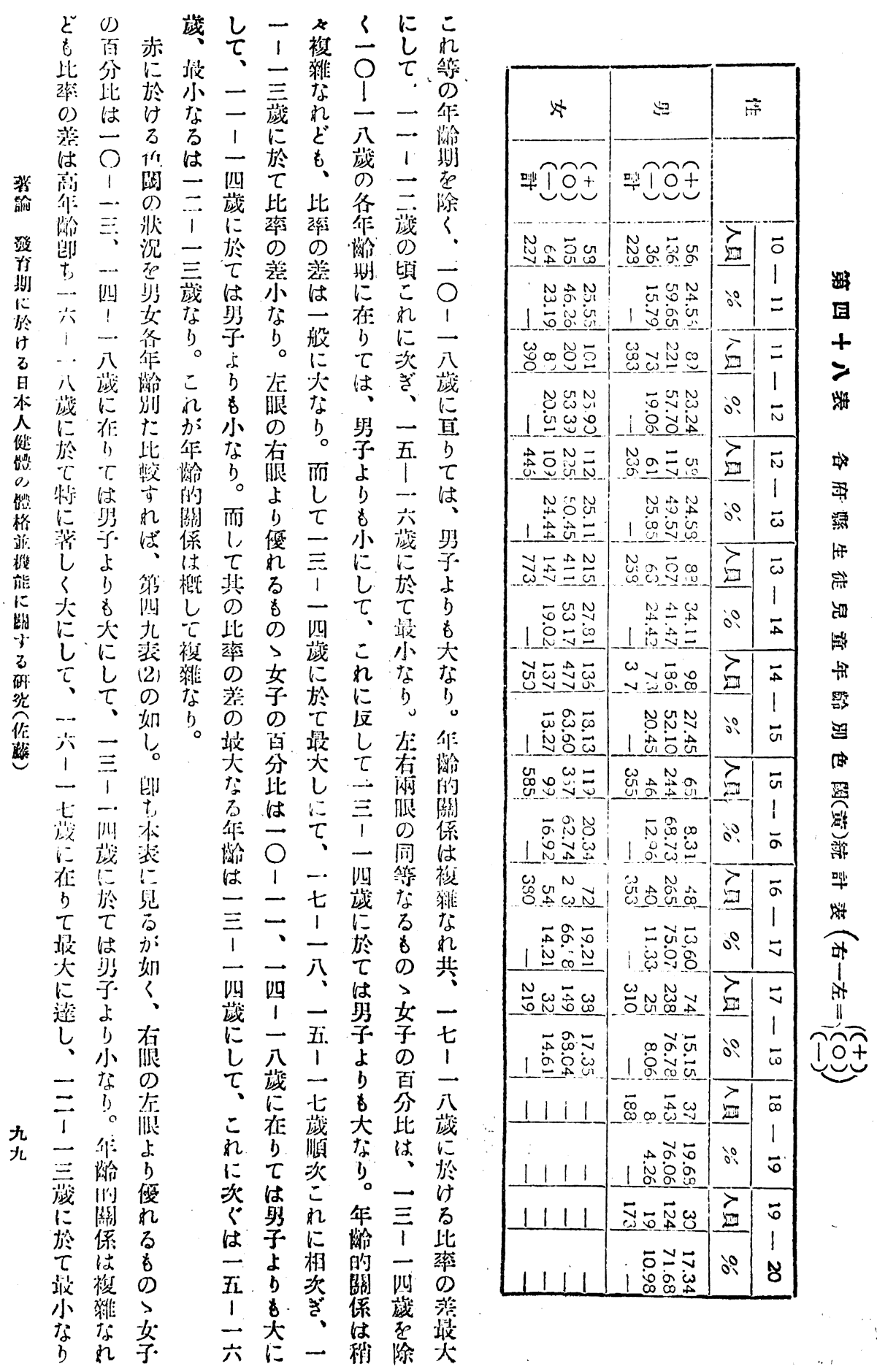


嗼四十九表

(1)

(2)

\begin{tabular}{|c|c|c|c|c|c|c|c|c|c|}
\hline \multicolumn{5}{|c|}{ 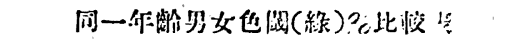 } & \multicolumn{5}{|c|}{ 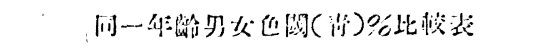 } \\
\hline 告部 & & 男\% & 女? & 谈 & 年 夦 & & 少 & 女娄。 & 为奖 \\
\hline $10-11$ & $\begin{array}{l}\text { (+ } \\
\text { (0 }\end{array}$ & $\begin{array}{l}22.39 \\
56.14 \\
21.49\end{array}$ & $\begin{array}{l}26.3 \\
48.90 \\
24.67\end{array}$ & $\begin{array}{l}+4.04 \\
-7.24 \\
+3.18\end{array}$ & $10-\cdots 11$ & $\begin{array}{l}c^{+} \\
(-\end{array}$ & $\begin{array}{l}25.32 \\
50.87 \\
22.81\end{array}$ & $\begin{array}{l}31.72 \\
42.29 \\
25.99\end{array}$ & $\begin{array}{r}+5.40 \\
-\because .8 \\
+3.18\end{array}$ \\
\hline $11-12$ & $(c)$ & $\begin{array}{l}24.54 \\
54.05 \\
21.41\end{array}$ & $\begin{array}{l}3: 05 \\
48: i 2 \\
19.23\end{array}$ & $\begin{array}{r}+7.51 \\
-.33 \\
-2.13\end{array}$ & $11-12$ & & $\begin{array}{l}21.67 \\
55.51 \\
22.54\end{array}$ & $\begin{array}{l}29.74 \\
51.0 \\
18.46\end{array}$ & $\begin{array}{l}+8.07 \\
-3.81 \\
-4.03\end{array}$ \\
\hline $12-13$ & $\begin{array}{l}(-1 \\
(0\end{array}$ & $\begin{array}{l}16.10 \\
61.02 \\
22.83\end{array}$ & $\begin{array}{l}23.09 \\
55.39 \\
21.52\end{array}$ & $\begin{array}{r}-1.6 .99 \\
-5.63 \\
-1.36\end{array}$ & $12-13$ & & $\begin{array}{l}19.92 \\
57.62 \\
22.46\end{array}$ & $\begin{array}{l}21.30 \\
56.50 \\
22.20\end{array}$ & $\begin{array}{r}-1.33 \\
-1.12 \\
-0.25\end{array}$ \\
\hline $13-14$ & $\begin{array}{l}c_{0}^{+} \\
\text {co }\end{array}$ & $\begin{array}{l}2.4 .42 \\
16.12 \\
29.46\end{array}$ & $\begin{array}{l}20.83 \\
62.74 \\
16.43\end{array}$ & $\begin{array}{r}-3.59 \\
+16.62 \\
-13.03\end{array}$ & $13-14$ & $\begin{array}{l}(+) \\
(0) \\
(-)\end{array}$ & $\begin{array}{l}=0.23 \\
44.19 \\
25.58\end{array}$ & $\begin{array}{l}24.06 \\
54.47 \\
21.47\end{array}$ & $\begin{array}{r}-6.17 \\
+10.28 \\
-4.1 !\end{array}$ \\
\hline $14-15$ & (c) & $\begin{array}{l}18.77 \\
69.75 \\
11.48\end{array}$ & $\begin{array}{l}23.47 \\
62.93 \\
13.60\end{array}$ & $\begin{array}{l}+4.70 \\
-6.82 \\
-2.12\end{array}$ & $14 \mid 15$ & & $\begin{array}{l}13.21 \\
62.15 \\
19.61\end{array}$ & $\begin{array}{l}31.33 \\
64.54 \\
14.13\end{array}$ & $\begin{array}{r}+3.12 \\
+2.36 \\
-5.49\end{array}$ \\
\hline $15-16$ & (c) & $\begin{array}{r}18.03 \\
76.05 \\
5.92\end{array}$ & $\begin{array}{l}17.61 \\
64.49 \\
15.90\end{array}$ & $\begin{array}{r}-0.42 \\
-9.56 \\
+9.93\end{array}$ & $15-16$ & $\begin{array}{l}(+-) \\
(0) \\
(-)\end{array}$ & $\begin{array}{r}13.52 \\
78.59 \\
7.89\end{array}$ & $\begin{array}{l}19.49 \\
65.30 \\
15.21\end{array}$ & $\begin{array}{r}-1.5 .97 \\
-13.27 \\
+7.32\end{array}$ \\
\hline $16-17$ & $\begin{array}{l}(+) \\
(0) \\
(-)\end{array}$ & $\begin{array}{r}13.60 \\
78.18 \\
8.22\end{array}$ & $\begin{array}{l}17.89 \\
68.43 \\
1363\end{array}$ & $\begin{array}{l}+4.29 \\
-9.15 \\
+5.46\end{array}$ & $16-17$ & & $\begin{array}{r}12.75 \\
79.03 \\
8.22\end{array}$ & $\begin{array}{l}24.21 \\
59.21 \\
16.58\end{array}$ & $\begin{array}{r}+11.46 \\
-19.82 \\
+8.36\end{array}$ \\
\hline $17-18$ & $\begin{array}{l}(+) \\
(0) \\
(-)\end{array}$ & $\begin{array}{r}13.55 \\
80,00 \\
6.45\end{array}$ & $\begin{array}{r}23.74 \\
68.04 \\
8.22\end{array}$ & $\begin{array}{r}+10.19 \\
-11.96 \\
+1.77\end{array}$ & $17-18$ & $\begin{array}{l}(+) \\
(0) \\
(-)\end{array}$ & $\begin{array}{r}12.90 \\
79.68 \\
7.42\end{array}$ & $\begin{array}{l}24.20 \\
62.10 \\
13.70\end{array}$ & $\begin{array}{r}+11.30 \\
-17.58 \\
+6.28\end{array}$ \\
\hline $18-19$ & $\begin{array}{l}(+) \\
(0) \\
(-)\end{array}$ & $\begin{array}{r}11.70 \\
61.39 \\
6.91\end{array}$ & - & - & $18-19$ & $\begin{array}{l}(+) \\
(0) \\
(-)\end{array}$ & $\begin{array}{r}14.89 \\
81.33 \\
3.72\end{array}$ & $\overline{-}$ & - \\
\hline $19-20$ & $\begin{array}{l}(+) \\
(0) \\
(-)\end{array}$ & $\begin{array}{r}10.98 \\
83.24 \\
5.78\end{array}$ & - & - & $19-20$ & $\begin{array}{l}(t) \\
(0) \\
(-)\end{array}$ & $\begin{array}{r}15.61 \\
77.45 \\
6.94\end{array}$ & - & - \\
\hline
\end{tabular}

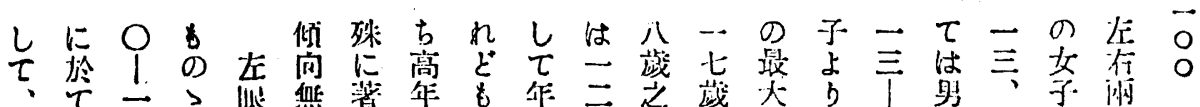

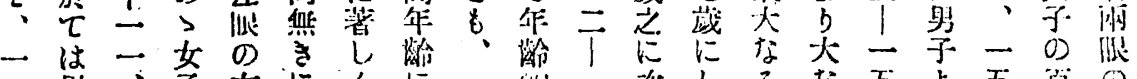

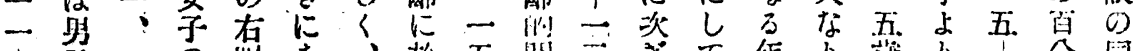

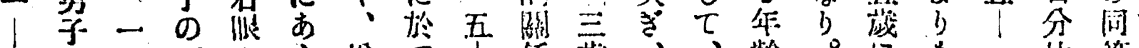

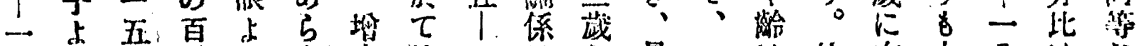

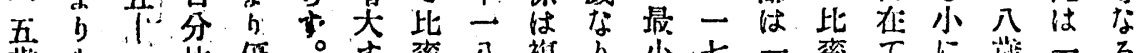

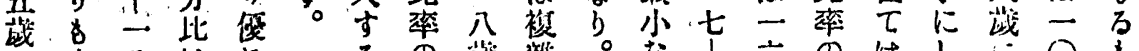

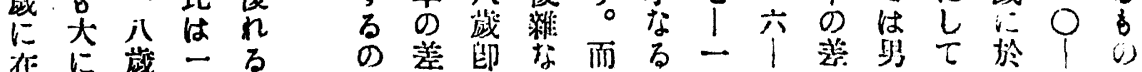


第五十表

(1)

(2)

\begin{tabular}{|c|c|c|c|c|c|c|c|c|c|}
\hline \multicolumn{5}{|c|}{ 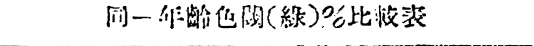 } & \multicolumn{5}{|c|}{ 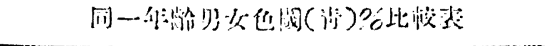 } \\
\hline 作 路 & & 出官 & 女??ó & 非 & 作 蛤 & & 将: & 年: & 新 \\
\hline $10-11$ & $\begin{array}{l}(+1) \\
(0) \\
(-)\end{array}$ & $\begin{array}{l}23.68 \\
56.14 \\
20.18\end{array}$ & $\begin{array}{l}29.07 \\
42.30 \\
28.63\end{array}$ & $\begin{array}{r}+3.39 \\
-13.84 \\
+8.45\end{array}$ & $10--11$ & $\begin{array}{l}(+) \\
(0) \\
(-)\end{array}$ & $\begin{array}{l}25.83 \\
50.87 \\
23.25\end{array}$ & $\begin{array}{l}23.63 \\
49.78 \\
21.59\end{array}$ & $\begin{array}{r}-2.75 \\
-1.09 \\
-1.65\end{array}$ \\
\hline $11-12$ & $\begin{array}{l}(-1) \\
(0) \\
(-)\end{array}$ & $\begin{array}{l}22.98 \\
57.18 \\
19 . \subseteq 4\end{array}$ & $\begin{array}{l}26.41 \\
54.10 \\
19.49\end{array}$ & $\begin{array}{r}+3.43 \\
-3.08 \\
-0.65 \\
\end{array}$ & $11--12$ & $\begin{array}{l}(-\mu) \\
(0) \\
(-)\end{array}$ & $\begin{array}{l}25.85 \\
55.87 \\
18.28\end{array}$ & $\begin{array}{l}27.18 \\
52.05 \\
20.72\end{array}$ & $\begin{array}{r}+-1.33 \\
--3.82 \\
+2.49\end{array}$ \\
\hline $12-13$ & $\begin{array}{l}(-i) \\
(0)\end{array}$ & $\begin{array}{l}23.73 \\
55.08 \\
21.19\end{array}$ & $\begin{array}{l}20.85 \\
62.56 \\
16.59\end{array}$ & $\begin{array}{r}-2.88 \\
+7.43 \\
-4.60\end{array}$ & $12-13$ & $\begin{array}{l}(\cdot i) \\
(0) \\
(\cdot \cdot)\end{array}$ & $\begin{array}{l}25.69 \\
43.73 \\
24.53\end{array}$ & $\begin{array}{l}22.65 \\
53.96 \\
18.39\end{array}$ & $\begin{array}{r}-4.04 \\
+10.23 \\
-6.19\end{array}$ \\
\hline $13-14$ & $\begin{array}{l}(+) \\
(0) \\
(-)\end{array}$ & $\begin{array}{l}26.74 \\
55.04 \\
18.22\end{array}$ & $\begin{array}{l}19.66 \\
61.19 \\
19.15\end{array}$ & $\begin{array}{r}17.08 \\
+6.15 \\
+0.93\end{array}$ & $13-14$ & $\begin{array}{l}(+) \\
(0) \\
(-)\end{array}$ & $\begin{array}{r}27.13 \\
49.23 \\
23.64\end{array}$ & $\begin{array}{l}18.11 \\
53.13 \\
18.76\end{array}$ & $\begin{array}{r}-9.02 \\
+13.90 \\
-.4 .38\end{array}$ \\
\hline $14-15$ & $\begin{array}{l}(+) \\
(0) \\
(-)\end{array}$ & $\begin{array}{l}18.49 \\
56.82 \\
15.69\end{array}$ & $\begin{array}{l}16.00 \\
66.80 \\
17.20\end{array}$ & $\begin{array}{l}-2.49 \\
+9.98 \\
+1.51\end{array}$ & $14-15$ & $\begin{array}{l}(+) \\
(0 \\
(-)\end{array}$ & $\begin{array}{l}17.09 \\
66.38 \\
16.53\end{array}$ & $\begin{array}{l}17.33 \\
67.50 \\
15.07\end{array}$ & $\begin{array}{r}+0.24 \\
+1.22 \\
-1.46\end{array}$ \\
\hline $15-16$ & $\begin{array}{l}(+) \\
(0) \\
(-)\end{array}$ & $\begin{array}{r}15.77 \\
74.93 \\
9.30\end{array}$ & $\begin{array}{l}19.49 \\
65.30 \\
15.21\end{array}$ & $\begin{array}{l}+3.72 \\
-9.63 \\
+5.91\end{array}$ & $15-16$ & $\begin{array}{l}(+) \\
(-)\end{array}$ & $\begin{array}{l}14.08 \\
75.78 \\
10.14\end{array}$ & $\begin{array}{l}20.68 \\
61.62 \\
14.70\end{array}$ & $\begin{array}{r}+6.60 \\
-11.16 \\
+4.56\end{array}$ \\
\hline $16-17$ & $\begin{array}{l}(+) \\
(0) \\
(-)\end{array}$ & $\begin{array}{r}14.45 \\
76.20 \\
9.35\end{array}$ & $\begin{array}{l}21.32 \\
62.63 \\
16.05\end{array}$ & $\begin{array}{r}+6.87 \\
-13.57 \\
+6.70\end{array}$ & $16-17$ & $\begin{array}{l}(+) \\
(0) \\
(-)\end{array}$ & $\begin{array}{r}13.83 \\
78.19 \\
7.90\end{array}$ & $\begin{array}{l}20.0 \\
65.26 \\
14.74\end{array}$ & $\begin{array}{r}16.12 \\
+12.93 \\
+5.81\end{array}$ \\
\hline $17-18$ & $\begin{array}{l}(+) \\
(0) \\
(-)\end{array}$ & $\begin{array}{r}11.61 \\
81.94 \\
6.45\end{array}$ & $\begin{array}{l}17.35 \\
72.15 \\
10.50\end{array}$ & $\begin{array}{l}+5.74 \\
-9.77 \\
+4.05\end{array}$ & $17-18$ & $\begin{array}{l}(+) \\
(0) \\
(-)\end{array}$ & $\begin{array}{r}11.61 \\
81.94 \\
6.45\end{array}$ & $\begin{array}{r}19.63 \\
71.24 \\
9.13\end{array}$ & $\begin{array}{r}+8.02 \\
-10.70 \\
+2.68\end{array}$ \\
\hline $18-19$ & $\begin{array}{l}(+) \\
(0) \\
(-)\end{array}$ & $\begin{array}{r}15.96 \\
77.13 \\
6.97\end{array}$ & $\begin{array}{l}- \\
-\end{array}$ & $\overline{-}$ & $18-19$ & $\begin{array}{l}(+) \\
(0) \\
(-)\end{array}$ & $\begin{array}{r}14.36 \\
81.92 \\
3.72\end{array}$ & $=$ & $\bar{z}$ \\
\hline $19-20$ & $\begin{array}{l}(+) \\
(\mathrm{O})\end{array}$ & $\begin{array}{r}20.23 \\
71.68 \\
8 \mathrm{Ca}\end{array}$ & $=$ & $\underline{-}$ & $19-20$ & $\begin{array}{l}(+) \\
(0) \\
(-)\end{array}$ & $\begin{array}{r}13.87 \\
81.51 \\
4.62\end{array}$ & $=$ & $\bar{z}$ \\
\hline
\end{tabular}

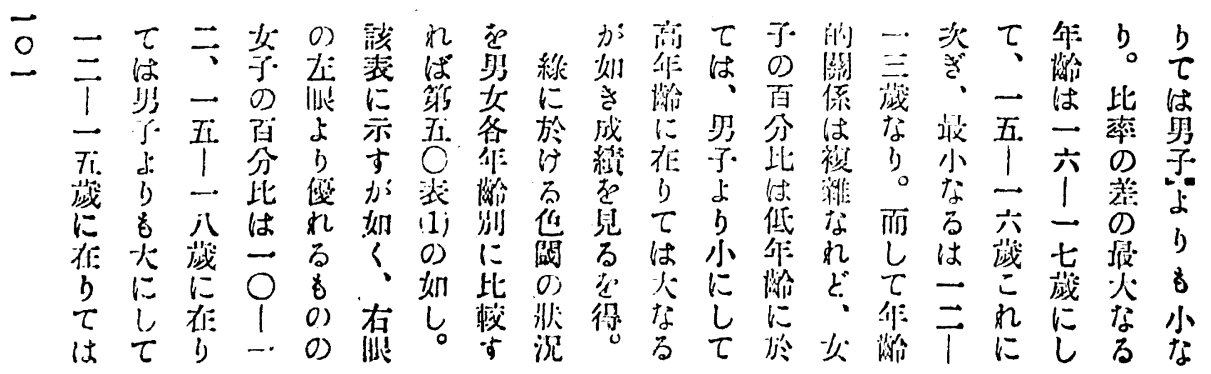




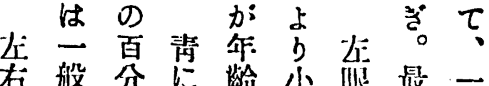

㜀に比於となの小二

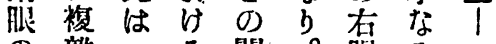

の㯇 一る關。眼る一

同な○色係共占は五

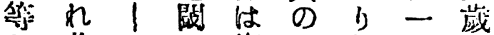

小共二U椱此㯪一に

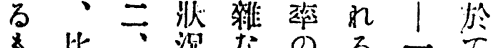

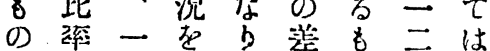

〉の四男。のの荹罗

女啳 1 女最》李子

子 $の$ - 大 女 b

》. 㜊公各な子。

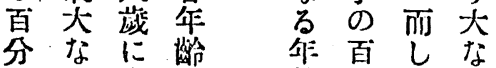

比在别分分 $\tau$ 。

は年 $b$.

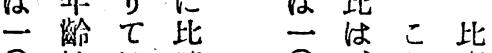

○はは粉 0 和染

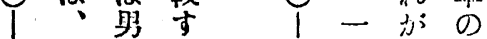

一一手れ 一 0 胙澄

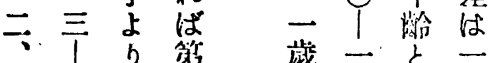

一一小五 に一更般

五四に○、塯に

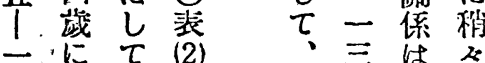

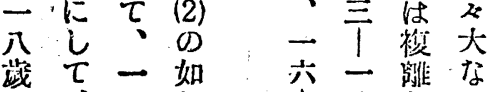

於一 $\vec{T}$ 而 1 公な

宁七十印; 七些。

は 1 四 古能在

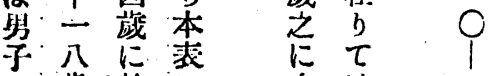

ま战・於に次は息

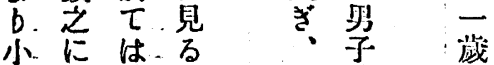

に次等方 最上比

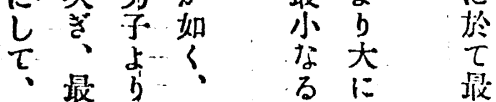

第五十一表

\begin{tabular}{|c|c|c|c|c|}
\hline \multicolumn{5}{|c|}{ 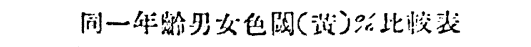 } \\
\hline S辰 鿘 & & 界品 & 尖皆 & 形 \\
\hline $10-11$ & $\mid \begin{array}{l}(+) \\
(0) \\
(-)\end{array}$ & $\begin{array}{l}24.6 \\
56.65 \\
15.79\end{array}$ & $\begin{array}{l}25.5 \\
46.26 \\
23.19\end{array}$ & $\begin{array}{r}+0.94 \\
-3.39 \\
+12.40\end{array}$ \\
\hline $11-12$ & $\begin{array}{l}(+) \\
(0) \\
(-)\end{array}$ & $\begin{array}{l}23 .-4 \\
57.70 \\
19.06\end{array}$ & $\begin{array}{l}25.90 \\
53.59 \\
20.51\end{array}$ & $\begin{array}{l}+1.66 \\
-4.11 \\
+1.45\end{array}$ \\
\hline $12-13$ & $\begin{array}{l}(+) \\
(0) \\
(-)\end{array}$ & $\begin{array}{l}24.58 ! \\
49.57 \\
25.85\end{array}$ & $\begin{array}{l}25.11 \\
50.15 \\
21.11\end{array}$ & $\begin{array}{r}+0.53 \\
-0.88 \\
-1.41\end{array}$ \\
\hline $13-14$ & $\begin{array}{l}(+) \\
(0) \\
(-) !\end{array}$ & $\begin{array}{l}34.11 ! \\
41.47 \\
24.42\end{array}$ & $\begin{array}{l}27.81 \\
53.17 \\
19.02\end{array}$ & $\begin{array}{r}-6.30 \\
+11.70 \\
--5.40\end{array}$ \\
\hline $14-15$ & $\begin{array}{l}(-1-) \\
(0) \\
(-)\end{array}$ & $\begin{array}{l}27,45 \\
52.10 \\
20.45\end{array}$ & $\begin{array}{l}18.13 \\
63.6 C \\
18.27\end{array}$ & $\begin{array}{r}-9.2 \\
-11.50 \\
-1.18\end{array}$ \\
\hline $15-16$ & $\begin{array}{l}(+) \\
(-) \\
(-)\end{array}$ & $\begin{array}{l}18.31 \\
69.73 \\
12.96\end{array}$ & $\begin{array}{l}20.34 \\
62.74 \\
16.92\end{array}$ & $\begin{array}{r}+2.03 \\
-5.99 \\
+3.96\end{array}$ \\
\hline $16-17$ & $\begin{array}{l}(-1-) \\
(0) \\
(-)\end{array}$ & $\begin{array}{l}13.60 \\
75.07 \\
11.33\end{array}$ & $\begin{array}{l}19.21 \\
66.58 \\
1.4 .21\end{array}$ & $\begin{array}{l}+5.61 \\
+8.49 \\
+\quad .83\end{array}$ \\
\hline $17-18$ & $\begin{array}{l}(+) \\
(0) \\
(-)\end{array}$ & $\begin{array}{r}15.16 \\
76.78 \\
8.06\end{array}$ & $\begin{array}{l}17.35 \\
68 . C 4 \\
14.61\end{array}$ & $\begin{array}{r}+2.19 \\
-8.74 \\
+6.55\end{array}$ \\
\hline $18-19$ & $\begin{array}{l}(+) \\
(0) \\
(5)\end{array}$ & $\begin{array}{r}19.68 \\
76.06 \\
4.26\end{array}$ & - & - \\
\hline $19+20$ & $\begin{array}{l}(+) \\
(0) \\
(-)\end{array}$ & $\begin{array}{l}17.34 \\
71.69 \\
10.98\end{array}$ & - & - \\
\hline
\end{tabular}

二小夲右 はし 太

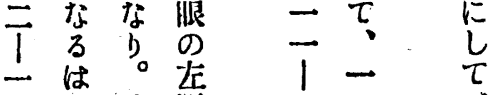

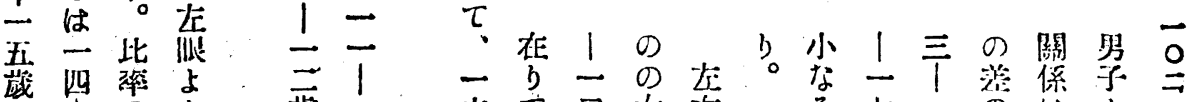

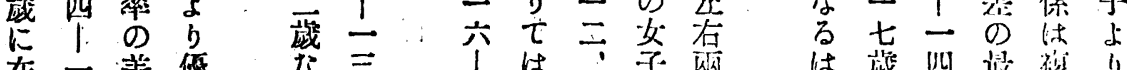

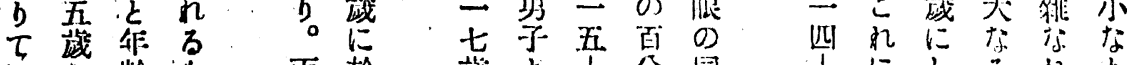

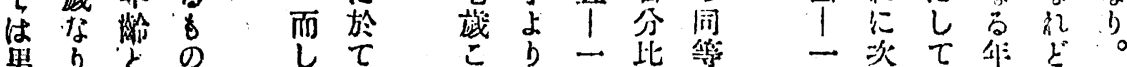

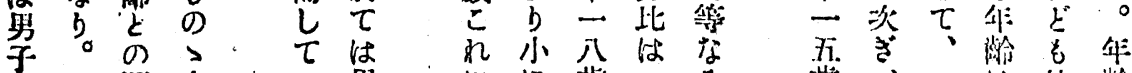

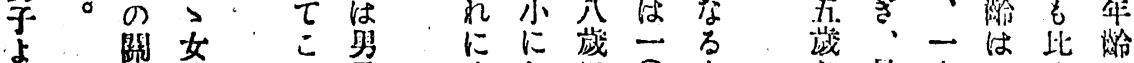

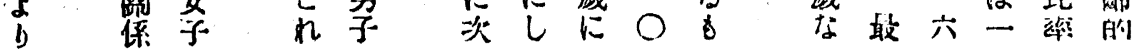




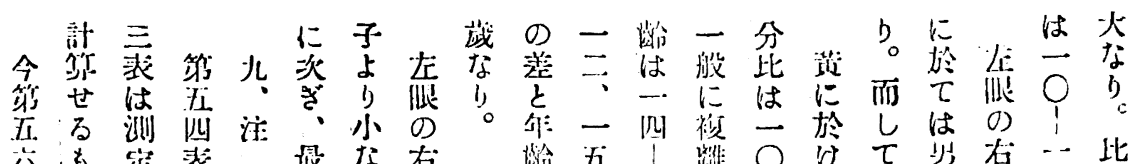

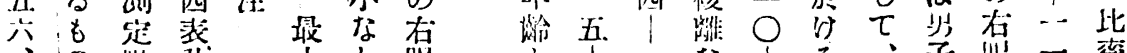

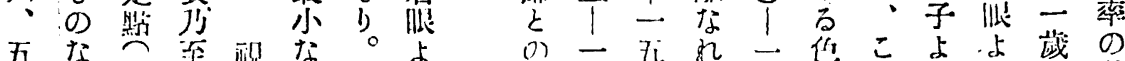

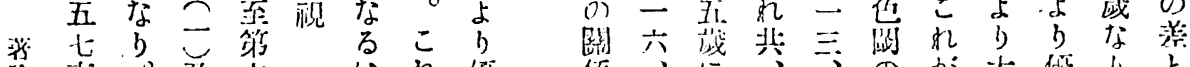

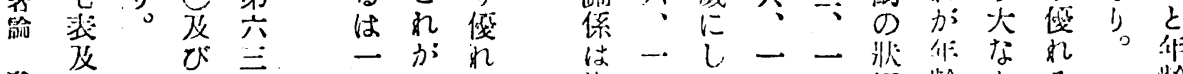

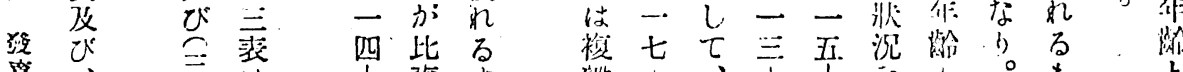

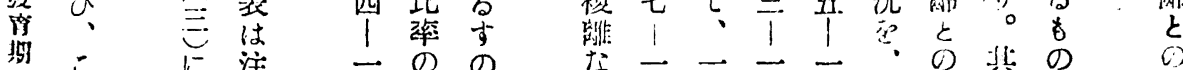

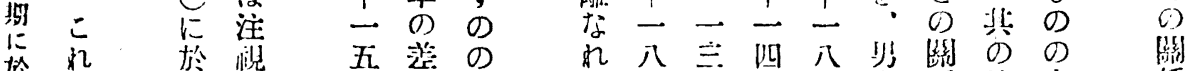

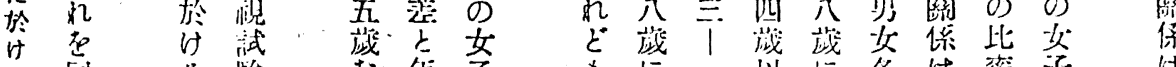

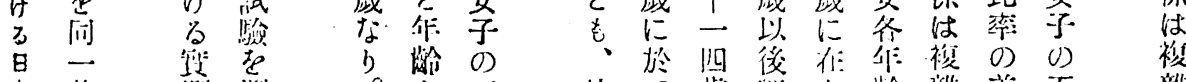

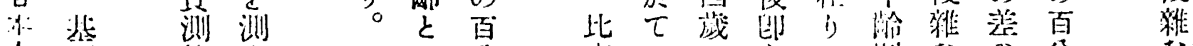

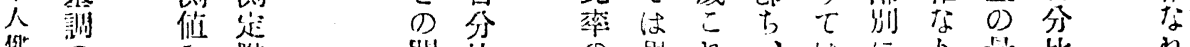

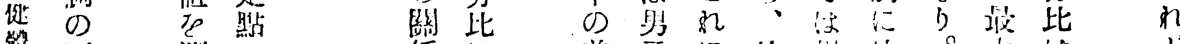

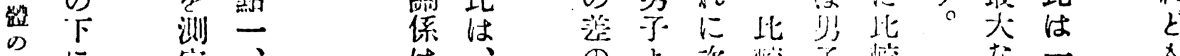

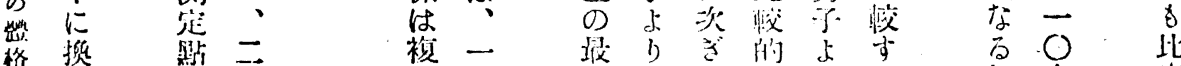

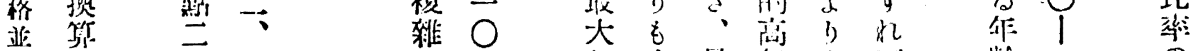

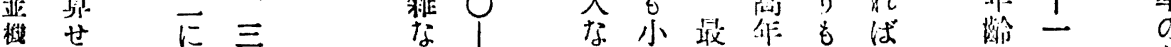
能 $儿$ 路

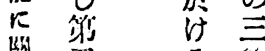

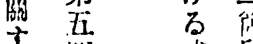

3 四, 成所

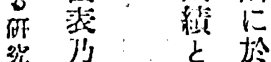

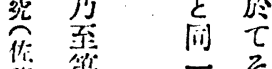

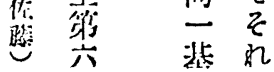

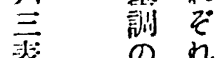

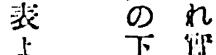

b) k 测

笲比せ

五较 る

翌 棌

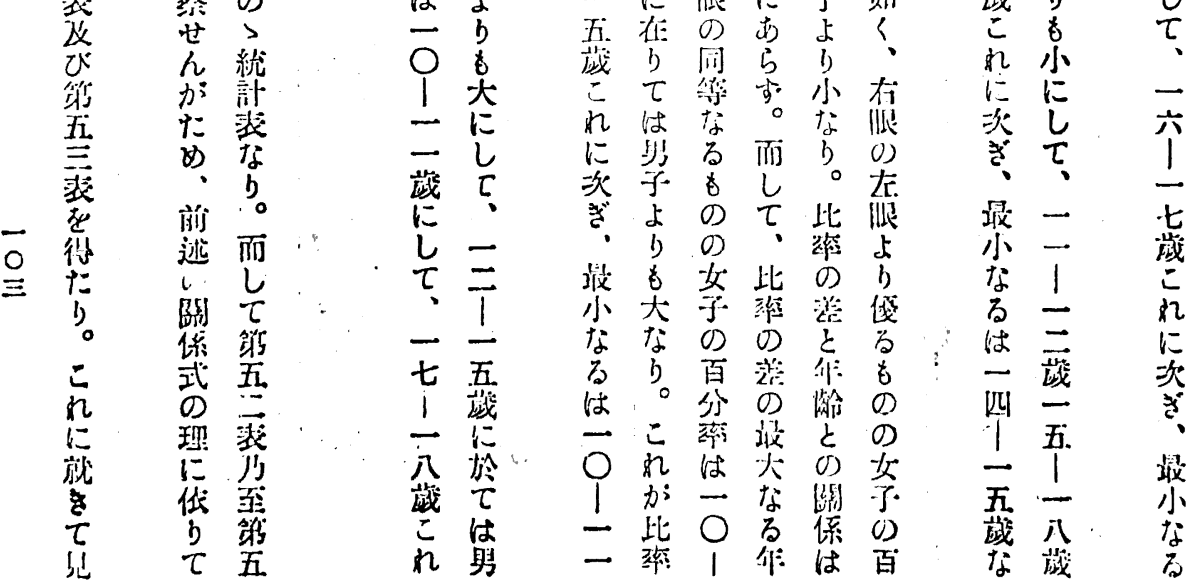

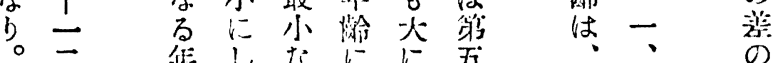

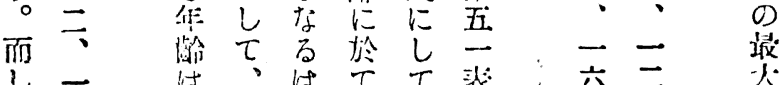

五五

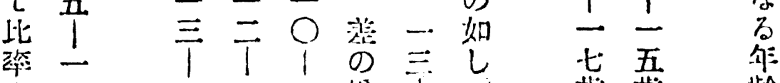

の八

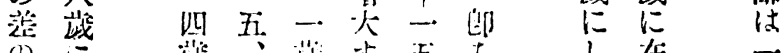

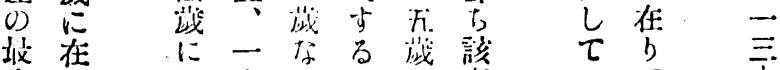

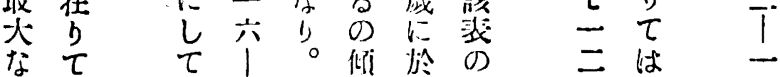

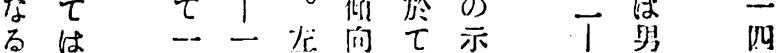

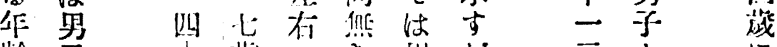

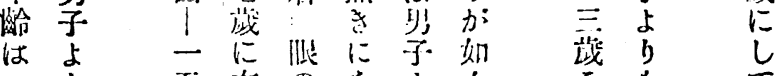




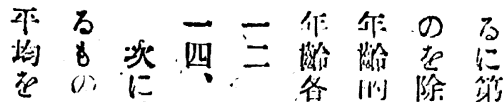

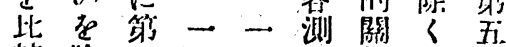

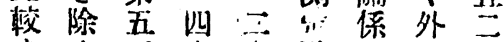

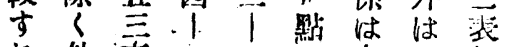

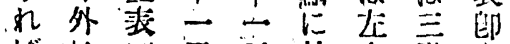

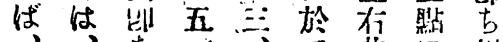

、古、正基四

各至女一二管に疑了

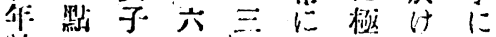

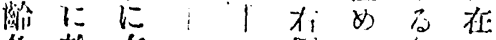

爷於在一一侧 $\tau$ 各 $b$

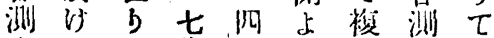

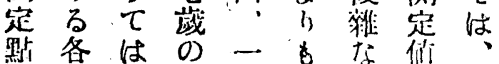

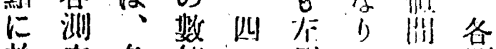

於定各俏!! 侧とに测

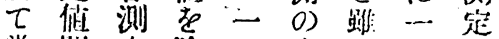

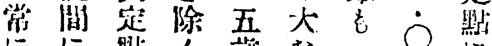

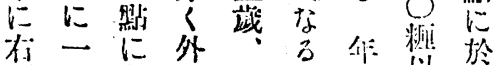

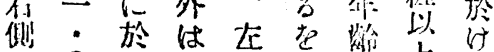

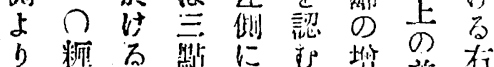

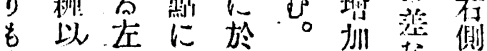

左.上右於て次々な少

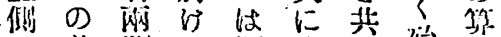

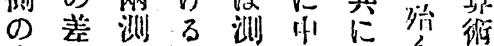

大な

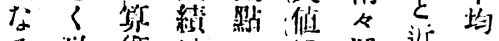

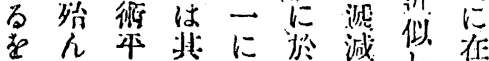

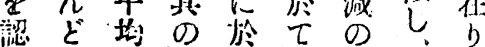

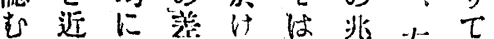

似在 何

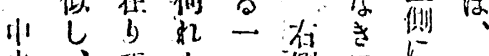

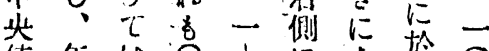

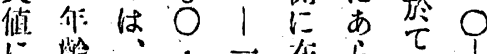

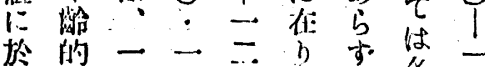

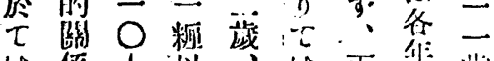

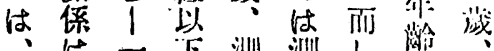

右

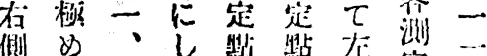

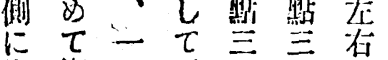

在複一。丕にに元

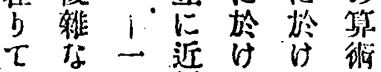

はb 二似るる本 近

二、藏せ方出似润

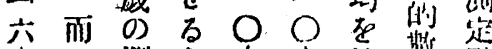

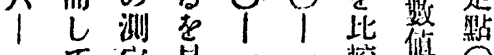

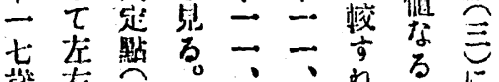

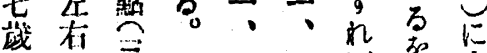

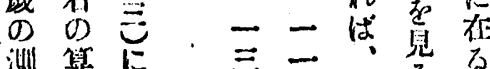

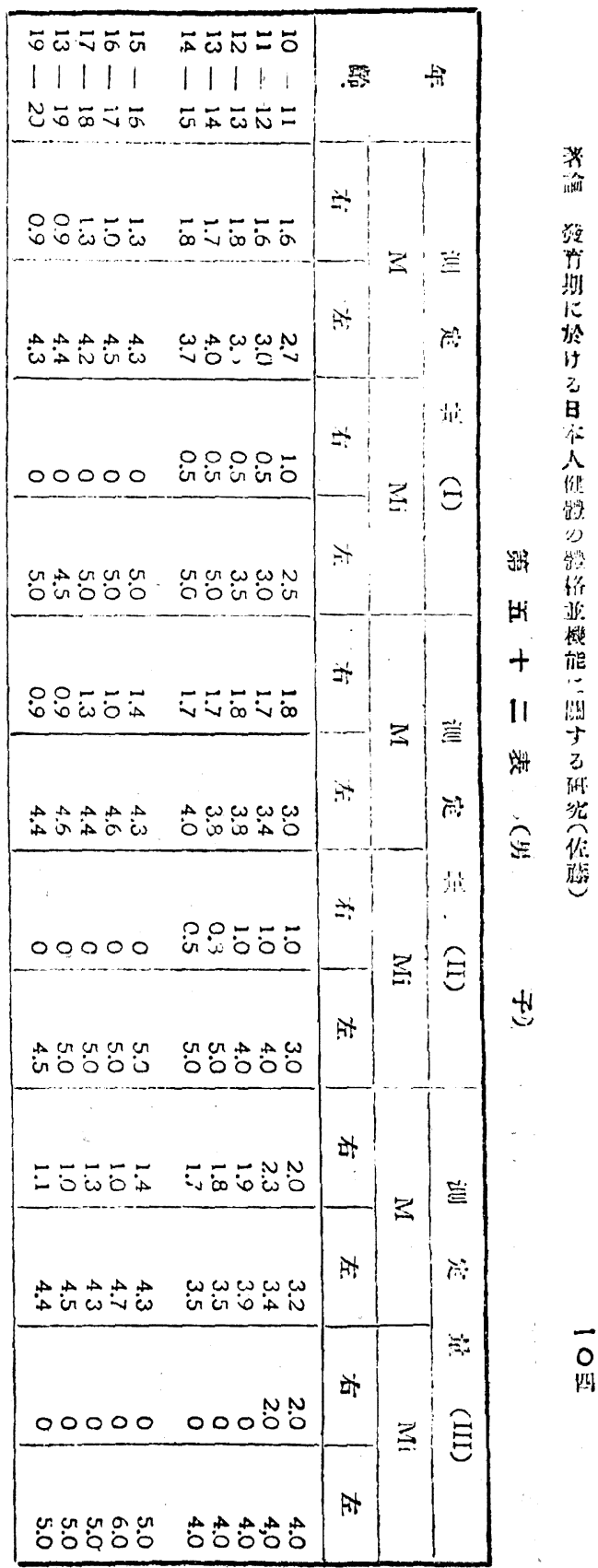

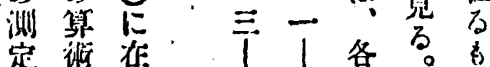


IV 215

七 - 第裴 第十

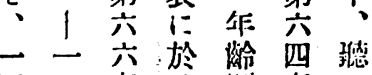

四二韯汀别表

1茷の:万統は

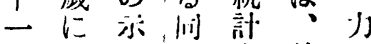

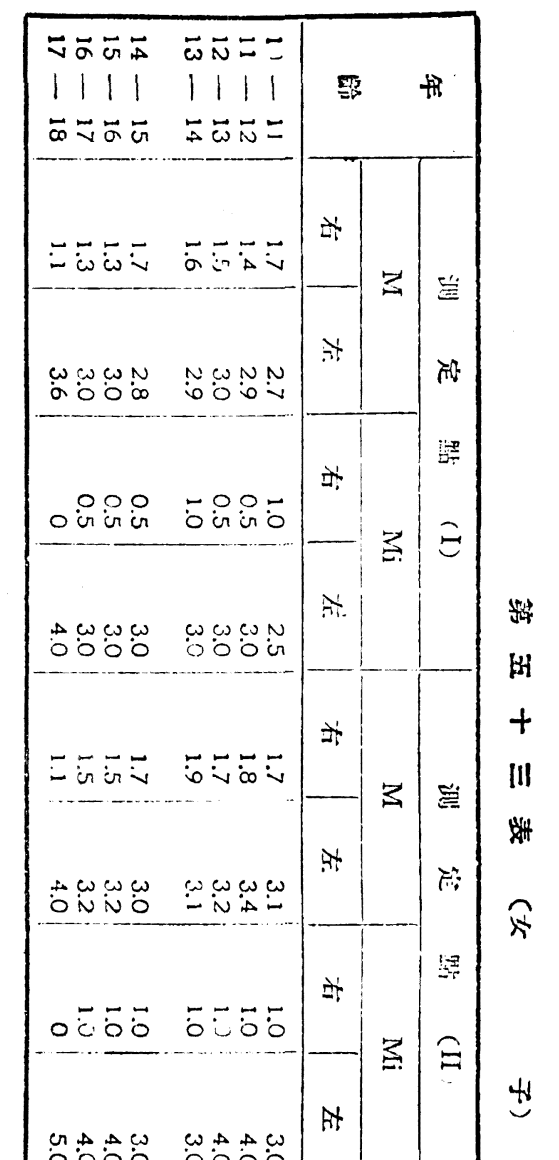

引三 三

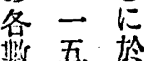

倠

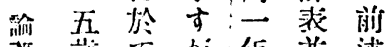

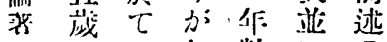

こ如则 に

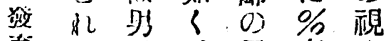

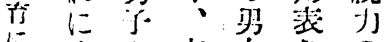

に炏上 2⿺ 女子小

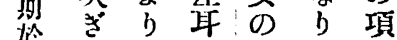

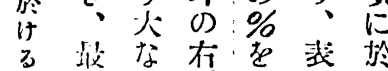

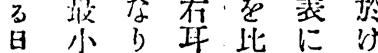

冰な、占校示る

人るこりす士

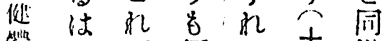

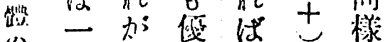

捗 $\bigcirc$ 比没第はな

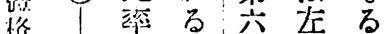

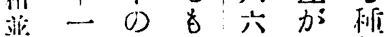

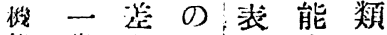

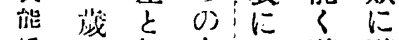

にな俳久示德独

㯡 b 解

$-0 \xi \omega$ 占

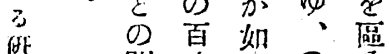

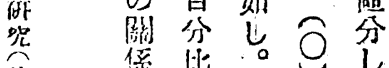

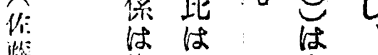

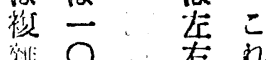

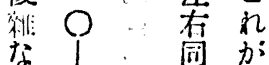

小 $\therefore$ 同

而二: 具

而、 $气 气$ 型

乙二 汇に

比 $丁$ 疮分

管 - 加

○八 能老

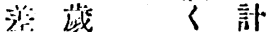

のに衡算

枝在こせ

$\therefore$ 少舟

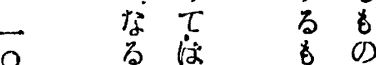

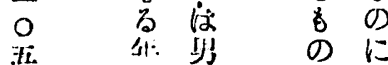

制宁 $>$ L

は占記て

二

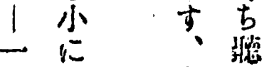

二 今 势

$\omega \quad \omega+\Delta$

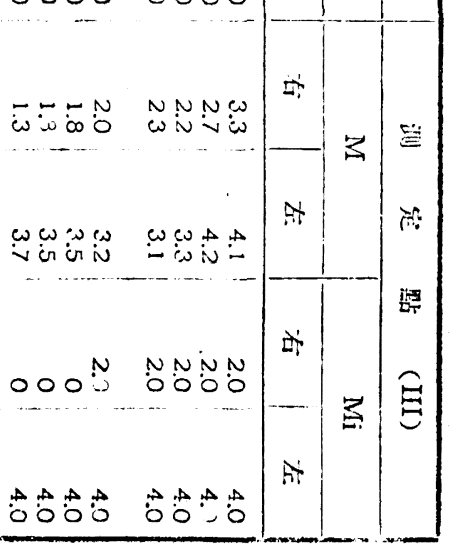

蛋六。

亦

は六 0

多 1

h $\overrightarrow{1}-$

源战㽣

似 に 少

也於至

万 $\overrightarrow{ } \vec{x}$

者五

觉测 政 


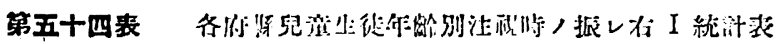

\begin{tabular}{|c|c|c|c|c|c|c|c|c|}
\hline \multirow{2}{*}{ 性 } & \multirow{2}{*}{ 年 跧 } & \multirow{2}{*}{$\mathrm{N}$} & \multirow{2}{*}{$\mathrm{M}$} & \multicolumn{3}{|c|}{ V } & \multirow{2}{*}{\multicolumn{2}{|c|}{$\mathrm{Mi}$}} \\
\hline & & & & Max & Min & & & \\
\hline $\begin{array}{c}\because \\
\because \\
\because \\
\text { 田 } \\
\vdots \\
\vdots\end{array}$ & $\begin{array}{r}10-11 \\
11-12 \\
12-13 \\
13-14 \\
14-15 \\
15-16 \\
\therefore 16-17 \\
17-18 \\
18-19 \\
19-20\end{array}$ & $\begin{array}{l}223 \\
383 \\
2: 6 \\
258 \\
357 \\
\\
355 \\
353 \\
310 \\
188 \\
173\end{array}$ & $\begin{array}{l}2.8 \\
3.0 \\
3.4 \\
3.1 \\
3.4 \\
\\
2.4 \\
1.9 \\
2.4 \\
1.7 \\
1.7\end{array}$ & $\begin{array}{l}120 \\
13.0 \\
15.0 \\
13.0 \\
13.0 \\
\\
15.0 \\
140 \\
15.0 \\
13.0 \\
13.0\end{array}$ & 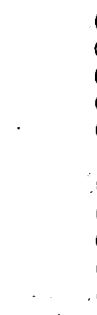 & $\begin{array}{l}0 \\
0 \\
0 \\
0 \\
0 \\
0 \\
0 \\
0 \\
0 \\
0 \\
0\end{array}$ & $\begin{array}{l}2 \\
1 \\
1 \\
1 \\
1\end{array}$ & $\begin{array}{l}2.0 \\
1.2 \\
1.0 \\
1.0 \\
10 \\
\\
0 \\
0 \\
0 \\
0 \\
0\end{array}$ \\
\hline 女 & $\begin{array}{l}10-11 \\
11-12 \\
12-13 \\
13-14 \\
14-15 \\
15-16 \\
16-17 \\
17-18\end{array}$ & $\begin{array}{l}227 \\
390 \\
446 \\
773 \\
\\
750 \\
5 \subseteq 5 \\
380 \\
219\end{array}$ & $\begin{array}{l}2.9 \\
2.5 \\
2.7 \\
2.9 \\
\\
3.0 \\
2.3 \\
2.3 \\
20\end{array}$ & $\begin{array}{l}10.0 \\
12.0 \\
12.0 \\
13.0 \\
120 \\
12.0 \\
11.0 \\
12.0\end{array}$ & 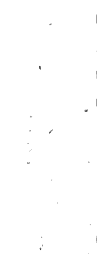 & $\begin{array}{l}0 \\
0 \\
0 \\
0\end{array}$ & $\begin{array}{l}2 \\
1 \\
1 \\
1\end{array}$ & $\begin{array}{l}2.0 \\
1.0 \\
1.0 \\
1.0\end{array}$ \\
\hline
\end{tabular}

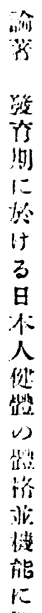

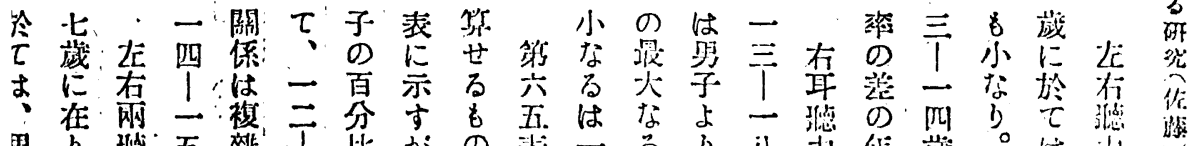

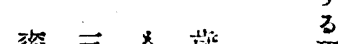

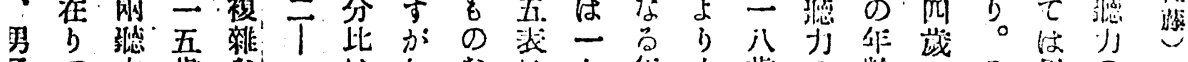

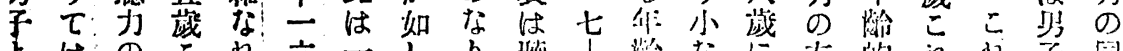

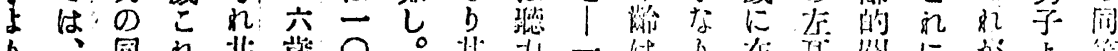

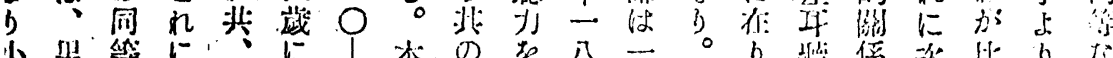

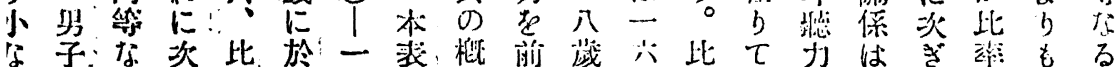

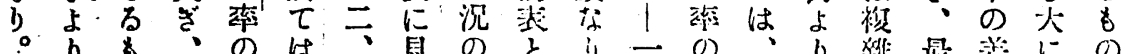

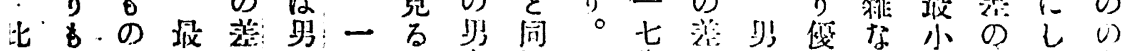

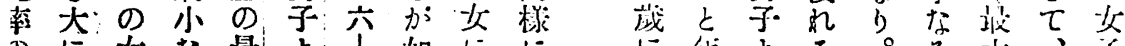

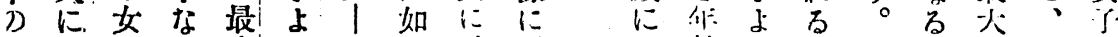

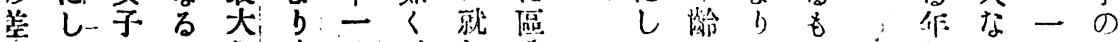

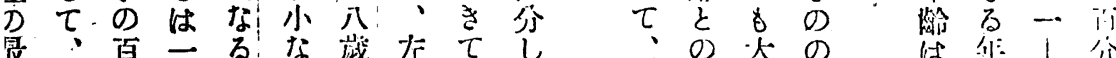

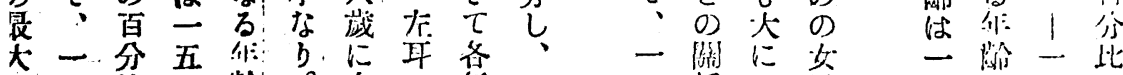

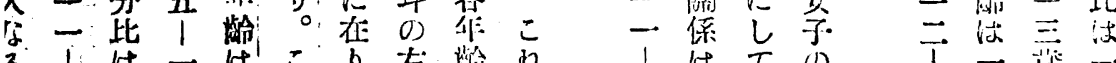

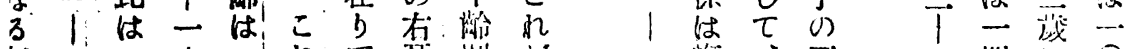

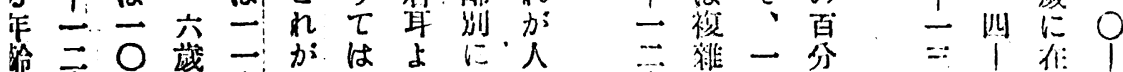

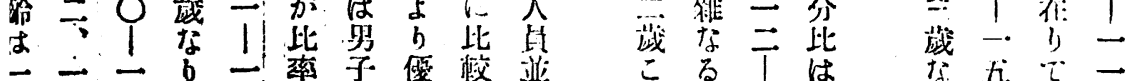

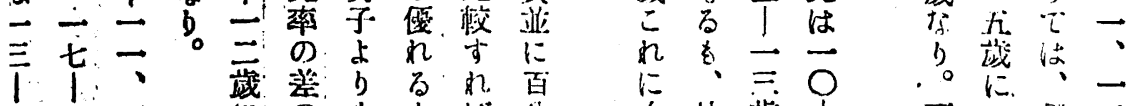

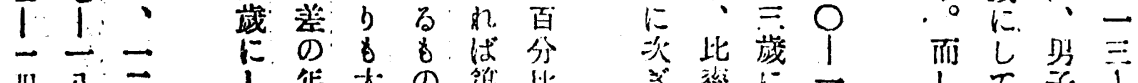

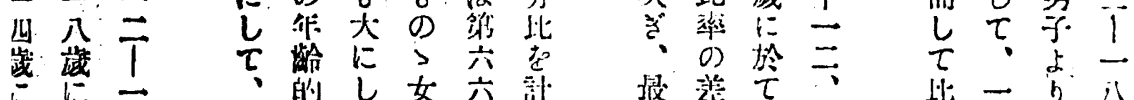




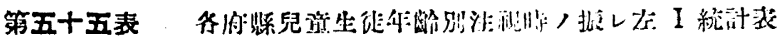

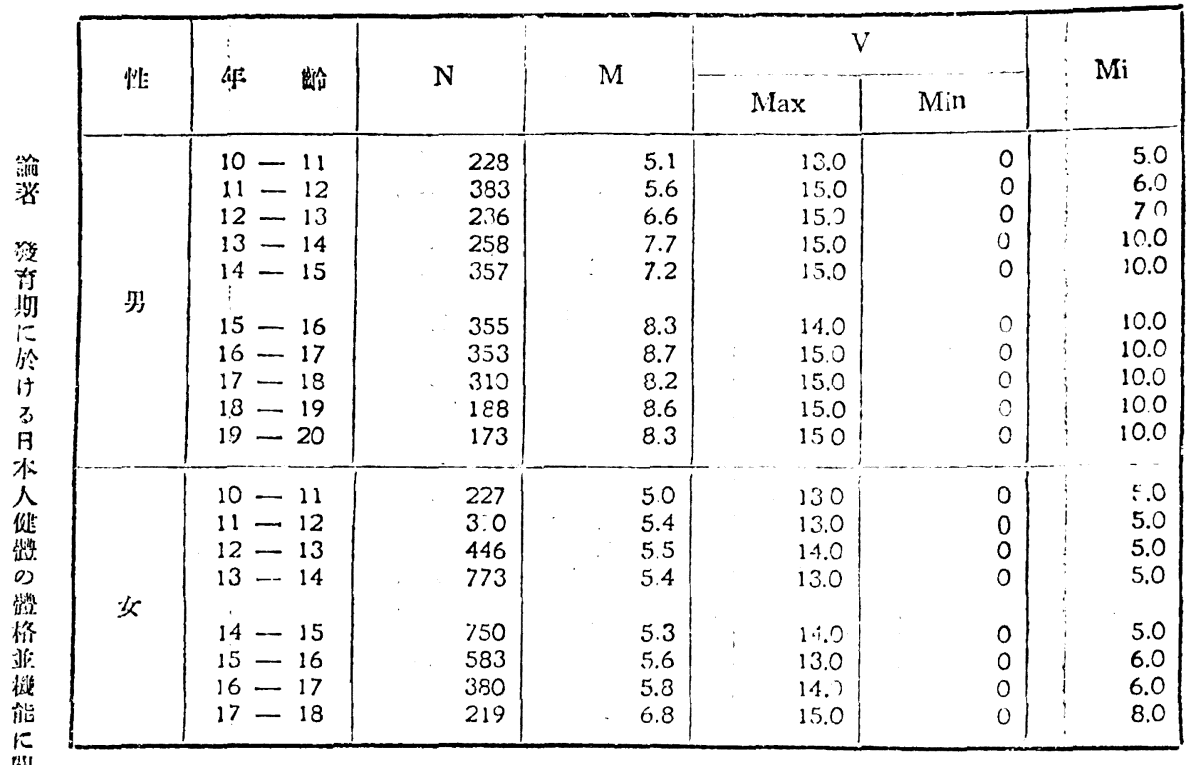

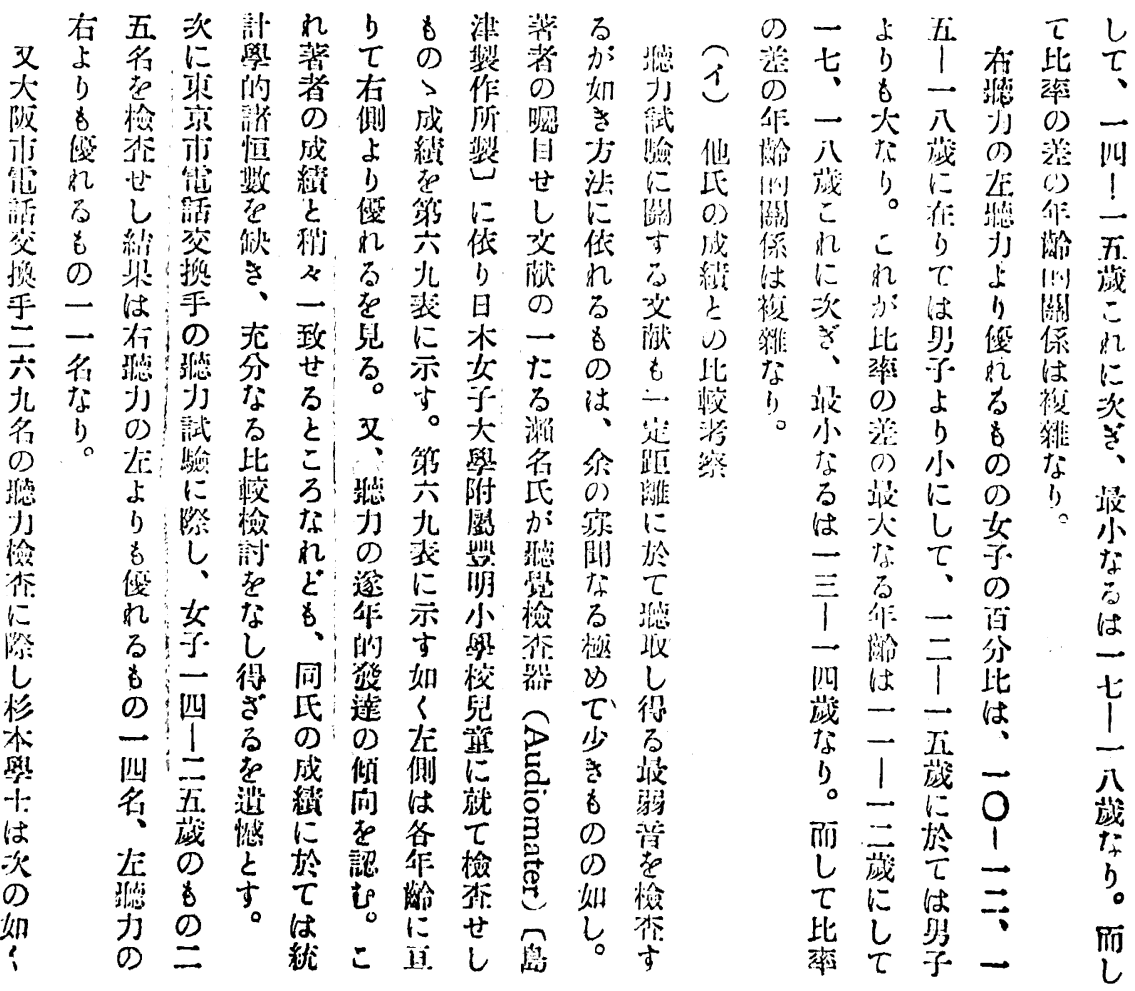




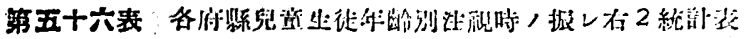

\begin{tabular}{|c|c|c|c|c|c|c|c|}
\hline 证 & A: & 的位 & $N$ & $M$ & $\operatorname{Max}$ & Min & $\mathrm{Mi}$ \\
\hline $\begin{array}{c}\because \\
\text { 另 } \\
\vdots\end{array}$ & $\begin{array}{l}10-1 \\
11-1 \\
12-1 \\
13-1 \\
14-1 \\
15-1 \\
16-1 \\
17-1 \\
18-1 \\
19-2\end{array}$ & $\begin{array}{l}11 \\
12 \\
13 \\
14 \\
15 \\
\\
16 \\
17 \\
18 \\
19 \\
20\end{array}$ & $\begin{array}{l}228 \\
383 \\
236 \\
258 \\
357 \\
\\
255 \\
353 \\
310 \\
188 \\
173\end{array}$ & $\begin{array}{l}1.8 \\
1.7 \\
1.8 \\
1.7 \\
1.7 \\
\\
1.4 \\
1.0 \\
1.3 \\
0.9 \\
0.9\end{array}$ & $\begin{array}{r}6.0 \\
10.0 \\
10.0 \\
6.1 \\
9.0 \\
\\
7.5 \\
7.0 \\
10.0 \\
7.0 \\
7.0\end{array}$ & $\begin{array}{l}0 \\
0 \\
0 \\
0 \\
0 \\
\\
0 \\
0 \\
0 \\
0 \\
0\end{array}$ & $\begin{array}{l}10 \\
1.0 \\
1.0 \\
0.8 \\
0.5 \\
0 \\
0 \\
0 \\
0 \\
0\end{array}$ \\
\hline $\begin{array}{l}: \\
\text { 女 }\end{array}$ & $\begin{array}{l}10-1 \\
11-1 \\
12-1 \\
13-1 \\
14-1 \\
15-1 \\
16-1 \\
17-1\end{array}$ & $\begin{array}{l}11 \\
12 \\
13 \\
14 \\
\\
15 \\
16 \\
17 \\
18\end{array}$ & $\begin{array}{l}227 \\
390 \\
446 \\
773 \\
750 \\
585 \\
380 \\
219\end{array}$ & $\begin{array}{l}1.7 \\
1.8 \\
1.7 \\
1.9 \\
1.7 \\
1.5 \\
1.4 \\
1.1\end{array}$ & $\begin{array}{l}9.0 \\
9.0 \\
8.0 \\
8.0 \\
7.0 \\
6.5 \\
6.5 \\
6.0\end{array}$ & $\begin{array}{l}0 \\
0 \\
0 \\
0 \\
0 \\
0 \\
0 \\
0\end{array}$ & $\begin{array}{l}1.0 \\
1.0 \\
1.0 \\
1.0 \\
1.0 \\
1.0 \\
0 \\
0\end{array}$ \\
\hline
\end{tabular}

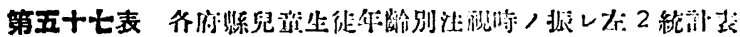

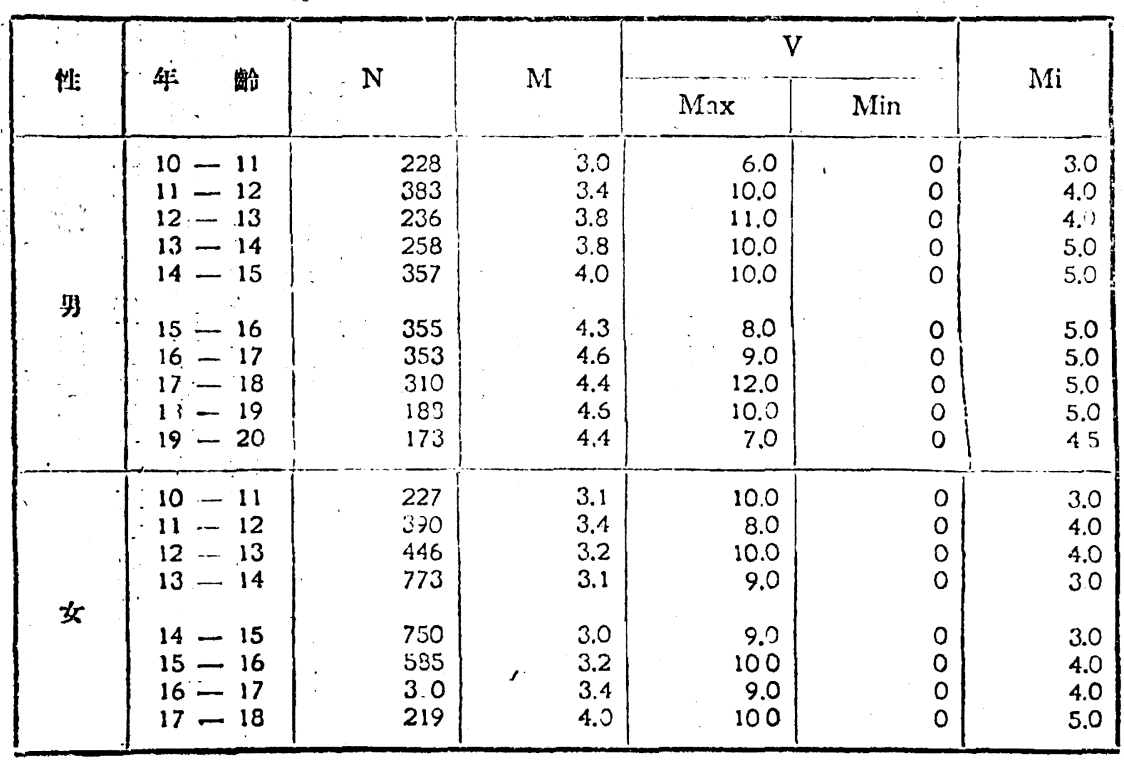




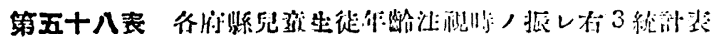

\begin{tabular}{|c|c|c|c|c|c|c|}
\hline 怢: & 位: 龄 & $\mathrm{N}$ & $\mathrm{M}$ & Max & Min & $\mathrm{Mi}$ \\
\hline 男 & $\begin{array}{l}10-11 \\
11-12 \\
12-13 \\
13-14 \\
14-\cdots 15 \\
15-16 \\
15-17 \\
16-17 \\
17-18 \\
18-19 \\
19-20\end{array}$ & $\begin{array}{l}228 \\
: 83 \\
226 \\
253 \\
3.7 \\
\\
355 \\
353 \\
310 \\
183 \\
173\end{array}$ & $\begin{array}{l}1.3 \\
1.2 \\
1.0 \\
0.9 \\
0.9 \\
0.7 \\
0.6 \\
0.7 \\
0.5 \\
0.6\end{array}$ & $\begin{array}{r}6.0 \\
10.0 \\
100 \\
8.0 \\
50 \\
\\
6.0 \\
12.0 \\
4.0 \\
4.0 \\
5 .\end{array}$ & $\begin{array}{l}0 \\
0 \\
0 \\
0 \\
0 \\
0 \\
0 \\
0 \\
0 \\
0 \\
0\end{array}$ & $\begin{array}{r}10 \\
1.0 \\
0 \\
0 \\
0 \\
0 \\
0 \\
0 \\
0 \\
0\end{array}$ \\
\hline 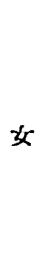 & $\begin{array}{l}10-11 \\
11-12 \\
12=13 \\
13-14 \\
14-15 \\
15-16 \\
16-17 \\
17-18\end{array}$ & $\begin{array}{l}227 \\
370 \\
446 \\
773 \\
\\
750 \\
5 ? 5 \\
380 \\
219\end{array}$ & $\begin{array}{l}1.7 \\
1.5 \\
1.1 \\
1.2 \\
\\
1.3 \\
0.8 \\
0.8 \\
0.7\end{array}$ & $\begin{array}{r}1.0 \\
10.0 \\
9.0 \\
11.0 \\
6.0 \\
8.0 \\
8.0 \\
5.0\end{array}$ & $\begin{array}{l}0 \\
0 \\
0 \\
0 \\
0 \\
0 \\
0 \\
0\end{array}$ & $\begin{array}{l}1.0 \\
1.0 \\
1.0 \\
1.0\end{array}$ \\
\hline
\end{tabular}

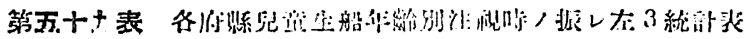

\begin{tabular}{|c|c|c|c|c|c|c|c|}
\hline 性: & 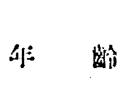 & $\mathrm{N}$ & $\mathbf{M}$ & $\operatorname{Max}$ & Min & & $\mathrm{Mi}$ \\
\hline 男 & $\begin{array}{l}13-11 \\
1.12 \\
12=13 \\
13=14 \\
: 4=15 \\
15-16 \\
16=17 \\
17=18 \\
18=19 \\
19=20\end{array}$ & $\begin{array}{l}228 \\
383 \\
2: 6 \\
259 \\
357 \\
\\
355 \\
353 \\
310 \\
188 \\
173\end{array}$ & $\begin{array}{l}1.7 \\
1.8 \\
2.1 \\
1.8 \\
1.8 \\
2.5 \\
2.4 \\
2.3 \\
2.4 \\
2.3\end{array}$ & $\begin{array}{r}5.0 \\
11.0 \\
12.0 \\
6.0 \\
9.0 \\
\\
5.0 \\
5.0 \\
4.0 \\
5.0 \\
5.0\end{array}$ & & $\begin{array}{l}0 \\
0 \\
0 \\
0 \\
0 \\
0 \\
0 \\
0 \\
0 \\
0 \\
0\end{array}$ & $\begin{array}{l}2.0 \\
2.0 \\
2.0 \\
2.0 \\
2.0 \\
\\
\\
2.5 \\
3.0 \\
2.5 \\
2.5 \\
2.5\end{array}$ \\
\hline 火 & $\begin{array}{l}10-11 \\
11=12 \\
12=13 \\
13-14 \\
14-15 \\
15=16 \\
16-17 \\
17-18\end{array}$ & $\begin{array}{l}227 \\
390 \\
446 \\
; 73 \\
\\
750 \\
585 \\
380 \\
219\end{array}$ & $\begin{array}{l}2.1 \\
2.1 \\
1.7 \\
1.6 \\
1.7 \\
1.9 \\
1.8 \\
2.0\end{array}$ & $\begin{array}{r}9.0 \\
10.0 \\
8.0 \\
0.0 \\
11.0 \\
12.0 \\
8.0 \\
4.0\end{array}$ & & $\begin{array}{l}0 \\
0 \\
0 \\
0\end{array}$ & $\begin{array}{l}2.0 \\
2.0 \\
2.0 \\
2.0 \\
2.0 \\
2.0 \\
2.0 \\
2.0\end{array}$ \\
\hline
\end{tabular}




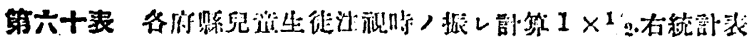

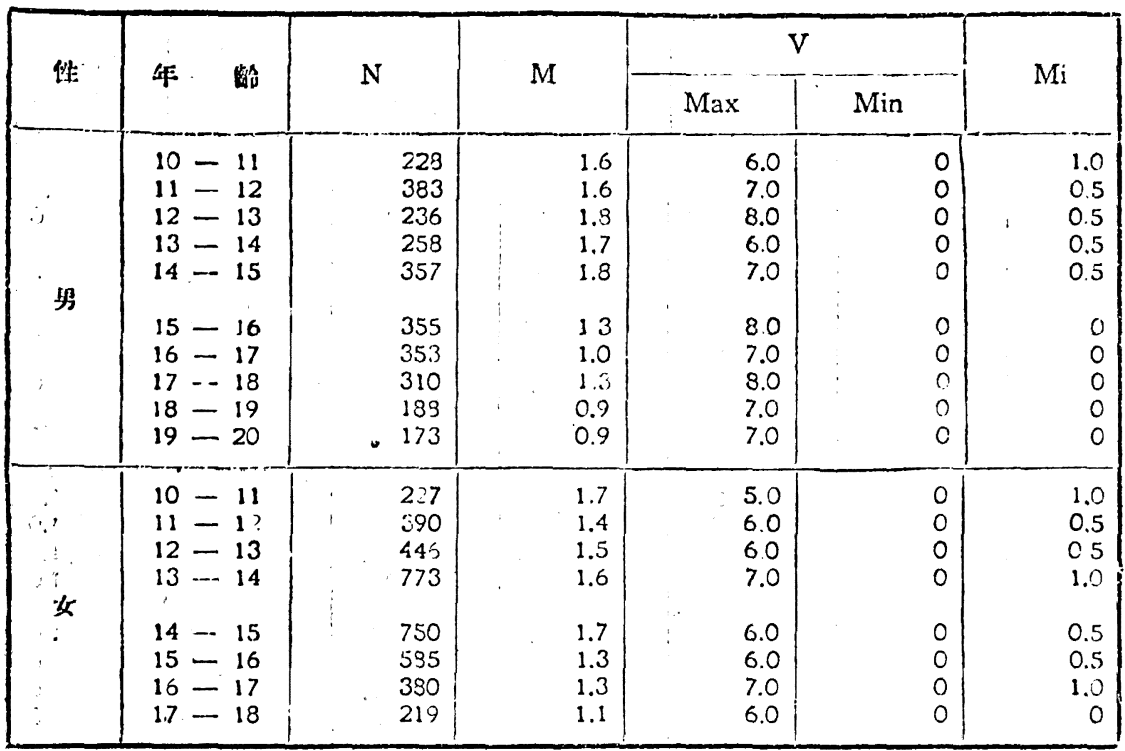

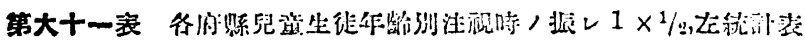

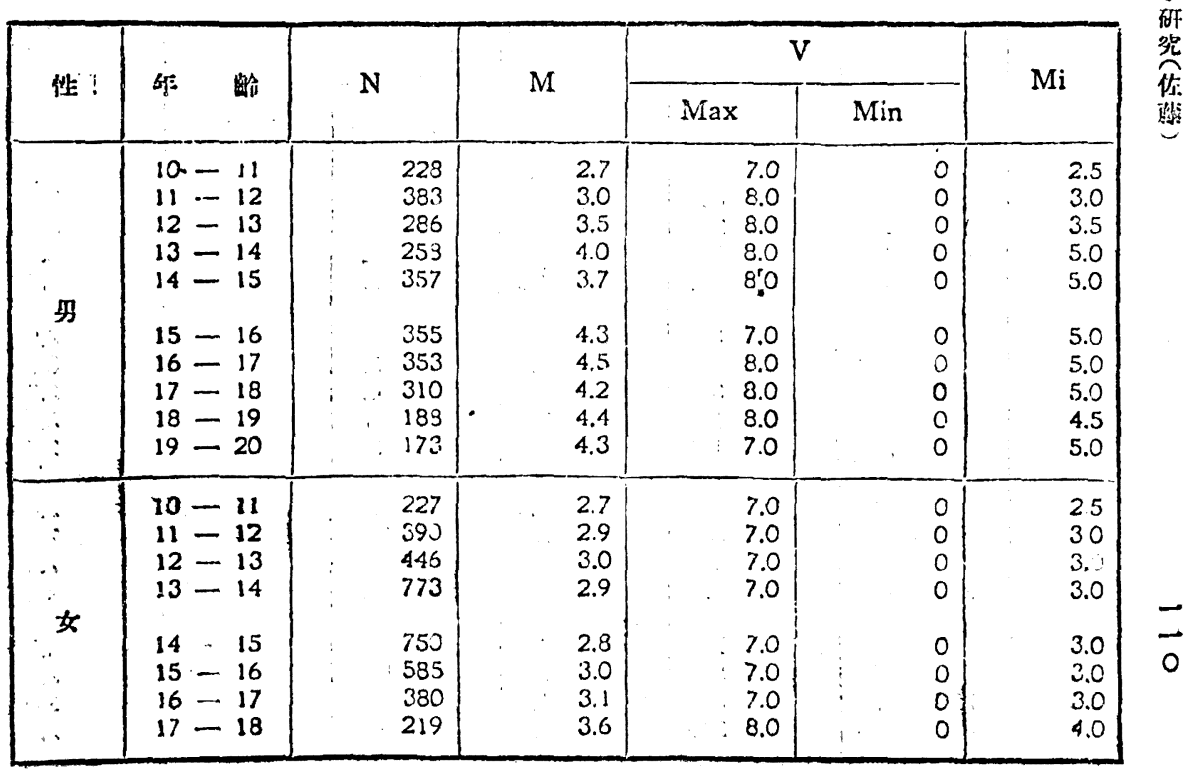




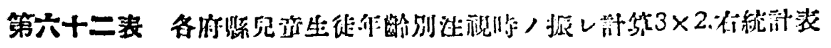

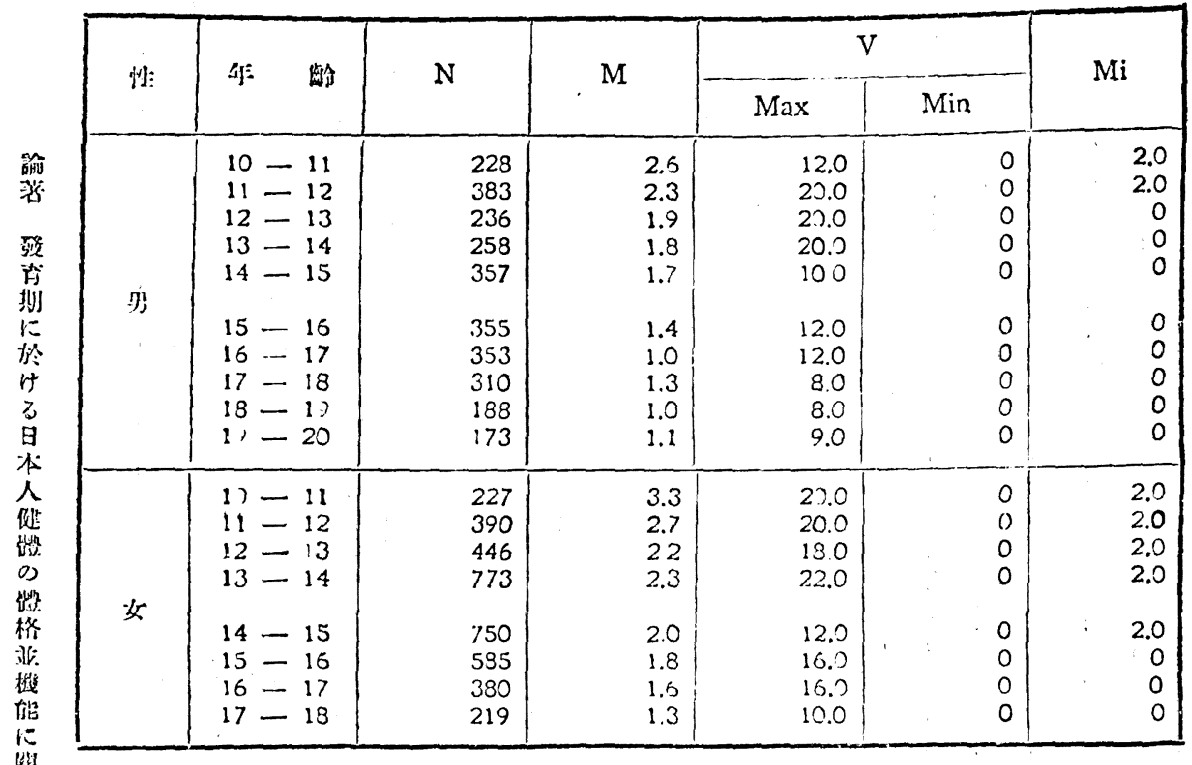

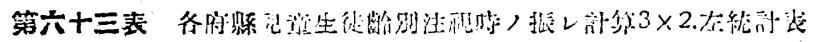

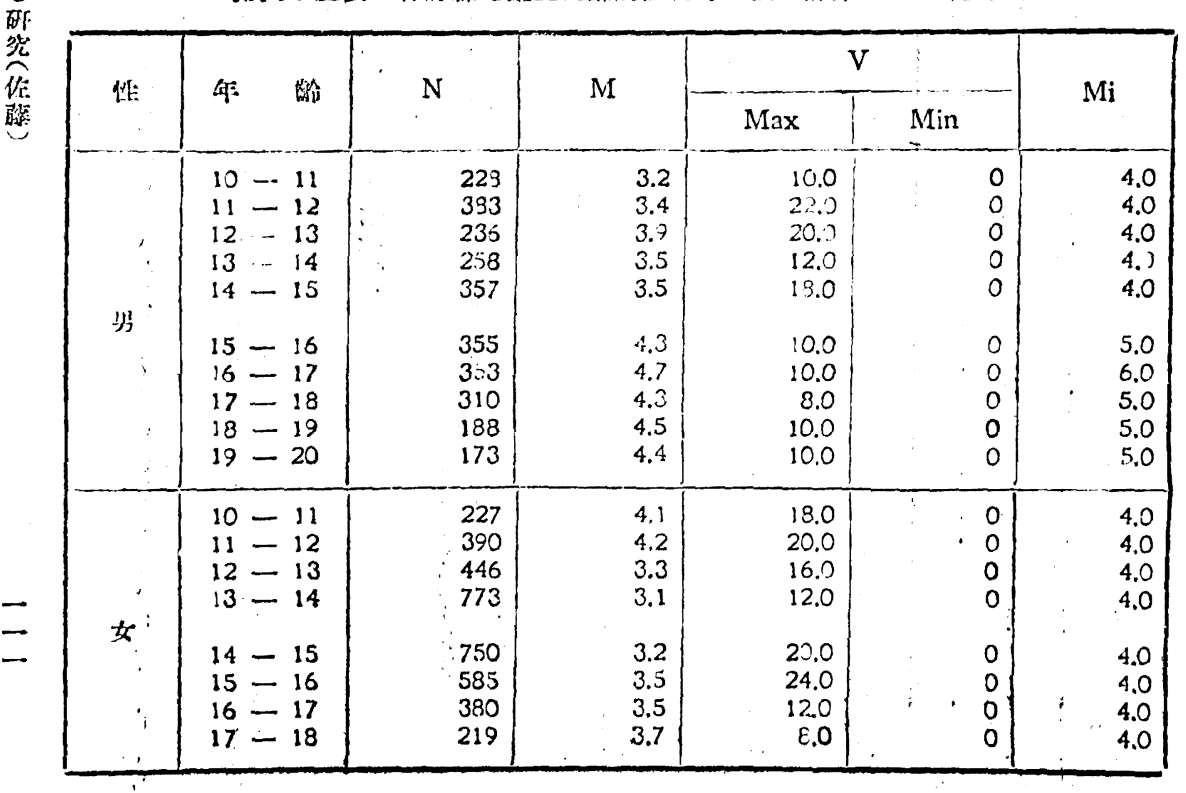




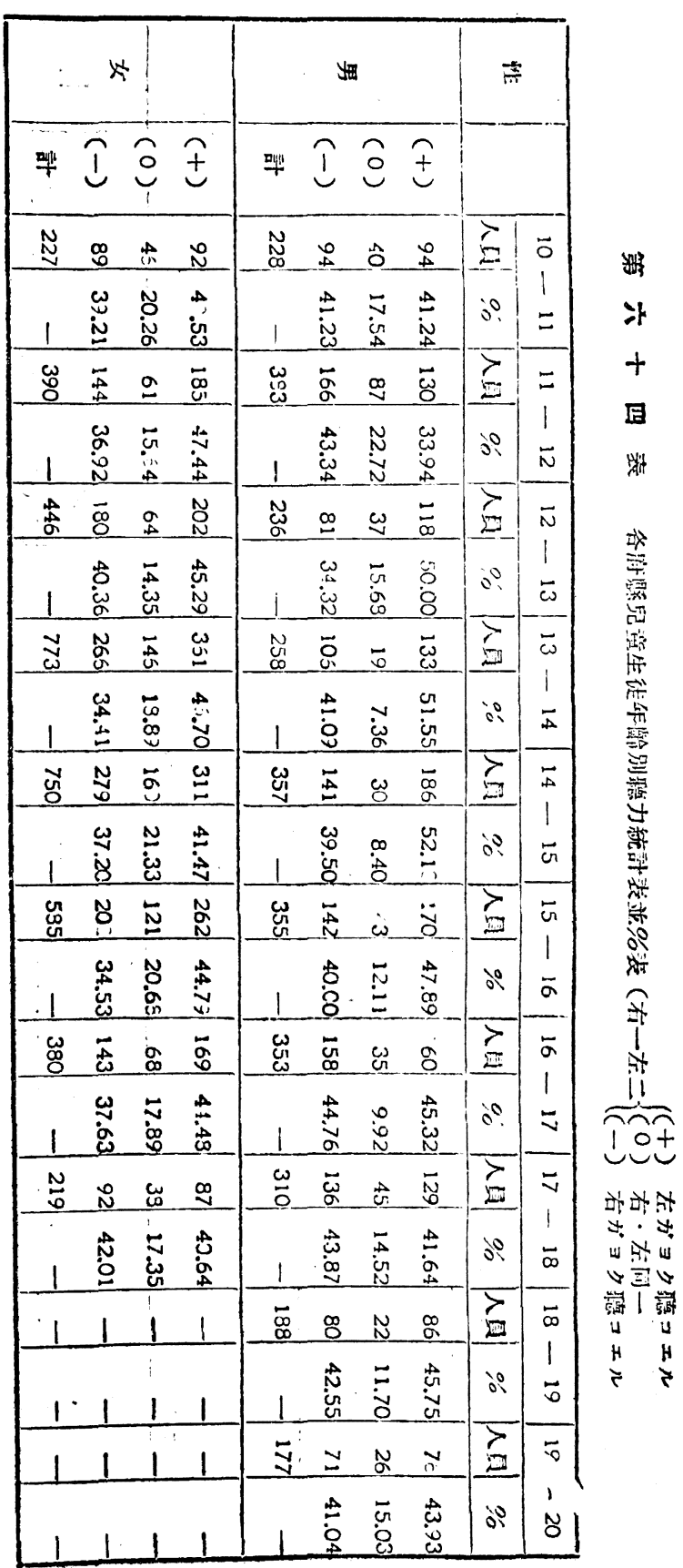

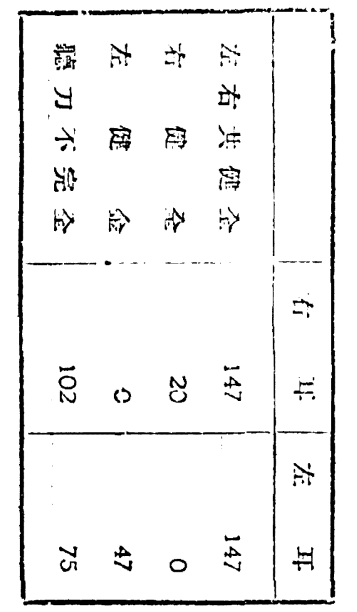

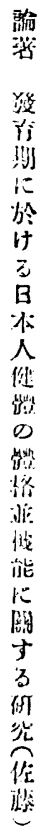

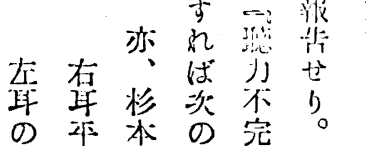

平均比如弪紧

均勘 は

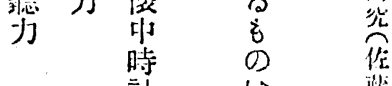

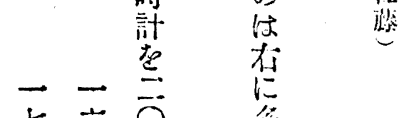

七六

t七 0

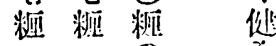

( ) 勧

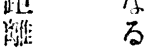

に

粰 估

行

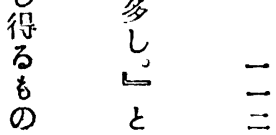

๘

綮而闭

位

$\begin{array}{ll}c & \tau \\ \tau & \text { sili }\end{array}$

就

管 


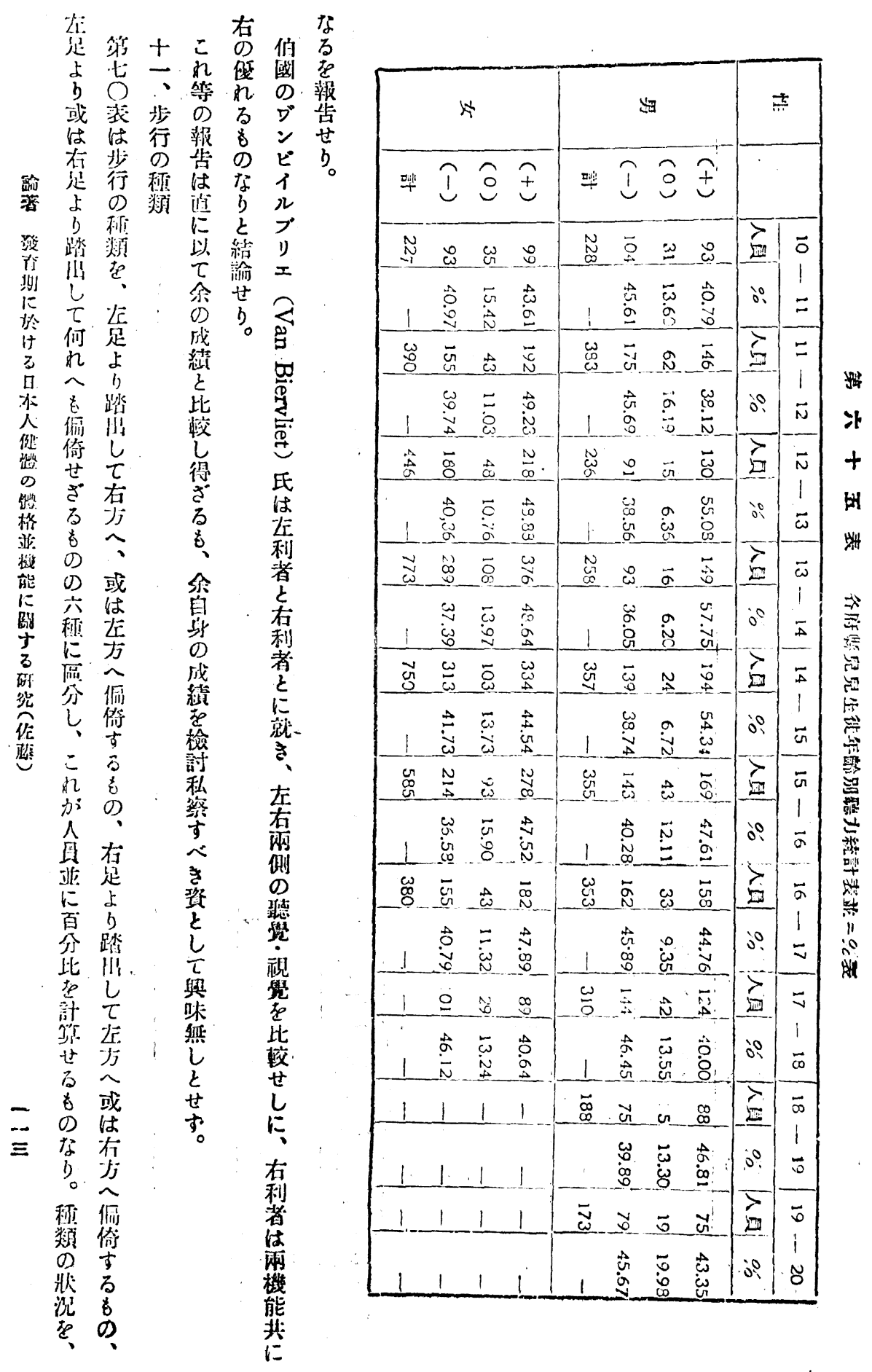


第 六十六表

\begin{tabular}{|c|c|c|c|c|c|c|c|c|c|}
\hline \multicolumn{5}{|c|}{ 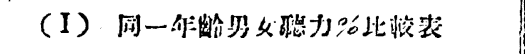 } & \multicolumn{5}{|c|}{ 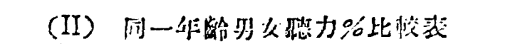 } \\
\hline 作，泟合 & & 果兑 & 女\% \% & 轵\% & 侮: 䍅 & & mo & 女\% & 宾? \\
\hline $10-11$ & $\begin{array}{c}(+) \\
(0) \\
(-)\end{array}$ & $\begin{array}{l}41.23 \\
17.54 \\
41.23\end{array}$ & $\begin{array}{l}40.53 \\
20.26 \\
39.21\end{array}$ & $\begin{array}{l}-0.70 \\
+2.72 \\
-2.02\end{array}$ & $10-11$ & $\begin{array}{l}(+) \\
(0) \\
(-)\end{array}$ & $\begin{array}{l}40.79 \\
13.60 \\
45.61\end{array}$ & $\begin{array}{l}43.61 \\
15.42 \\
40.91\end{array}$ & $\begin{array}{l}+2.82 \\
-1-1.32 \\
-4.64\end{array}$ \\
\hline 11.12 & $\begin{array}{l}(+) \\
(0) \\
(-)\end{array}$ & $\begin{array}{l}33.94 \\
22.72 \\
43.34\end{array}$ & $\begin{array}{l}47.44 \\
15.64 \\
36.92\end{array}$ & $\begin{array}{r}+23.53 \\
-7.08 \\
-6.92\end{array}$ & $11-12$ & $\begin{array}{c}(+) \\
(0 \\
-)\end{array}$ & $\begin{array}{l}38.12 \\
16.19 \\
45.69\end{array}$ & $\begin{array}{l}49.23 \\
11.03 \\
39.79\end{array}$ & $\begin{array}{r}+11.11 \\
-5.16 \\
-5.95\end{array}$ \\
\hline $12-13$ & $\begin{array}{l}(+) \\
(0) \\
(-)\end{array}$ & $\begin{array}{l}50.00 \\
15.68 \\
24.32\end{array}$ & $\begin{array}{l}45.29 \\
14.35 \\
40.36\end{array}$ & $\begin{array}{l}-4.71 \\
-1.33 \\
+6.04\end{array}$ & $12-13$ & $\begin{array}{l}(+1) \\
(0) \\
(-)\end{array}$ & $\begin{array}{r}55.08 \\
6.36 \\
33.56\end{array}$ & $\begin{array}{r}48.88 \\
0.76 \\
40.36\end{array}$ & $\begin{array}{l}-6.20 \\
+4.40 \\
+1.50\end{array}$ \\
\hline $13-14$ & $\begin{array}{l}(+) \\
(0 \\
(-)\end{array}$ & $\begin{array}{r}51.55 \\
7.36 \\
41.09\end{array}$ & $\begin{array}{l}46.70 \\
18.89 \\
34.41\end{array}$ & $\begin{array}{r}-4.85 \\
+11.53 \\
-6.63\end{array}$ & $13-14$ & $\begin{array}{l}(+) \\
(0) \\
(-)\end{array}$ & $\begin{array}{r}37.75 \\
6.20 \\
36.05\end{array}$ & $\begin{array}{l}48.5 \cdot 4 \\
13.97 \\
37.39\end{array}$ & $\begin{array}{l}-9.11 \\
+7.77 \\
+1.34\end{array}$ \\
\hline $14-15$ & $\begin{array}{l}(+) \\
(0) \\
(-)\end{array}$ & $\begin{array}{r}52.10 \\
8.40 \\
39.53\end{array}$ & $\begin{array}{l}41.47 \\
21.33 \\
37.20\end{array}$ & $\begin{array}{r}-10.63 \\
+12.93 \\
-2.30\end{array}$ & $14-15$ & $\begin{array}{l}(\dot{\vec{T}}) \\
(0) \\
(-)\end{array}$ & $\begin{array}{r}54.34 \\
6.72 \\
33.94\end{array}$ & $\begin{array}{l}44.54 \\
13.73 \\
41.73\end{array}$ & $\begin{array}{l}-9.80 \\
+7.11 \\
+2.79\end{array}$ \\
\hline $15-i 6$ & $\begin{array}{l}(+) \\
(0) \\
(-)\end{array}$ & $\begin{array}{r}47.87 \\
2.11 \\
40.00\end{array}$ & $\begin{array}{l}44.79 \\
20.68 \\
34.53\end{array}$ & $\begin{array}{l}-3.10 \\
+8.57 \\
-5.47\end{array}$ & $15-16$ & $\begin{array}{l}(+) \\
(0) \\
(-)\end{array}$ & $\begin{array}{l}47.61 \\
12.11 \\
40.28\end{array}$ & $\begin{array}{l}47.52 \\
15.90 \\
36.58\end{array}$ & $\begin{array}{r}-0.07 \\
+3.79 \\
-3.70\end{array}$ \\
\hline $16-17$ & $\begin{array}{l}(+) \\
(0) \\
(-)\end{array}$ & $\begin{array}{r}45.32 \\
9.92 \\
44.76\end{array}$ & $\begin{array}{l}44.48 \\
17.89 \\
37.63\end{array}$ & $\begin{array}{l}-0.84 \\
+7.97 \\
-7.13\end{array}$ & $16-17$ & $\begin{array}{l}(+) \\
(0) \\
(-)\end{array}$ & $\begin{array}{r}44.76 \\
9.35 \\
45.89\end{array}$ & $\begin{array}{l}47.89 \\
11.22 \\
40.79\end{array}$ & $\begin{array}{l}+3.13 \\
+1.92 \\
-5.10\end{array}$ \\
\hline $17-18$ & $\begin{array}{l}(+) \\
(0) \\
(-)\end{array}$ & $\begin{array}{l}41.61 \\
14.52 \\
43.87\end{array}$ & $\begin{array}{l}40.64 \\
17.35 \\
42.01\end{array}$ & $\begin{array}{l}-0.97 \\
+2.83 \\
-1.86\end{array}$ & $17-18$ & $\begin{array}{l}(+) \\
(0) \\
(-)\end{array}$ & $\begin{array}{l}40.00 \\
13.55 \\
46.45\end{array}$ & $\begin{array}{l}40.64 \\
13.24 \\
46.12\end{array}$ & $\begin{array}{l}+0.64 \\
-0.31 \\
-0.33\end{array}$ \\
\hline $18-10$ & $\begin{array}{l}(+) \\
(0) \\
(-)\end{array}$ & $\begin{array}{l}45.75 \\
11.70 \\
42.55\end{array}$ & $\overline{-}$ & $\bar{z}$ & $18-19$ & $\begin{array}{l}(+) \\
(0) \\
(-)\end{array}$ & $\begin{array}{l}46.81 \\
13.30 \\
39.87\end{array}$ & $\bar{z}$ & $\overline{-}$ \\
\hline $19-20$ & $\begin{array}{l}(+) \\
(0) \\
(-)\end{array}$ & $\begin{array}{l}43.93 \\
15.03 \\
41.04\end{array}$ & $\bar{z}$ & $\bar{z}$ & $19-20$ & $\begin{array}{l}(+) \\
(0) \\
(-)\end{array}$ & $\begin{array}{l}43.53 \\
10.98 \\
45.67\end{array}$ & $\bar{z}$ & $\bar{z}$ \\
\hline
\end{tabular}




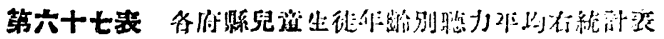

\begin{tabular}{|c|r|r|r|r|r|r|}
\hline & & & & \\
\end{tabular}

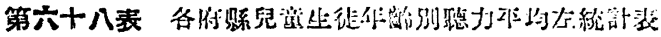

\begin{tabular}{|c|c|c|c|c|c|c|}
\hline \multirow{2}{*}{ 吽: } & \multirow{2}{*}{ 行: 敨 } & \multirow{2}{*}{$N$} & \multirow{2}{*}{$M$} & \multicolumn{2}{|c|}{ V } & \multirow{2}{*}{$\mathrm{Mi}$} \\
\hline & & & & Max & Min & \\
\hline 男 & $\begin{array}{l}10-11 \\
11=12 \\
12=13 \\
13=14 \\
14=15 \\
15-16 \\
16=17 \\
17=18 \\
18=19 \\
19=20\end{array}$ & $\begin{array}{l}228 \\
383 \\
235 \\
258 \\
357 \\
355 \\
353 \\
310 \\
188 \\
173\end{array}$ & $\begin{array}{l}27.06 \\
28.76 \\
23.93 \\
3012 \\
30.07 \\
\\
22.49 \\
20.25 \\
19.54 \\
18.34 \\
18.02\end{array}$ & $\begin{array}{l}75.5 \\
71.0 \\
80.5 \\
95.5 \\
92.0 \\
\\
80.0 \\
64.5 \\
445 \\
44.5 \\
90.5\end{array}$ & \begin{tabular}{r|}
10.0 \\
10.5 \\
7.5 \\
8.5 \\
10.0 \\
10.5 \\
9.5 \\
9.5 \\
9.5 \\
10,5
\end{tabular} & $\begin{array}{l}26.0 \\
30.5 \\
21.5 \\
24.5 \\
23.5 \\
\\
20.5 \\
18.5 \\
18.5 \\
17.0 \\
16.5\end{array}$ \\
\hline \multirow{2}{*}{ 女 } & $\begin{array}{l}10-11 \\
11-12 \\
12-13 \\
13-14\end{array}$ & $\begin{array}{l}227 \\
390 \\
446 \\
773\end{array}$ & $\begin{array}{l}26.66 \\
26.86 \\
23.34 \\
30.38\end{array}$ & $\begin{array}{l}61.0 \\
63.5 \\
95.5 \\
93.0\end{array}$ & $\begin{array}{r}10.5 \\
7.5 \\
7.5 \\
0\end{array}$ & $\begin{array}{l}25.5 \\
25.5 \\
26.0 \\
26.0\end{array}$ \\
\hline & $\begin{array}{l}14-15 \\
15-16 \\
16-17 \\
17-18\end{array}$ & $\begin{array}{l}750 \\
585 \\
380 \\
219\end{array}$ & $\begin{array}{l}31.33 \\
26.46 \\
25.96 \\
22.29\end{array}$ & $\begin{array}{l}92.5 \\
90.5 \\
50.5 \\
51.0\end{array}$ & $\begin{array}{r}0 \\
2.5 \\
10.5 \\
5.5\end{array}$ & $\begin{array}{l}26.0 \\
25.5 \\
26.0 \\
21.0\end{array}$ \\
\hline
\end{tabular}


第穴十九婊

\begin{tabular}{|c|c|c|c|c|c|c|}
\hline \multirow{2}{*}{ 年 䍉 } & \multicolumn{2}{|c|}{ M } & \multicolumn{2}{|c|}{$\mathrm{Mi}$} & \multicolumn{2}{|c|}{ Mo } \\
\hline & 右 & 左: & 阵 & t: & 有 & tr: \\
\hline $7-8$ & 49.1 & 46.0 & 45.0 & 31.4 & 47.7 & 41.1 \\
\hline $8-9$ & 27.2 & 23.1 & 26.4 & 20.6 & 26.9 & 22.3 \\
\hline $9-10$ & 27.7 & 25.6 & 25.6 & 20.4 & 27.0 & 23.9 \\
\hline $10-11$ & 26. 3 & 25.1 & 20.5 & 20.4 & 24.4 & 23.6 \\
\hline $11-12$ & 15.4 & 23.7 & 15.4 & 12.4 & 15.4 & 10.3 \\
\hline $12-13$ & 15.6 & 13.9 & 14.0 & 10.9 & 15.1 & 12.9 \\
\hline
\end{tabular}

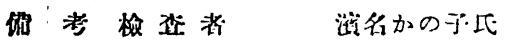

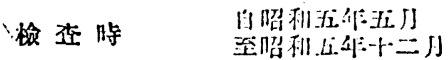

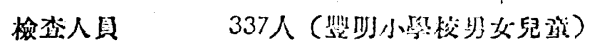

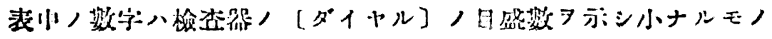

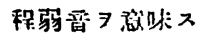

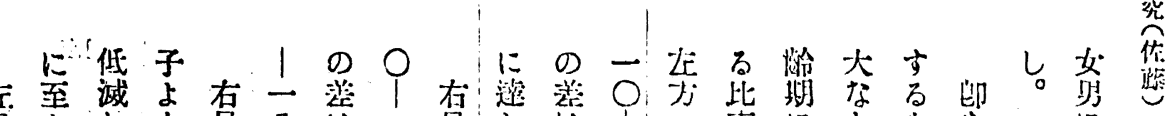

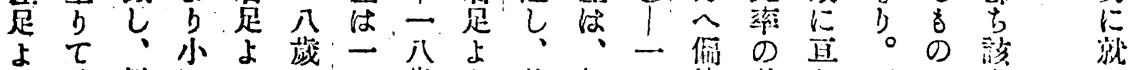

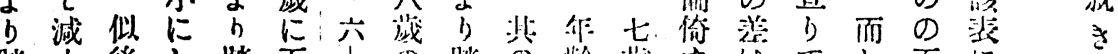

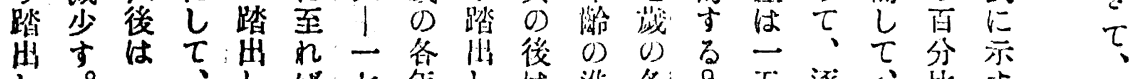

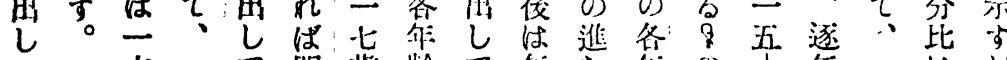

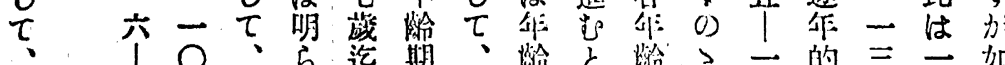

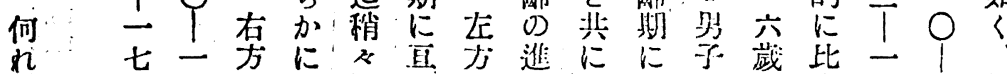

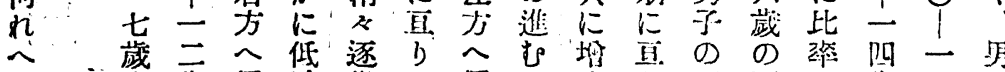

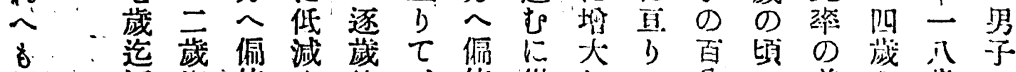

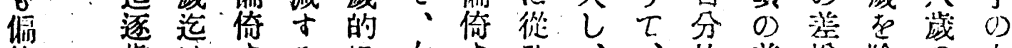

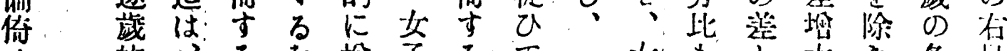

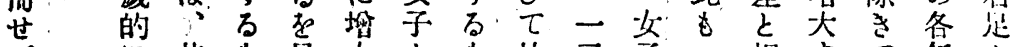

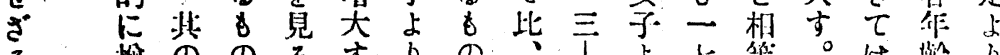

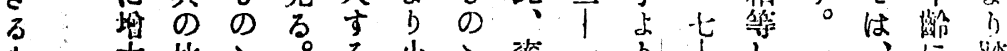

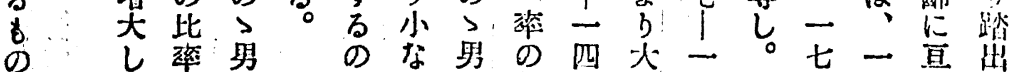

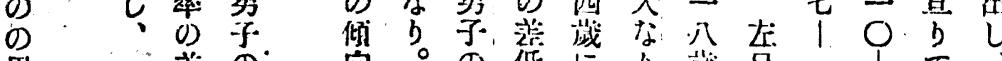

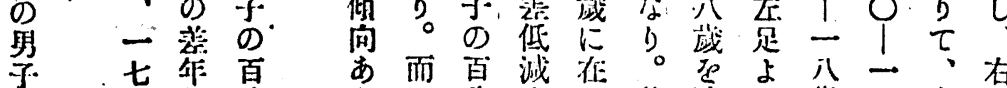

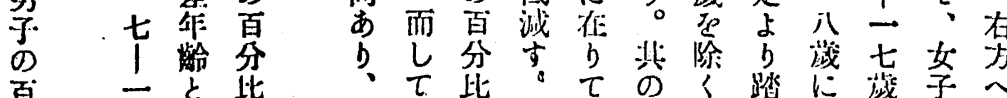

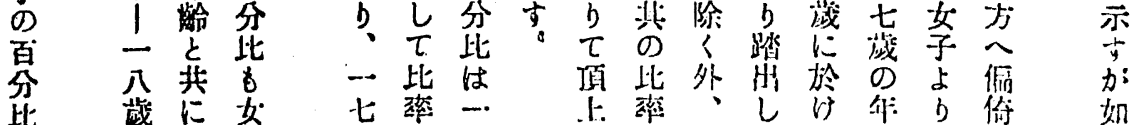

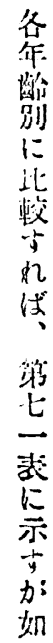




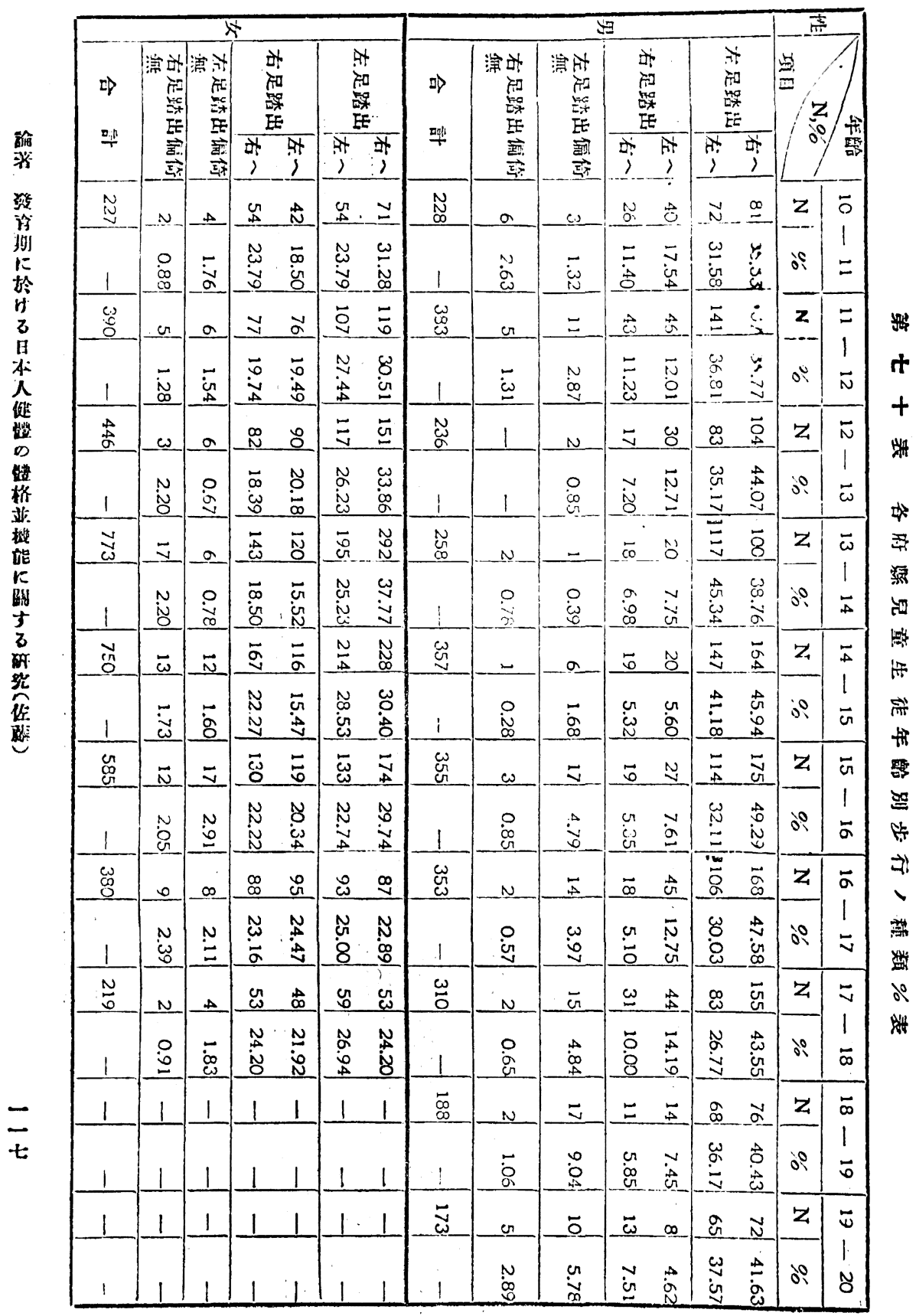




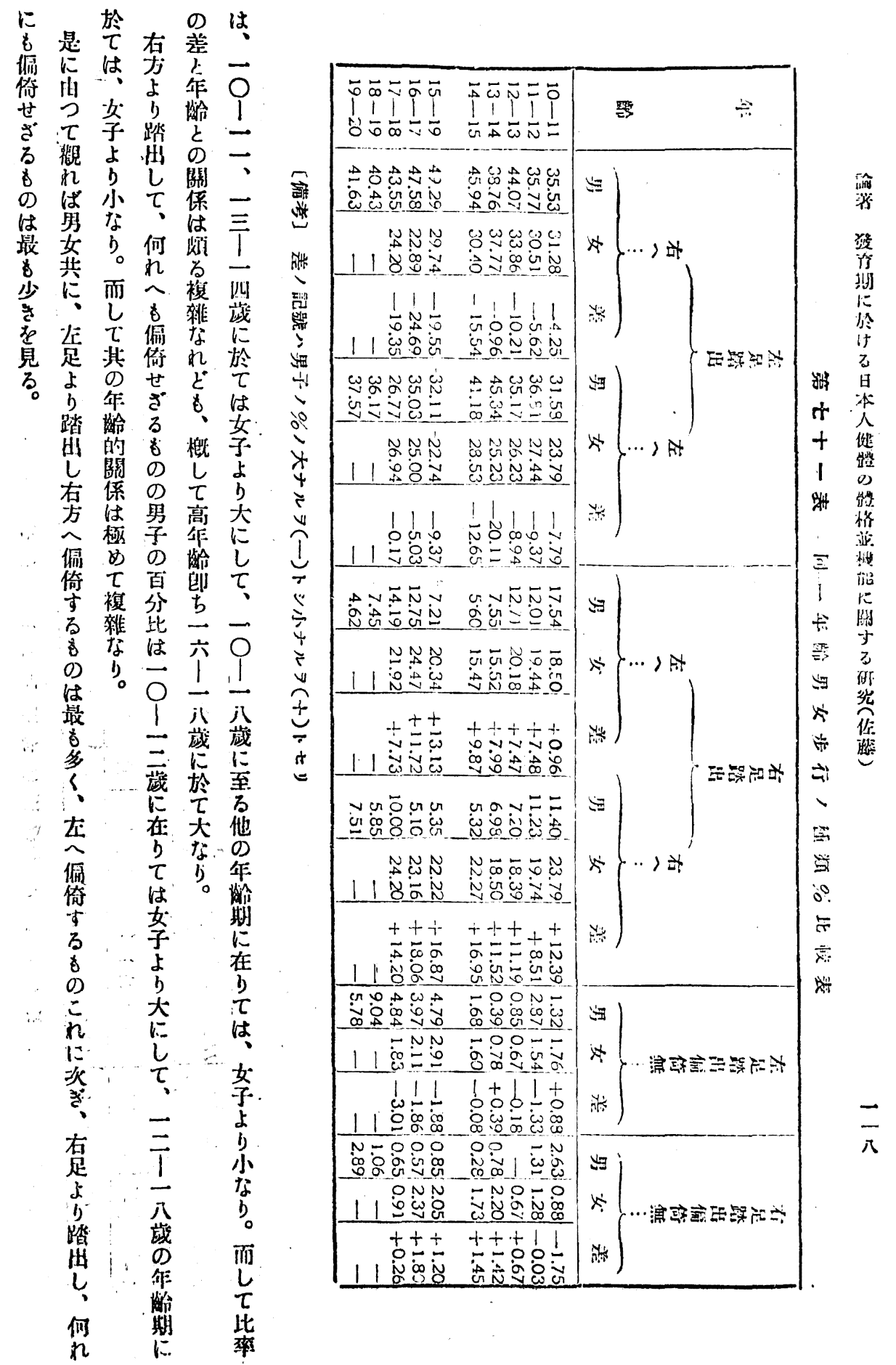




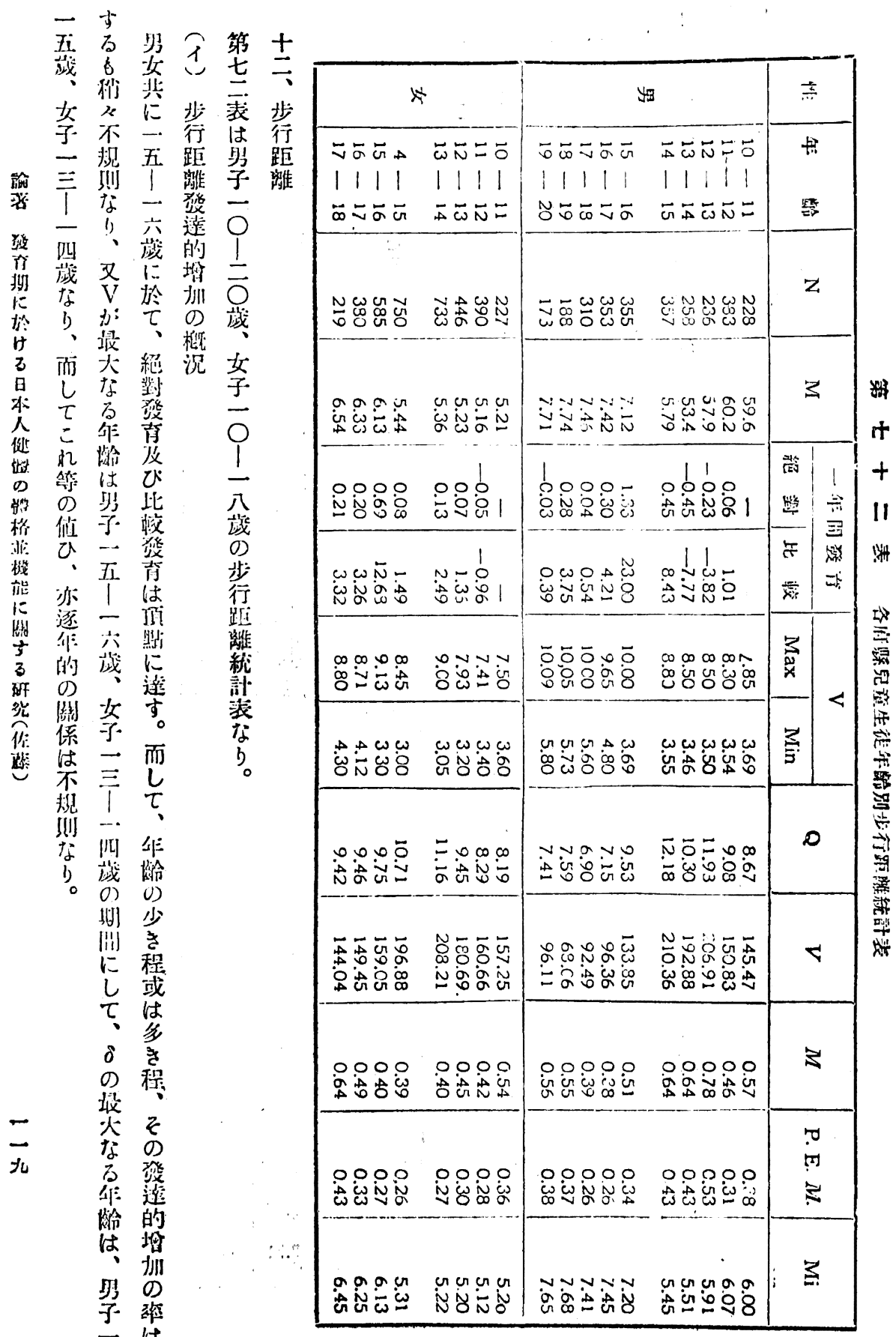




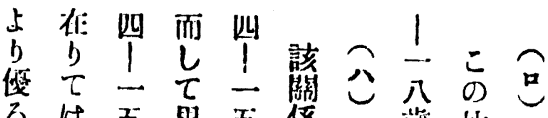

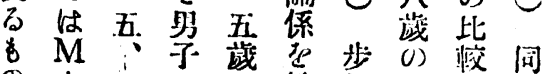

の $2-\frac{5}{-}$ 悱行期の-

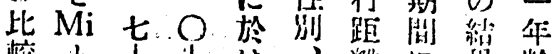

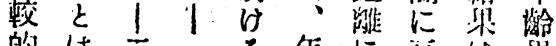

的は二- - 尔に正は男

多全

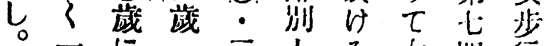

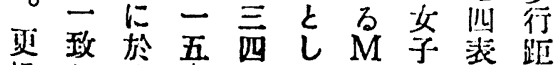

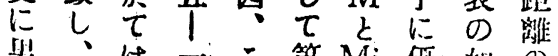

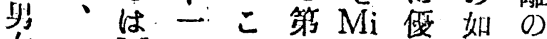

女

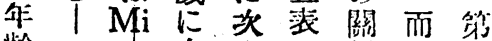

峆 - 在に゙に俰し

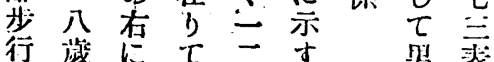

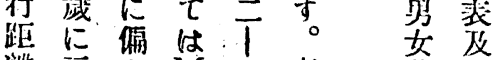

跳亘少 $\mathrm{M}$ - 表其び

分りるは四にに徆

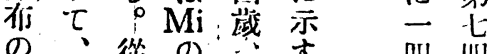

の、從 0 品 す 叫叮

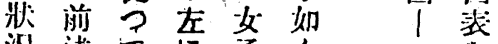

测速

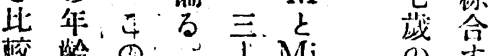

较 謧 0 T Mi O)

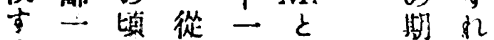

る五に琶は間ば

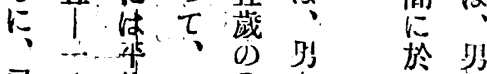

已齐掬こ 0 炎等

非战

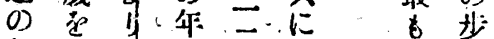

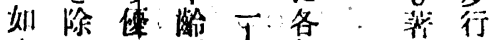

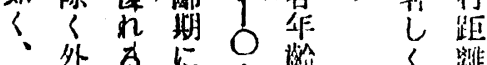

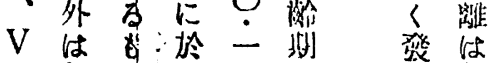

の们 手江九に。

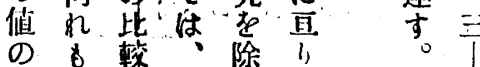

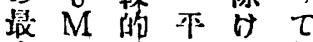

大は多、均は相

な M! U。他接

万の 0 は 近

年在次劣何岂

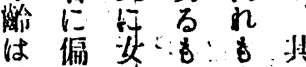

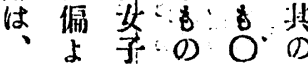

琞方禾此官最

子。五整的高

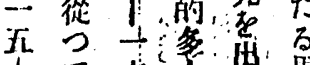

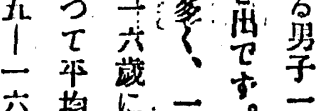

\begin{tabular}{|c|c|c|c|c|}
\hline 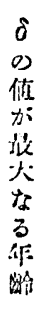 & 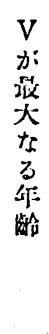 & 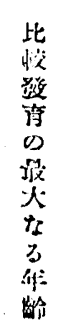 & 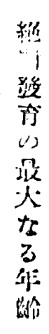 & 绱 \\
\hline$\frac{\vec{\square}}{\frac{1}{x}}$ & $\frac{\bar{x}}{\bar{x}}$ & $\begin{array}{l}\overline{\bar{z}} \\
\frac{1}{\bar{x}}\end{array}$ & $\frac{\vec{j}}{x}$ & $-j$ \\
\hline 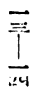 & $\frac{\bar{\Xi}}{\frac{1}{k u}}$ & $\frac{\equiv}{\frac{\equiv}{x}}$ & $\frac{\bar{\pi}}{\frac{1}{x}}$ & 女 \\
\hline
\end{tabular}

雚 七十四表

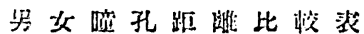

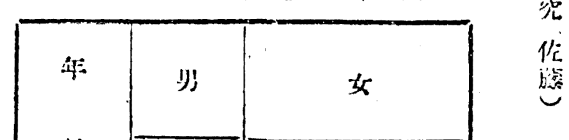

$\overline{0}$ 


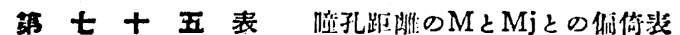

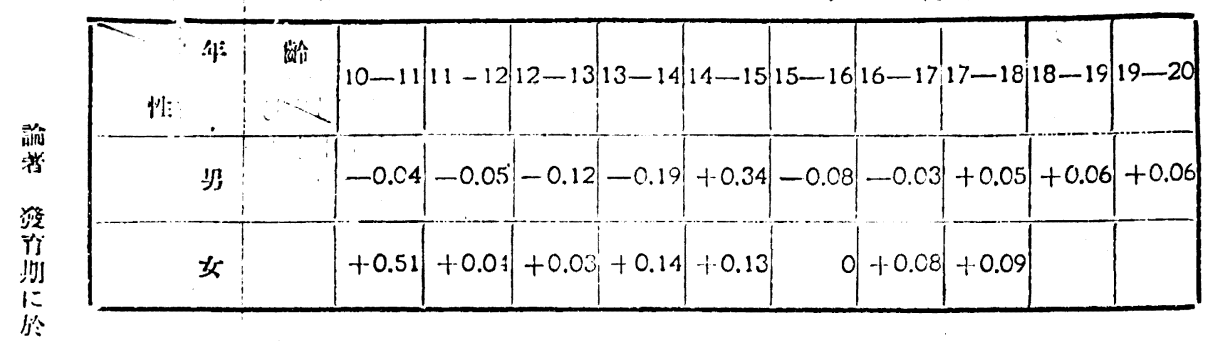

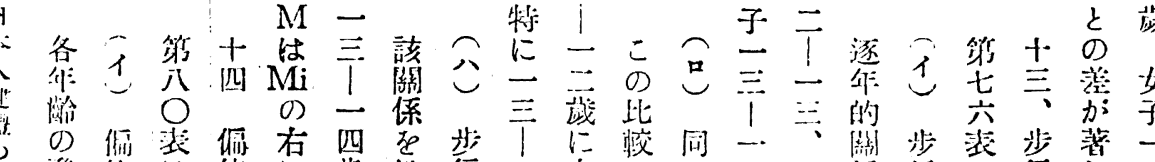

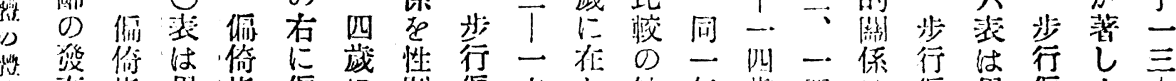

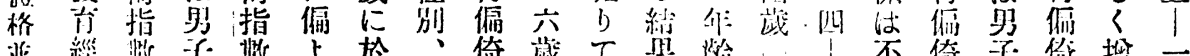

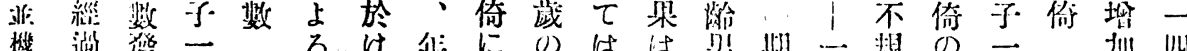

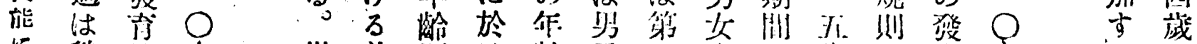

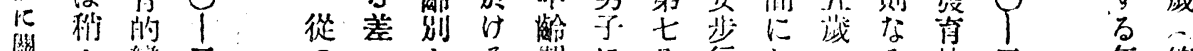

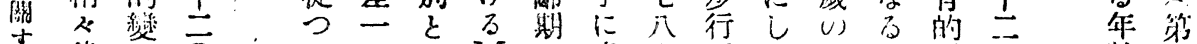

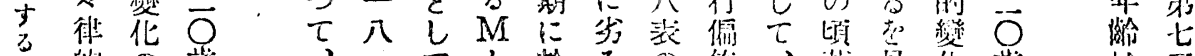

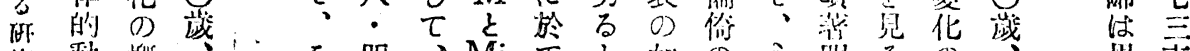

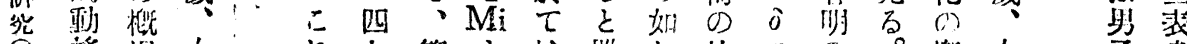

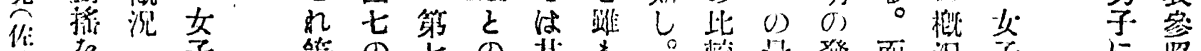

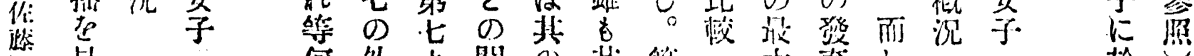

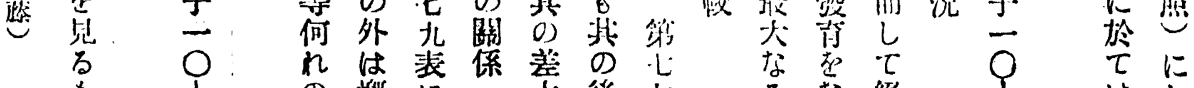

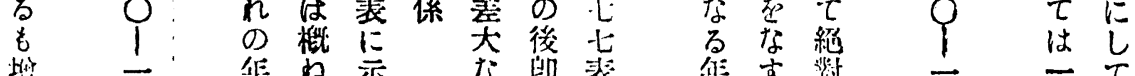

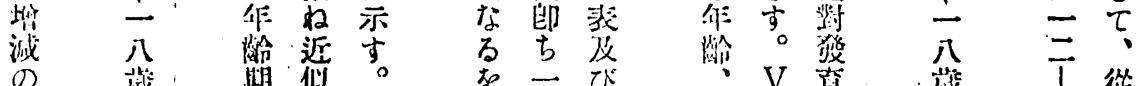

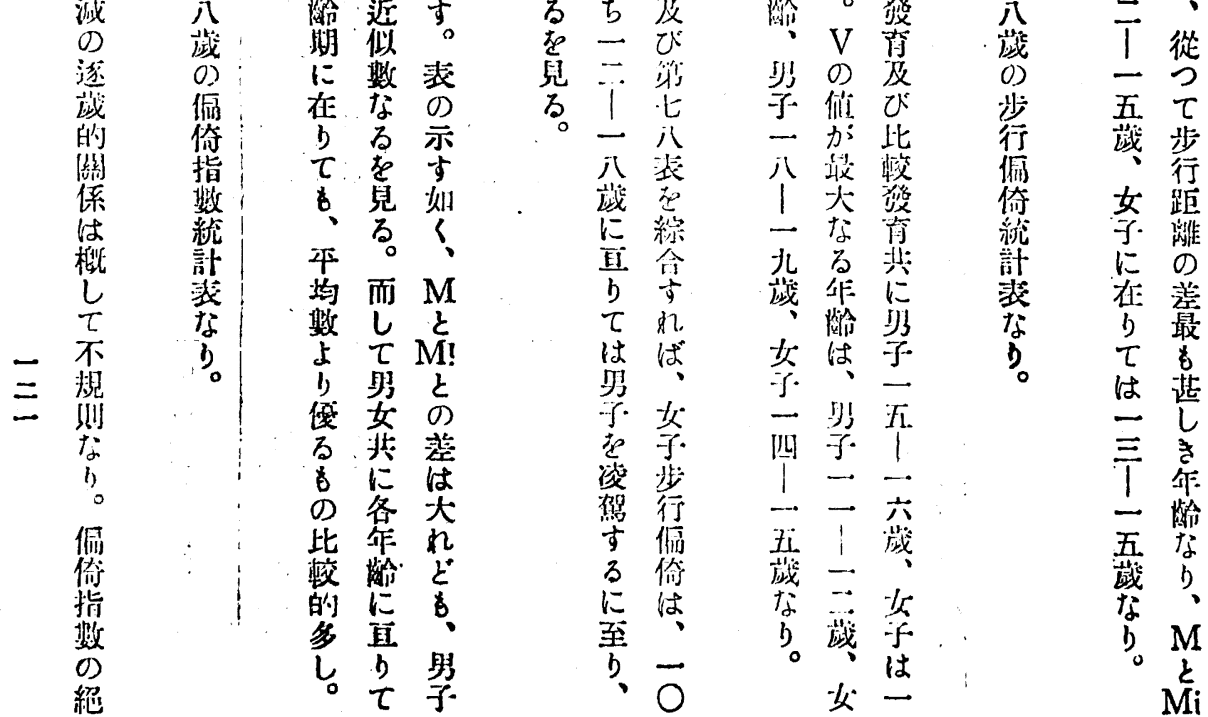




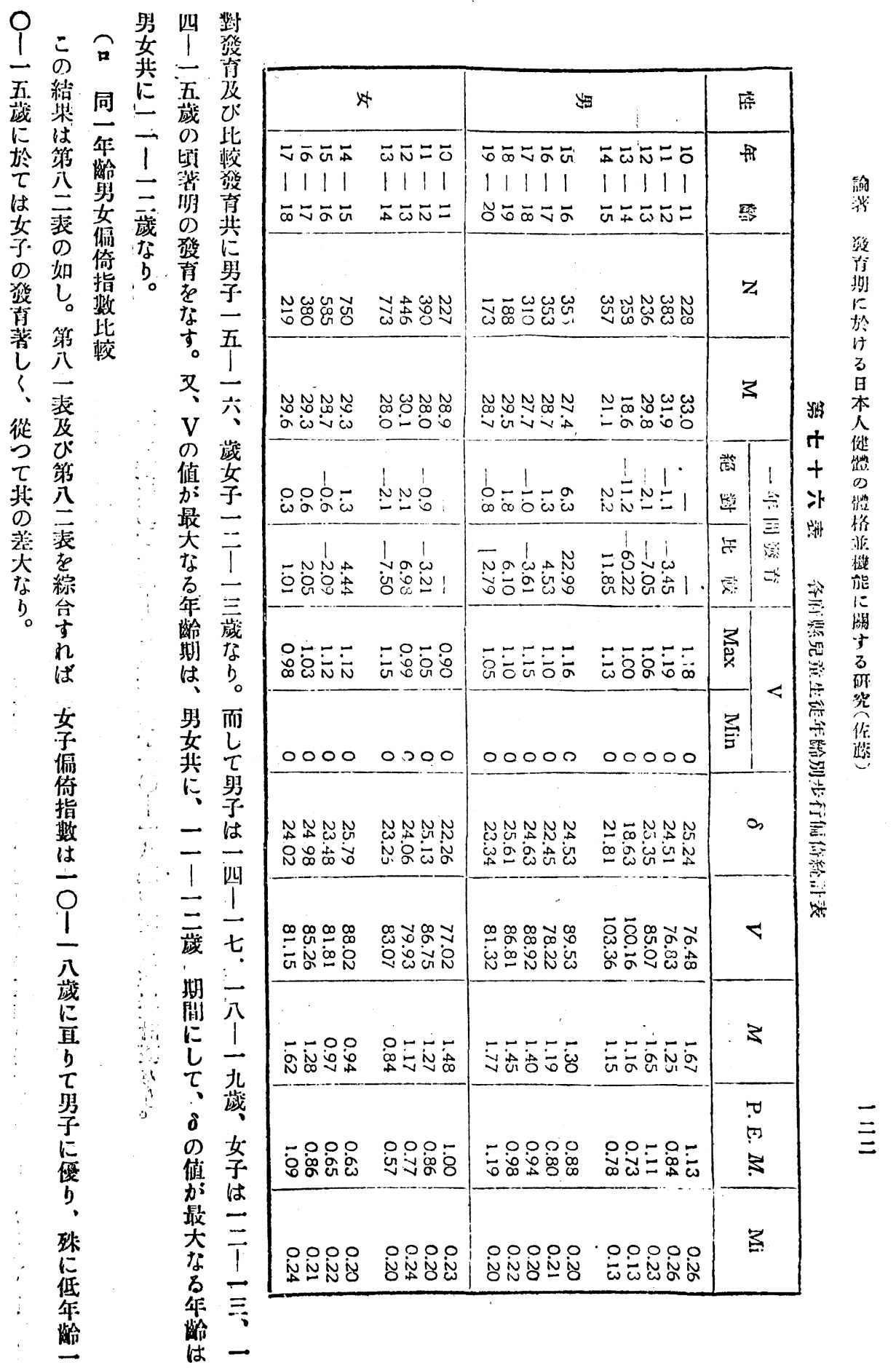




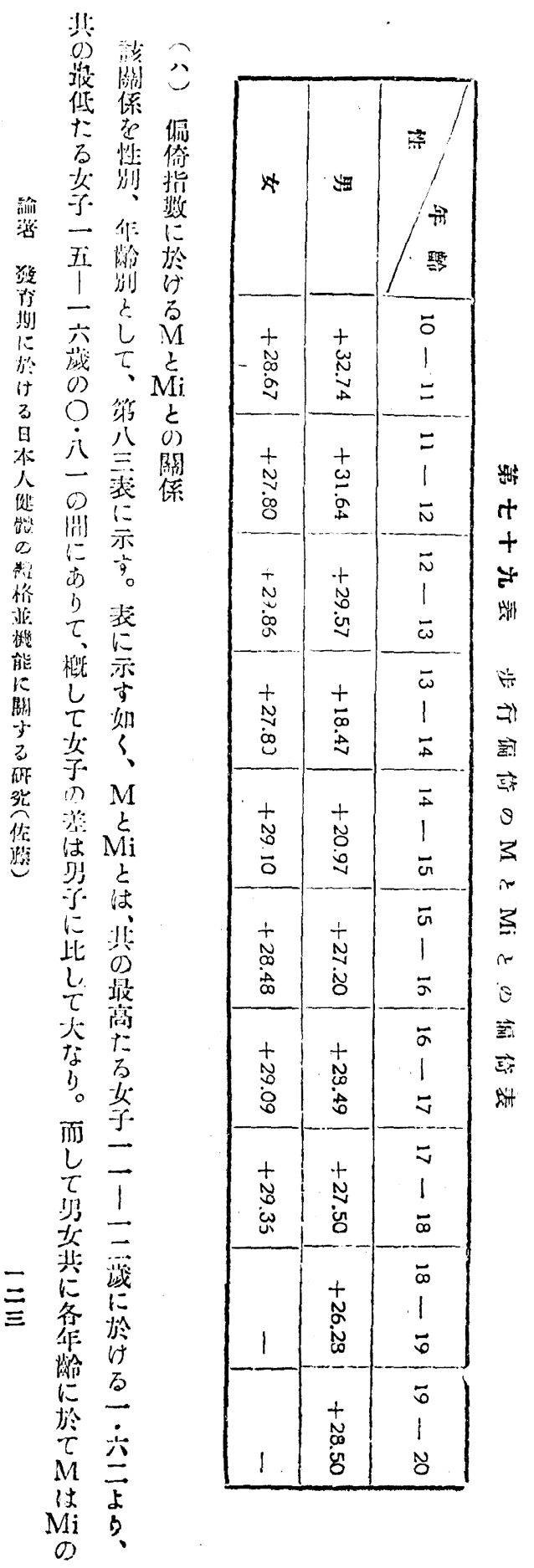

第七十七核

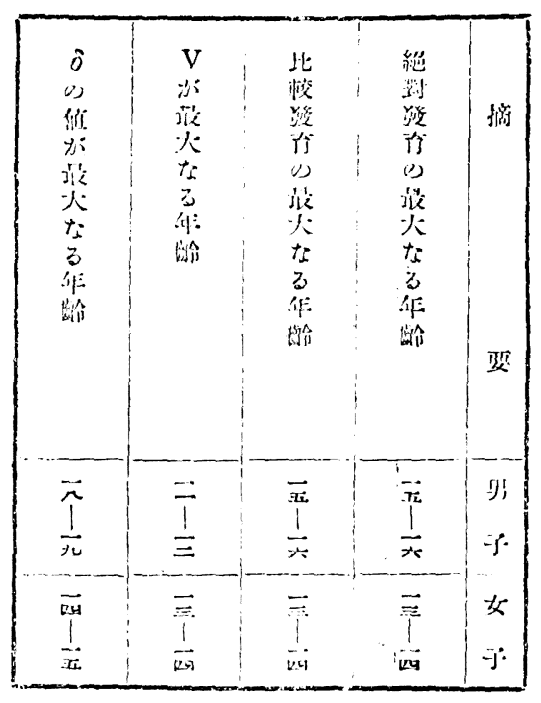

第七十八表

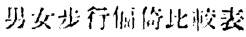

\begin{tabular}{|c|c|c|c|}
\hline 作 & yi & \multicolumn{2}{|c|}{ 女 } \\
\hline $10-11$ & 33.0 & 28.9 & -4.1 \\
$11-12$ & 31.9 & 28.0 & +3.9 \\
$12-13$ & 29.8 & 30.1 & +0.3 \\
$13-14$ & 18.6 & 29.0 & +9.4 \\
$14-15$ & 21.1 & 29.3 & +8.2 \\
$15-16$ & 27.4 & 28.7 & +1.3 \\
$16-17$ & 28.7 & 29.3 & +0.6 \\
$17-18$ & 27.7 & 29.6 & +1.9 \\
$13-19$ & 29.5 & & \\
$19-20$ & 28.7 & & \\
\hline
\end{tabular}




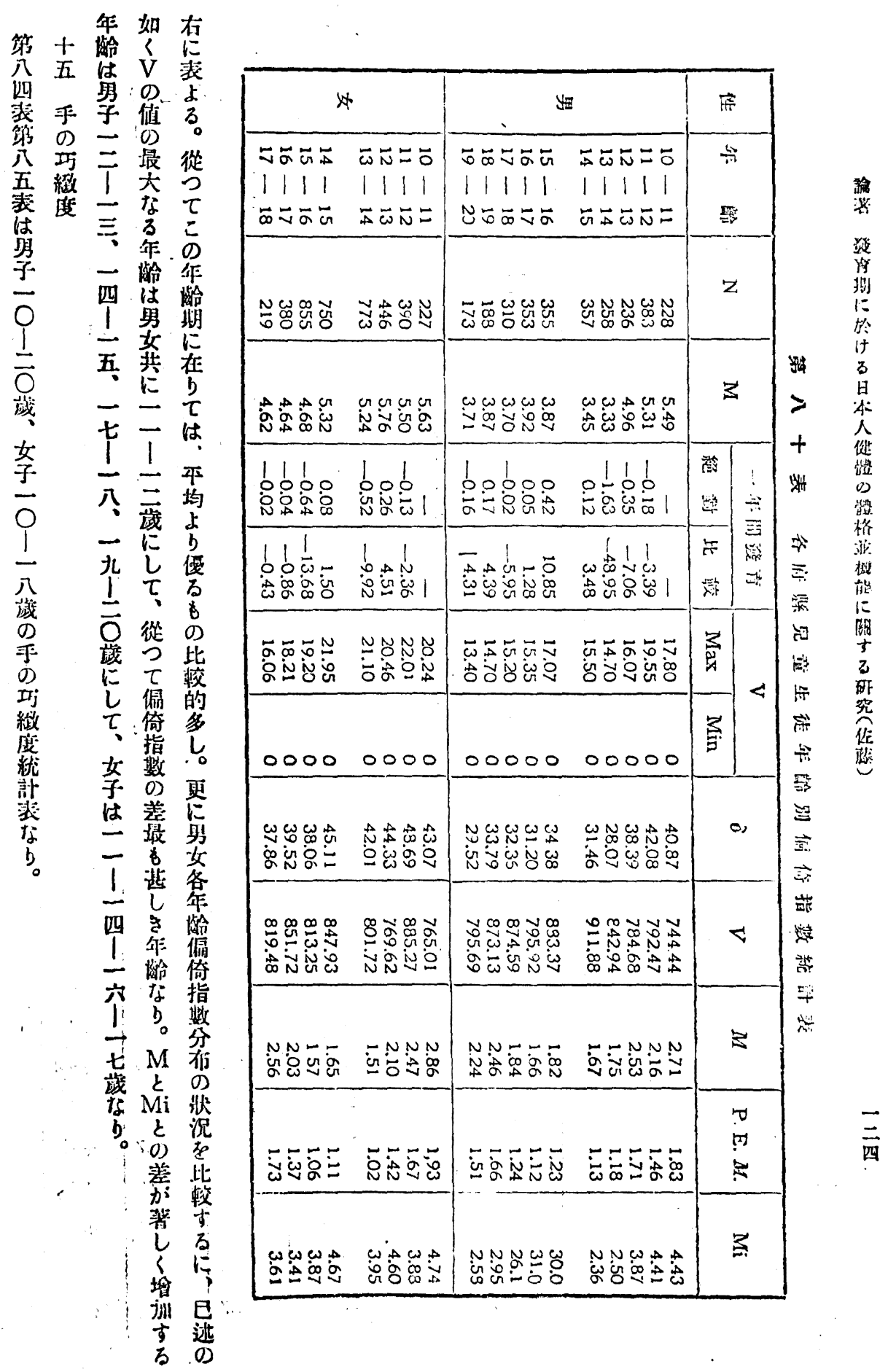




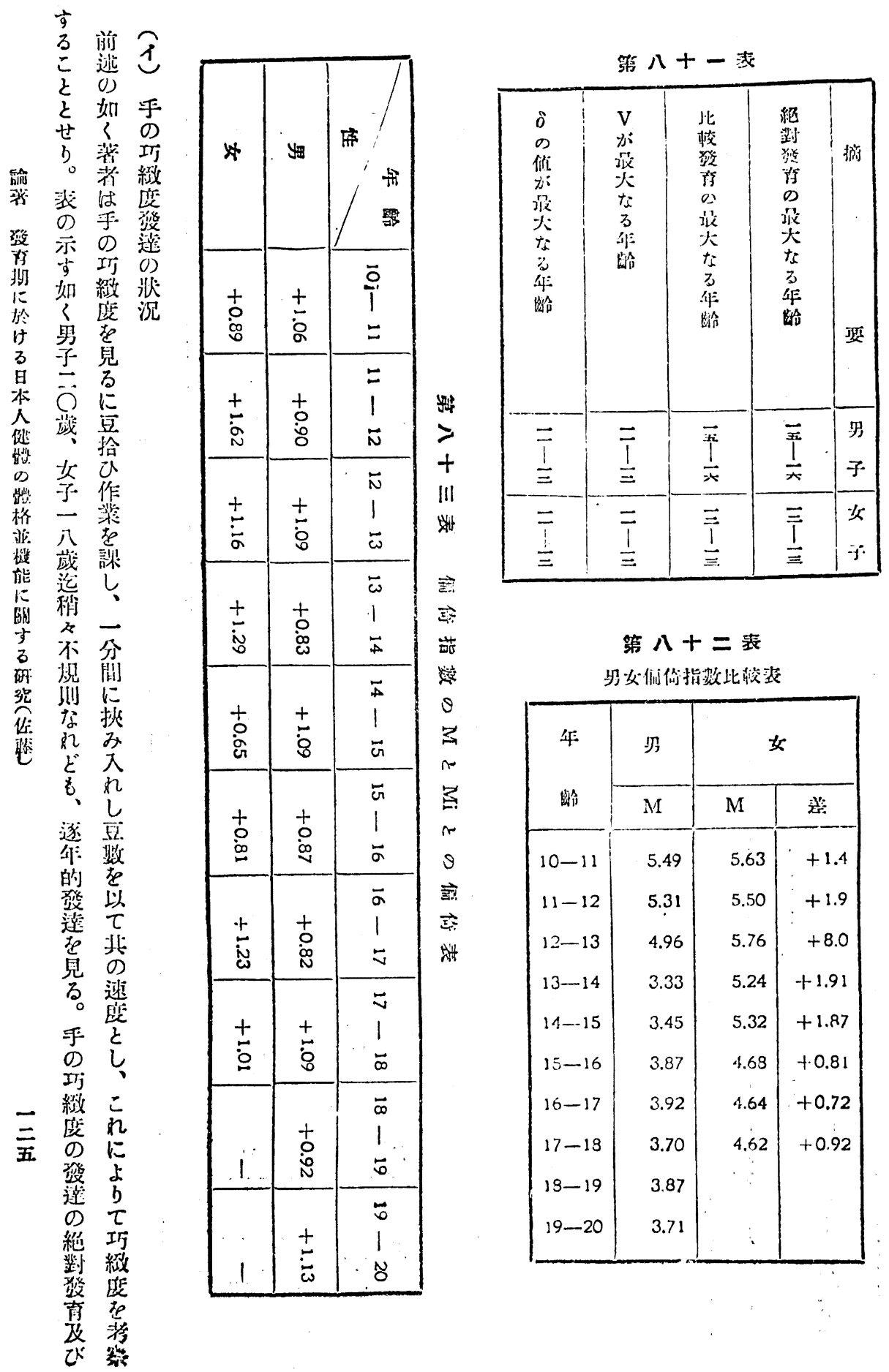




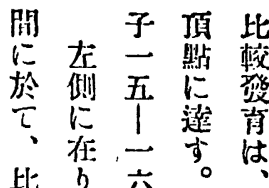

比交立藏右

發は、し 侧

充尖不

は䋓子男在

一對 一子小

三發三にて

I. 育 I 於は

叫比四は列

藏梖战一子。

に沙の六は

在青期 1-

b共間一五.

最羿し战上

大桨灭六

なに: 女藏

万於 0 子

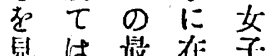

万一大

$\mathrm{V}$ 五な育

の年年立

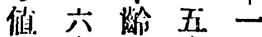

加藏生厂八

最最狸一荿

大大子六迄

なに一藏稍

る ᄂ 三 0

は只留 不

桀女四萌想

は李歳のな

一 は 㷋れ

五絶女達

1 對禾哆

六筒六方逐

荿は中 10 年

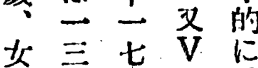

子丁盛 の堺

俚一值加

一四 b㔔し

六一。最こ

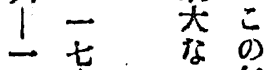

声年年

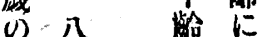

期旅 期至

間のはn

\begin{tabular}{|c|c|c|c|c|c|}
\hline \multicolumn{2}{|c|}{$x$} & \multicolumn{2}{|c|}{$\leq$} & $\overrightarrow{\mathrm{n}}$ & \\
\hline ジず & $\bar{\omega} \bar{N}=\check{0}$ & ららこのた & 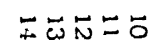 & $\doteqdot$ & \\
\hline 1111 & 1111 & 11111 & 11111 & & \\
\hline らこここ & ムらえこ & 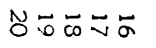 & 鹃岕心 & 黑 & \\
\hline 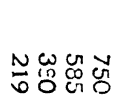 & $\begin{array}{l}V \\
\omega \\
\omega\end{array}$ & 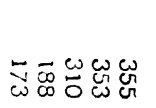 & 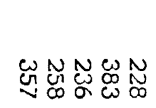 & $z$ & \\
\hline 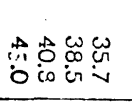 & 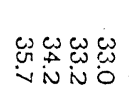 & 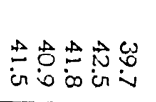 & 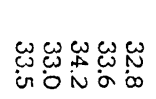 & $\geq$ & \\
\hline 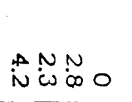 & $\stackrel{N}{i}=\dot{N}$ & 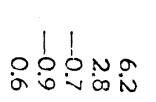 & 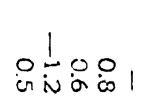 & $\begin{array}{l}\text { 警 } \\
\text { 紫 }\end{array}$ & 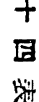 \\
\hline 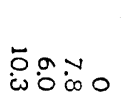 & 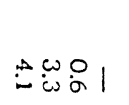 & 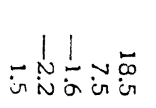 & 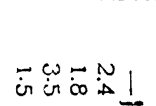 & 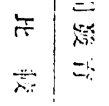 & 谱 \\
\hline 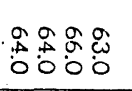 & 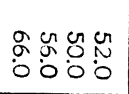 & 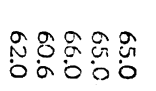 & 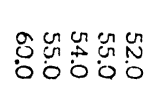 & $\underset{3}{3}$ & 勧 \\
\hline 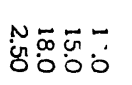 & 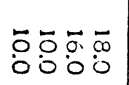 & 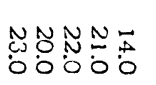 & 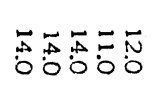 & 罙 & 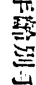 \\
\hline 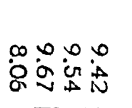 & 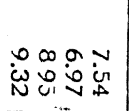 & 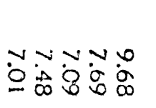 & 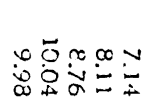 & 0 , & 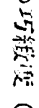 \\
\hline 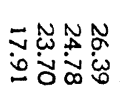 & 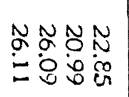 & 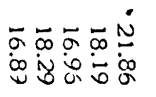 & 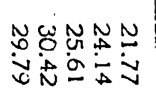 & $\nabla$ & 答 \\
\hline 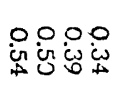 & 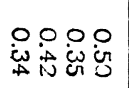 & 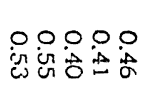 & 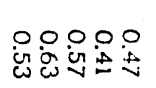 & 娄 & \\
\hline$\circ$ & 우 & o & 0.000 & 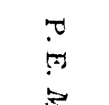 & \\
\hline
\end{tabular}

に期

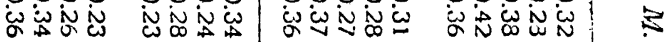

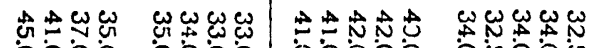

3. 


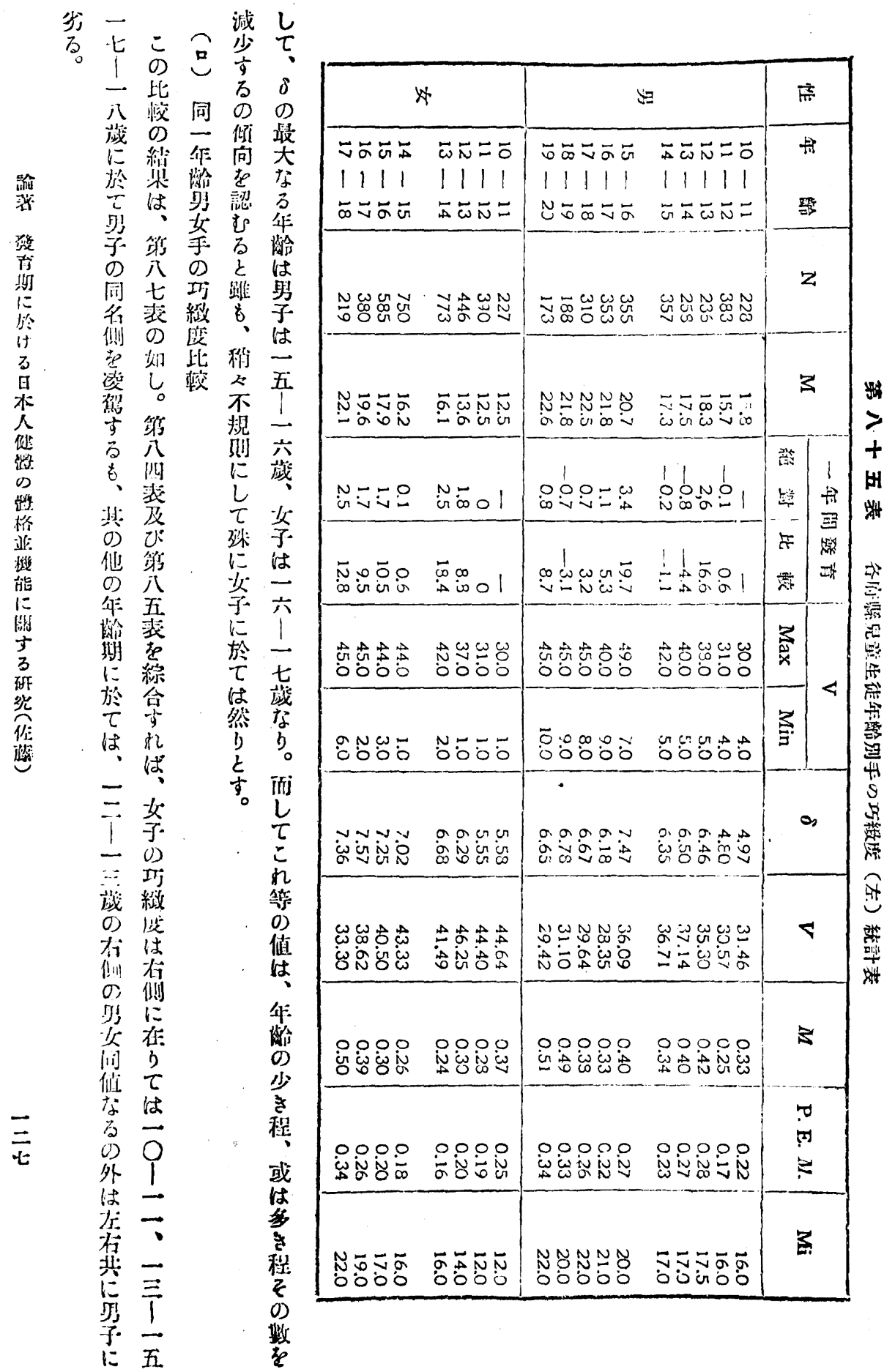




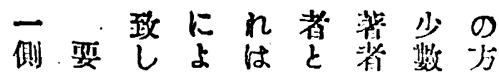

の卞 V b 著䠊のな法

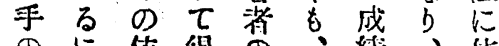

の值得の、維、依

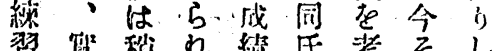

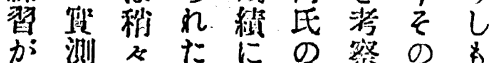

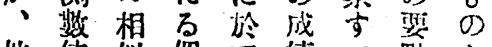

他做似假宁縝心默々

侧のた然はは凅縆て

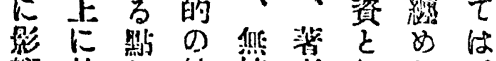

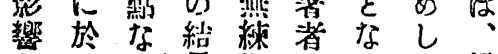

してし果習のすす橙 はとな死をを㥓

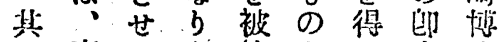

の直すと檢よべら士

能接。想者名し籐の

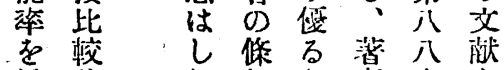

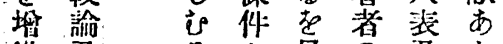

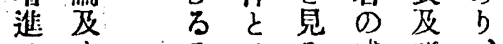

せす气せる成び、

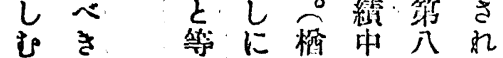

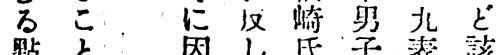

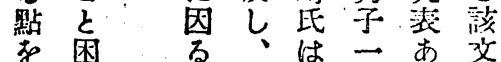

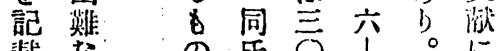

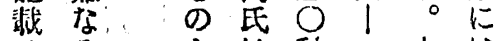

世る。秒一林蛙

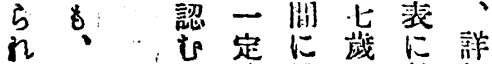

管八十六表

\begin{tabular}{|c|c|c|c|c|c|}
\hline 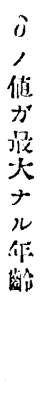 & 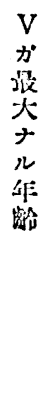 & 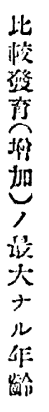 & 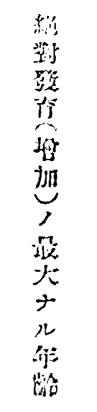 & \multicolumn{2}{|c|}{ 饬 } \\
\hline$\frac{\bar{\Xi}}{\overline{1}}$ & $\frac{\overrightarrow{7}}{1}$ & $\frac{\overline{7}}{\bar{x}}$ & $\frac{\vec{F}}{=}$ & 不 & 约 \\
\hline $\begin{array}{l}\bar{\pi} \\
\frac{1}{夭}\end{array}$ & $\frac{\overline{1}}{\bar{x}}$ & $\frac{\bar{\pi}}{\frac{1}{x}}$ & $\frac{\bar{F}}{\frac{7}{x}}$ & $\begin{array}{l}\text { 右 } \\
\text { 侧 }\end{array}$ & 子 \\
\hline$\frac{\bar{t}}{-\vec{t}}$ & $\frac{\equiv}{\frac{1}{\pi g}}$ & $\frac{E}{\pi}$ & $\frac{E}{x}$ & $\begin{array}{l}\text { 有 } \\
\text { 明 }\end{array}$ & 多 \\
\hline$\frac{\bar{x}}{\underline{1}}$ & $\frac{1}{x}$ & $\frac{1}{\overline{1}}$ & $\frac{\overrightarrow{1}}{\frac{1}{n}} \frac{1}{\square+}$ & 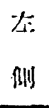 & 子 \\
\hline
\end{tabular}

た同 万時掞以就細

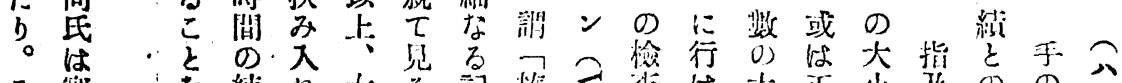

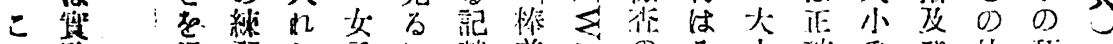

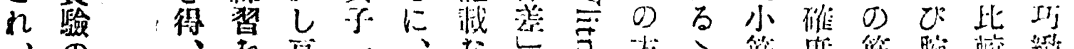

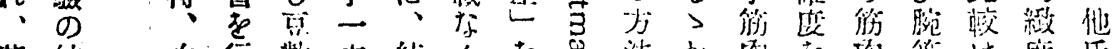

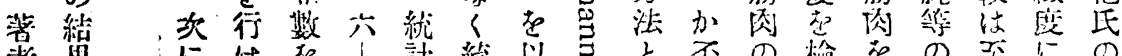

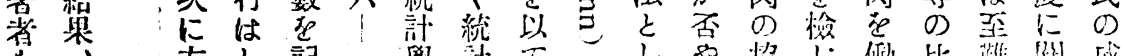

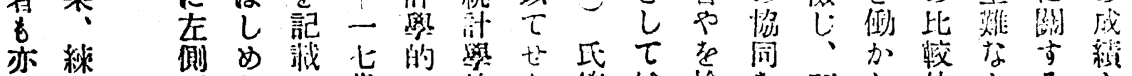

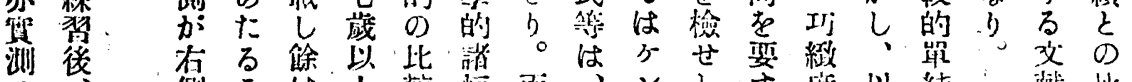

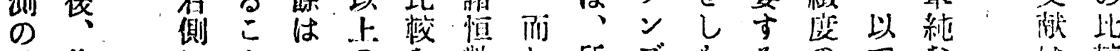

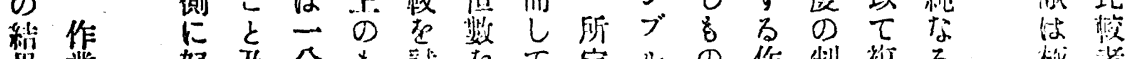

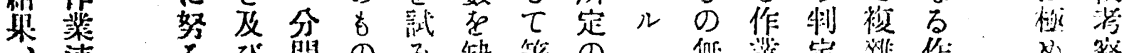

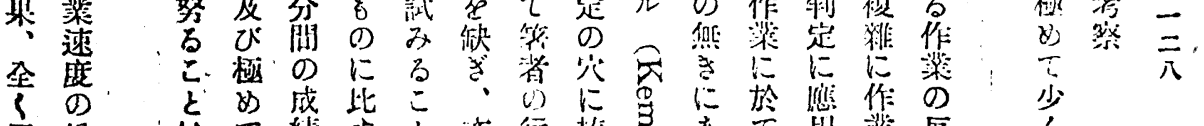

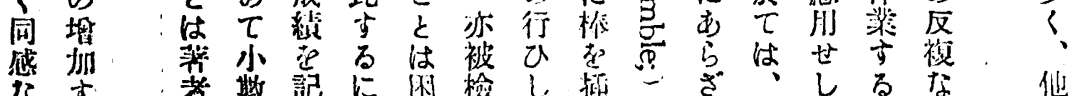

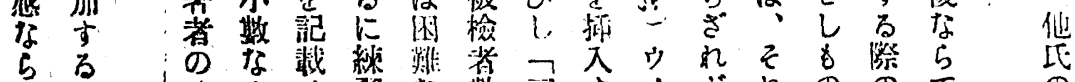

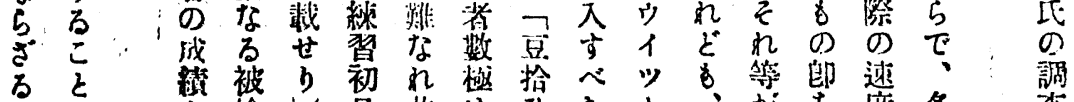

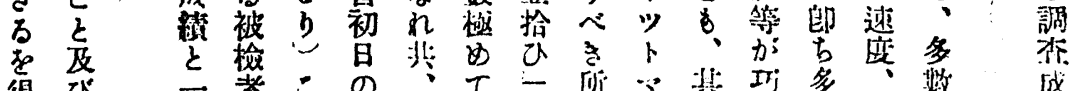

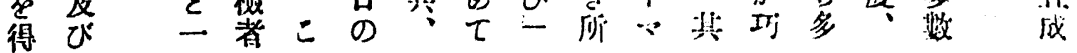


IV 往 239

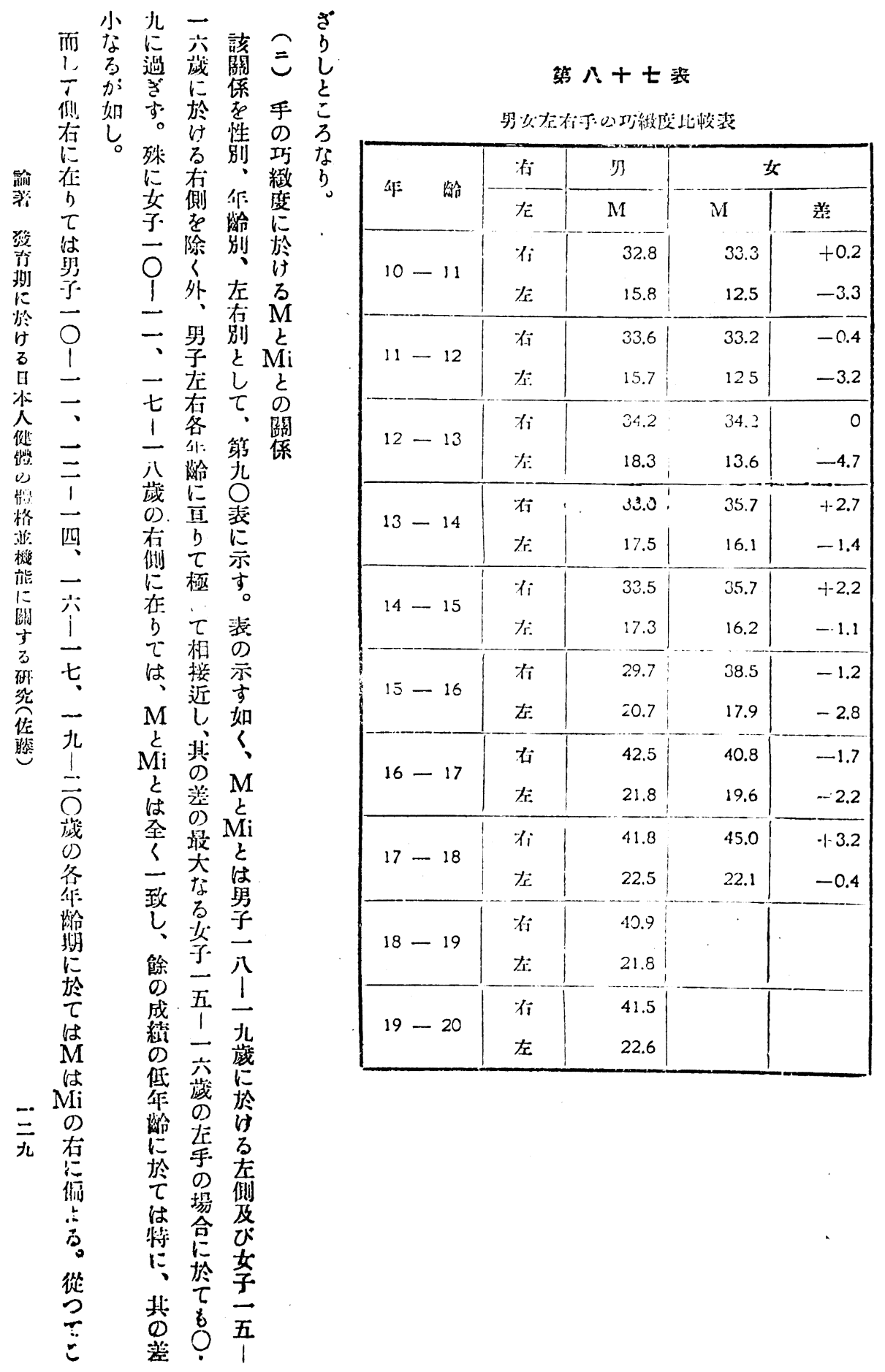




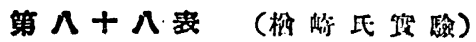

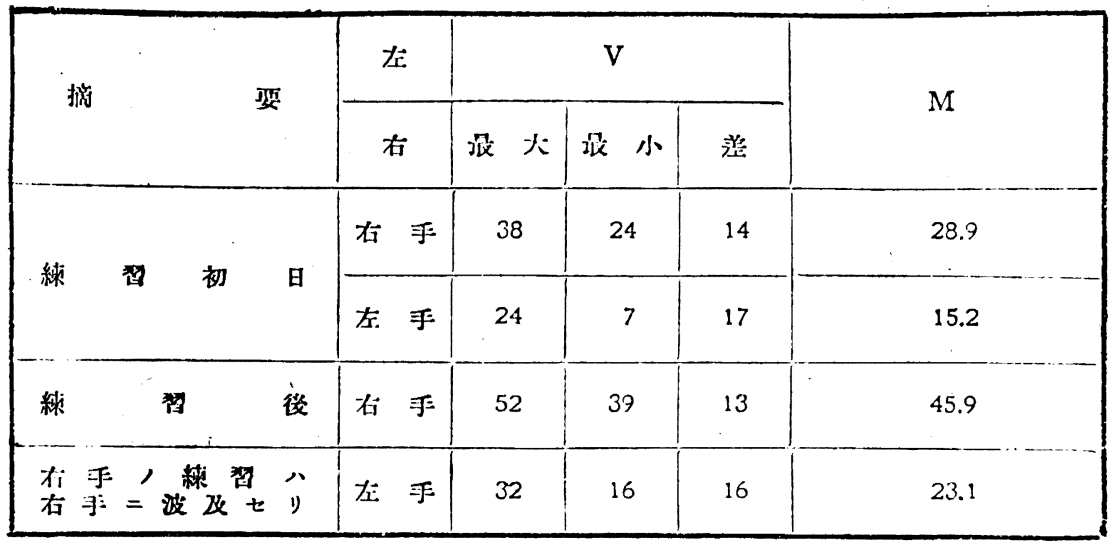

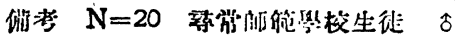

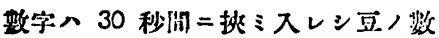

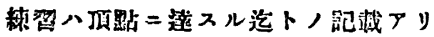

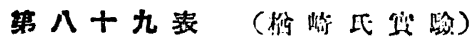

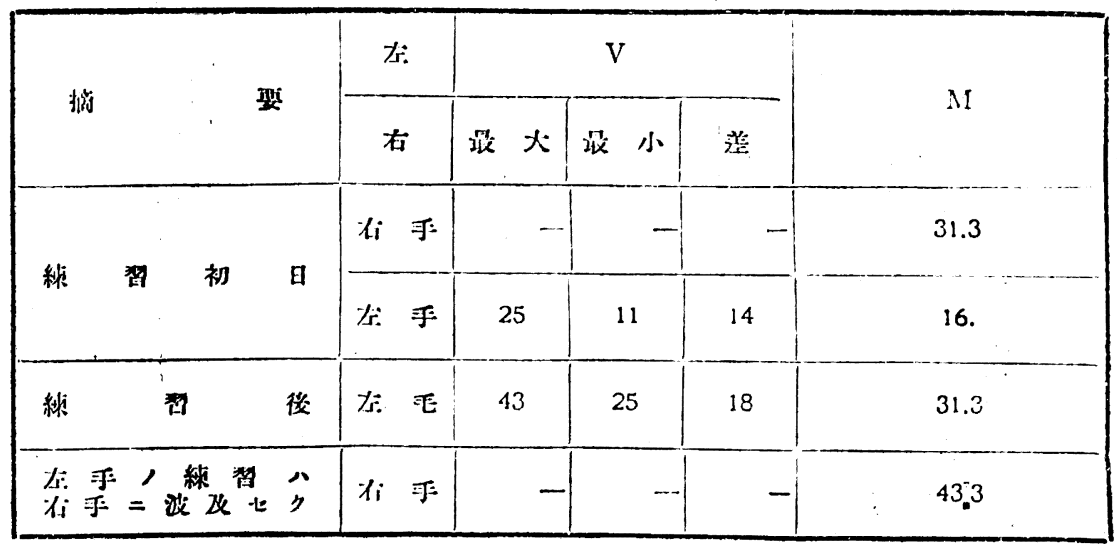

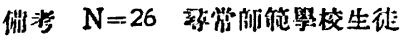

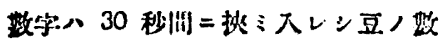

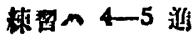




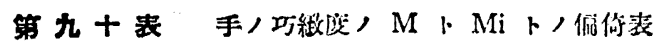

\begin{tabular}{|c|c|c|c|c|c|c|c|c|c|c|c|}
\hline 吽: & 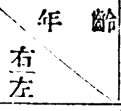 & $\mid 10-11$ & $11-12$ & $\mid 2-13$ & $3-14$ & $4-15$ & $15-16$ & $6-17$ & $17-18$ & $18-19$ & $19-20$ \\
\hline \multirow{2}{*}{. } & 不 & +0.3 & -0.4 & +0.2 & +0.5 & -0.5 & -0.3 & +0.5 & -0.2 & --0.1 & +0.5 \\
\hline & ts: & -0.2 & -0.3 & +0.8 & +0.5 & +0.3 & +0.7 & +0.8 & $\div 0.5$ & +1.8 & +0.6 \\
\hline \multirow{2}{*}{ 从 } & 右 & 0 & +0.2 & +0.2 & +0.7 & +0.7 & +1.5 & -0.2 & 0 & - & \\
\hline & $t_{s}$ & +0.5 & +0.5 & -0.4 & +0.1 & +0.2 & +0.9 & +0.6 & +0.1 & - & \\
\hline
\end{tabular}

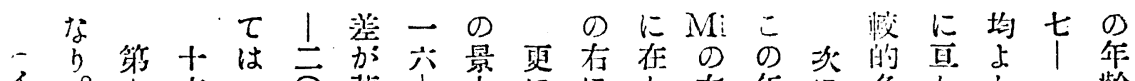

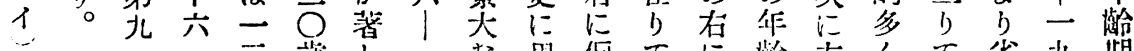

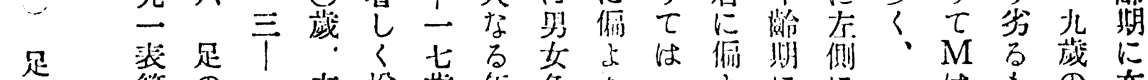

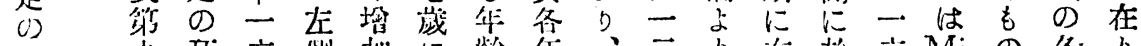

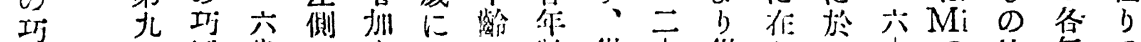

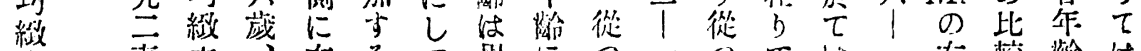

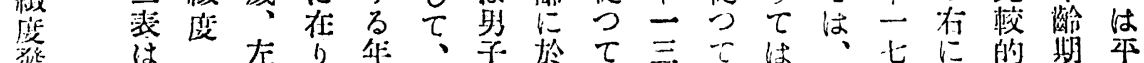

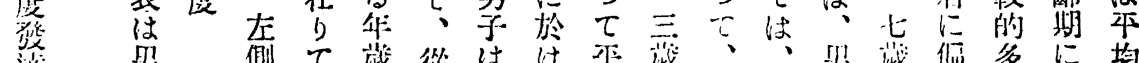

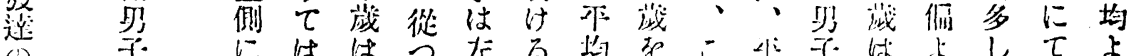

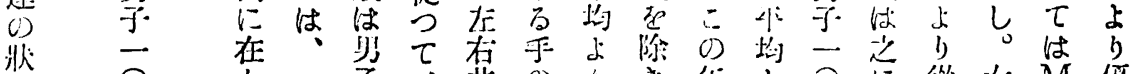
沙 $\overrightarrow{0} \quad$ 在

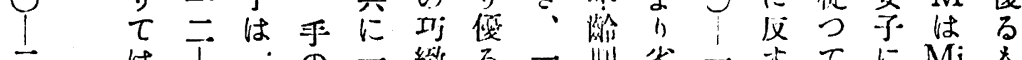

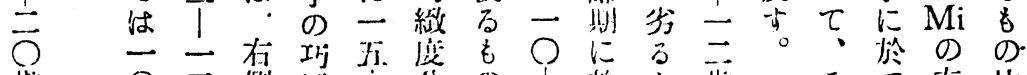

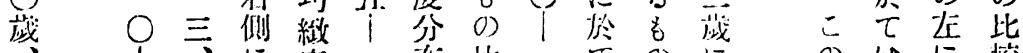

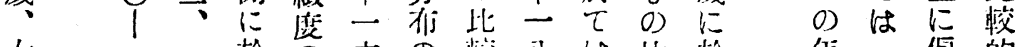

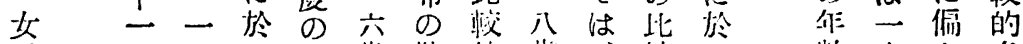

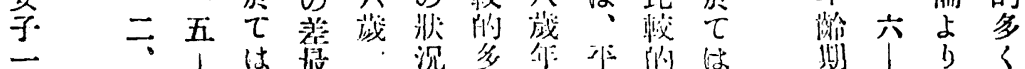

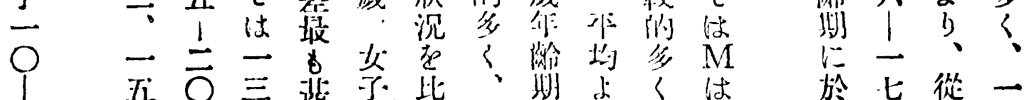

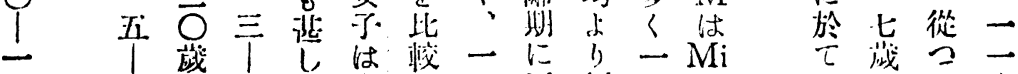

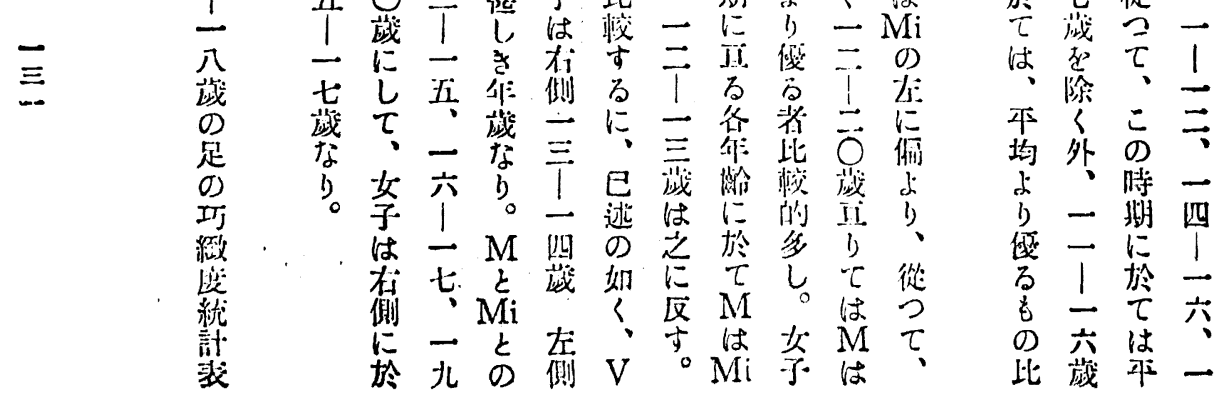




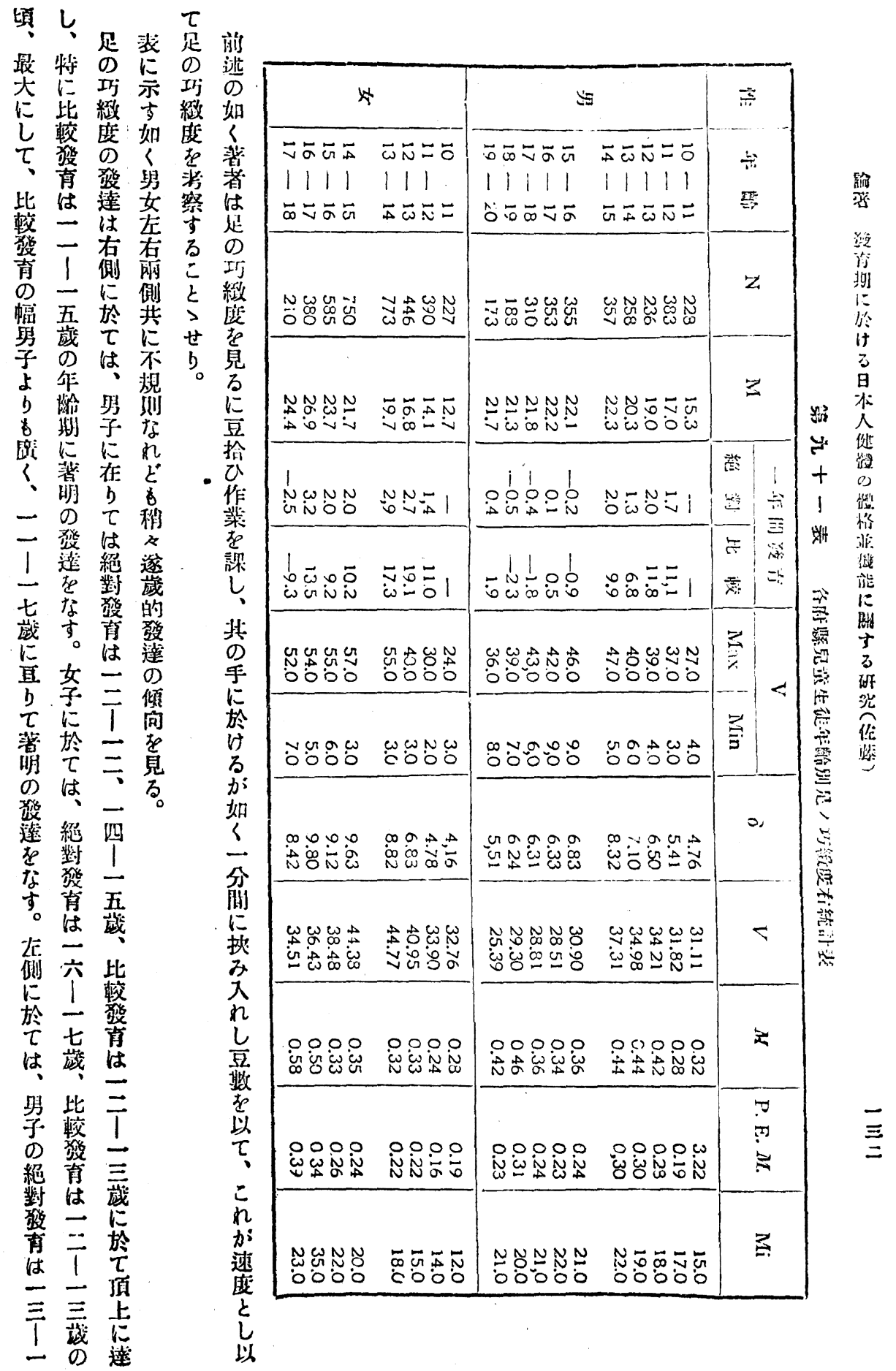


IV 243

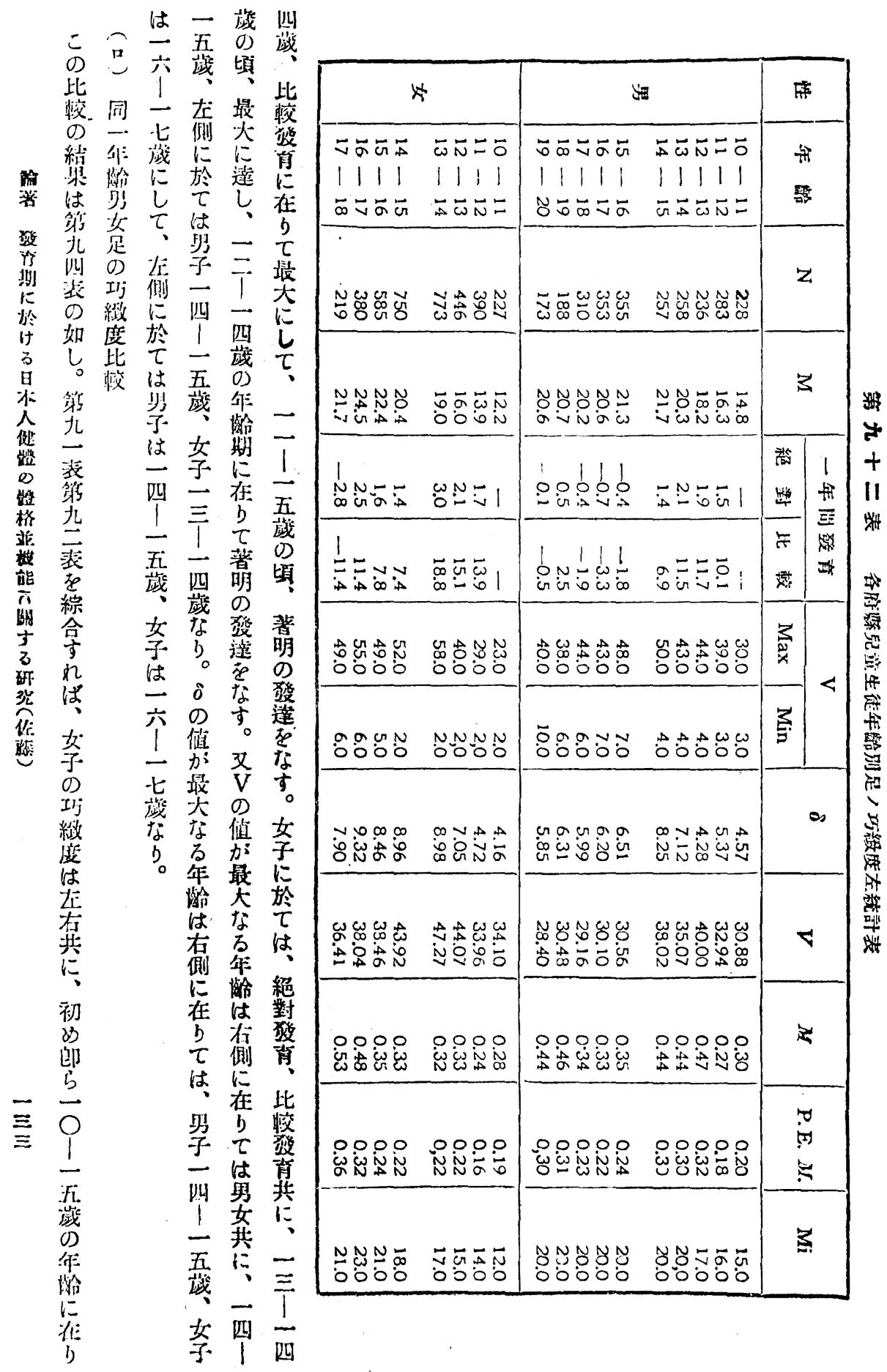


第九十四裂

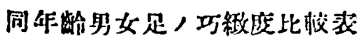

\begin{tabular}{|c|c|c|c|c|}
\hline \multirow{2}{*}{ 作 䍅 } & \multirow{2}{*}{$\frac{\text { 右 }}{\text { 左 }}$} & \multirow{2}{*}{$\frac{\text { 多 }}{M}$} & \multicolumn{2}{|c|}{ 女 } \\
\hline & & & $M$ & 曾 \\
\hline \multirow{2}{*}{$10-11$} & 存 & 15.3 & 12.7 & -2.6 \\
\hline & 左 & 14.8 & 12.2 & --2.6 \\
\hline \multirow{2}{*}{$11-12$} & 右 & 17.0 & 14.1 & -2.9 \\
\hline & tr. & 16.3 & 13.6 & -2.4 \\
\hline \multirow{2}{*}{$12-13$} & 右 & 19.0 & 16.8 & -2.2 \\
\hline & 左 & 18.2 & 16.0 & -2.2 \\
\hline \multirow{2}{*}{$13-14$} & 存 & 20.3 & 19.7 & +0.6 \\
\hline & tr. & 20.3 & 19.0 & -1.3 \\
\hline \multirow{2}{*}{$14-15$} & 右 & 22.3 & 21.7 & -0.6 \\
\hline & 左 & 21.7 & 20.4 & -1.3 \\
\hline \multirow{2}{*}{$15-16$} & 右 & 22.1 & 23.7 & +1.6 \\
\hline & 左. & 21.3 & $22 \cdot 4$ & +1.1 \\
\hline \multirow{2}{*}{$16-17$} & 石 & 22.2 & 26.9 & +4.7 \\
\hline & 左 & 20.6 & 24.5 & +3.9 \\
\hline \multirow{2}{*}{$17-18$} & 右 & 21.8 & 24.4 & +2.6 \\
\hline & t. & 20.2 & 21.7 & +1.5 \\
\hline \multirow{2}{*}{$18-19$} & 杖 & 21.3 & & \\
\hline & t t & 20.7 & & 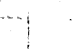 \\
\hline \multirow{2}{*}{$19-20$} & 右 & 21.7 &. & i \\
\hline & tr & 20.6 & 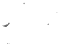 & \\
\hline
\end{tabular}

第九十三裴

\begin{tabular}{|c|c|c|c|c|}
\hline 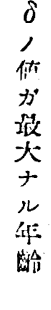 & 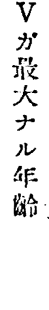 & 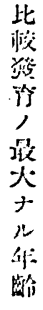 & 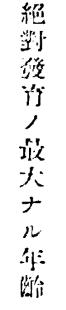 & 敵 \\
\hline$\frac{1}{\vec{a}}$ & $\frac{\overline{1}}{\overline{z a}}$ & $\underline{\equiv}$ & 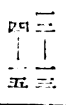 & \\
\hline$\frac{\sqrt{2 \pi}}{\bar{x}}$ & 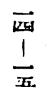 & $\begin{array}{l}\equiv \\
\frac{1}{\equiv}\end{array}$ & $\frac{\overline{1}}{\square \square}$ & 侄 \\
\hline$\frac{\bar{x}}{E}$ & $\underset{i \sqrt{2}}{\mid \overrightarrow{m a}}$ & $\overline{\underline{\underline{1}}}$ & $\frac{i}{i}$ & 位文 \\
\hline$\frac{\bar{X}}{\overline{1}}$ & $\frac{\vec{\equiv}}{\vec{v}}$ & $\frac{1}{R \square}$ & $\frac{7}{\frac{7}{6-1}}$ & (6ij \\
\hline
\end{tabular}

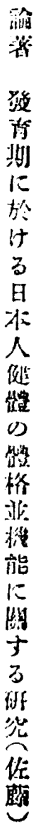

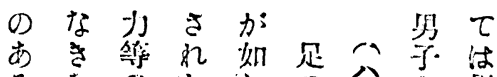

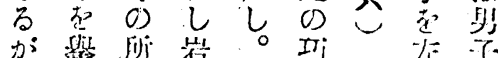

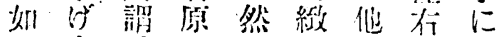

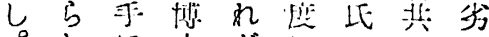
$\iota に \pm \varepsilon に \omega に$

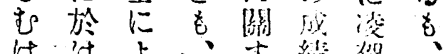

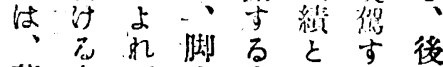

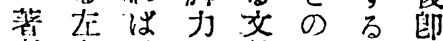

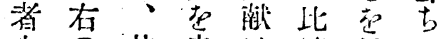

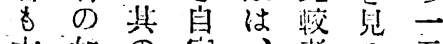

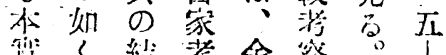

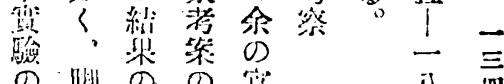
の脚の公西

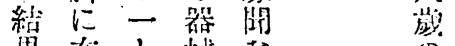
果在と杫な z し に

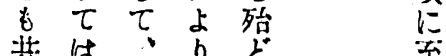
通左脚宁全系

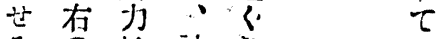

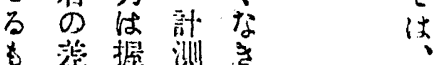




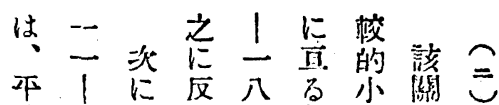

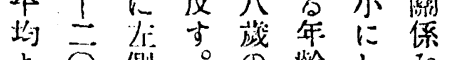

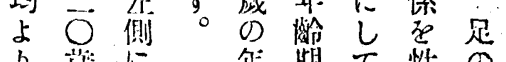

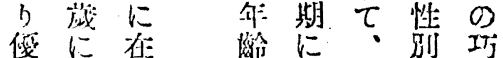

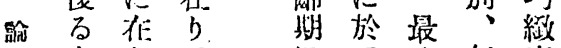

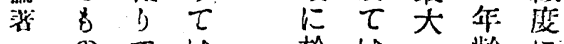

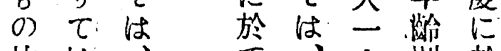

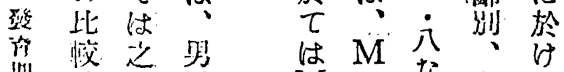

些的芯势 M は

於多卧楼 $\mathrm{Mi}$ 。存 $\mathrm{M}$

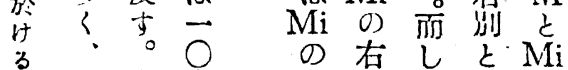

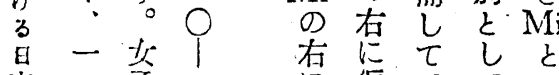

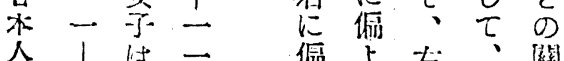

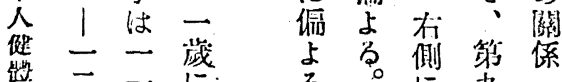

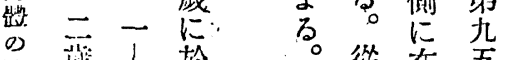

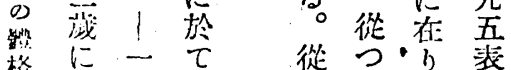

桥於

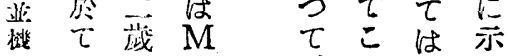

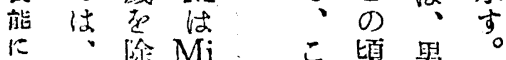

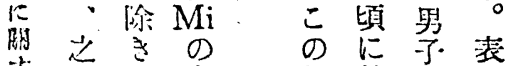

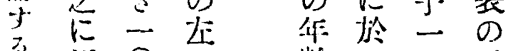

昨文 $O$ 制穴一示

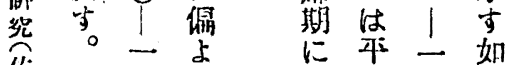

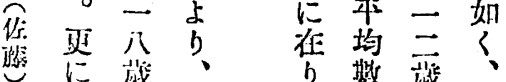

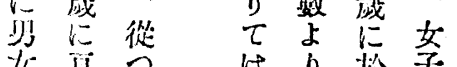

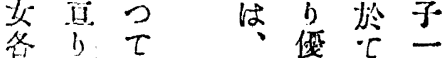

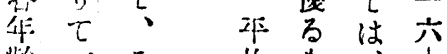

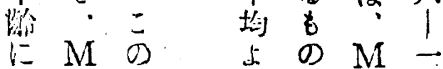

於は作尚比它

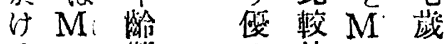

る.の期的はに

是不目多圣於

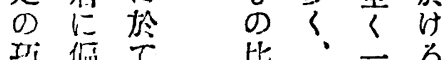

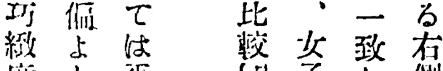

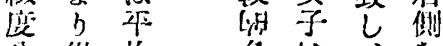

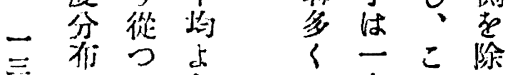

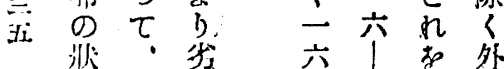

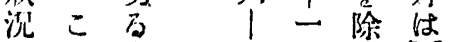

娄方

比作

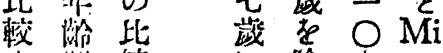

夺地校除厂の

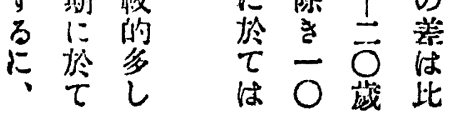

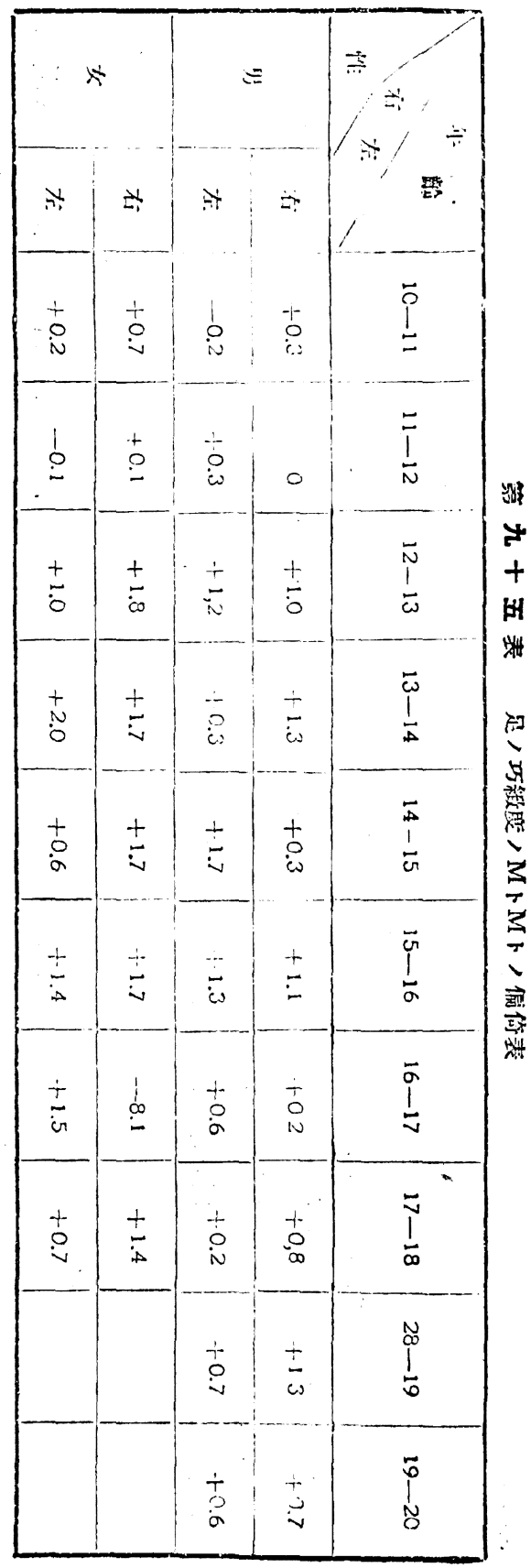




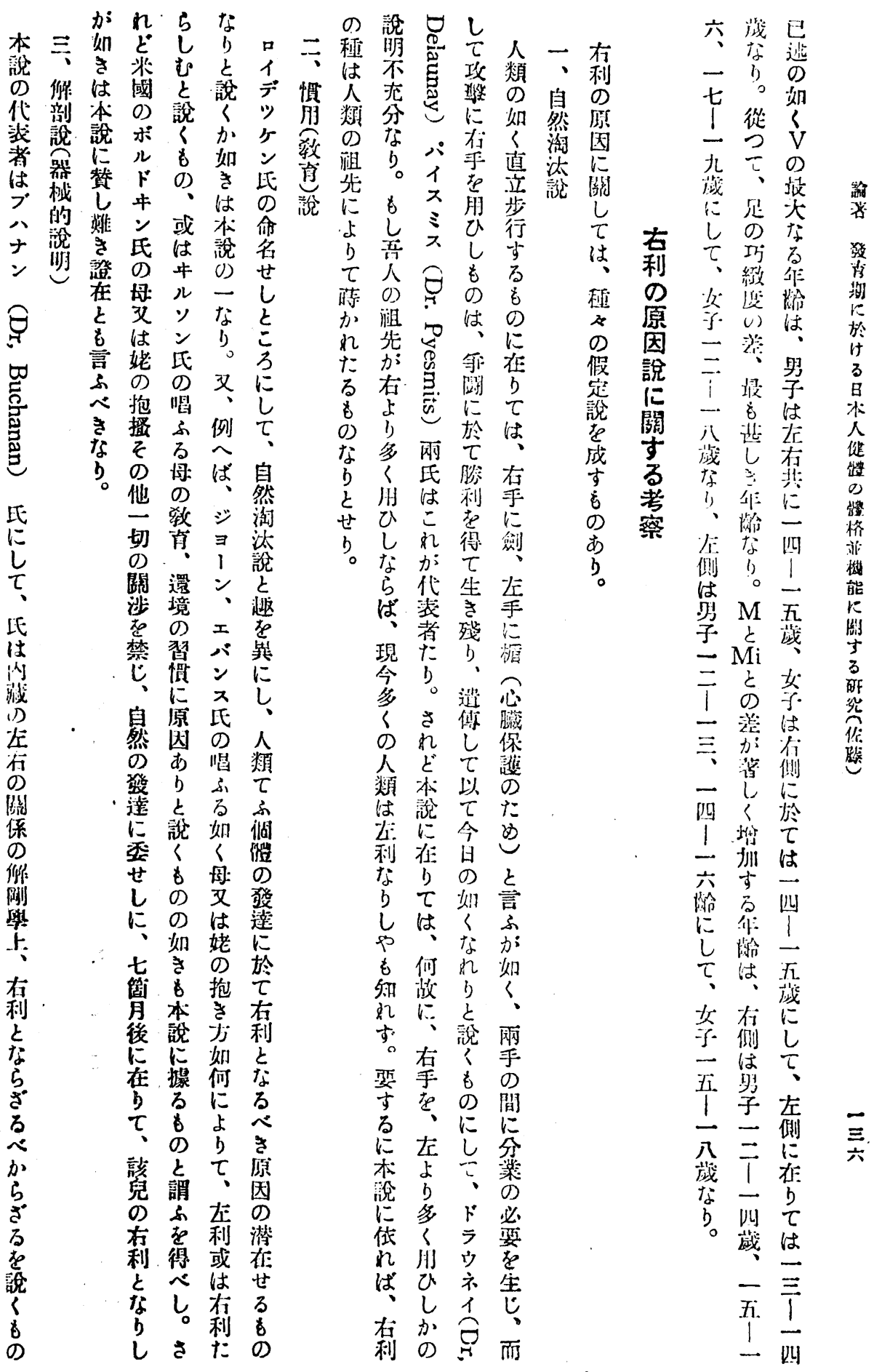




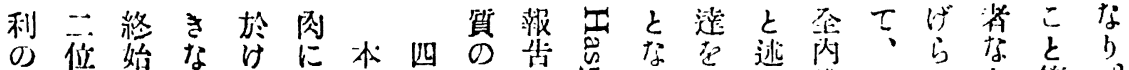
如焦始な

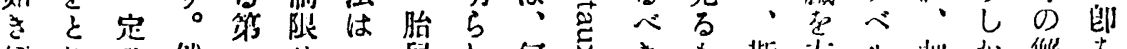

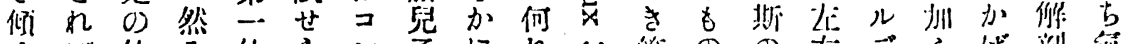

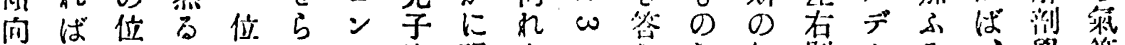
のと留に一る下官現もトなな如别

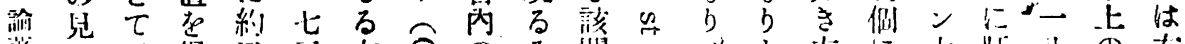

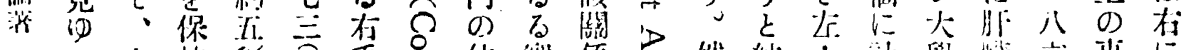

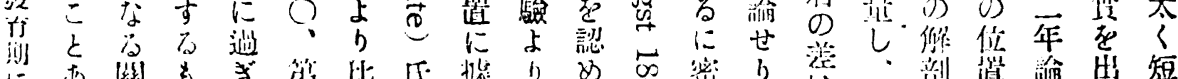

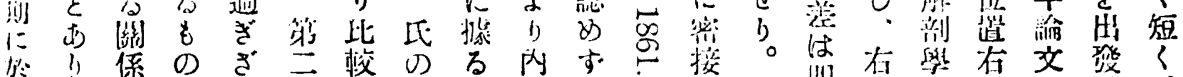

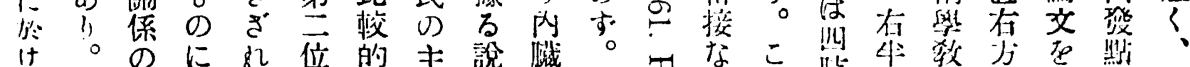

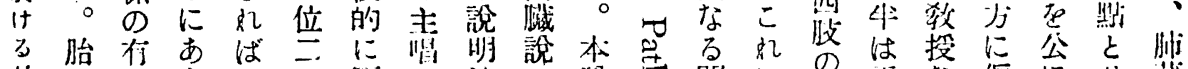

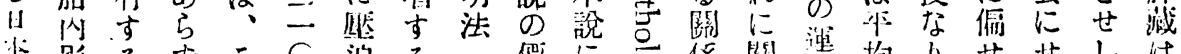

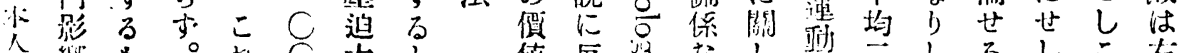

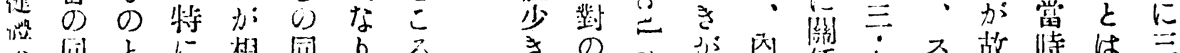

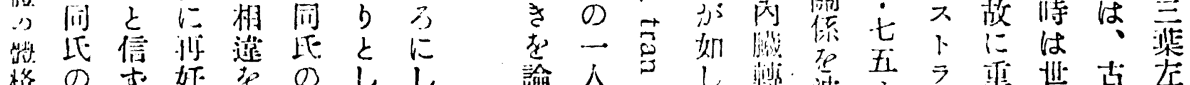

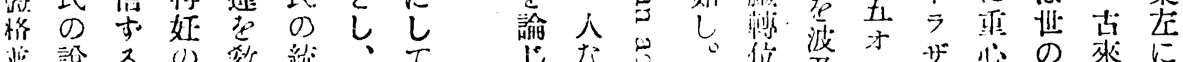

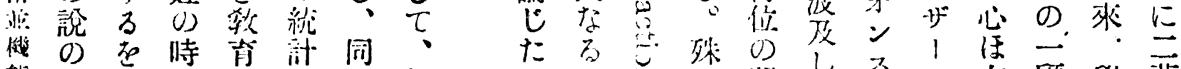

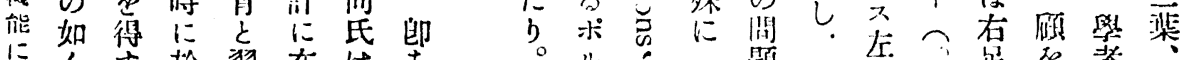

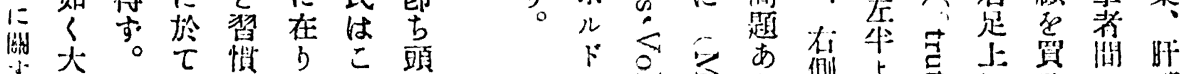

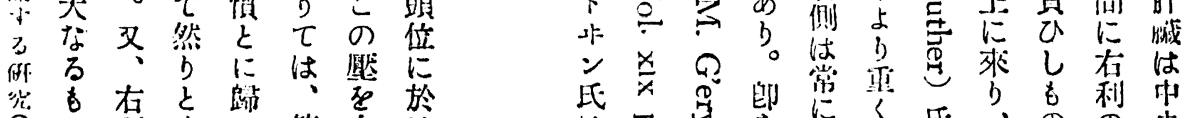

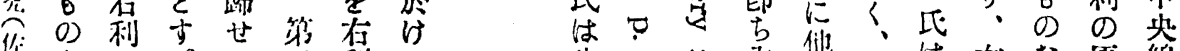

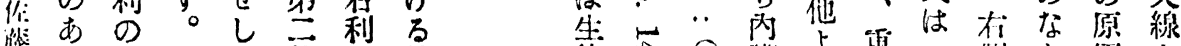

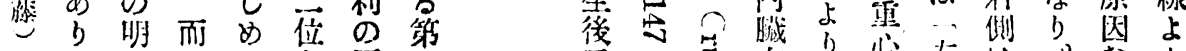

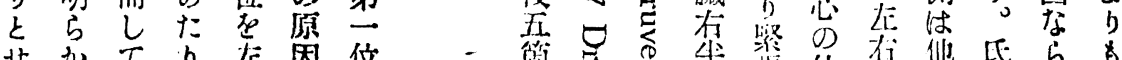

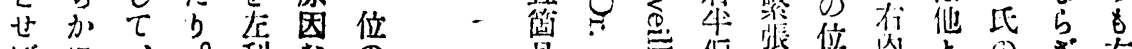
初触こざ 明方泉舅兒

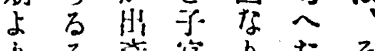
门る落窝bた飞 存利尛励胎せ 利先近脽せ而手

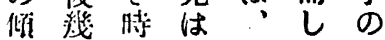
间月期姡少 $\tau$ 母

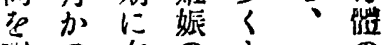
一現の住 $の r \rightarrow の$ 三卞後 b 初。怔

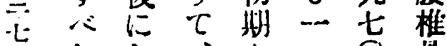
点 ᄂ 前 $\begin{aligned} & 5 \\ & \text { b }\end{aligned}$ の、迹来はの押 な初の 期左 形 さ

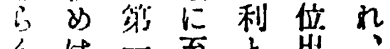

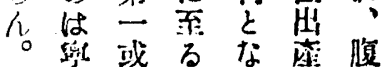
り万は茫る兒部

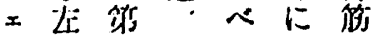

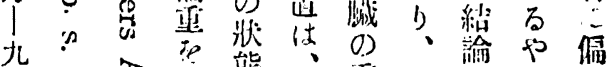

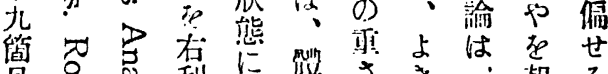
月 号索梨占 未 た因從線心犯はめ 步田宁な從線の息吸た在 行合马方占位た籍る右 學要公せ ば 祭尔ば

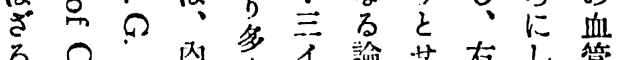

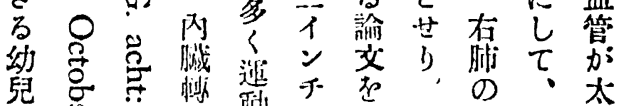

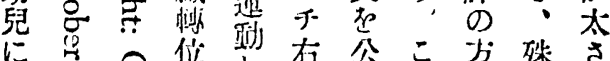

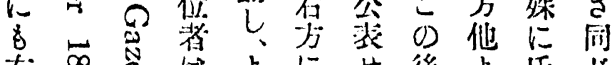

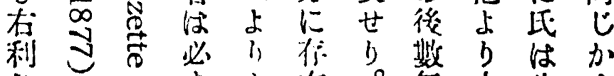

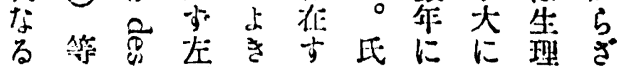

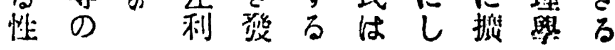




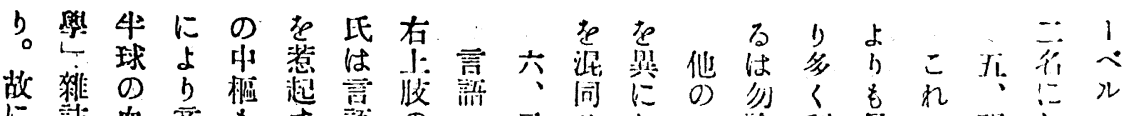

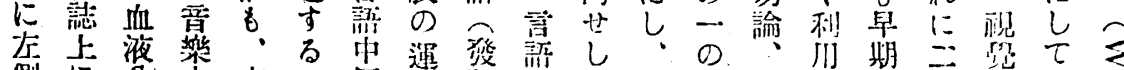

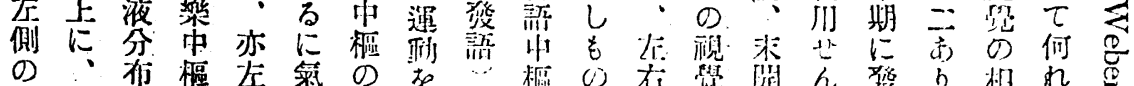

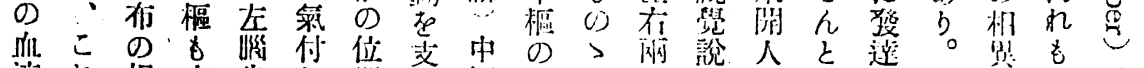

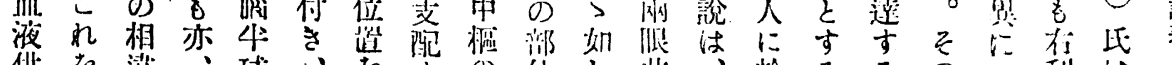

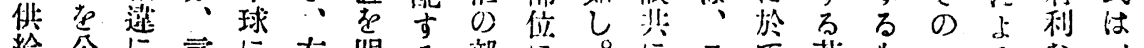

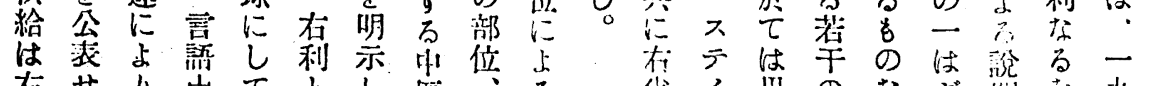

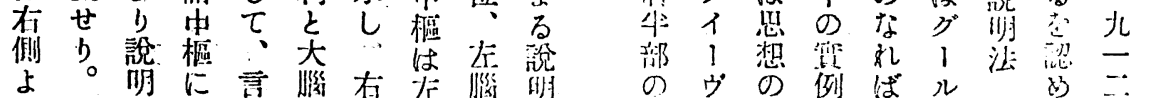

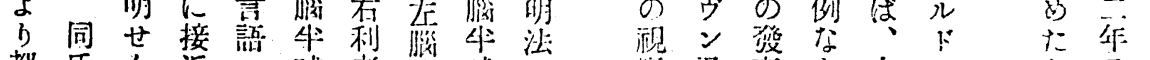
都氐凡近球者出球 合にと發衣の球に

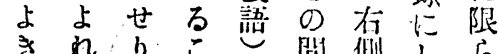
被

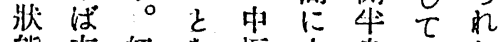

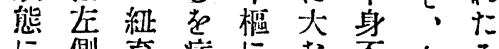

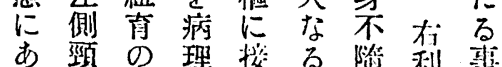

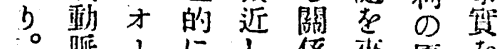

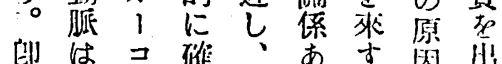

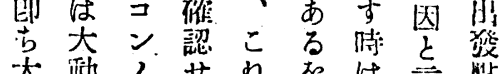

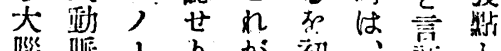

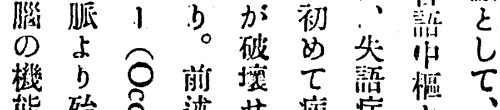
態殆导述せ病症点右

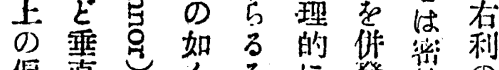

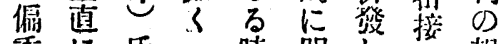

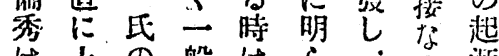

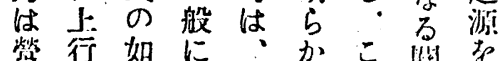

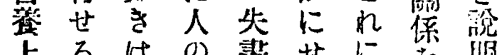

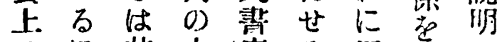

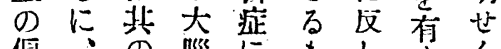

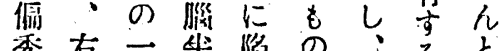

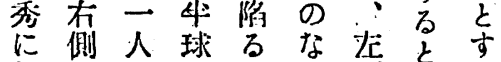

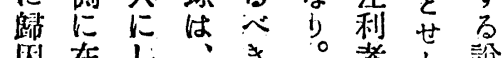

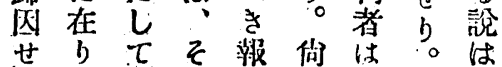

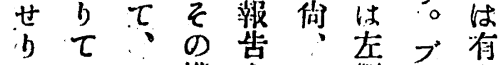

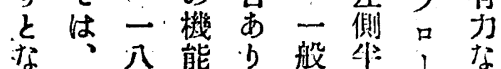

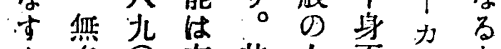
。算口左掑人不 の動年 のに慥可の

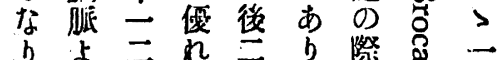

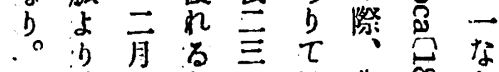

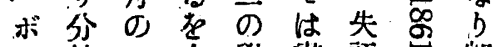

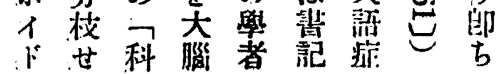




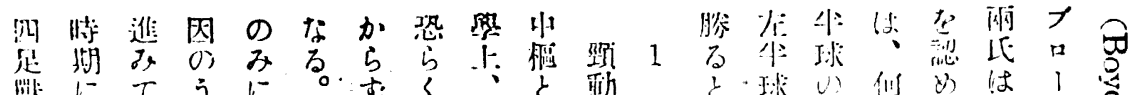

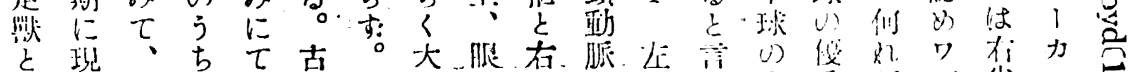

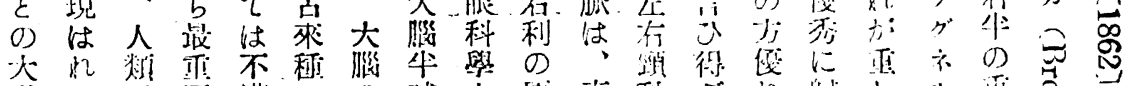

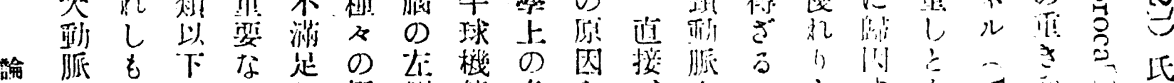

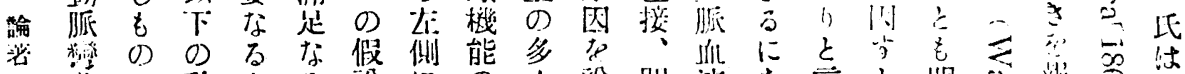

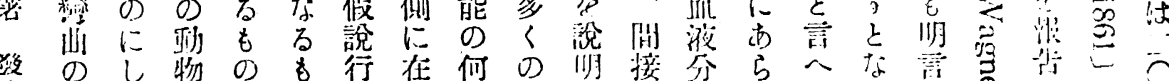

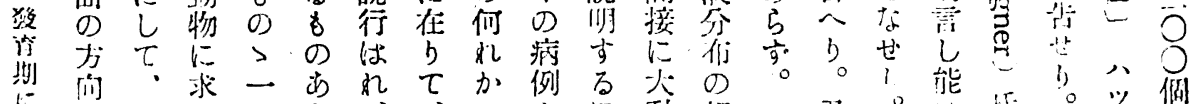

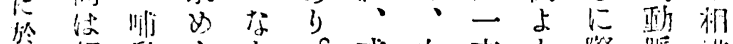

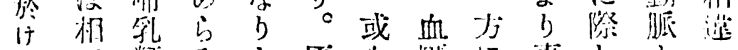

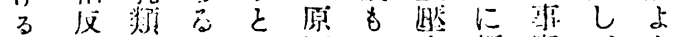

11 岁に心倍因の高俄留、b

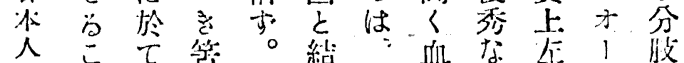

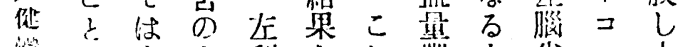

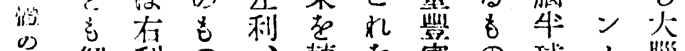

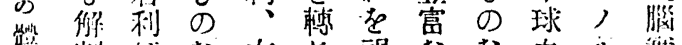

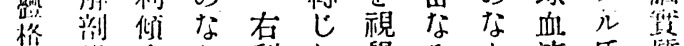

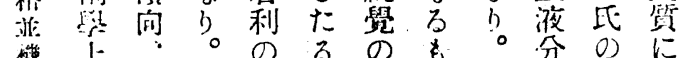

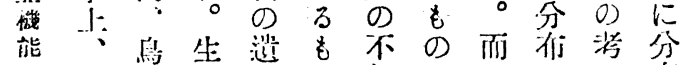

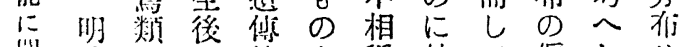

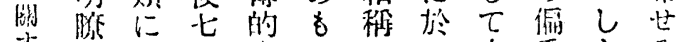

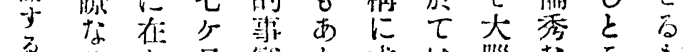

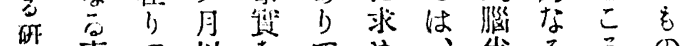

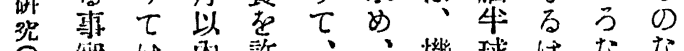

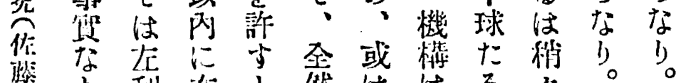

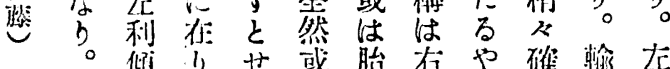

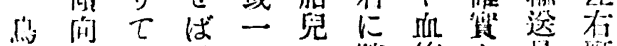

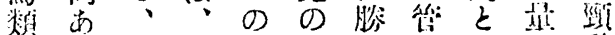

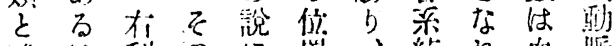

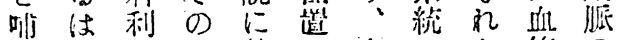

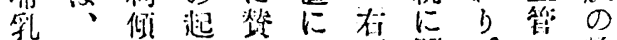

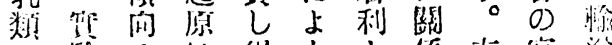

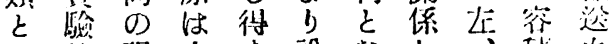

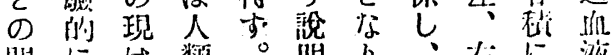

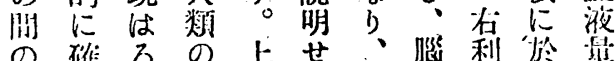

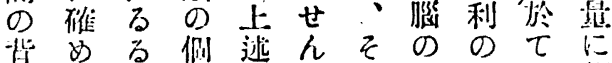

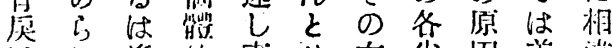

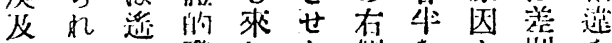

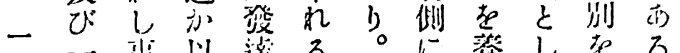

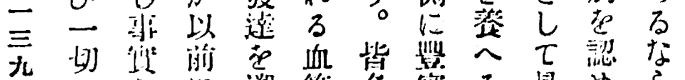

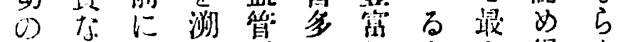

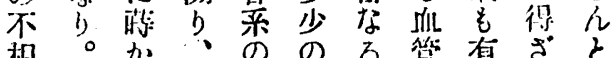

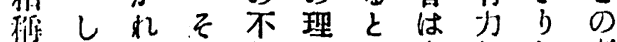

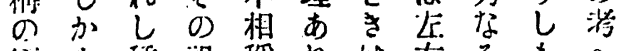

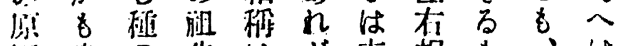

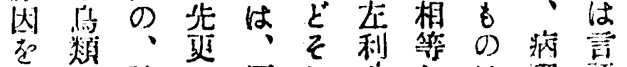

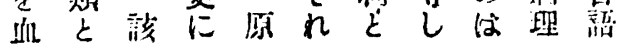




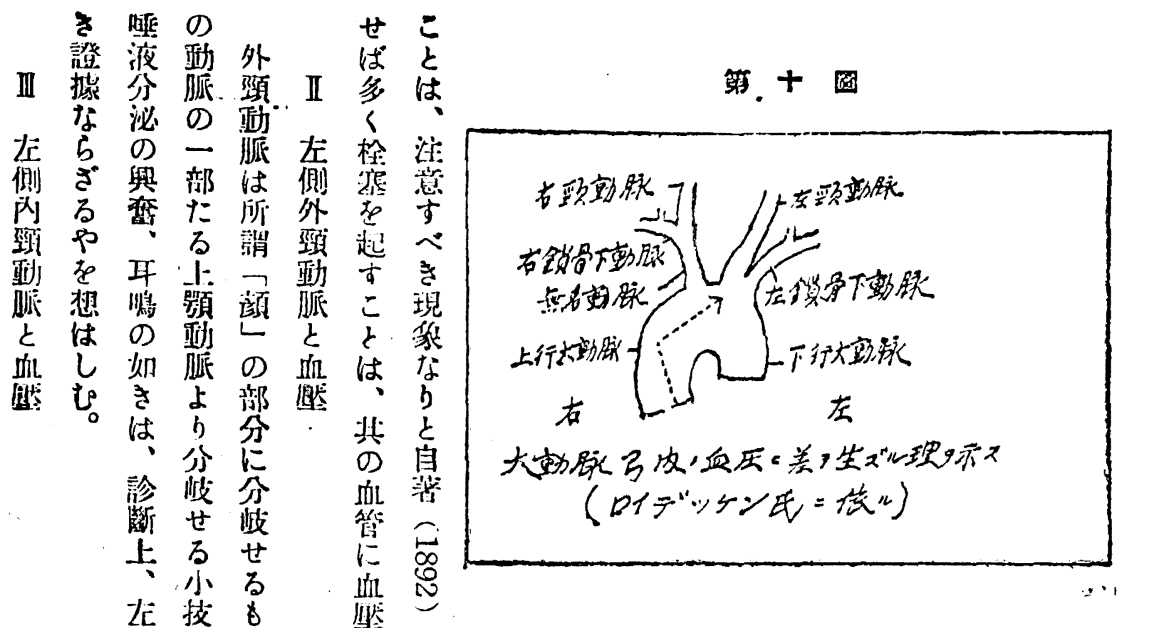

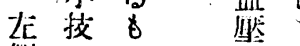

側にの のに

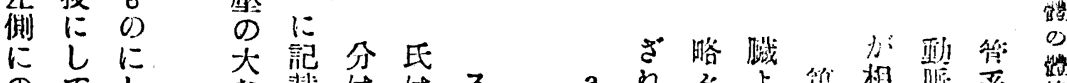

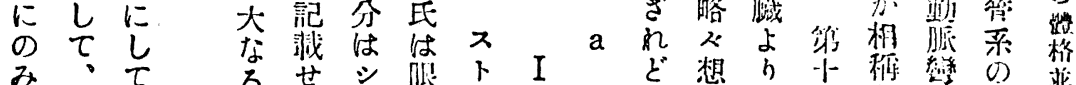

起跛、 る せ

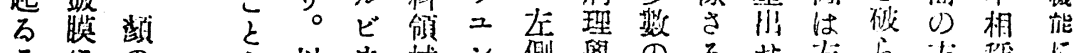

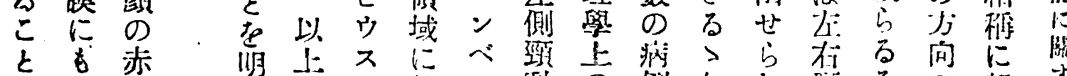

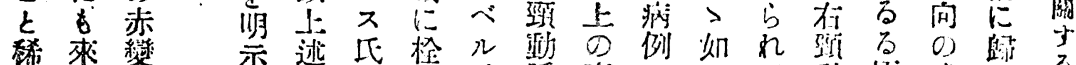

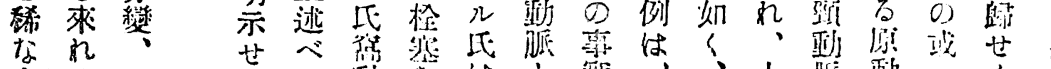

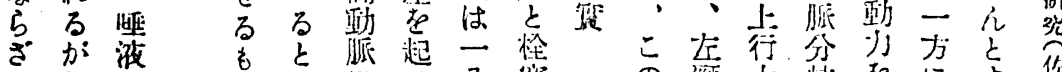

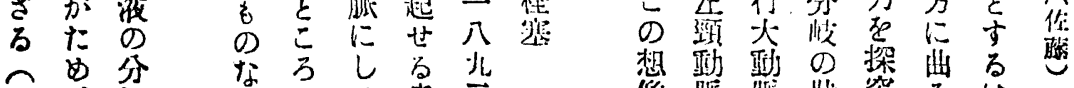

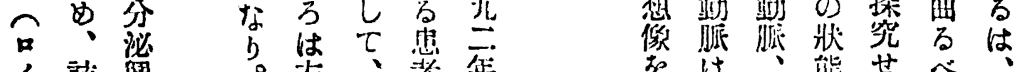

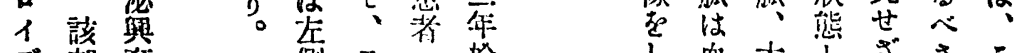

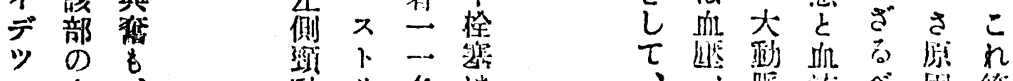

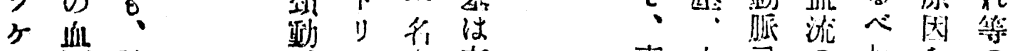

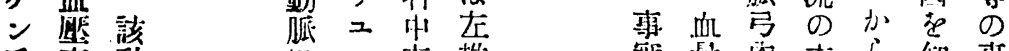

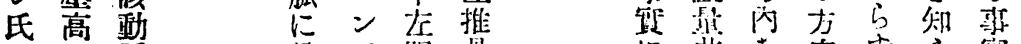

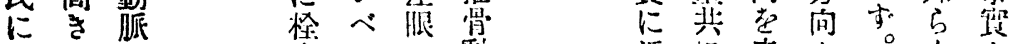

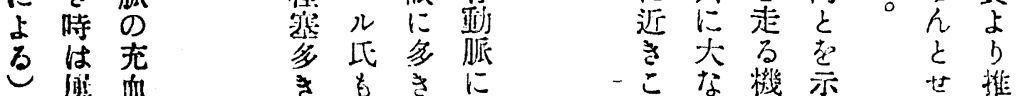

县 血

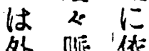

确报了

徱

脈件 又

0) S 耳

志铍に

侧動来

䣋感る

然守。血

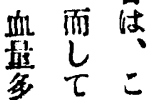

若惫多

侧被

證該啙 こ

明眼当蛋

せは。迱

る存最へ

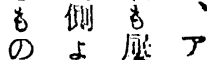

にb $\quad b \quad$

し 导 隻

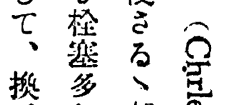

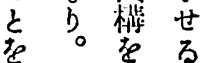

證藍示皇

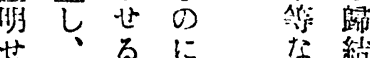

万こすし 万緗四

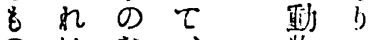

のはな、、物

な 一 b點 に更

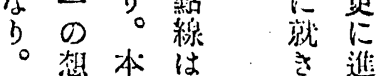

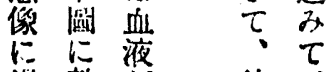

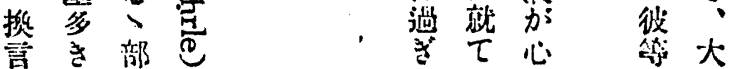




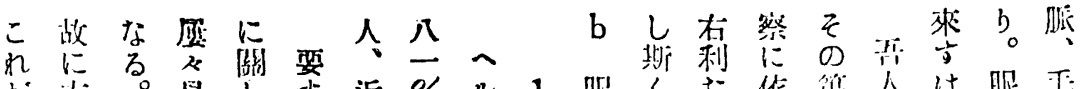

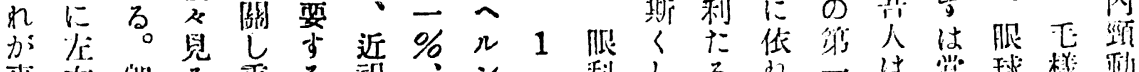

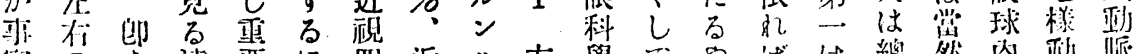

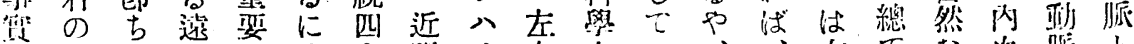

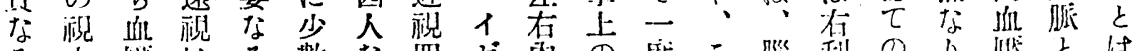

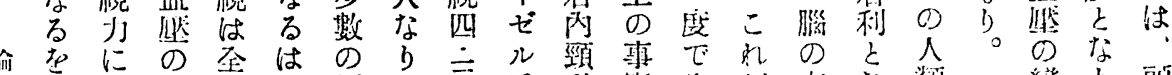

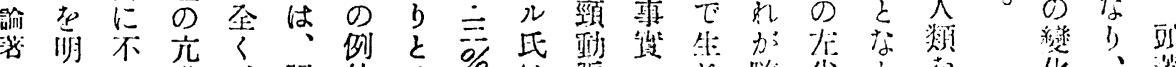

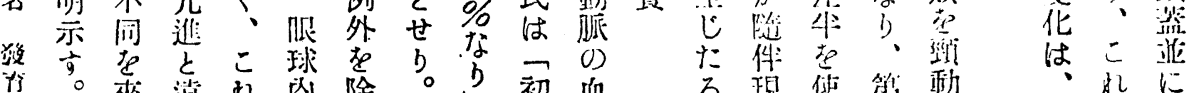

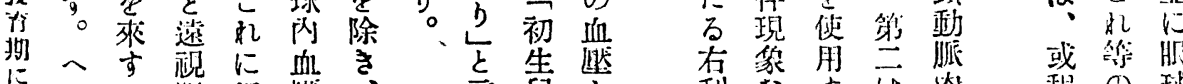

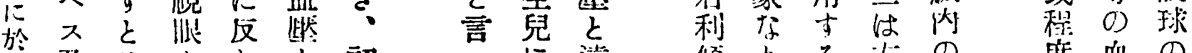

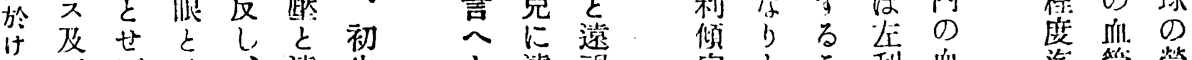

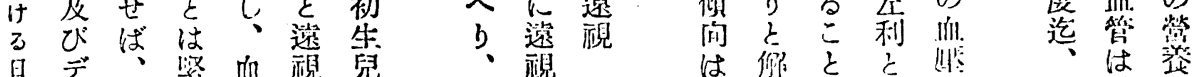

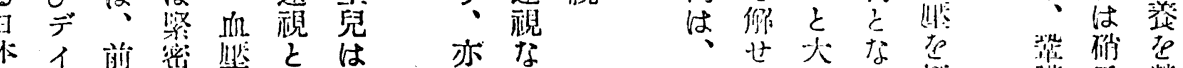

人 1 述望盟点は

件 デの年弱間少 1 ざ

谈理關めに遠佂る

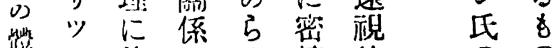

格》依苯る接的のの

业入り有るな倾赫㠫

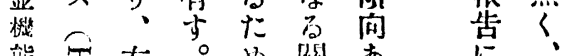

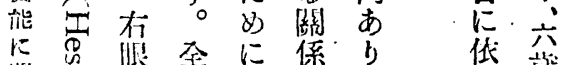

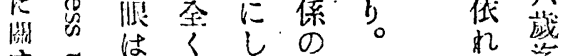

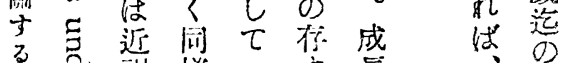

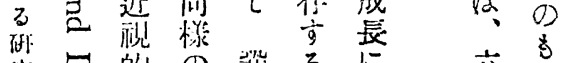

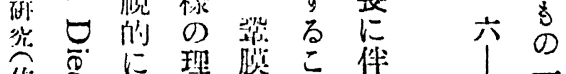

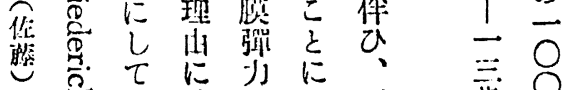

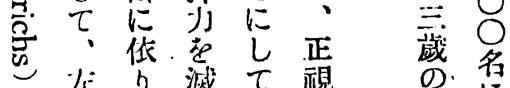

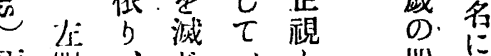

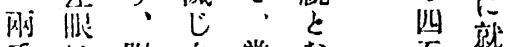

牫は腿血常な 五就

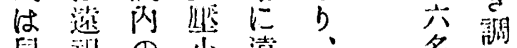

兒酘の少遠。名盗

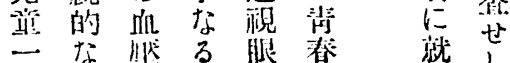

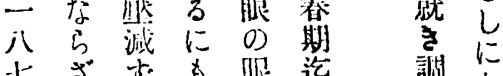

㫐ざ

人心㭙ら呙軸少

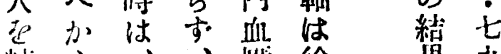

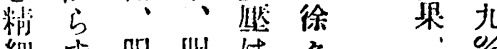

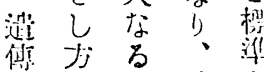

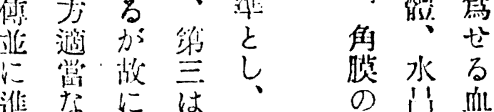

榄一䍃

進なには、の少

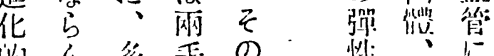

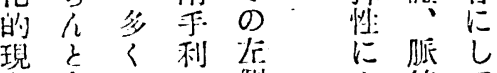

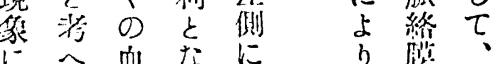

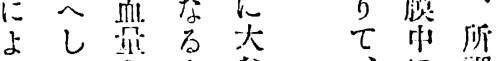

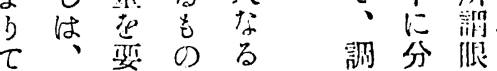

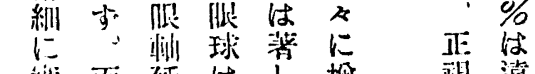

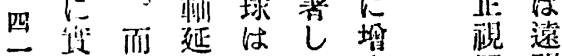

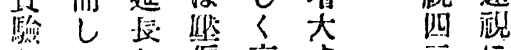

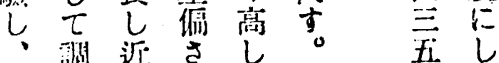

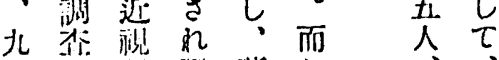

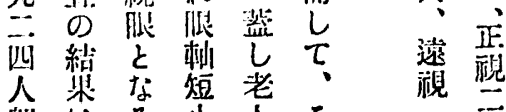

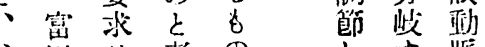

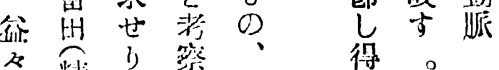

こ粗尛筞右得败は

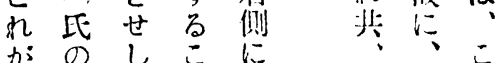

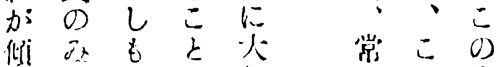

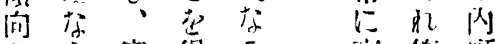

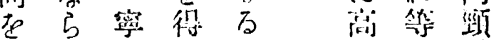

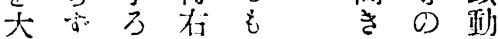

な蓝、剩の血血脤

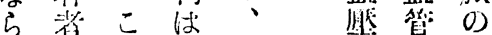

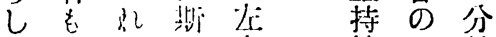

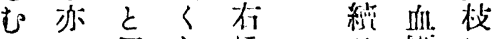

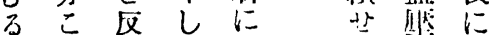

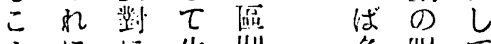

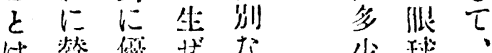

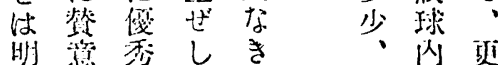

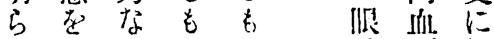

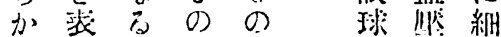

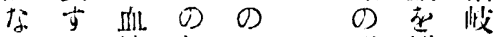

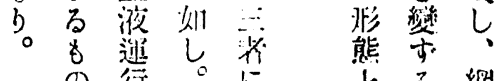

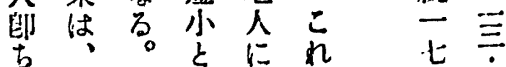

の行。に 」: る 絧

な從大它は腅

b主来别綝朋中

陑し浇高华際心 


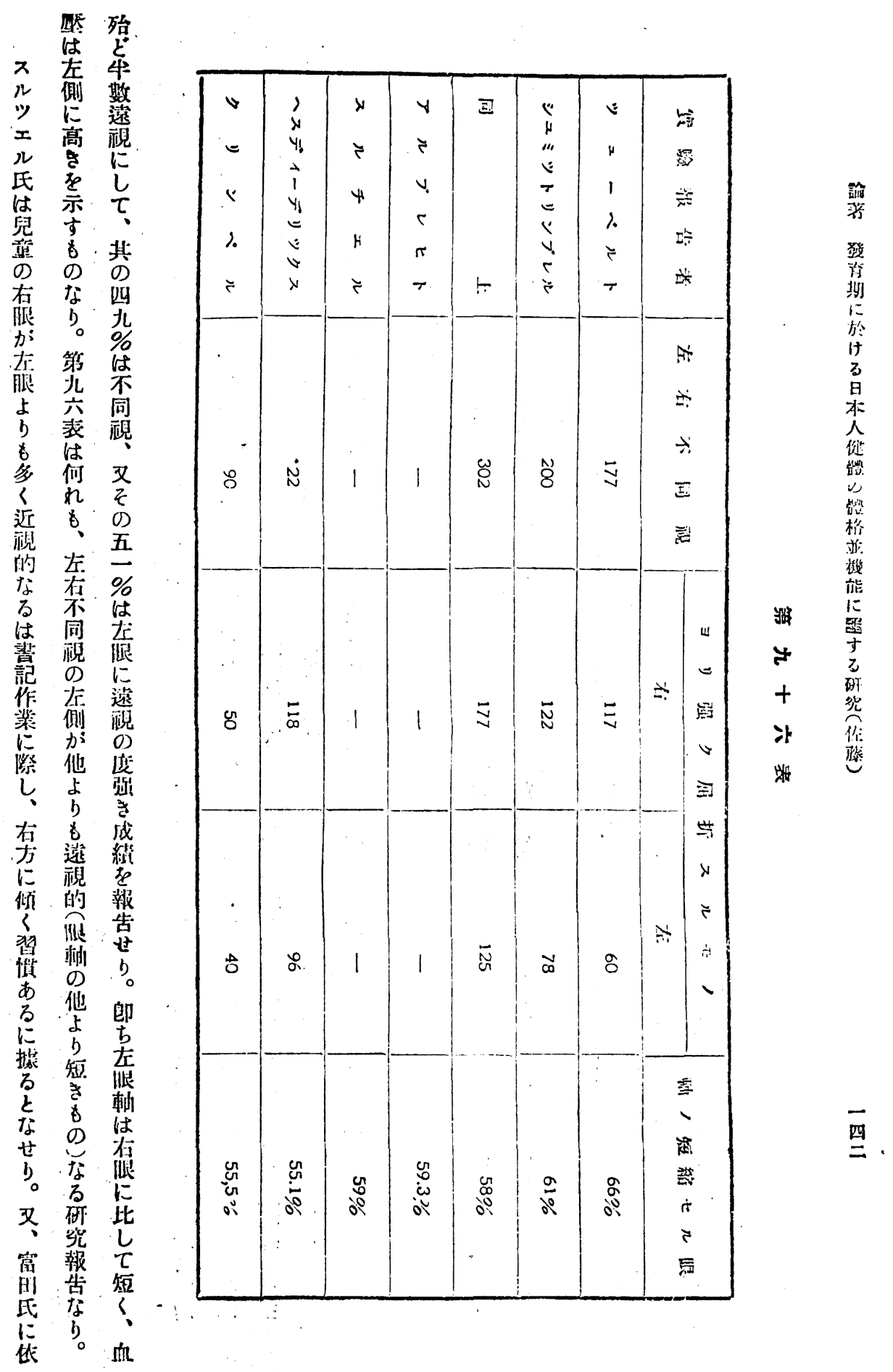




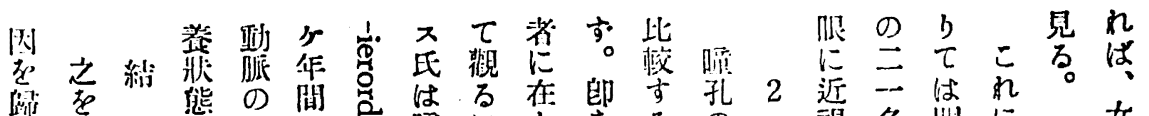

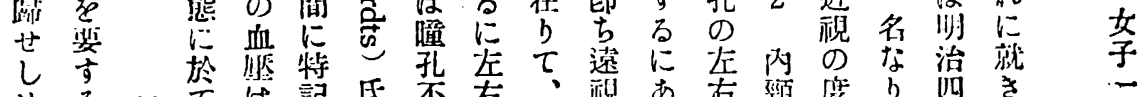

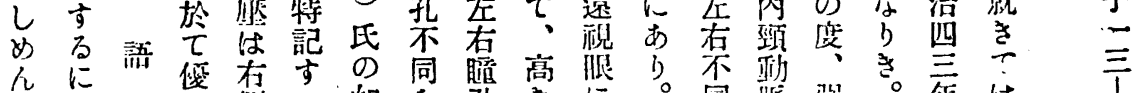

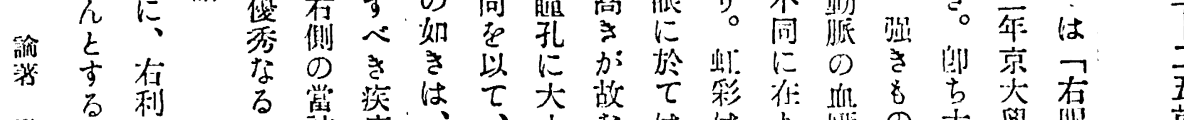

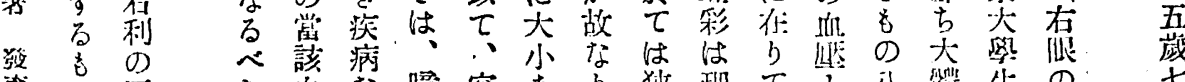

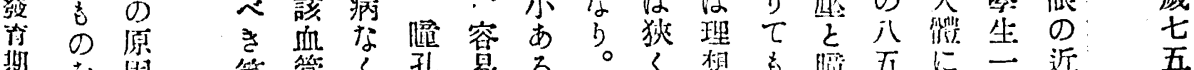

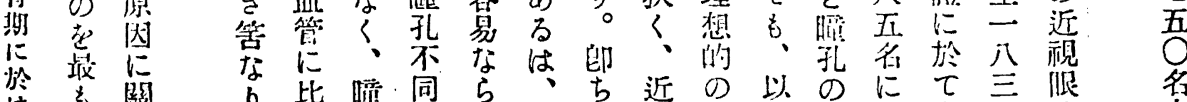

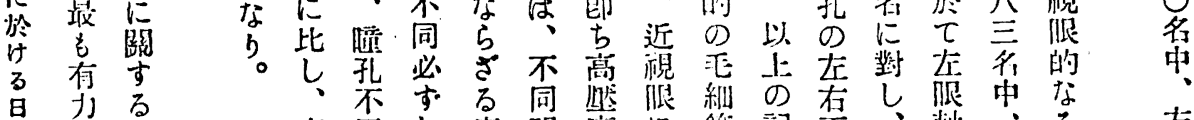

本禁鼎

人 门涗

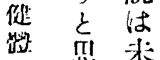

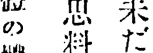

格紫全

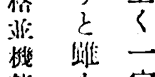

態范, 定

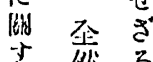

己 然

研琙

伀视な

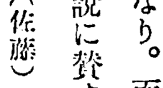

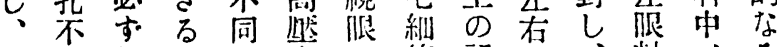

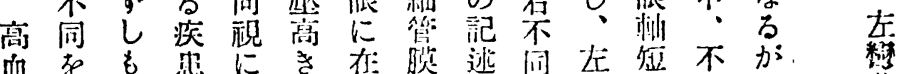

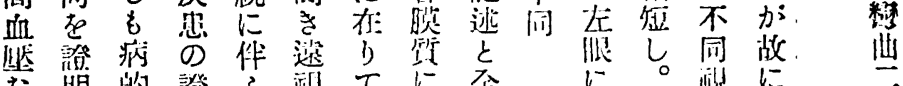

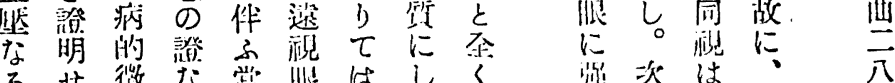

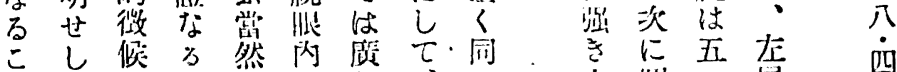

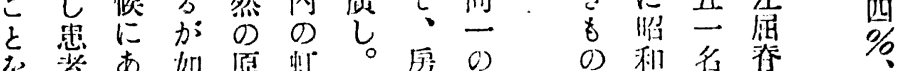

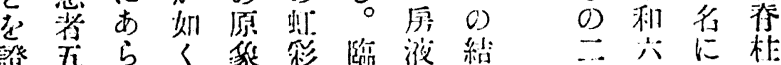

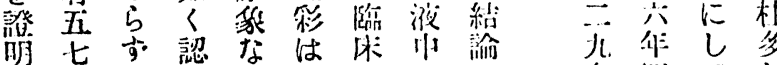

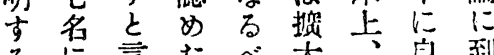

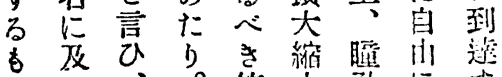

名川元璘

代、。管小扎主。

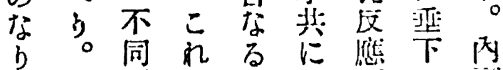

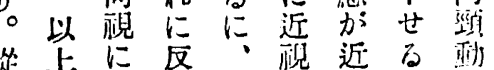

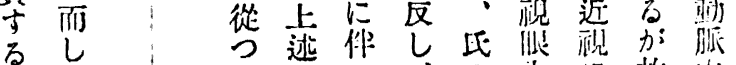

$\stackrel{2}{\tau}$

$\tau$ へ

余

皇方

标界

ris

点

5 性

$\varepsilon$ 㟈

、棑原 $シ$ 推の灯洫

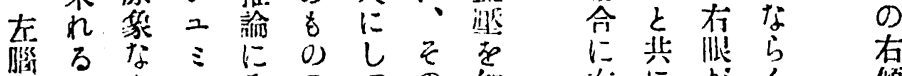

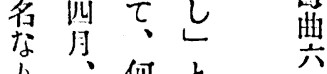

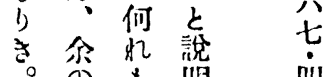

印踰近世界

古梁视方 印

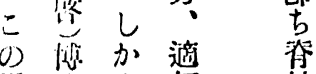

埸

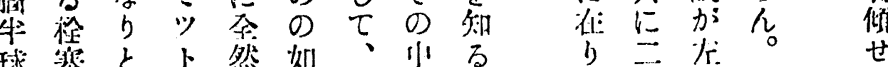

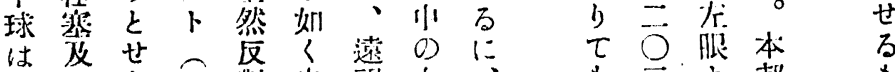

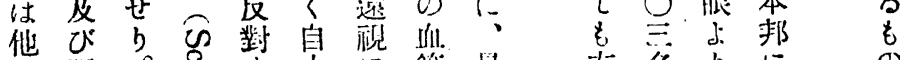

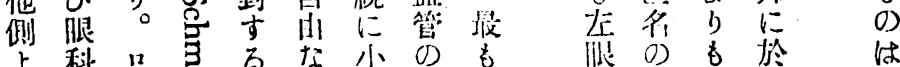

こ

- な U

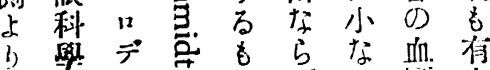

多:

请不底计

は 闬强了倾

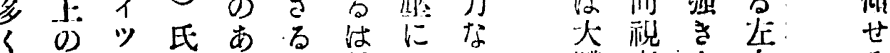

哭 号。偳

の病ら皮b就前る

面例ンび。明者它は

滥老苦右

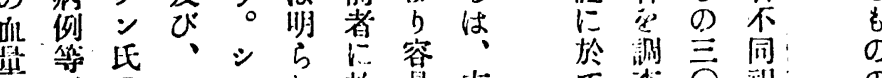

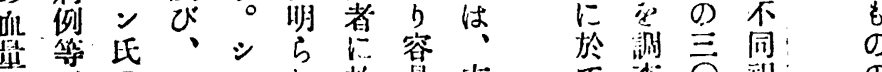

る

整

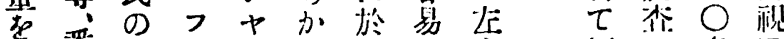

の

览

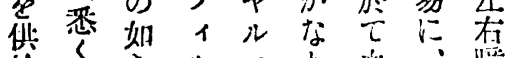

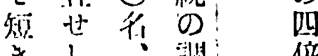

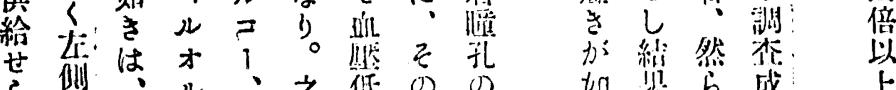

こ ら

综

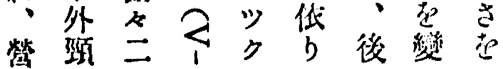

存守守有 


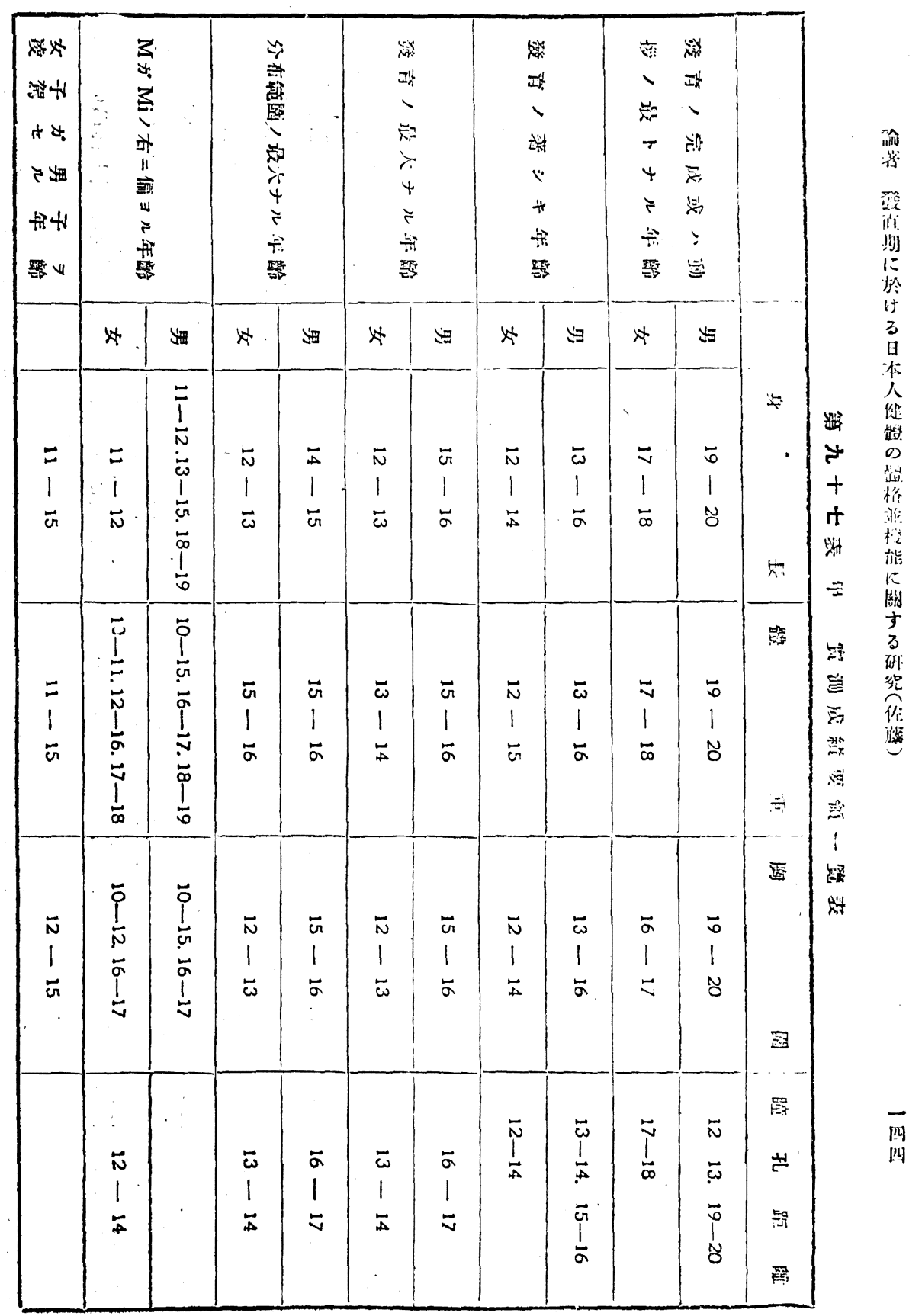




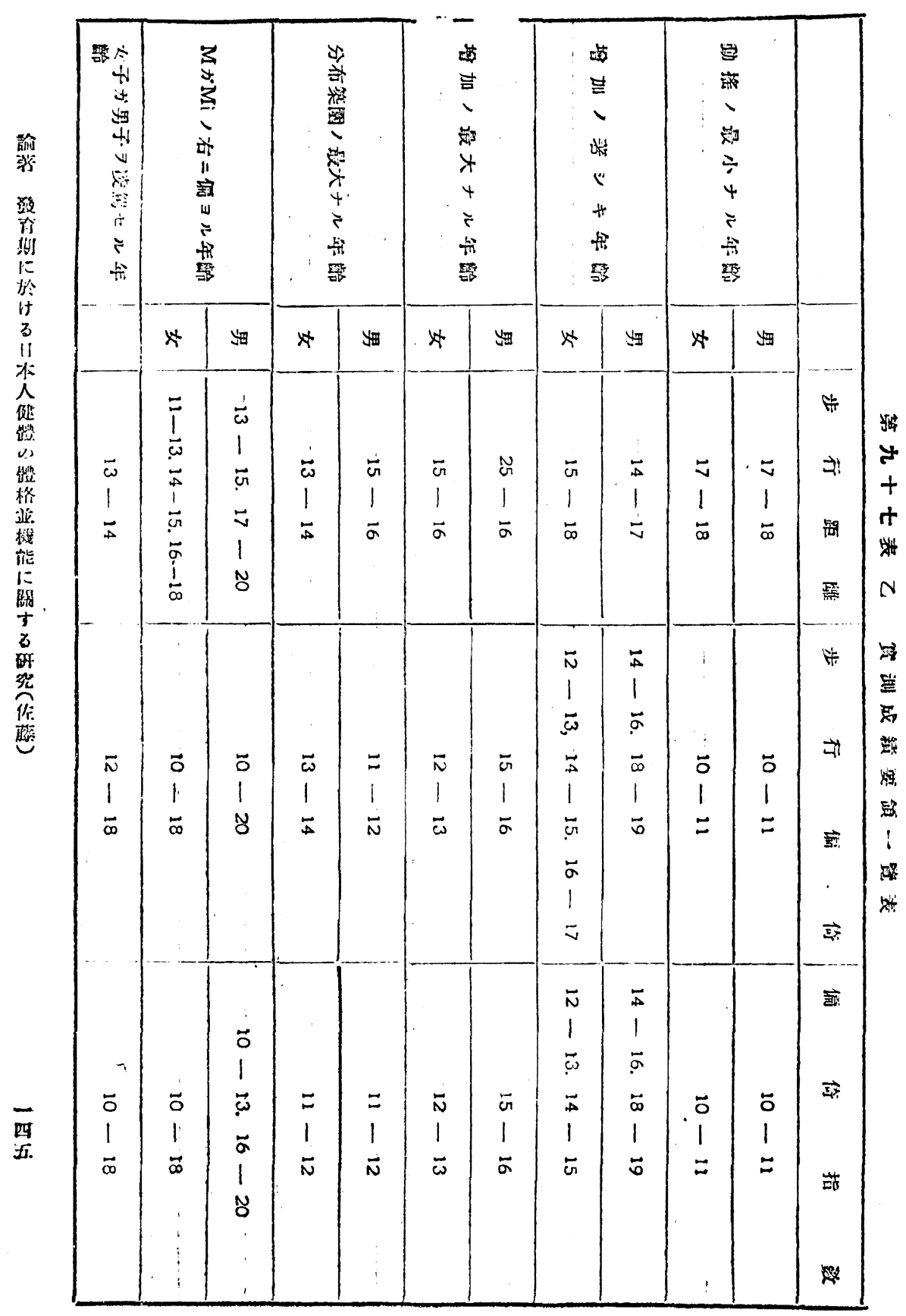




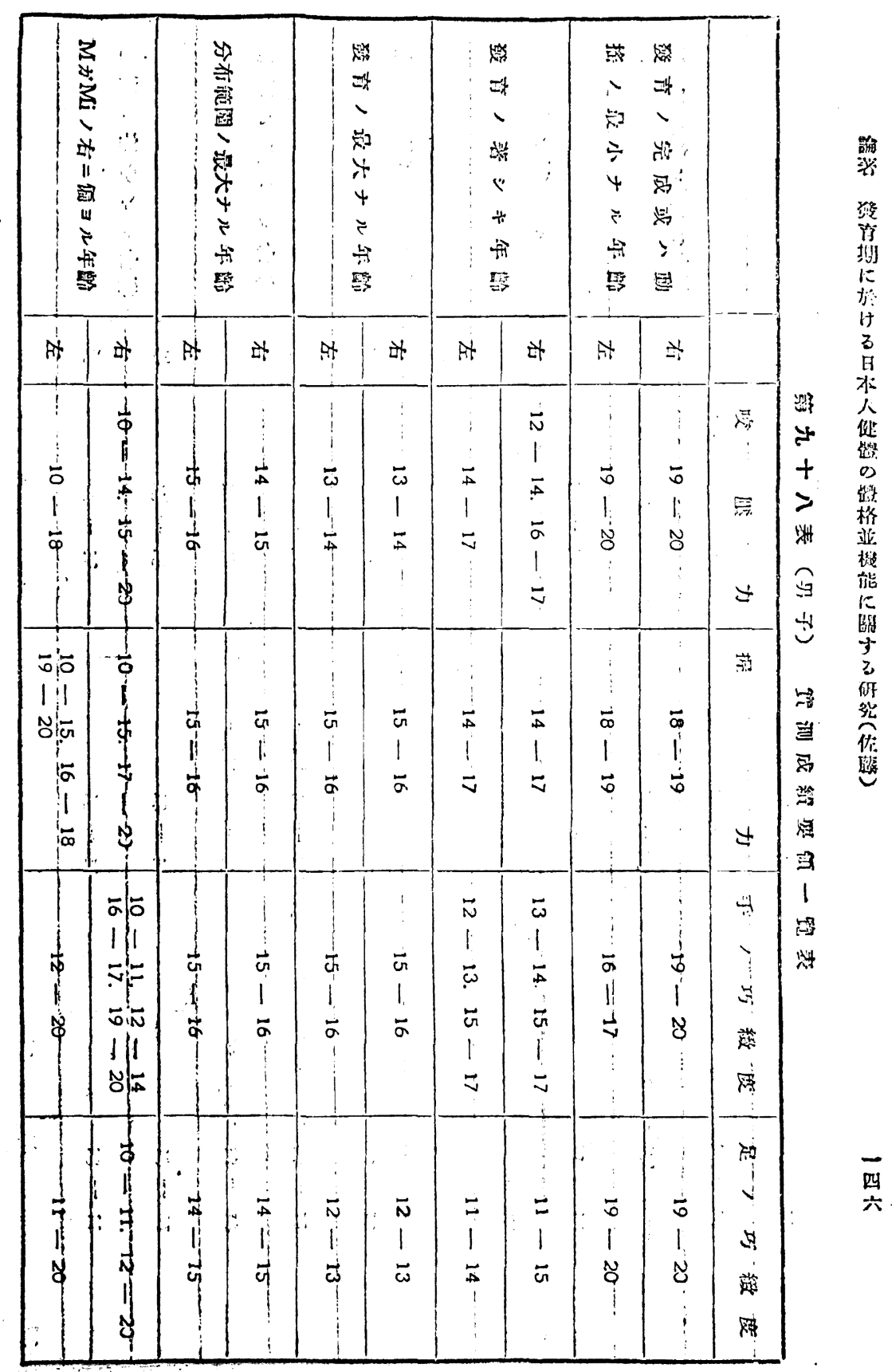




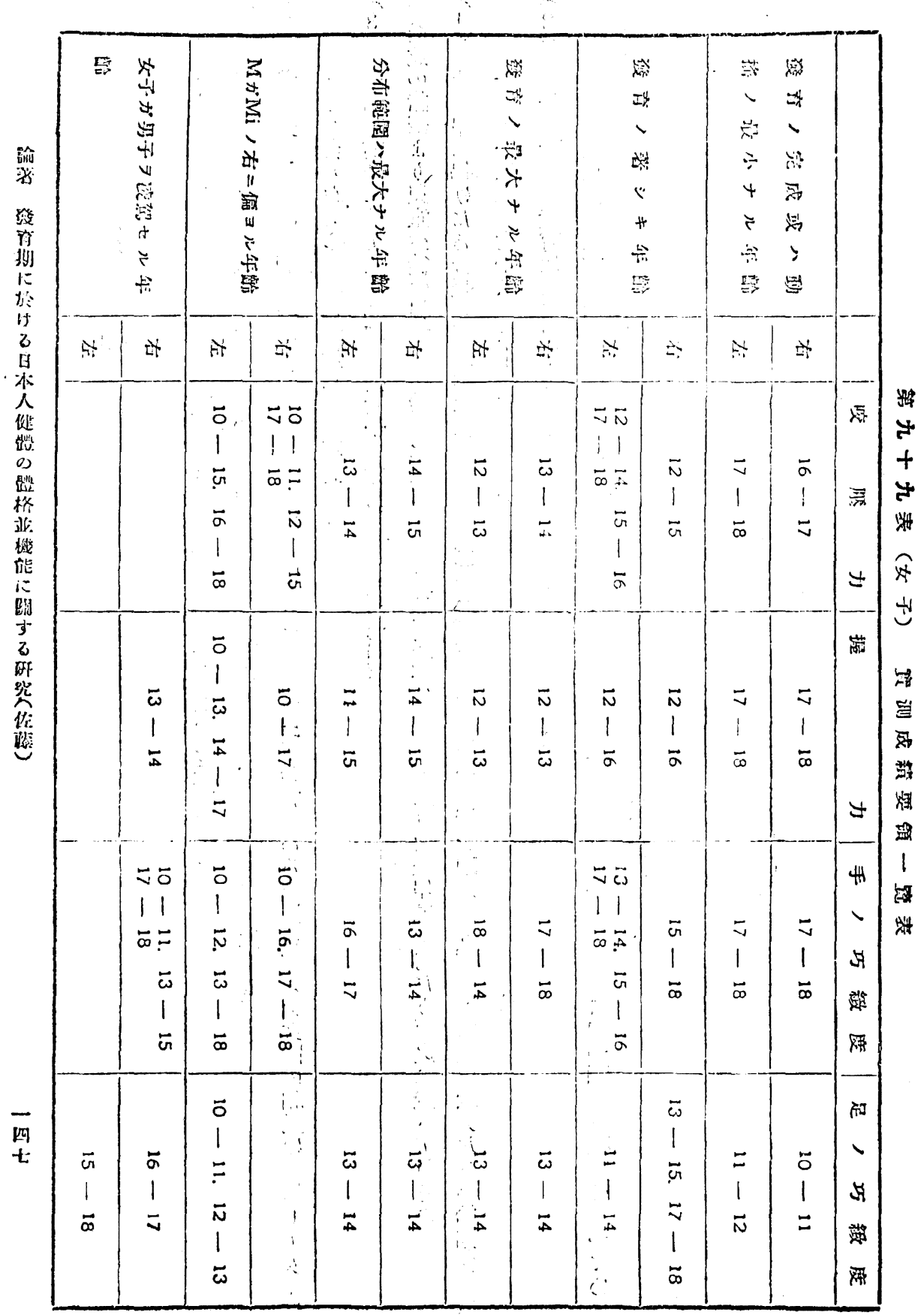




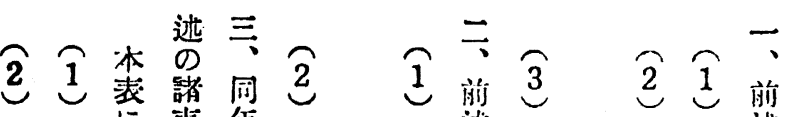

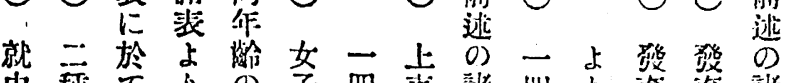

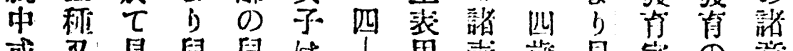

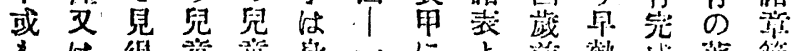

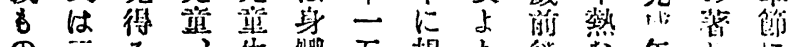

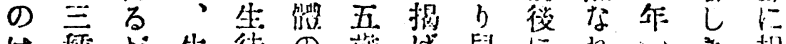

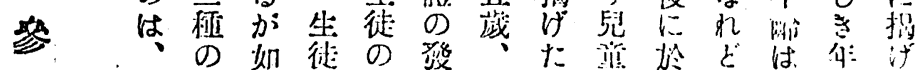

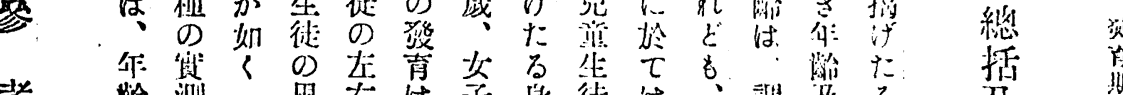

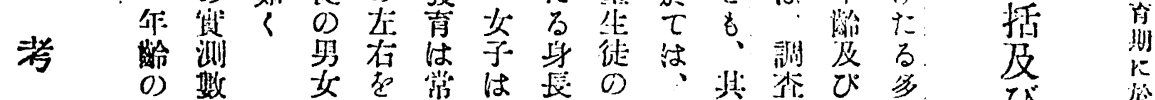

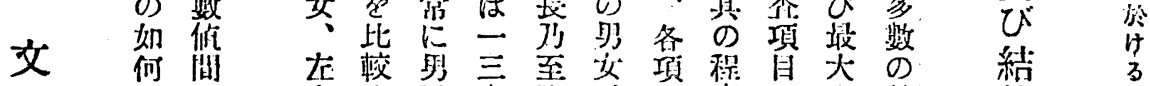

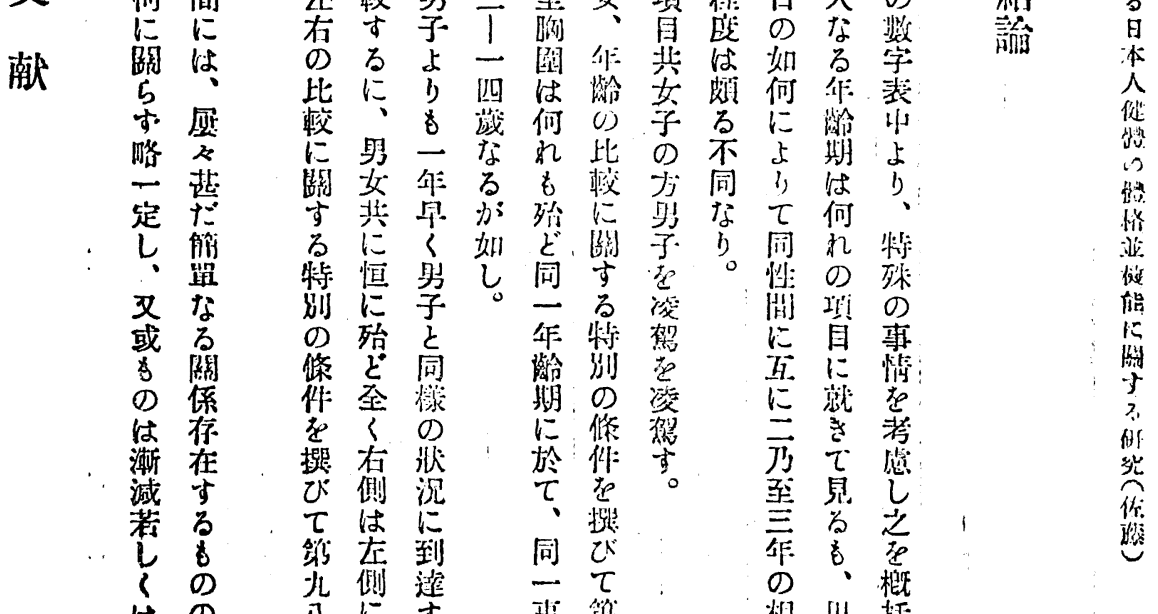

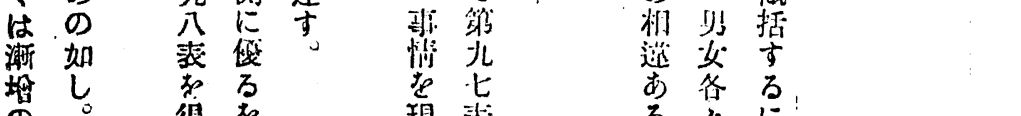

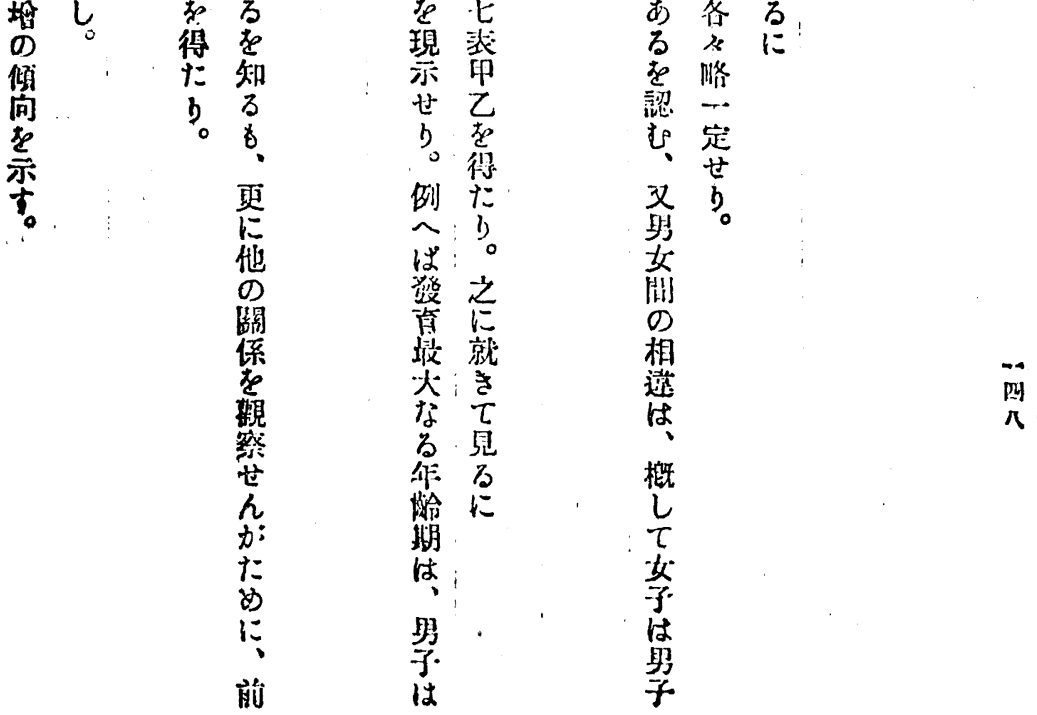




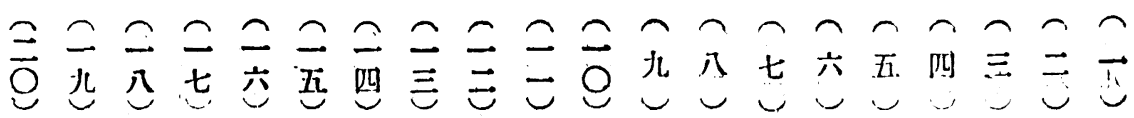

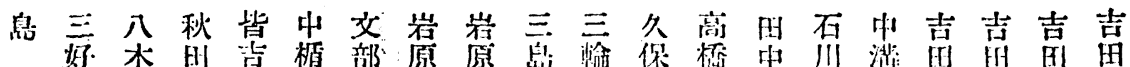

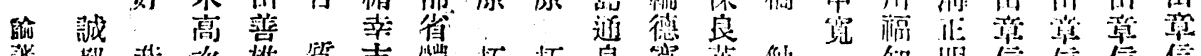

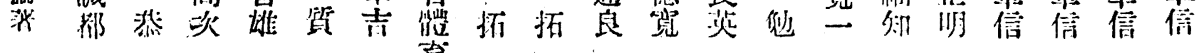

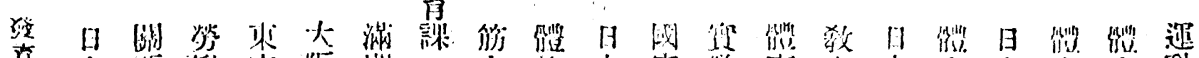

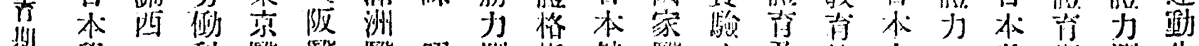

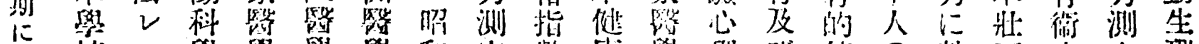
枪校

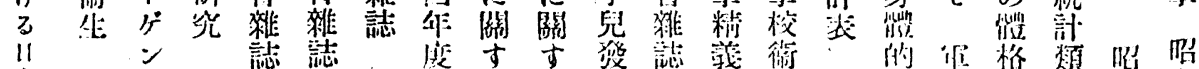

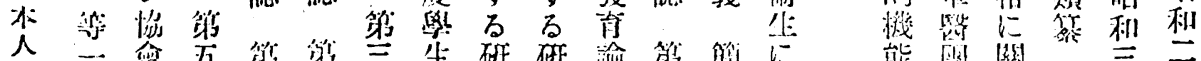

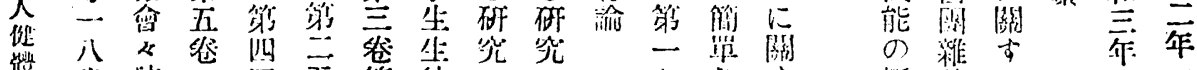

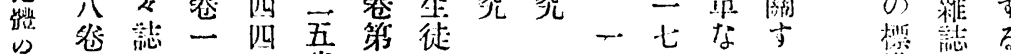

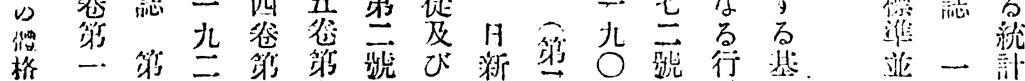

源 -

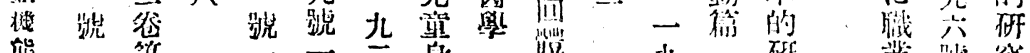

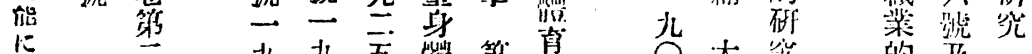

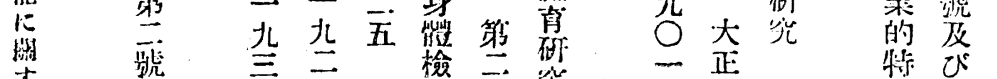

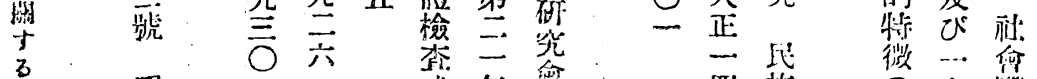

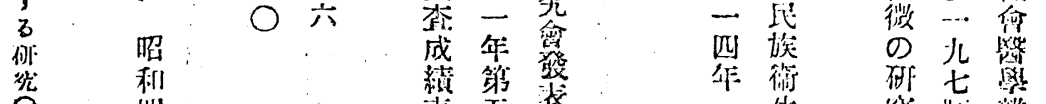

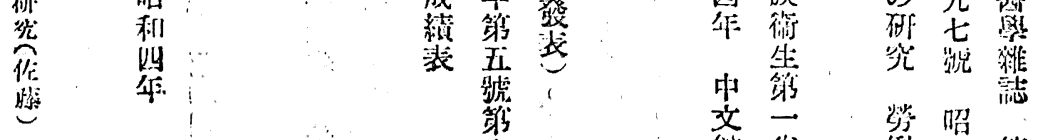

统恼倒和第

至自科㞦畑

题

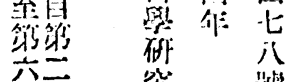

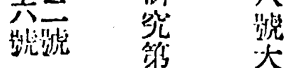

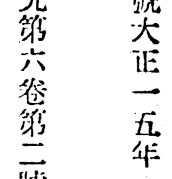




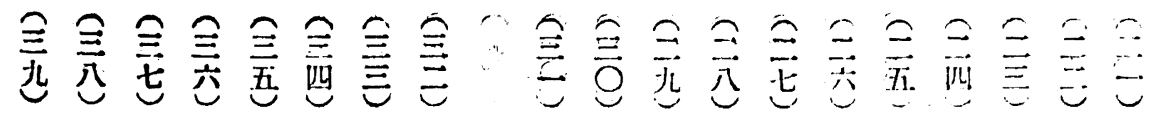

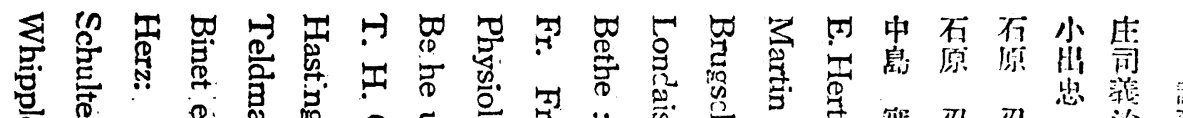

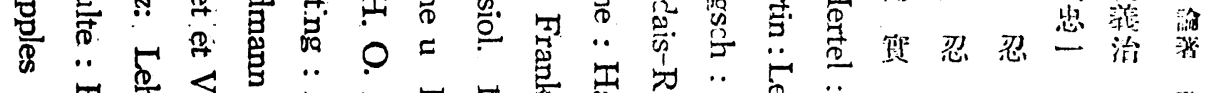

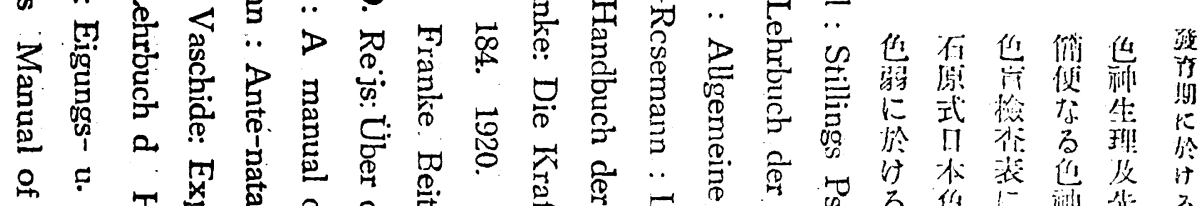

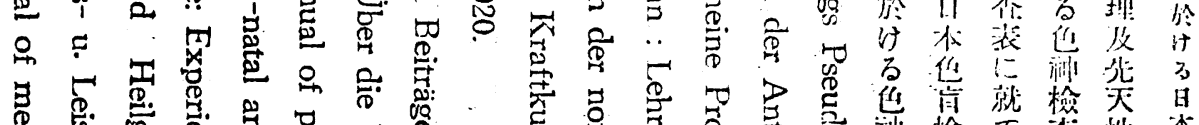

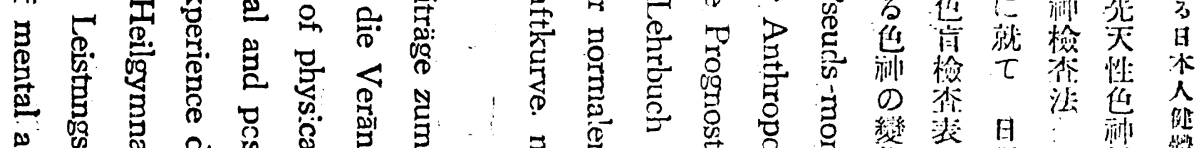

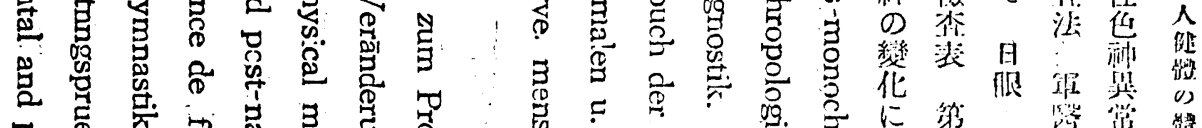

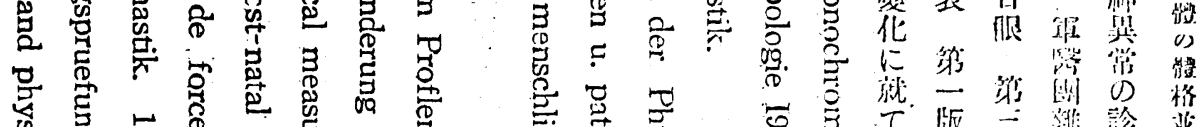

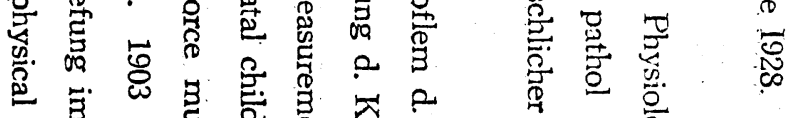

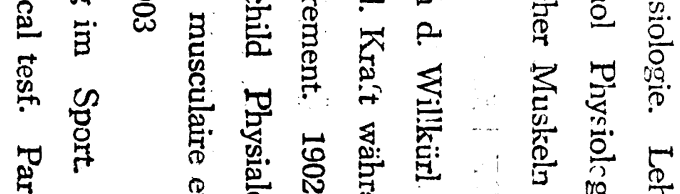

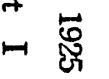

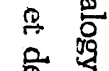

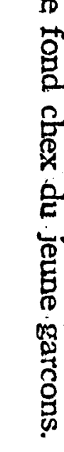

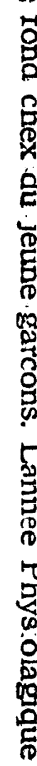

葛

然

宽

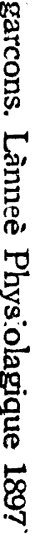

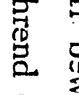

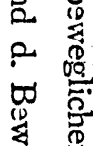

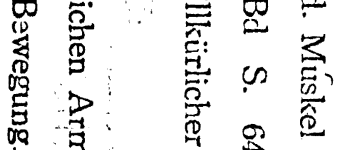

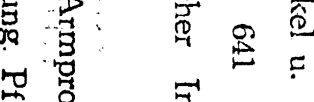

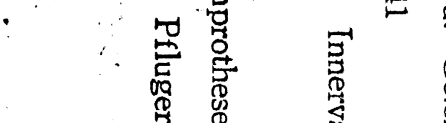

क.

总

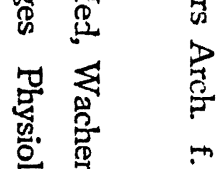

苞

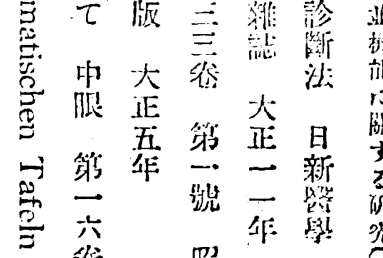

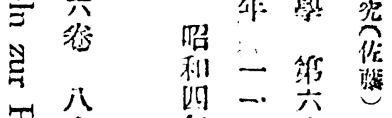

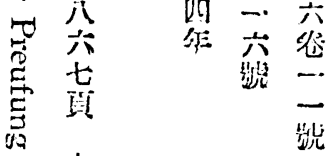

若六

䨔

空

总. 